
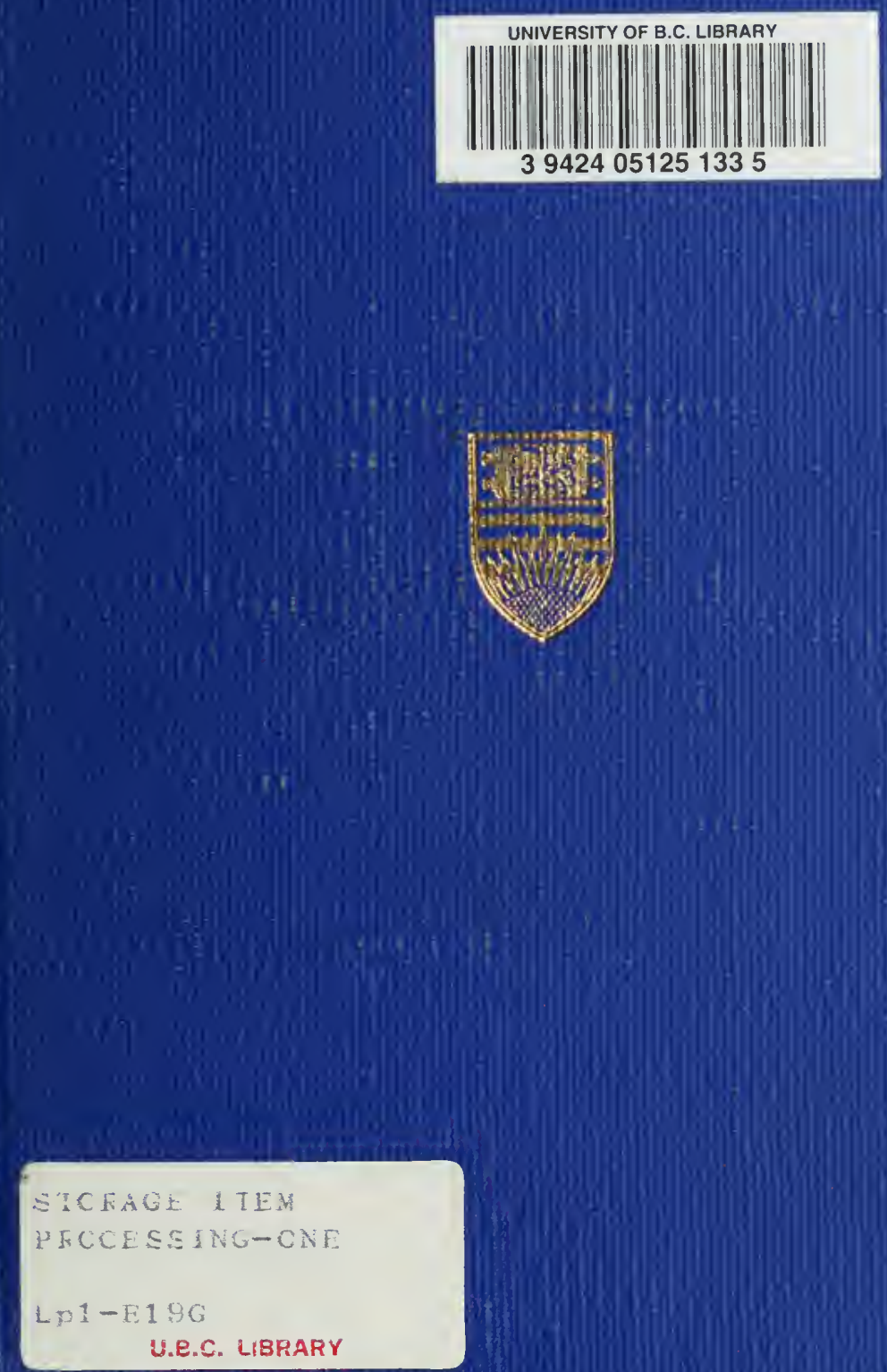


\section{THE LIBRARY}

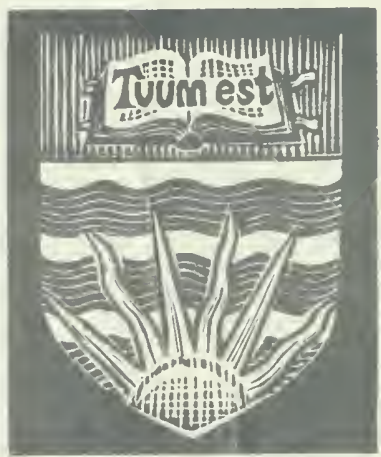

THE UNIVERSITY OF BRITISH COLUMBIA 
Digitized by the Internet Archive in 2010 with funding from University of British Columbia Library 




\section{WESTERN GRAZING GROUNDS AND FOREST RANGES}






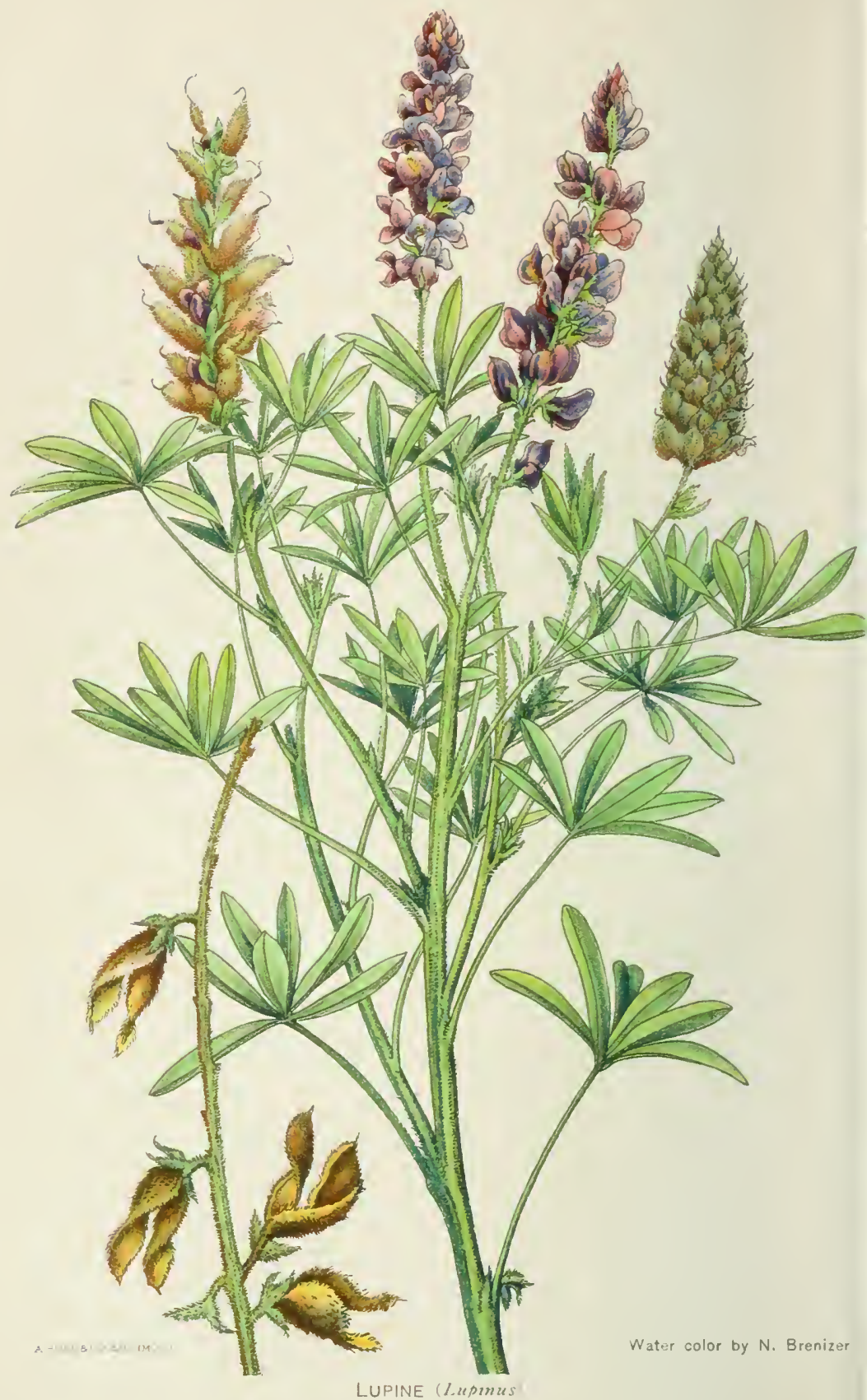




\section{Western Grazing Grounds}

Forest Ranges

A HISTORY OF THE LIVE-STOCK INDUSTRY AS CONDUCTED ON THE OPEN RANGES OF THE ARID WEST, WITH PARTICULAR REFERENCE TO THE USE NOW BEING MADE OF THE RANGES IN THE NATIONAL FORESTS

\section{BY \\ WILL C. BARNES \\ INSPECTOR OF GRAZING \\ U. S. FOREST SERVICE}

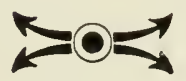

CHICAGO:

THE BREEDER'S GAZETTE

1913 
COPYRIGHT, 1913. SANDERS PUBLISHING: ( $($ ). All rights reserved. 
TO

ALBERT F. POTTER,

Associate Forester and Chief of Grazing United States Forest Service,

who, through his practical experience on the western ranges, and genius for organization, built up from the very foundation, without precedent or guide, a system of controlled grazing on the national forest ranges, that will always be a monument to his ability, judgment and foresight. 



\section{TABLE OF CONTENTS.}

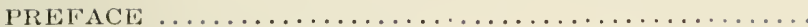

$15-19$

LIST OF BOOKS CONSULTED .................

CHAPTER I-THE EAIRY WESTEIIN IRANGE.

Early events-The genesis of the trail herds-The buffalo-The stockman's westward advance-The inevitable happens-The era of re-adjustment-Advent of the sheepmen-Range wars-A sample attack-Govel'nment control of grazing lands-Curtailment of the

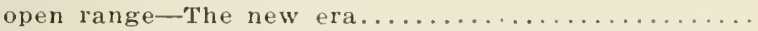

CHAPTER II-PROGIIFSS OF TIE IANNGE BUNINESS.

The southern steer trade-Southern steers in the northCurtailment of northern movement-Southern lamb trade-Grasses and forage of the southeln rangesAlfileria-Semi-desert range of the south-Higher ranges of the southwest-Southwestern grasses-Black grama grass-Sacaton-The sages-Prickly pearFeeding mistletoe-Nlountain forage-The northern desert ranges-The northern range-Features of northern range-Spring ranges-Carrying capacity of ranges -Horses the worst grazers-Range for cattle........

CHAPTEI: III-COMING OI" THE SETTLERS.

Extension of holdings-Displacing stockmen-Early settlement in the Great Plains region-The settler's' second attack on the arid region-Success of the settlers-The

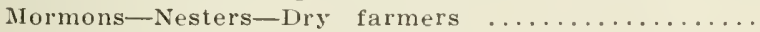

CHAPTER IV-LIVE STOCK ON THE RANGE.

Live stock in United States-Live stock in western statesShorthorns on the range-The advent of HerefordsEarly horses of the plains-stockmen's horses-Mustangs-Wrong use of names-Sheep introduced-Early shepherding-Impress of the Merino-securing mutton type-Angoras-Hogs on the ranges ............. 91-113

CHAPTER V-HANDLING CATTLE ON THE RANGE.

Number of range outfits-Past and present range conditions-Old time equipment-The bog rider-Developing water-Range methods-Herds not large--Branding the calves-Night guard duty-Brand inspectors-Loading for market-Loss of "downers"-Hay-fed cattle-Rule for measuring hay ...................... 114-139 
CHAPTEF VI-HANDLING SHEEP ON THE IRANGL.

Lamb feeding-Rise in price for lambs-Adrance in wool prices-Increase in cost of production-Grazing leased lands-Double profit from sheep-Time of shearingWeight of fleece-Dipping-Time of lambing-Lambing grounds-The herder's work-Marking-CastratingDocking-Night herding-Following the "drop band" -Lambing in tents-A critical period-Mloving to mountain pastures-Weight of lambs-Shipping the sheep-Size of bands-Bedding down at night-Sheep in fenced pastures.......................... 140-160

CHAPTER VII-GOATS ON THE RANGE.

Kids are tender-Little herding needed-Common goats breed best-Shearing and dipping...............161-163

CHAPTER VII-DETERMINING THE AGE OF STOCK.

The mouth test for cattle-Horn buttons-Fings-Age of horses-Age of sheep ............................ 1642

CHAPTER IX-RANGE STOCK MANAGEMENT.

Objections to repeated use of bed grounds-Salting stockSalt and sulphur-Kind of salt to use-Effect of excessive salt-The salt lakes-Making a salt lick-Salthungry cattle raid camps-Source of friction-Experiments with salt-Bulls on range-Number of bulls to cows-Age of usefulness-Dehorning cattle-Dehorning the calres-Value of dehorned cattle-Marking cattleFar and lip tattoo-Earmarking-Castrating-Usual methods-Keeping tab on sex-Earmarks-Brand books -Brands-Names of brands-Changing brands-Pick-

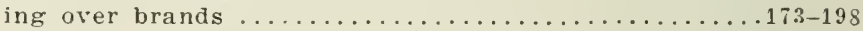

CHAPTER X-COST OF RUNNING STOCK ON RANGES.

Cost of grazing cattle-Cost with sheep-Basis of estimates -Investment necessary-Other cost factors-Cost of raising sheep-Factors equalizing costs-Tables of Tariff Board ............................. 199-207

CHAPTER XI-STOCK ON RANGES IN NATIONAL FORESTS.

T1mber the first consideration-Liberal policy followedImproving the ranges-Elimination of tramp stockmen -Tramp sheepmen in California-Changing from cattle to sheep-Cattle r's. sheey-The permit system-New settlers-The cash value of permits-Permits non-salable and non-transferable-Permits for more than one year-Drifting of stock onto forests-Fencing pririleges-Fees moderate-Possibility of competitive bidsFiesult of competitipe bids-Exchanging lands-Stock losses less-Policy of Government growing in favor...208-225 


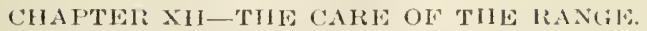

Burning off a range-Iiange erosion-Over-stocking-Suecess in handing the range-Fiestoring former range conditions-Reseeding a range-Over-grazing vs. close grazing ...........................

CHAPTEI XIII-POISONOUS PIAATS.

Ilerders should be posted-Remedies-Permanganate of potash-Poisons do not affect all animals alike-BloatLoco-Loco symptoms-liemedies-Larkspurs-Lupines -Death camas-Water hemlock-Aconite-Scrub oak -Pingue-Rubber weed-Ergot-Sneeze weed-Choke cherry-Sleepy grass-Fox tail and squirvel tail grass.246-273

CHAPTER XIV-SYMPTOMS AND HFMEDIES.

Bloat - Remedies - Loco - Femedies - Larkspurs Lupines - Camas - Water hemlock - Oaks - Ergot - Sneeze weed-Choke eherry-Pingue-kafir corn and sorghum .............................

CHAPTER XV-DISEASES OF HIVE STOCK.........28-285

CHAPTER XVI-THW DESEASES OF CATTHE.

Blackleg-Remedial measures-Texas fever-scabies or mange .................................. 303

CIAPTER XVII-DISEASES OF SHEEP.

Scabies-Remedies-Dips in use-lip and leg ulceration...304-309 CHAPTER XVIII-DISEASES OF HORSES.

Colic-Engorgenent or obstruction colic- Wind colic- $\triangle$ turia-Remedies-Snake bites-Glanders or farcy...310-319

CHAPTER XIX-INSECT PESTS.

Insect pests-Heel flies . . . . . . . . . . . . . . . $320-326$ CHAPTER XX-PREDATORY ANIAALS IN THE WEST.

Coyotes-Wild cats and lynxes-Wolves and mountain lions - Bears-Trapping and poisoning predatory animalsScents-Foisons-Prairie dogs-Poison for killing prajrie dogs ............................

CHAPTER XXI-SADDLE HORSES ON THE RANGE.

Type of horse for range work-Gaits-The American saddle

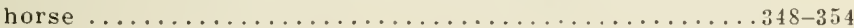

CHAPTER XXI-HORSE EQUHPMENT FOR IANGE WORK. Saddles-Bits and bridles-Blankets-Rope-Spurs and quirts-Hobbles-rack saddles-Hitches-Now for the

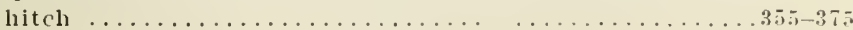

APPENDIX.

Grazing bill-A few definitions................... 


\section{ERRATA.}

Page 172. Lines 22 and 23. Read "This gives the sheep eight incisors, the same as the cow, and two more than the horse."

Page 25t. Line 20. For "paunching or rumenotomy" read "tapping."

Page 255. Line 4 and subsequent. For "cantula" read "cannula."

Page 277. Line 6. For "eight ounces of water" substitute "one to two drams of distilled water" for the hypodermic dose.

Page 279. Add to Symptoms of Ergot. "The poison in cattle acts more slowly, causing sloughing sores about the fetlock, and may induce sloughing of horns, tail or hoofs. Abortion may also be caused. These facts are perhaps a little more noticeable in the central west than in the range country, but are indicated in both regions."

Page 312. In lines 12 and 13 substitute "one dram of calomel" for "two drams." A safer dose still is raw linseed oil.

Page 313. Line 20. For "a teaspoonful of ordinary morphine or opium" read "laudanum or tincture of opium." The hypodermic dose for an adult horse is three to six grains, four grains usually sufficing. By mouth, two to ten grains is the rule. A teaspoonful of ordinary morphine or opium would prove fatal.

Page 319. At the close of line 19 insert the following: "All cases of this disease should be reported immediately to local and state authorities. State and federal laws provide for the control of the disease, but ranchmen in particular are apt to be careless relative to the observation of the law. For that reason the disease often comes from the far west." 


\section{LIST OF ILLUSTRATIONS.}

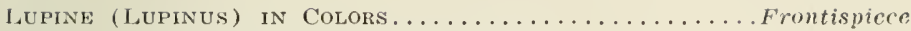

The Old Type of Texas Long-horn Steer.............. 23

The Certain Result of Oyergrazing............... 32

A Typical Southwestern Mountain Valley Range in the YeLLOW PINE REgion ....................... 37

A Desert, or Mesquite Range, Near Tucson, Ariz.......... 4]

Alfileria (Erodiun cicutarium), "Filaree" ........... 4 "

Galleta (Hilaria rigida), Pronounced Gur-et-ta......... 44

NeEdle or Dogtown Grass (Aristida longiseta) ........... 45

Buffalo Grass (Bulbilis dactyloides) . ............... 46

Curly or Creeping Mesquite (Hitaria cenchroides) ......... 47

BERMUdA Grass (CAPRIOla dactylon) ................ 4 s

Blue Grama Grass (Bouteloua oligostachya) ............ 51

Hairy Grama Grass (Bouteloua vestita) .............. 52

Black Grama grass (Muhlentergia porteri) . ............ 53

Sacaton (Sporobolus airoides), Sometimes Calded Salt Grass... 55

SWEET SAGE OR "WINTER-FAT" (EUROTIA LANATA) ......... 56

Service Berry (AMElianchier alnifolia) . . . . . . . . . . 59

Mountain Mahogany (Cercocarpus parvifolius) . . . . . . . 60

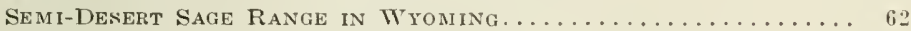

Pratrie June Grass (Kolleria cristata) . . . . . . . . . . . 67

Bluestem or Western Wheatgrass (Agropyron smithil) . . . . . 68

Mountain Bunch Grass (Festuca viridula) .............. 69

Bridges BUilt to Cross sheep OVer THE BoIse River in IdAHo

and Blach's Fork, Utah, Uinta National, Forest........ 71

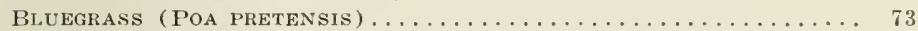

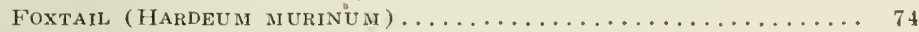

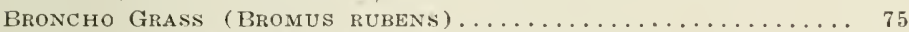

Festuca Myuros (Sometimes Called Poyerty Grass)......... 76

A Typical Western Stock Ranch (in Utah) ............ 83

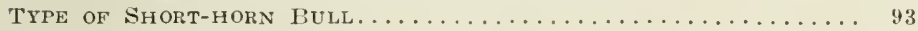

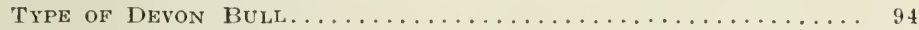

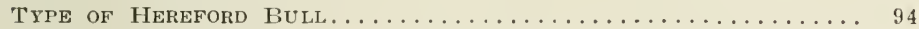

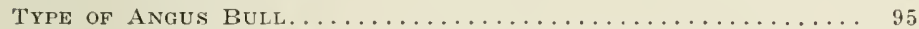

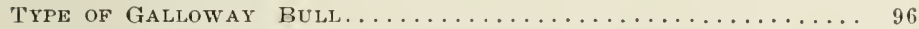

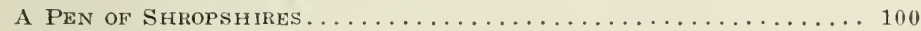

A PAIr of Lincolns.......................... 101

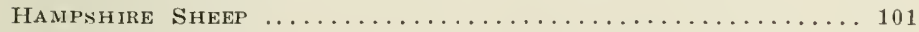

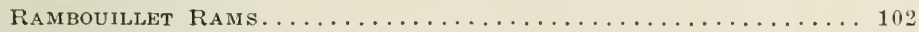

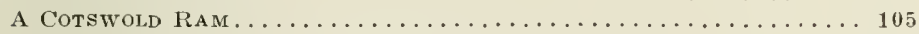

A Band of Common New Mexico Goats................. 107 
ANGORAS ON BRUSHT Hillsides in ARIZONA $10 \mathrm{~S}$

The Chaparejos With the Goat Shin Firont Are MIRE Theatri-

Cal than Practical....................... 117

The "Bog Rider" at WORK. PUlling A Cow OUt of A Bog Hole. 121

A New Mexico ROUND-UP OUTFit AND AN OLD-TIME CHUCK WAgON 124

"Stoop as You Near the Average Cow Pont."............ 125

The Cattle are Bunched in ONe Great Herd at the Round-uP

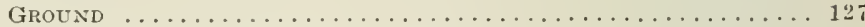

A DAY HERD . . . . . . . . . . . . . . . . . . . . . . . . .

A Round-up Outfit Branding Calves................. 129

"Thet Are Roped and Dragged to the Fire"............. 130

Putting a "Butt" Brand on a Calf................. 131

"A QUICK JERK AND THE ANIMAL LANDS UPON ITS SIDE" 132

THE "SQEeze ChUTE" FOR BRANDING AND DEHORNING.......... 133

Westeri Inspectors Examinixg Brands of SteERs. . . . . . . . 134

Yearling Steers iN Yards at Magdalena, N. M., Awaiting IN-

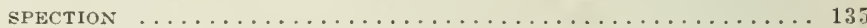

Loading Fat Steers in Colorato................. 137

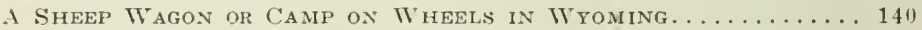

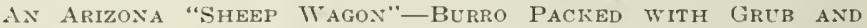

WATER ............................ 141

"AN Average Hand Shearer Will Clip 60 to 70 Sheep Per Day" 145

"The IMProved MaChines ENable a Shearer to HaNdle 200

SHEEP IN AN EIGHT-HOUR DAT" ............... 146

PENS AND YaRds IN $\Pi$ HICH SHEEP ARE DIPPED AND HANDLEd IN

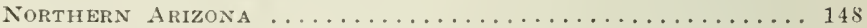

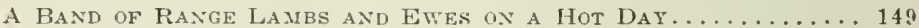

The "Galvanized Ewe" or Orphan La.nBs Artificially Fed ... 150

A LAMBing Tent IN OREgon. . . . . . . . . . . . . . . . 153

In Heavy Timber "Clts" May OcCur. And the Band Should Not

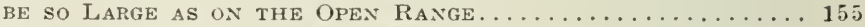

A Herder Can look after Many More Sheep on an Open Range

THAN ON A Broken Range.................. 157

A CoYote-Proof Fence IN THE WALLOWA MOLNTAINS. BuILT BY

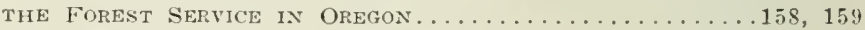

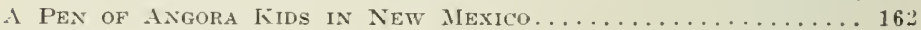

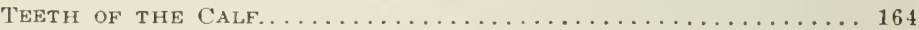

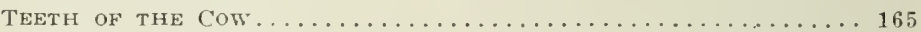

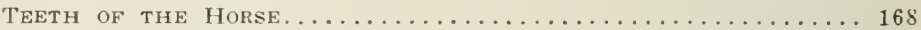

TEETH OF THE SHEEP. . . . . . . . . . . . . . . . . .

"Hog TiEd"-A Horse Tied Down For Branding or DOCTORING.. 182

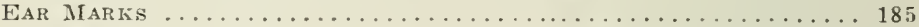

Brand Books.................

Brands . . . . . . . . . . . . . . . . 19. 194, 196, 197

"Down These Trails the Water Fixally TORE" ........... 228

OLd Stocli Trail.s Washed OLt, Forming Arroyos iN MEAdow

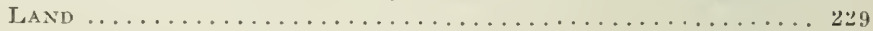

IN Arizona Range After a Hard Sprtig. . . . . . . . . . 231

A RANGE OF "SNAKE" OR "FIRE" WEed WHICH IS SOMETIMES MIS-

TAKEN FOR FEED 
ORCHARD GRASS (DACTYLIS GLOMERATA) ............... 23!)

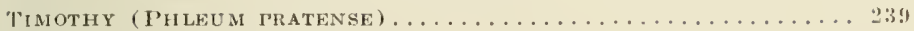

RED Top (AgRostes AlBA) . . . . . . . . . . . . . . . . . 240

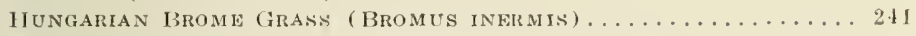

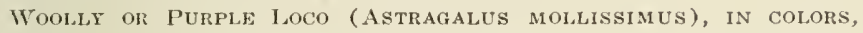

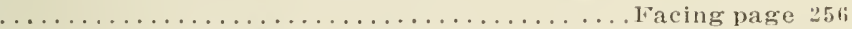

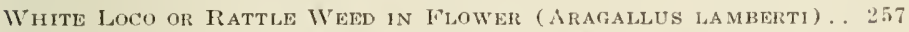
I Joco on the Range Near Albuqtigrque, N. M. . . . . . . . . . . 258 A LOCOED ANIMAL WILL STEP HIGH OVER ANFTHING IVEN A Rope

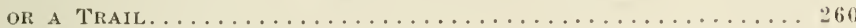

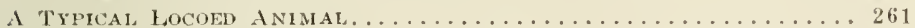
PURPle IAARSPUR (DRLPHINIUM Blcolor), IN Colors . lacing page 264 DEATH CAMAS ( $/$ YGadent's venenosus), in COLORS ... Facing page 266 IVATER IIEMLOCCK (CICUTA VAGANS), IN COLORS . . . . Facing page 267 ACONITE (ACONITUM COLUMBIANUM), MONK'S IIOOD, IN COLORS.

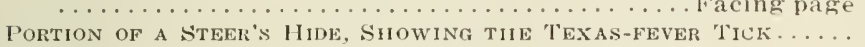

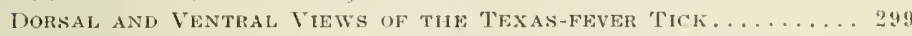

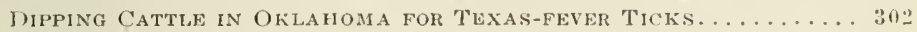
AFter BeING DIPPed, tile SheEp Pass Through a Dripping PliN

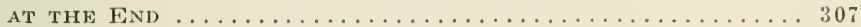
THE HEEL FLY (HYPORDERMA LINEATA) . . . . . . . . . . . . 322

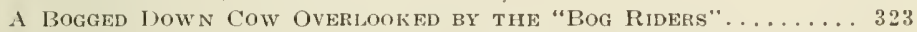
THE CAMP OF TWO GOVERNMENT IIUNTERS IN THF BOISW NATIONAL

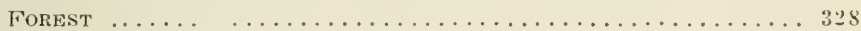
A Coyote in a Trar............................ 329

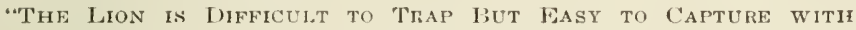

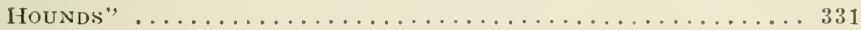

A Prairie dog Mound in an Alfalfa Field................ 341

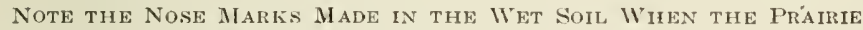
Dogs RePAir Their Mound. ...................... 341

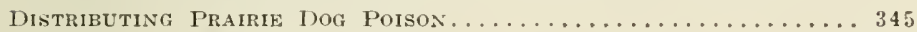

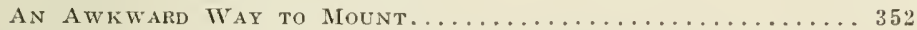

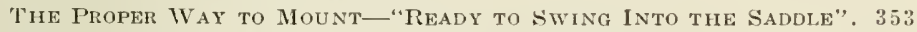
The Low Hote Texas Tree, Weight, to Pounds........... 355

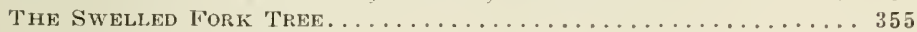

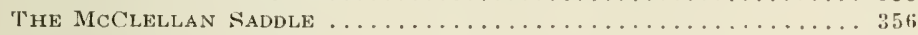

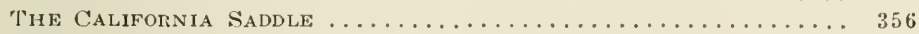

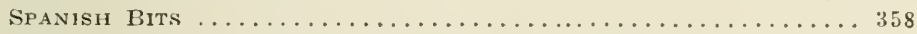

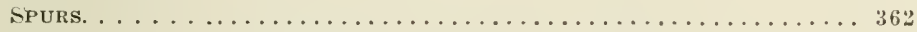

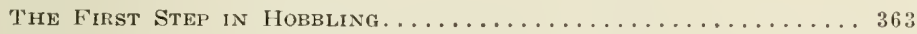

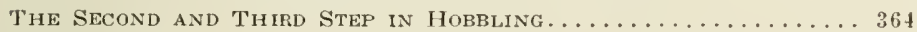

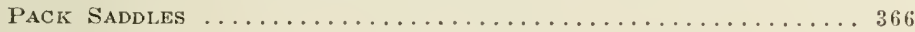

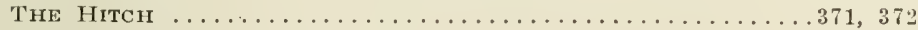

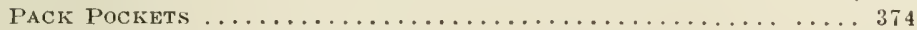

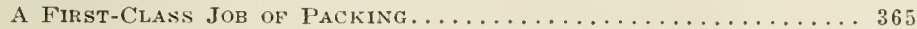

Packing Down a Mountain Side...................... 36 .

A Mandy Bed Pach, Sometimes Called the "Oregon Wind"... . 369 



\section{PREFACE.}

Every author believes that the book which he is placing before the public will "fill a long-felt want," and success or failure depends very much on how closely he has been able to gauge the nature of the "long-felt want." In writing this book, I have had in view the demand for some practical work on the grazing side of their profession by the young men who are entering or preparing to enter the Forest Service of the United States.

The science of forestry is a new one to the most of us, and the conditions here are so very different from those in older countries, where it has been studied for many years, that we are forced to meet and solve many new problems for which there are no precedents or established rules. Among the most perplexing questions which the student of forestry must cope with here is that of utilizing the area included in the National Forests so as to get for the people the full value of all its resources. One of the greatest of these resources is the feed and forage which will furnish sustenance for millions of cattle, horses and sheep. Like the "wheel that will not turn with the water that has passed," this feed must be used as it grows each season or be forever wasted. It cannot be stored or saved for future use.

From the first settlement of this country the pioneers have used the vacant lands about them for grazing their stock with little or no supervision or restraint, and no 
scheme which presumes to lock up these grazing areas against the coming of the settlers' herds will ever meet with the approval of the American people. It is true we must have trees and lumber, but we must first of all be fed, and the meat-producing powers of the grasses growing on these forested areas are entirely too valuable to be overlooked or ignored. Therefore it is well that this has been recognized at the beginning of our forestry work, and careful plans laid to utilize every spear of grass and bit of forage where it may be done without defeating the original purpose of establishing the National Forests.

Heretofore those handling the grazing side of this work have been drawn from that class of men who have all their lives been identified with stockraisingpractical men accustomed to the range and understanding the needs of stockmen from a utilitarian rather than a scientific standpoint. But this source of supply cannot always be depended upon. The author believes the two matters go hand in hand, and that there is room for the trained forester and the trained grazing man on the same platform. Scientific as well as practical forestry demands men educated especially for the work, and the young fellows who are graduating from our forestry schools will eventually fill the places on the forests now held by graduates from the western school of "hard knocks," the course of which, for most of them, covered many long and weary years before they received their diplomas.

These young graduates cannot of course have any great knowledge of the practical side of the stockman's work, because so much of it must be learned from actual experience and every-day life on the ranges. Never- 
theless the author believes it possible to put the experience of thirty years' handling live stock on the open ranges under all sorts of conditions into a book that will be of some practical use and benefit to these students and others engaged in the work. So far as possible, I have endeavored to write things down from the practical point of view, and to put them in language that would not smother their meaning in a haze of scientific or professional expressions.

The chapters on poisonous plants and range grasses will, I trust, be found of value, not only to the forest man but to the stockman. In my experience I have found few stocknen who conld identify by their proper names even the commonest grasses on their ranges or the various plants poisonous to stock, and I hope that the illustrations and plates scattered through the work will furnish a means of identifying them that will make the book of value for that, if nothing more. It is possible that the trained botanist will find errors in my classification of some of the plants. I have made every effort to check up each one of them and make certain they were correct, but in several instances I found that the scientists themselves did not all agree as to their proper names.

In the chapter on diseases of animals I have only tried to show the plainest symptoms of the ordinary discases that affect live stock as they appear to a stockman and not a veterinarian. It is of course impossible to have a veterinarian at hand for every sickness that the stockman finds among his domestic animals, and it is to cover these emergency cases that I have written. Most of the remedies are those to be found in every stock-owner's cabin, and if not they should be there. To the forest ranger, out in the hills with his saddle 
horses and possibly a milk cow or two, I deemed this information of unusual value, because of his isolation and dependence upon his own efforts to relieve the suffering animal. Most of these remedies have been tried by myself or used by others under my own observation.

In handling the various sections of the country in regard to the ranges it has not been possible to cover every state, but I have taken some specific well-known range and-let it answer for that region as a whole. Doubtless many readers will wonder why such and such a plant or bush, prominent on his immediate range, has not been mentioned. Recause of lack of room, many forage plants and grasses have been onitted, but I believe those which have been included are the species most generally found through the range country, and it was out of the question to mention them all. In running down the local names for many grasses and browse I have found different names for the same plant very common. Buck brush in California is not the buck brush of either Arizona or Montana, while there are as many different kinds of bunch grasses as there are states in the West.

The chapter covering saddle horses, saddle equipment and packing is for the benefit of the beginner who may want some information on these subjects as a guide to his investments in such things.

The author desires to acknowledge his indebtedness to many friends for advice on matters connected with the work, and especially to Mr. Frederick Coville, Dr. A. S. Hitchcock, Dr. R. H. True and C. D. Marsh of the Bureau of Plant Industry and James T. Jardine of the Forest Service, whose kind suggestions upon matters on which they are so well posted has been of great benefit. 
I have also received much assistance which I desire frankly and gratefully to acknowledge, from the many Government publications written by such well-known authorities as David Griffiths, F. Lamson-Scribner, V. K. Chestnut, E. V. Wilcox, Dr. C. Hart Merriam, Vernon Bailey, James T. Jardine, Richard WV. Hickman, D. E. Salmon, Herbert T. Osborn, C. D. Marsh and others, who are always so reliable and thorough in their investigative work. In identifying the various plants and grasses the work "American Grasses," by F. LamsonScribner, constituting Division of Agrostology Bulletins Nos. 7, 9, 17 and 20, has been of the greatest assistance and frequently consulted.

The labor involved in getting together the material for this volume has been considerable, but the pleasure derived and the information gained, made it indeed a labor of love and well worth while. If the book is of use to the young men who are taking up forestry as their life-work, in assisting them to a better understanding of some of the many problems which they will meet in handling grazing matters upon the forests, or to stockmen themselves in managing their herds, the writer will feel well repaid for his work.

\section{IVILL C. BARNES.}

Wrashington, D. C., July, 1913. 


\section{LIST OF BOOKS CONSLLTED.}

The author gladly acknowledges his indebtedness to the writers of the following publications, among the many others which he has consulted in getting together the material for this book:

"American Grasses," Buls. 7, 9, 17 and 20, Division of Agrostology. Department of Agriculture; F. Lamson-Scribner.

"A Protected Stock Range in Arizona," Bul. 177, Bureau of Plant Industry, Department of Agriculture; David Griffiths.

"Cofote Proof Pasture Experianent," Cir. 160, Forest Service, Department of Agriculture; J. T. Jardine.

"Destruction of Wrolves AND Coyotes," Cir. 63, Bureau of Biological Survey; Vernon Bailey.

“Diseases of Cattle," Issued by Department of Agriculture.

"Diseases of Horses," Issued by Department of Agriculture.

"Foregt Trees of THE PACific Slope," G. B. Sudworth.

"Insects Affecting Domestic Animals," Bul. 5, New Series, Division of Entomology, Department of Agriculture; Herbert Osborn.

“Loco Disease of The Plains," Bul. 112, Bureau of Animal Industry; C. D. Marsh.

"Methods of Eradicating Cattle Ticks," Cir. 110, Bureau of Animal Industry ; L. A. Klein.

“Pasturage Systey for Handling Range Sheep," Cir. 17S, Forest Service; J. T. Jardine.

"Principal Poisonous Plants of the United Sitates," Bul. 20, Division of Botany, Department of Agriculture.

“Scabies of CAtTle," Farmers' Bul. 152; Richard W. Hickman.

“SCAB IN Sheep," Farmers' Bul. 159; D. E. Salmon and C. TV. Stlles.

"Some Poisonous Plants of the Northern Stock Ranges," Yearbook, Department of Agriculture, 1900; V. K. Chestnut.

“Stocis Poisoning Plants of Montana," Bul. 26, Division of Botany, Department of Agriculture; V. K. Chestnut and E. V. Wilcox.

“Texas or Tick Fever and Its Prevention," Falmers' Bul. 258 ; Joln R. Mohler.

"The Larkspurs as Poisonous Plants," Bul. 111, Part 1, Bureall of Plant Industry; G. H. Crawford.

"The Prairie Dog of the Great Plains," Yearbook, Department of Agriculture, 1901; C. Hart Merrian.

"The Red Desert of Wroming," Bul. 13, Division of Agrostology, $\overrightarrow{\mathrm{De}}$ partment of Agriculture; Aven Nelson.

“Thirty Poisonous Plants of The United S'tates," Farmers' Bul. SG; Chestnut. 


\section{THE EARLY WESTERN RANGE.}

From the time of the Pilgrim Fathers down to the present day one of the greatest resources of the United States has been the natural grasses and forage plants upon which millions of domestic animals are annually supported. Owing to the nature of the grasses and herbage, the business of the grazier was not developed in the eastern portion of the United States to the same extent as in the states lying west of the Missouri River.

The climatic conditions in the eastern states made it impossible to utilize the grasses all the year round, except by harvesting them and storing the crop away for winter use.

In the more arid sections west of the Missouri, known as the region of the Great American Desert, are found grasses that cure on the ground in the pure dry air, while a shortage of rainfall allows them to lie on the ground without serious deterioration. Here in this desert country are also found the great family of the sages and many other forage plants of more or less value known as "browse" the "eha-mí-za" of the Spanish herders.

Early Events.-As early as 1800, before the tide of settlers had crossed the summit of the Alleghanies, the Spanish had established themselves on the far west coast from San Diego north, and their herds of cattle, 
sheep and horses covered the ranges in great numbers. In 1834, according to Dana in his "Two Years Before the Mast," a single trading vessel picked up in one trip no less than 40,000 steer hides at three California ports, San Diego, Monterey and Santa Barbara. Little effort was made by these early graziers to grow feed for their animals. They simply allowed them to scatter over the hills and plains of the Pacific Slope where the unlimited ranges afforded plenty of feed to meet all increase without danger of overstocking.

With the gradual settlement of the coast country, due to the rush of gold seekers, and the increase in the herds, the owners began to crowd over the summit of the Sierras with their stock into Nevada and across deserts and mountains into Arizona. While this easterly movement was taking place on the western slope, the hardy pioneers from the eastern part of the United States were pressing slowly out across the Mississippi River. They passed through Missouri and across the Missouri River into Kansas, where on those great sweeping plains the tide spread out fan-shape, working slowly and steadily westward. To the northwest they drifted through the states of Minnesota, the Dakotas and Montana; to the southwest through what is now Oklahoma, across the staked plains of Texas to western Kansas and to Colorado. Another stream flowed in the track of the Mormon expedition, which in 1847 blazed the trail across the plains in an almost due westerly course through the center of the then trackless and practically unknown American Desert until Utah was reached.

The Genesis of the Trail Herds.-Probably the cradle of the range grazing business was in the great state of Texas, where the raising of cattle and horses, and later 
sheep, on the wonderfully grassed plains that stretched for unbroken leagues wherever une went, was undertaken on a business hasis. liy the time the first $\mathrm{Pa}$ cific railroads began to work their way across the Kansas prairies, Texas had increased her herds until there was a glut of stock all orer the state and it was almost wortliless because of the lack of a market.

In 1867 began the movement to relieve the Texas ranges of their surplus cattle ly establishing those great

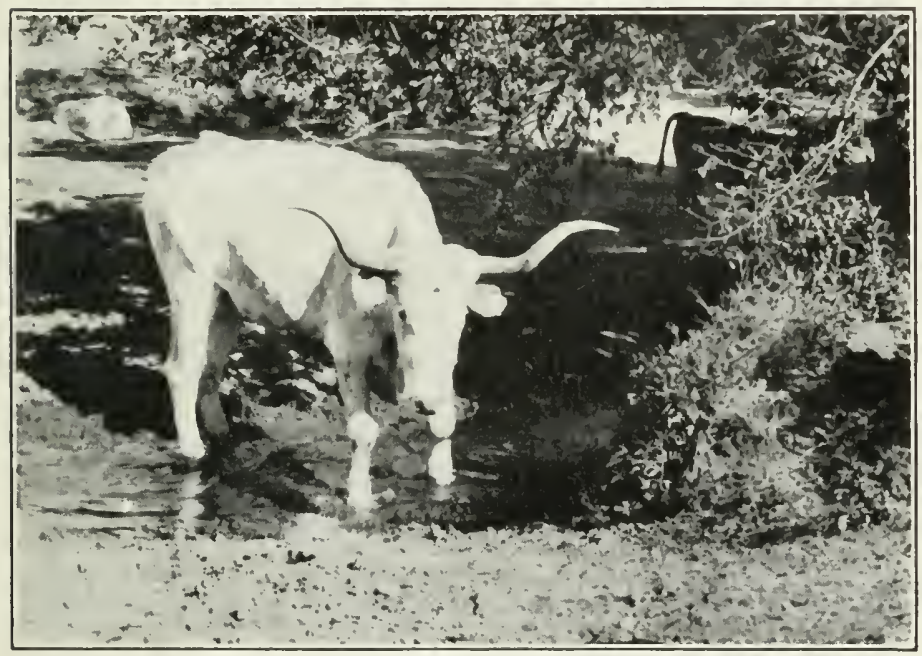

The Old Type of Texas Long-horn Steer.

trails from the south up through the staked plains, across the Indian Territory into Kansas. There they met the iron horse and found an opening to the eastern markets. Thousands of long-horned steers grazed their way over the grassy plains, starting in the early spring from the southern ranges. There was no hurry and no 
crowding of the animals; they slowly fed their way to market, gaining flesh with every day's drive, seldom making more than eight or ten miles a day and arriving at their journey's end almost ready for beef.

As the railroads forged westward the tide of emigration followed. Farms were taken up; lonely stations grew into towns and cities, and the cattlemen, seeking constantly the unfenced open ranges and fresh feed for the herds, moved westward with the end of the road.

The Buffalo.--The first Pacific railroad, with its line of settlements, acted like a wedge in splitting the great herd of buffaloes that covered the country in the early days in almost countless numbers. Gradually their annual migrations from the north to the south and back again ceased wntil there were two distinct buffalo herds: a northern and a southern. Each was gradually exterminated through many causes, the chief of which doubtless was the wanton and incomprehensible lust of civilized man for killing.

However, in the final analysis it was simply the survival of the fittest, and the cattle and sheep belonging to the settlers were far more valuable as meat producers than the buffaloes.

The Stockman's Westward Advance.-In the latter part of the 70 's the West awoke to the opportunities offered for raising cattle and sheep upon the open ranges that lay west of the Missouri River, from the Mexican to the Canadian line. Great cattle companies were formed in the East and also in Europe, whose promoters went into Texas and bought thousands of long-horned cattle and moved them north onto the vacant ranges. Millions were invested in the enterprise and for a few years millions were made, principally in speculation, promotion, and on paper. 
The stockmen of the Vest were a prodigal as well as a restless lot. With an alnost unlimited world in front of them they resented the crowding that began to develop, and there was a constant pusling forward further and further out into the prairies. They disputed with the Indian and the buffalo for the occupancy of the land, with the result that always follows where the white man comes. The red man, and his friend the buffalo, slowly melted away and eventually the advance guard from the far eastern coast met the tide of pioneers from the west coast. In the Southwest they met along the Rio Grande in New Mexico and Colorado, while to the Northuest those that crowded over the Cascades in Oregon and Vashington met the advancing tide from the East pouring over the backlone of the Rockies, andthe frontier was no more.

The Inevitable Happens.- Not an acre of the land was left unoceupied, and ranges that for permanent and regular use would have been overstocked with a cow to every 100 acres were loaded until they were carrying one to every ten. Into western Kansas. Nebraska, eastern Colorado, ont into the Red Desert country of Wyoming and Ltah, up across Montana and the two Dakotas clear to the Canadian line, they pressed in their mad search for grass. No one provided any feed for the winter, the owners preferring to risk the losses. Gradually the native grasses disappeared. As fast as a blade of grass slowed above the ground some hungry animal gnawed it off. A few men sounded a note of alarm, but the most of the owners declined to realize the approaching disaster and drifted along in their fancied opulence.

Then came the inevitable. The winter of 1886 saw 
the almost total extinction of the industry in the northwestern states. Thousands of cattle went into that winter never to see the spring flowers again. Great cattle companies with managers riding back and forth to the frontier towns in coaches and six, drawing princely salaries for doing nothing, went out of existence. Millions of dollars were lost beyond hope of recovery. A few years later, in 1893, the Southwest went through the same experience, and still greater losses were piled up against the industry.

The Era of Readjustment.-Then there was a gradual readjustment of the business. Many of the great companies operating on borrowed money went to the wall, and the remnants of their herds were bought up by men whose faith in the business still was strong. From that time to this the business of raising cattle upon the open ranges has been a fluctuating one. Man's greed to obtain something for nothing has never yet been able to content itself with a moderate profit. Each man looked upon the grass of the range as something which he must grab before anyone else could reach it. Hence the grasses were given no chance to grow, and a few good years were followed by a bad one which wiped out all the profits. What the winter storms did not kill the "bog holes" caught in the spring.

The Advent of the Sheepman.-Along in the early '90's the sheepmen began to gain a foothold on the ranges, especially in the northwestern states. Gradually they forced the cows back from their old ranges, and many long-headed cowmen in sheer self-defence turned their cattle into sheep and joined the ranks of the wool-growers. The sheepman was much more able to cope with the elements than was the cattleman. He 
had his herd under his eye at all times, and could move it to better feed before the animals becane too weak to travel. He also found out much earlier than did the cattleman that buying feed against a hard winter was money well invested.

In many ways the sheepmen profited by the bitter experience of the cattlemen, and avoided many of their pitfalls. Thus the ranges were divided and in many of the states. especially ' $W$ yoming, Montana and Idaho, the sheepmen gradually forced the cattle interests into the background.

Range Wars.-Bitter range wars followed. All over the Rocky Mountain region the conflicts between the two interests have cost many lives, both lnuman and animal, together with great financial losses. Dead-lines were drawn by the cattlemen across which no sheepman could cross with his herd and not pay dearly for his temerity.

In Arizona the Tonto Basin war waged for three years and cost more than thirty lives, besides keeping a whole country in a state of terror in the meantime. In western Colorado, especially in Routt county, the conflict between the sheepmen and cattlemen over the use of the ranges has been a serious menace to both sides. In the Blue Mountains of Oregon thousands of sheep were killed by irate cattlemen, and in the Green River district of Wyoming there have been frequent wholesale slaughterings of sheep.

The sheepmen in turn swept across the ranges occupied by cattle, leaving a wide swath as clean of vegetation as if a fire had passed over it. Fierce conflicts followed such action. Herders were killed, camps raided or "shot up" and the sheep were taken from the herders 
and scattered to the four winds a prey to coyotes. On one occasion several thousand were forced into a strean full of quicksands and boggy places, in which hundreds stuck and died like flies on sticky fly-paper. Saltpetre was scattered plentifully over salting grounds used by the cattle, which the salt-hungry sheep eagerly sought, and the saltpetre, harmless to the cattle, killed many sheep.

A Sample Attack.-Once in northern Arizona ten bands of sheep, each with about 2,500 head, had swept across the ranges along the little Colorado River, harassed by the cattlemen every foot of the way. But with an armed force of forty or fifty men as a guard, they were never seriously checked in their westward march. One night the whole outfit camped in one of the beautiful open parks under the shadow of the San Francisco peaks. The ten bands were bedded down in peace and quiet, when a hundred or more range horses, wild as deer, were driven among them, followed by fifteen or twenty cowboys whose yells and shots from their sixshooters sent the half-crazed horses down onto the sheep like a cyclone.

The horses had been previously placed in a corral, and the boys had worked hard for several hours throwing and hog-tying a lot of them to prepare them for the "ceremony." Several horses had been decorated with dry raw hides tied hard and fast to their tails, while huge cowbells had been strapped about the necks of fifteen or twenty more. The herders sprang to their feet and met the oncoming horses with shots from their rifles. This served rather to make the work of the animals even more destructive, for they tore back and forth across the park into and out of the bands, leaving a 
wake of dead and maimed sheep and throwing the whole 25,000 into one almost inextricable mass of bleating, terrified animals.

As soon as the horses were well launched into the sheep the rascals who engineered the jols swung around the place to a safe distance, while the horses finally drifted on into the darkness, leaving some dead; but this was a small loss in those days of cheap range horses. It took the sheep-herders a full week to untangle the mess and separate the various brands and marks into their respective bands. Nor were the sheepmen backward about obtaining revenge so far as lay in their power. While some of these predatory losses were great, still in the end they obtained the grass for their sheep, and had the satisfaction of knowing that their enemies suffered by the devastated ranges far more than did they from the loss of a few sheep.

Happily, however, the days of such deeds have passed. Today looking back over it one wonders what we were all thinking of and how it was that more lives were not lost than were. Only those who have passed through these times can fully appreciate the reasons and causes which led up to such apparently lawless acts. There was no legal justification for any of them, and they were certainly discreditable to all concerned. In spite of all such attempts to curb its progress, the sheep industry has gone on almost without a pause, until today it is too firmly intrenched in the West to be disturbed or forced back by any other class of domestic stock.

Government Control of Grazing Lands.-CThen came the demand for some sort of Govermment control of the ranges. It came from the cattlemen at first, and for several years the sheepmen have refused to admit its value 
or necessity. The results of regulated grazing upon the various National Forests have however been a good example of what could be accomplished by some reasonable range control. Conflicts have been avoided; depleted ranges have been restored, and it is the boast of the Forest Service that not a single hostile shot has been fired between the two interests, nor any stock maliciously killed on the National Forests, since they were established.

Today many of the leading sheepmen of the country believe that the permanence of their business will be guaranteed by a general supervision of the grazing ranges by some authority whose presence will prevent overstocking, too early grazing and complete destruction of the range, together with guaranteeing its fair division between all users. The only question in the matter is one of enforcement. On this point the sheepmen differ. An obstructive majority demands to be let alone, although admitting many of the claims made by the more progressive. They are fearing they know not what in the administration of the law. They realize that the case is urgent, and that the patient needs attention. They concede the necessity for calling a doctor, but cannot agree as to which doctor they should have.

A law covering this question, drawn by men of both sides and believed to be as fair and just as such a law can be made, has been introduced in Congress. A copy of this bill is printed in this work to show exactly the points involved. Its passage depends wholly upon the amount of support it receives from the stockmen themselves. At present the cattlemen are almost a unit for it, while a majority of the sheep interests are opposed to it. That it will some day become a law seems certain. 
The Curtailment of the Open Range.-Within the last eight years the inroads made by irrigation systems and dry farmers have been serious, from the point of view of the stockman using the range. Vast areas hitherto supposed to be fit only for grazing have been torn ip by the farmer's plow, and while nut all of it has been farmed, there is so much fencing on the ranges that portions of the rest cannot be utilized successfully. This is especially true in the Dakotas, New Mexico, western and northwestern Texas and Colorado, where thousands of cattle and sheep have been crowled from their ranges and forced onto the market, owing to the advances of "the man with the hoe."

Still there are millions of acres that under no conditions now known to civilized man can possibly be used for any other purpose than for grazing stock. Hence its preservation from destruction, that it may continue to furnish its portion of feed for the western stockmen's herds, is a most vital problem for this country.

The New Era.-The day of the "all-year-round" open range business has almost gone. In its place must come a proper utilization of the natural forage, supplemented by the crop of the farmer when, through drouth in summer or pitiless storms in winter, the natural grasses and forage cannot be obtained. There may possibly be fewer but better cattle and sheep under these conditions. There will be more wool to the sheep and a higher grade, more weight to each steer and less waste in long horns and legs, fewer cheap horses and more worth $\$ 150$, and more stockmen-farmers with great haystacks in the feedyards as an insurance against winter losses.

This briefly is the history of the open range stock business in the western United States. First came the 
boom days, between 1877 and 1886, and then a period of reaction up to 1890 , when the wool-growers began to gain a footing on the range. This was followed by a readjustment of the business to common-sense methods which, while bettering the industry in many ways, still lacks somewhat in permanence and stability. The final touch of some proper Government control or supervision of the ranges would tend to place the industry upon a first-class business footing.

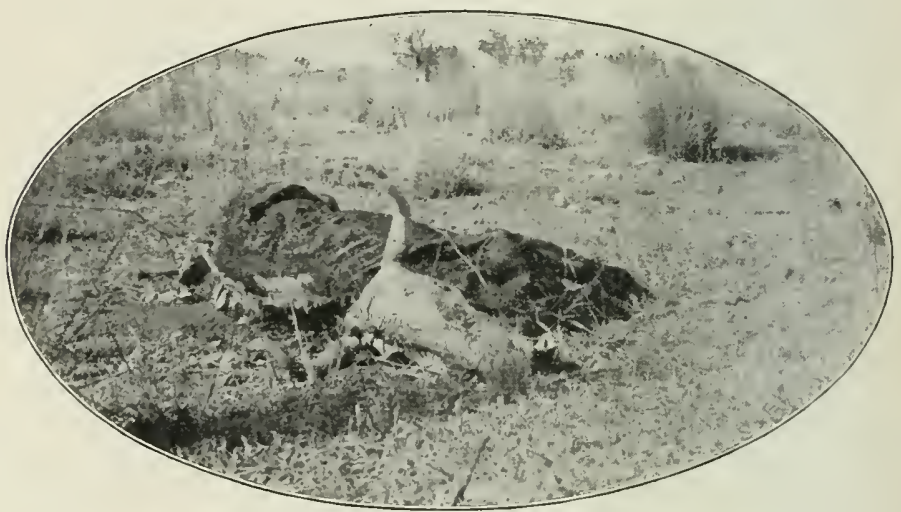

The Certain Result of Overgrazing. 


\section{PROGRESS OF THE RANGE BUSINESS.}

In the phraseology of the western stock-raiser, there are two distinct ranges-the southern or breeding range, and the northern or finishing range, sometimes called the steer range. Broadly speaking, the states of Texas, Oklahoma, Arizona and New Mexico and the southern half of Coloraclo constitute the sonthern or breeding range. The rest of the Rocky Mountain states form the northern or finishing range.

After the great die-off in 1886 the stockmen of the northern range practically abandoned the raising of calves and turned their attention almost wholly to the handling of steers. The long cold winters were not well suited to the raising of calves under open range conditions, but the quality of the grasses found on those ranges gave a growth and finish to the young spindlelegged steers brought up from the southern breeding ground that made them almost equal to the corn-fed article.

The Southern Steer Trade.-Thus there grew up a regular trade between the two sections, and young steers by the thousands were moved northward every spring from the southern ranges. The animals began their long journey in the cars, but owing to the lack of railroad facilities the majority of them left the road and finished the trip on foot. 
Cheyenne, Wyo., was for several years a great point for the unloading of southern steers northward-bound, and later on Orin Junction, through the extension of the tracks, became the center of this business. Here the steers, thin in flesh and sore from their rough usage in the cars, were unloaded. After being decorated with their new owner's brand-some were branded in the Denver yards as they passed that point-they were started out on the trail for their destination. As the shipments were generally timed to bring them there with the early spring grass, they grazed their way, picking up in flesh from the day they started, so that by the time they reached their owners' ranges they were "on the mend" and gaining weight rapidly.

Steers thus brought up were generally kept on the range for one winter and two summers, being marketed the second fall. Many of them, however, were "doublewintered" and not shipped until the third summer. If the season had been a good one this class of steers was eagerly snapped up by the exporters for foreign trade, being considered without any further finishing equal in every way to corn-fed cattle. Many of the "single-wintered" steers were also taken for this trade, but the larger part of them went to the feedlots of the cornbelt states like Illinois, Iowa, Indiana and Ohio. Here with a short season of corn they come back onto the market a truly finished product.

Southern Steers in the North.-At the beginning of the business the shipments were about equally divided between yearlings and two-year-olds. A few winters' experience, however, satisfied the steermen that yearlings were not able to stand the first winter so well as twoyear-olds, and eventually the majority of the shipments 
were confined to twos and threes. The manner in which these young suthern steers "spread out" under the influence of the luxuriant worthern grasses was surprising. Steers that under ordinary conditions in the south would never have weighed more than 900 pounds reached Chicago tipping the beam at 1,250 pounds. The writer has seen shipments of his own steers-miserable little runty affairs sent up from Arizona, unloaded in the Chicago yards. Ifter two winters in Montana, they had become great full-ribbed brual-backed fellows which but for the brand and ear-mark lie never could late believed were the same animals. They were sold in Arizona for $\$ 12.50$ each and brought in Chicago more than \$75 per head, netting the enmpany owning them about $\$$ to each.

Once they reached the ranges there was rery little loss on these two-year-obls from either weather conditions or other causes. The most severe losses were incurred during the shipment from the southern ranges. In order to reach the northern ranges early enough the steers were started on their journey in April and May when they were thin and weak. If cold storms were encountered on the roal the cattle were easily chilled, and dien like flics. In 1so4 one shipment which I recall lost 25 per cent of the bunch one night in the Cheyenne yards, owing to a cold sleety rain which chilled them to the bone. llundreds died even with plenty of hay before them

Curtailment of Northern Movement.-Since 1906 this trade in southern steers has fallen off to a very great extent, due to several causes, the principal one being the curtailment of the open ranges in the North through various reasons-settlers and the inroads of the sheepmen - until the anmual shipments do not amount to one-fifth of what they once were. 
Neantime the northern cattleman has learned that with a full feedyard at his elbow he too can raise calves. The larger herds are gone, but there are thousands of small owners who have gone back to breeding stock and are engaged in raising a superior grade of cattle for their ranges.

The southern breeders now have found another outlet for their steers in the corn-producing states. There land in some sections is thought to be too high-priced to raise cattle on, and the farmers find it cheaper to go west and buy steers as yearlings or in many instances as calves, and force them to a quick finish on the very best of beef-producing materials.

A Southern Lamb Trade.-The sheep interests in the Southwestern ranges have opened up a trade in lambs which on the whole has been very profitable. The lambs raised there, especially in New Mexico, were found to be well suited for winter feeding. The lamb feeders around Fort Collins, Colo., and other points, where in recent years this branch of the business has grown to the dignity of a great industry, were quick to realize their value. Probably three-quarters of a million lambs are shipped each fall from New Mexico ranges into the western lamb-feeding districts and even to the far eastern feedlots. Their good health, fine feeding qualities and handy weight when fed makes them well fitted for market feeding purposes.

The feeding is principally on alfalfa hay, with additional rations of corn, kafir and similar grains. On a well balanced ration of Kansas corn and plenty of alfalfa the gains in weight made by these hardy little fellows is remarkable. They come into the markets along in February, March and April, just at a time when there is 


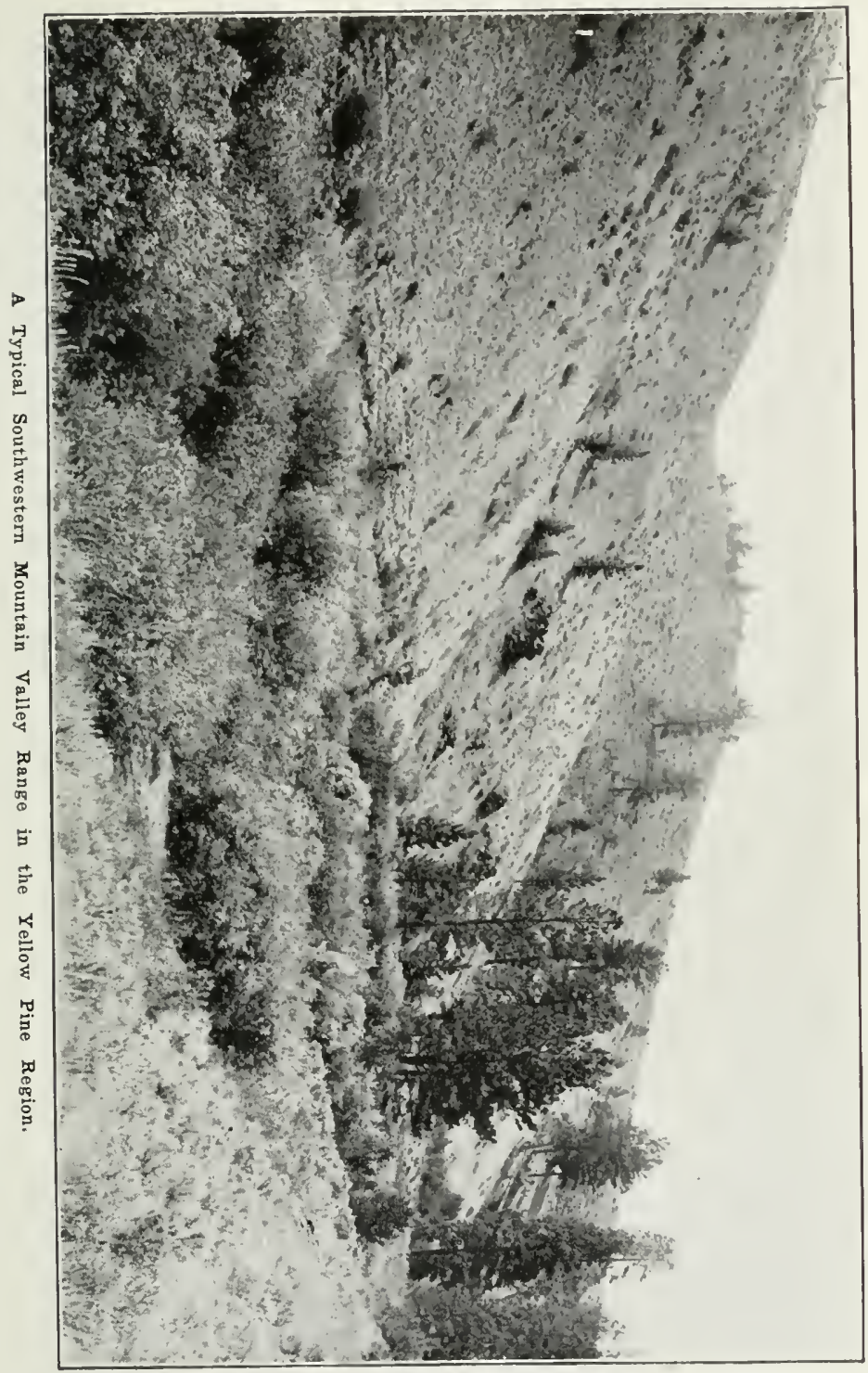


little competition from other sources and generally bring the top prices. Some have made fortunes for their owners.

Grasses and Forage of the Southern Range.-There are two distinct types of range in both these great divisions of the West. While the greater part of the southern range is what is known as desert range, there is also an area of country classed as mountain range. This latter forms probably one-fifth of the total available range.

On the desert ranges, which lie at lower altitudes. we have a great variety of stock forage with comparatively little grass. A typical desert range is the great stretch of country in southern Arizona lying in the foothills of the Salt and Gila Valleys. This range is generally all below an elevation of 3,000 feet and lies in the region of long hot summers and cool pleasant winters. To the uninitiated there seems to be but little feed for stock but, given the usual summer rains, which should begin in early July, the stockman knows his herds will not suffer for feed. With the summer rains come a rapid growth of weeds, brush and other forage plants upon which the stock thrive.

Mesquite beans (Prosopis) furnish feed of a high nutritive value, and it is a strange sight to see the catthe and horses eating the long yellow pods, often getting down on their knees to reach the beans lying all over the ground under the low-hanging boughs of the trees. Under ordinary climatic conditions there are two crops a year of mesquite beans, the pods of which are rich in nitrogen. The Indians in this region grind the beans into flour from which they make bread.

Then there are many families of sage, which all stock 
appear to relish, while the leaves and tencler branches of the mesquite and catclaw (Acacia (ireggii) and the blossoms and fruit of the Spanish bayonet (Yucea) furnish no small part of the available forage.

The AIfleria Plant.-If the season is a gorol one liere the winter rains will set in along in November and December, and by the first of February the alfileria (Erodium cicutariums) will begin to make its appearance upon the deserts where previonsly there seemed to be nothing living. From a surface as bare of regetation as a floor, this splendid forage plant will spring up almost in a night. Sheep and cattle fatten on it as if fed alfalfa liay. Alfileria was doubtless introduced into this southern region through the migrating sheep from California, where it las been known for many years. The seeds hanging to the wool of the sheep were scattered orer the ranges and, finding a climate and soil peculiarly well fitted for its reception and growth, it spread rapidly. and now covers a great area of the desert ranges. Alfileria also is known as "heron's bill" and "pin clover."

The plant belongs to the geranium family, has a little pink star-like blossom, and is a native of the hot, dry region about the Mediterrancan. The name "Erodium" is derived from the Greek word "erodius," a "heron," from a fancied resemblance of the fruit to a heron's hearl and bill. With plenty of moisture it grows very rapidly, and in six weeks' time the barren desert will be covered with a carpet of rich green. Having reached an average height of from 6 to 10 inches it begins to cure, and in six weeks more it is gone.

The change from bare earth to green and back to bare earth is remarkable. As soon as it ripens and dries, the winds break it off at the ground and it blows into 
great piles much like tumble weeds in the open plains further north. Arroyos and washes will be filled full to the top; it banks up against trees and thickets of greasewood in huge windrows and in a short time disappears with an almost magical suddenness.

Alfileria thrives best on a decomposed granite soil, and while it will grow above 3.500 feet it does not grow tall enough above that altitude to be grazed by stock, clinging very closely to the ground and forming a dense green cover which furnishes but little feed. Contrary to general belief the cold weather does not kill it out, as the writer has seen it near Las Vegas, N. M., over 7,000 feet above sea level growing year after year where the winter temperature frequently falls to $10^{\circ}$ or $15^{\circ}$ below zero. It has also been carried by sheep intu northern statesIdaho, Utah and Montana-but as a rule does nothing more than spread orer the ground in a thick close-clinging mat of green.

Besides this there are many weeds peculiar to the region, all of which stock like, and a few are almost equal to alfileria for sheep feed. Py the middle of April the feed begins to dry up on the desert, and the stock is moved back into the foothills and mountains.

Hundreds of thousands of sheep are grazed every winter on this desert feed, and every spring the shipping of lambs from this region to the eastern market reaches a quarter of a million head.

The Semi-Desert Range of the South.-There is still another type of desert country in this region of which the San Simon Valley in southeastern Arizona is a fine sample. Beginning in the neighborhood of IVilcox, Ariz., this range stretches cast into New Mexico to a point about lialfway between Deming, N. M., and El Paso, 


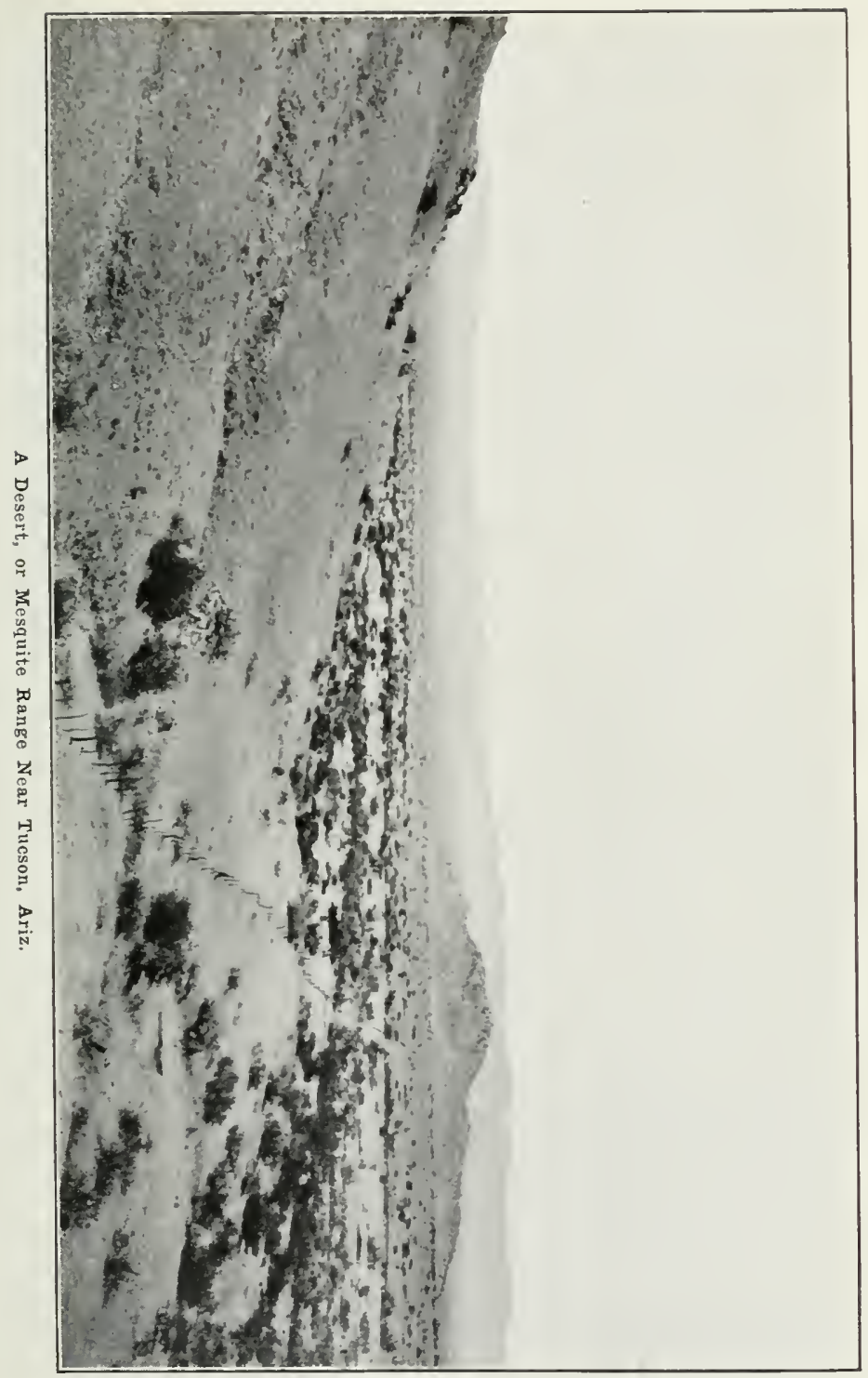




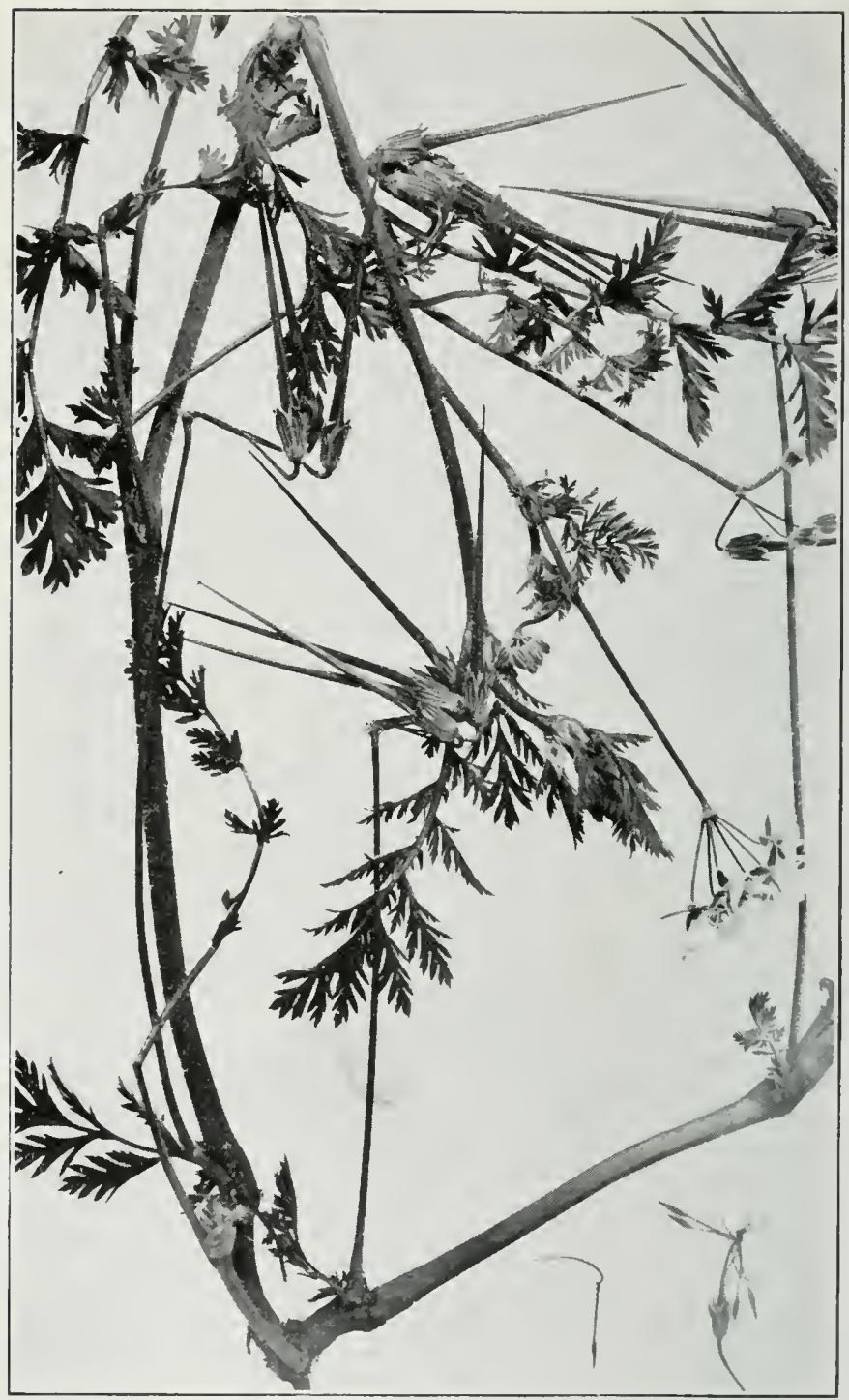

Alfileria (Erodium cicutarium), "Filaree," 
Tex. It generally lies between 3,500 and 5,000 feet elevation, and is characterized by open prairie, broken here and there by rough mountans. While there is comparatively little surface water here, well water can be obtained in plenty at moderate depths, and wiudmills furnish watering facilities sufficient for all the stock.

This area may properly be classed as a semi-rlesert country with comsiderable grass, mostly the gramas (bouteloua) and species of Hilaria known varionsly as Galleta (guy-et-ta), black bunch grass and curly mesquite. There is also sacaton (Sporobolus airoides), sometimes but erroneously called salt grass, and many varieties of sage (Artemesia.) There is an immense growth of yuca (Spanish bayonet), of which both the flower and the long banana-like fruit are greedily eaten by cattle. In the foothills there are several varieties of edlible bushes like Mountain mahugany (Cercocarpus) and the catclaw and mesquite fomm elsewhere.

Owing to the presence in many portions of both these desert regions of a grass known as needle or dogtown grass (Aristida) and porcupine grass (Stipa spp.), the sharp awns of each of which work into the wool and finally into the very skin of the animals, sheep cannot be successfully grazed in these lower desert ranges, excepting in the immediate valley of the Salt and Gila (He-la) Rivers and north of them. In southern Arizona I have seen the meat from sheep killed by local butchers, so badly inflamed and festered by the sharp awns of these grasses as to be unfit for use.

Higher Ranges of the Southwest.-In the foothills and mountain ranges of the Southwest is found a great variety of grasses and forage plants. These ranges generally lie about the 5,000-foot line and, as elsewhere all 


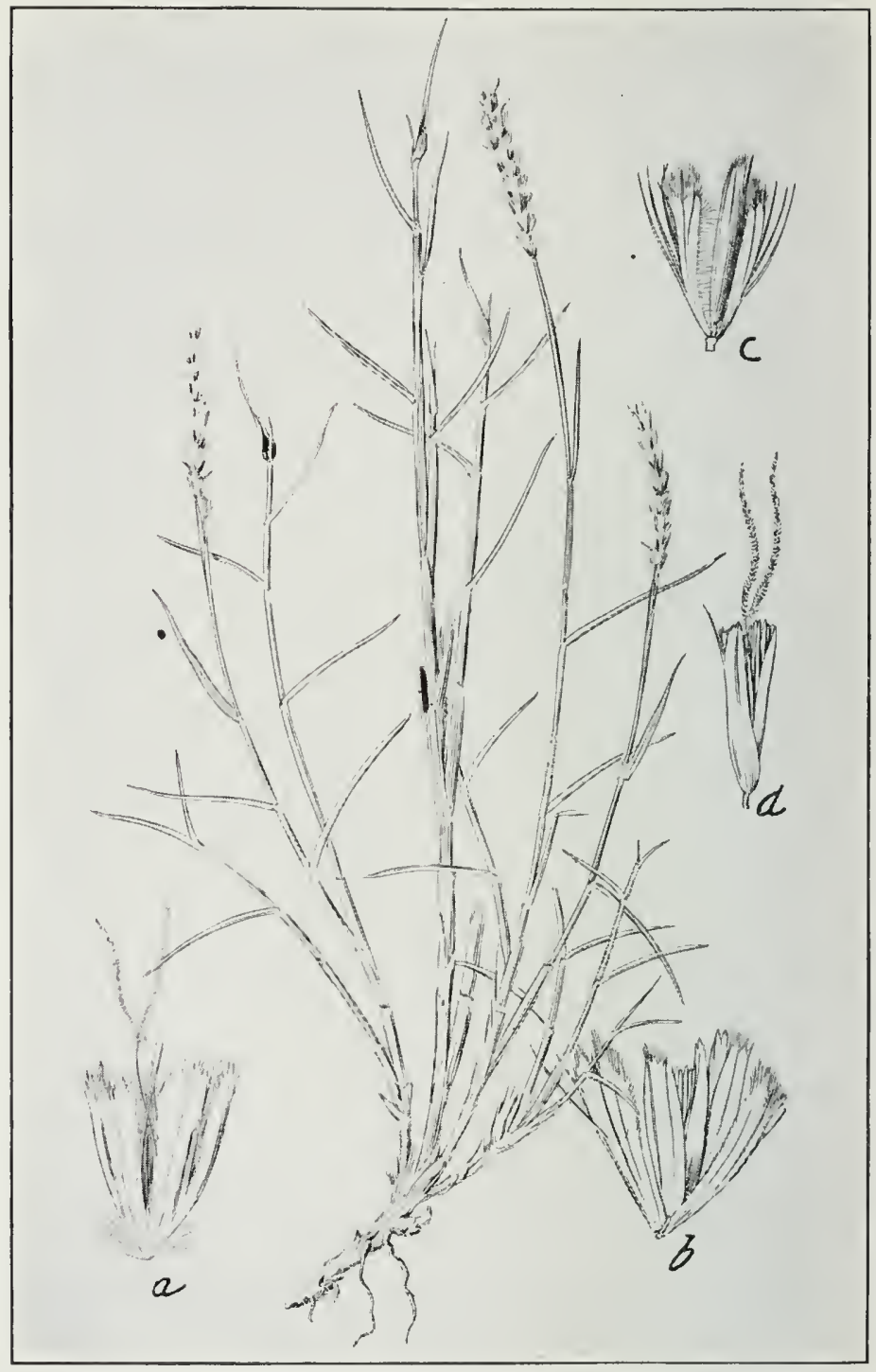

Galleta (Hilaria rigida), Pronounced Guy-et-ta. 


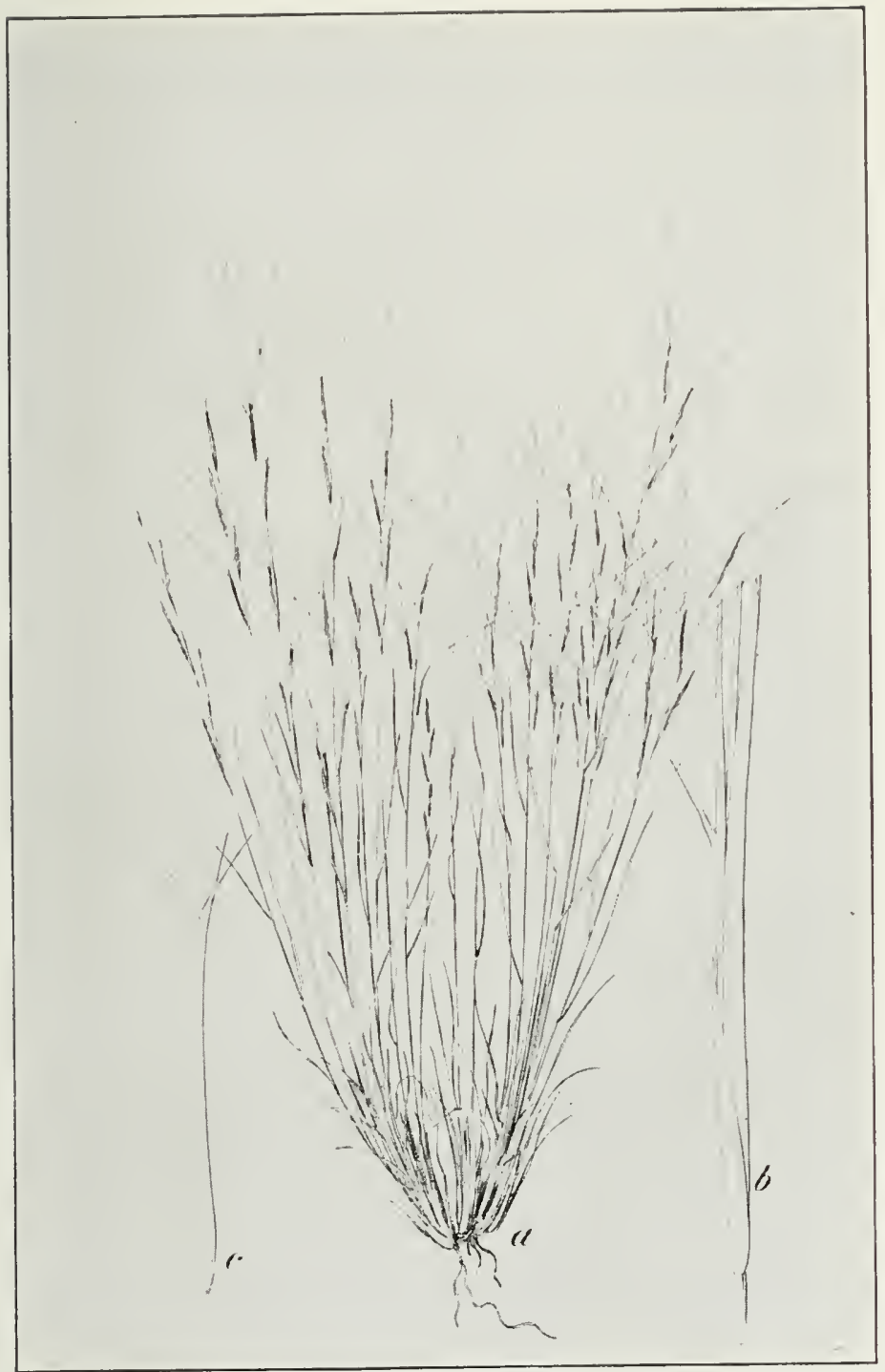

Needle or Dogtown Grass (Aristida longiseta). 


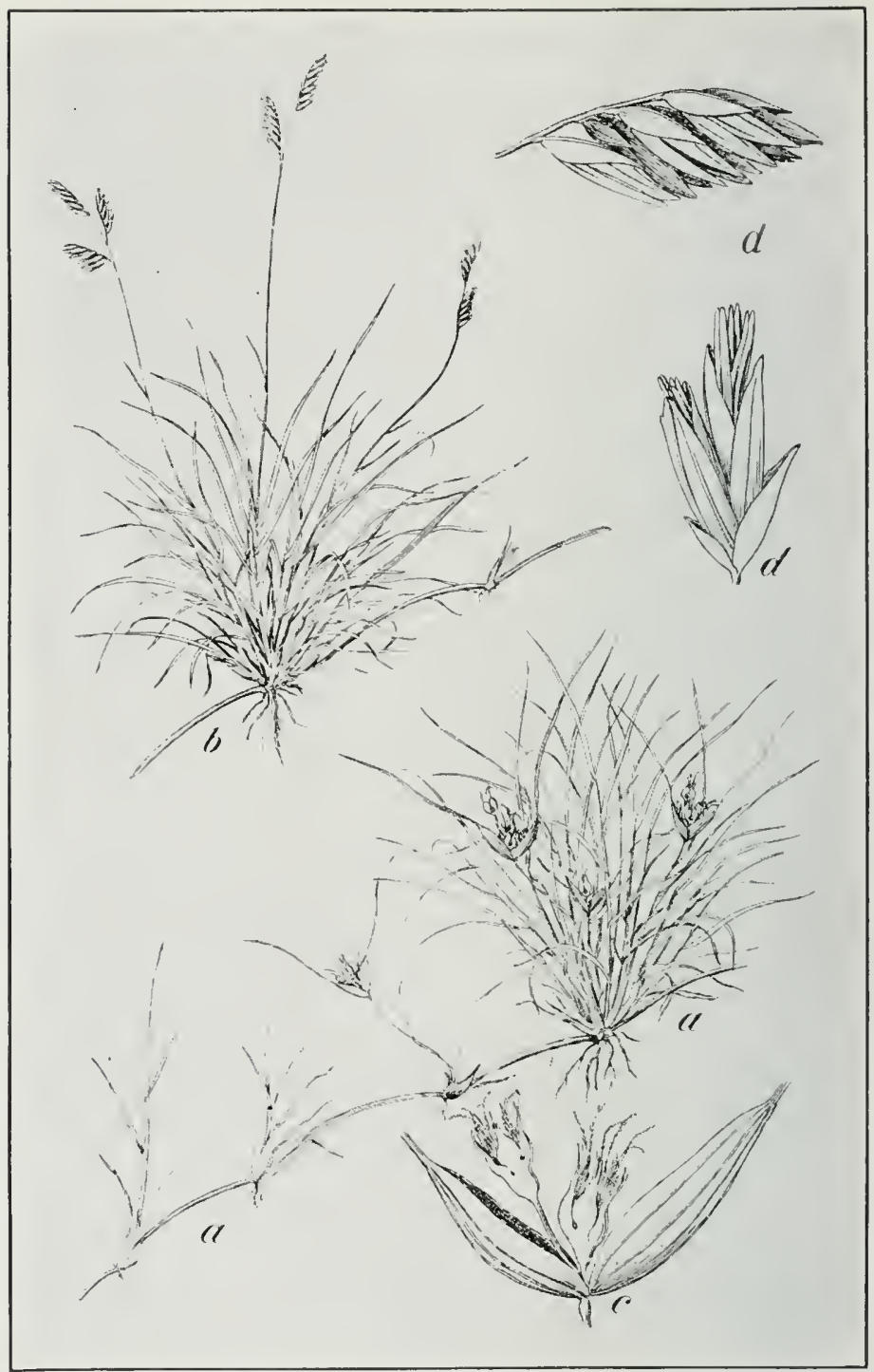

Buffalo Grass (Bulbilis dactyloides). 


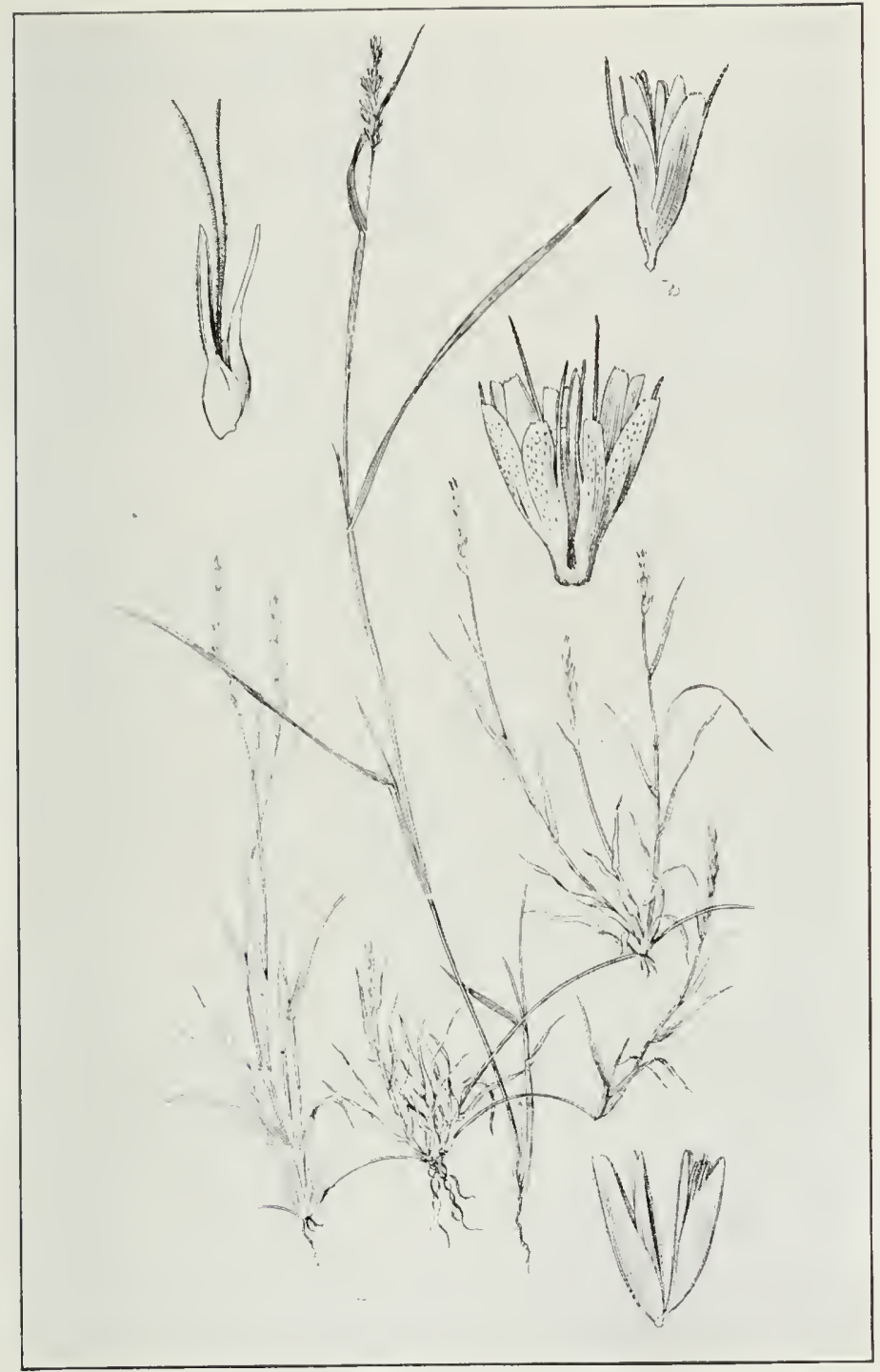

Curly or Creeping Mesquite (Hilaria cenchroides), 


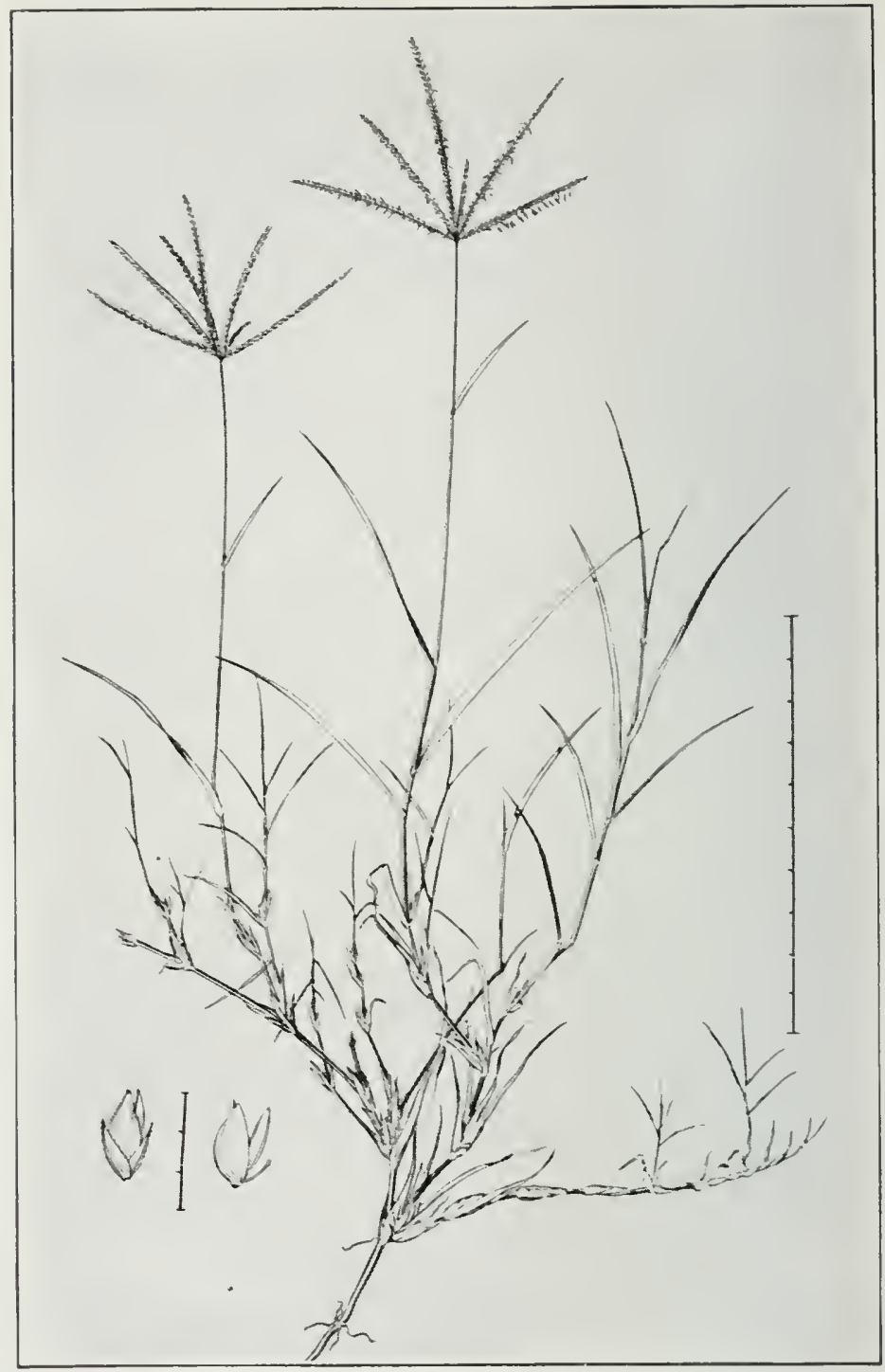

Bermuda Grass (Capriola dactylon). 
over the West, the grama is the 1110st valuable and stable of all the grasses. On the great grassy plains of Texas and eastern New Mexico, the staked plains (El lano Estacado-Yah-no Es-ta-cab-do) of the olden days, the grama is the prevailing grass.

The staked plains were so called because of the story that one of the early Spanish exphoring expeditions in western Texas, in order to mark their trail, placed stakes at intervals along certain parts of their route, which remained for many years as a guide to travelers. The nure likely but less romantic reason is that rast stretches of the plains bear great quantities of the Spanish bayonet (yucca) whose tall pole-like stalks dry out and look like a forest of fish poles. Seen at a distance these yucca stalks are not unlike stakes, hence the probalsility of the origin of the name from this cause.

Southwestern Grasses.-I l lere too is found the buffalo grass (Bulbilis dactyloides) and the curly mesquite (Hilaria cenchroides), both somewhat similar in appearance and characteristics of growth. Tuffalo grass may easily be known from the ordinary gramas, for, while having the same peculiar spikes or seed heads, it is alone in its peculiar creeping habits with little rootlets springing from each joint much as does the Bermuda grass (Capriola (lactylon).

There is an immense amount of misinformation all orer the WVest among stockmen regarding the names of these common grasses, so that a study of the plates showing them should repay many readers.

Black Grama Grass.-Take black grama, for instance. Most stockmen apply this name to the ordinary grana which is most prevalent but which is really blue grama (Bouteloua oligostachya) or galleta (gai-et-ta) (hilaria). 
Neither of these is the true black grama. liack gramat (Muhlenbergia porteri) is found on a rather small area of the Southwest, being confined principally to the ranges in the Gila River basin in southern New Mexico and Arizona. It is quite unlike any of the other gramas and once seen need never be mistaken for one of them. It grows from a single root and flourishes best beneath trees and shrubs which protect it from destruction, and in such an environment it sometimes reaches a height of three feet, climbing up through the sage brush like a vine. The stems and leaves are quite dark, almost black; the seed heads are entirely different from the other gramas and the grass is a rather soft delicate plant.

It was originally a common plant in the region mentioned, and was one of the main sources of hay for the Government military posts in southern Arizona. At Camp Thomas on the Gila and Forts Bowie and Grant in southern Arizona in 1879 and $1880 \mathrm{I}$ saw hundreds of tons of this grass delivered to the various post quartermasters as hay at prices varying from $\$ 2.5$ to $\$ 50$ and sometimes more a ton. A large amount of this was hoe-cut hay and advertisements calling for bids for Gorernment contracts frequently specified hoe-cut hay.

This was because hay cut that way was cleaner and of better growth than when cut by scythes or sickles, for machines were practically unknown in that region at that time. To procure hoe-cut hay a wagon was driven across the range and the Mexicans, each armed with the common heavy Mexican or planter's hoe, worked on each side of it. They simply chopped off the plant at the roots, not infrequently getting deep into the ground, for that made the hay weigh more. The hay was thrown onto the wagon and five or six men could accumulate a 


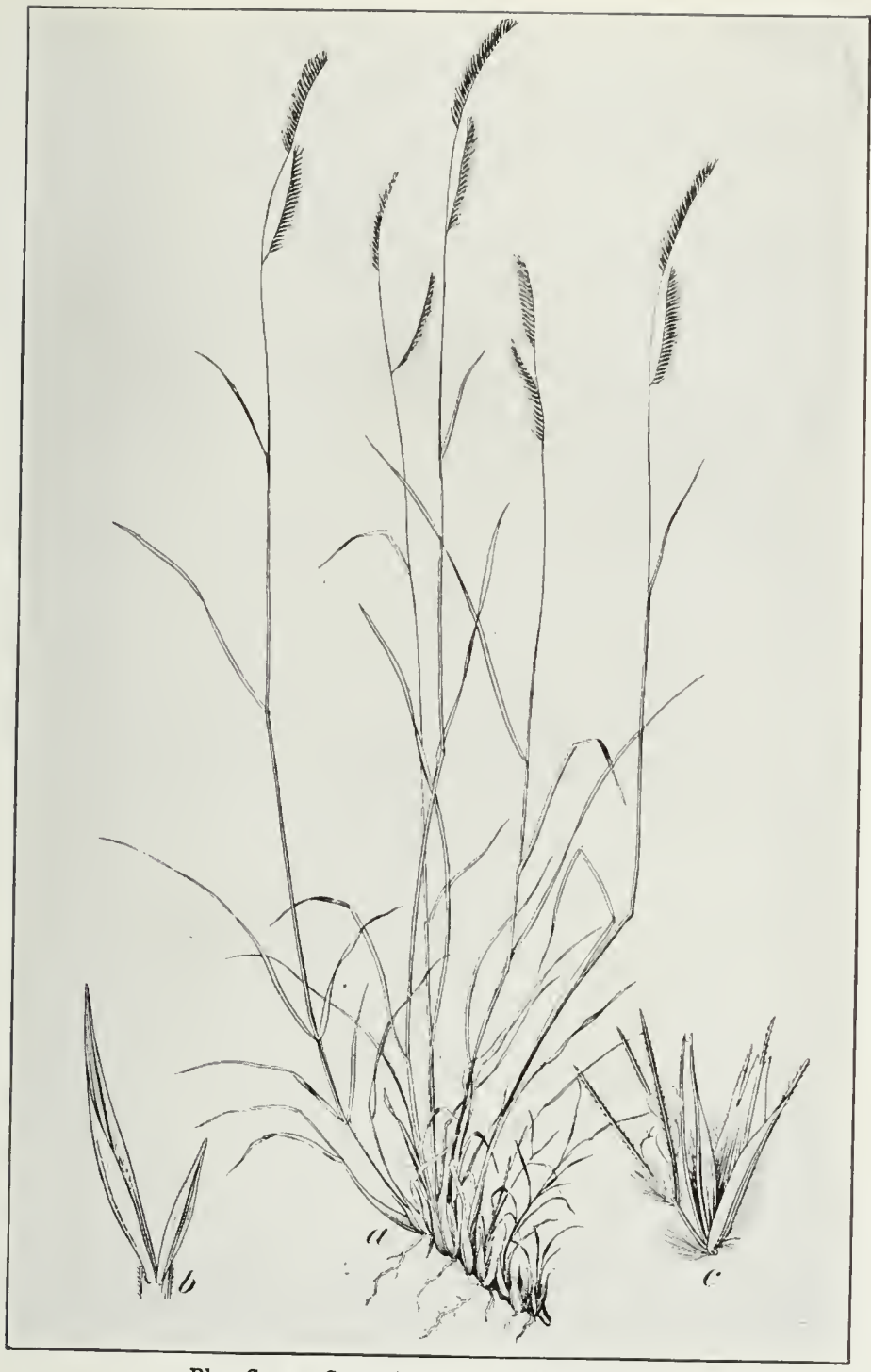

Blue Grama Grass (Bonteloua oligostachya). 


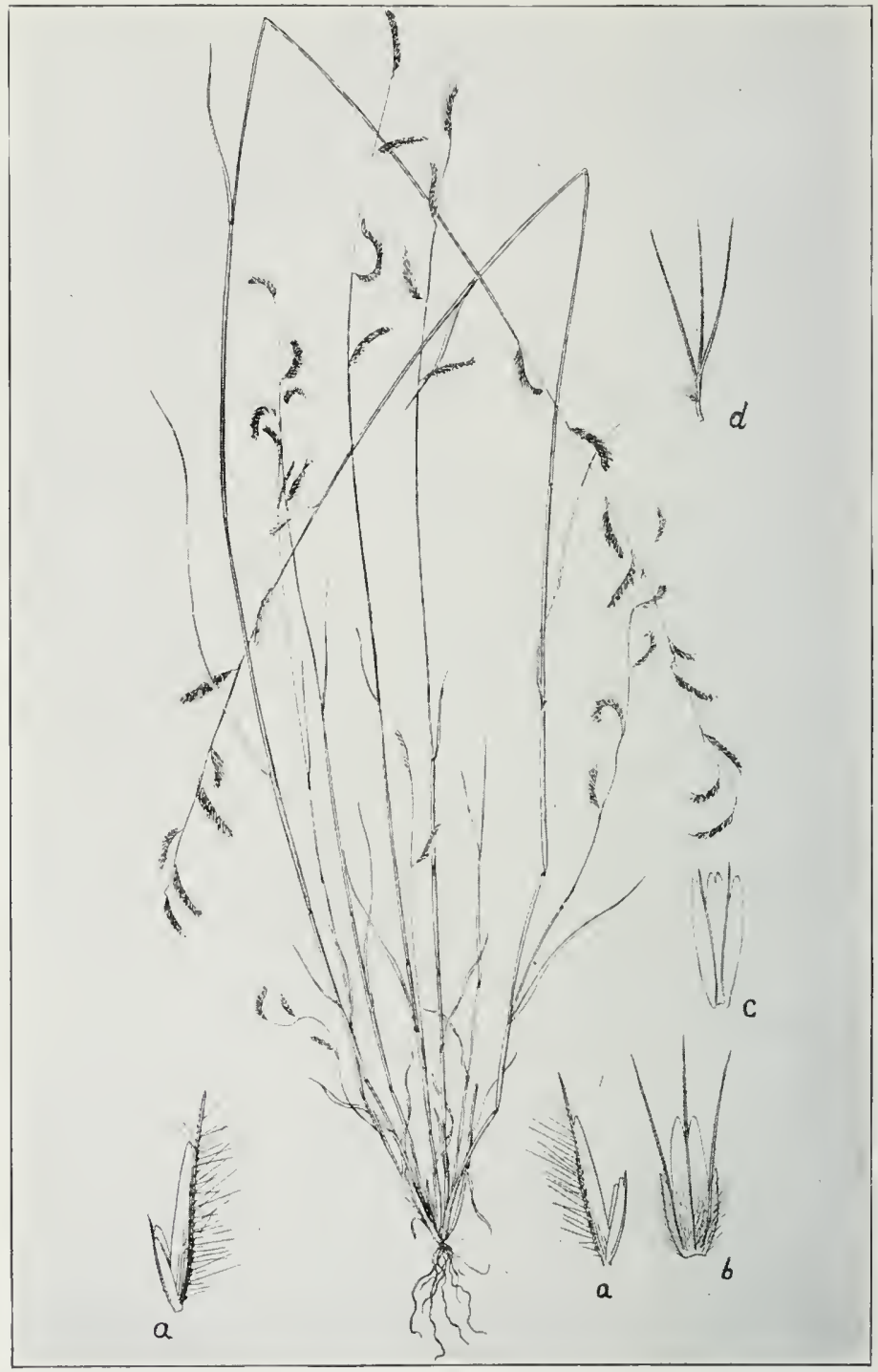

Hairy Grama Grass (Bouteloua vestita). 


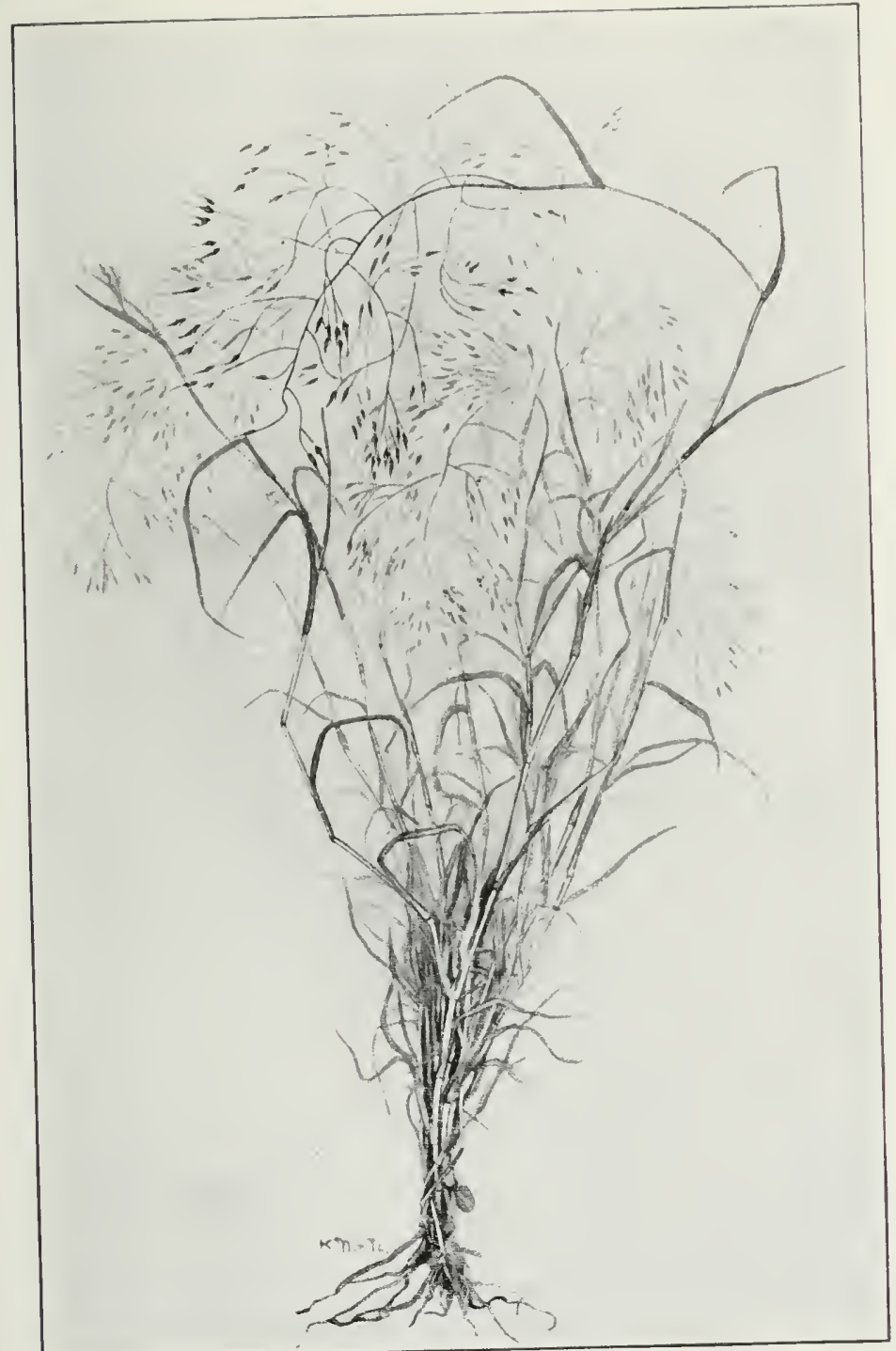

Black Grama Grass (Muhlenbergia Porteri).-[From a photo loaned by Prof, J, J, Thornber, Tucson, Ariz.] 
load in a very short time by this primitive and wasteful method.

Where wagons could not work, burros and horses were used, and the grass was packed on their backs. Not infrequently the Mexicans and Indians brought the hay in on their own backs tied up into great bundles with soap weed strings (yucca.) I saw a Mexican or an Apache Indian woman pack 150 pounds of this hay at the scales, with her baby's basket on top of the load. The hay was swung from her forehead by a flat strap fastened to the soap weed strings. Under such methods of harvesting it is not singular that the black grama is an almost extinct species at the present time, and I fancy that it would take many days to find a ton of it now where they formerly gathered it by the hundred tons.

Sacaton.-There are great areas along the rivers and in the alkali lands which grow a fine crop of sacaton (Sporobolus), sometimes, but erroneously called salt grass. Sacaton (sac-ah-tone) starts very early in the spring and while young is relished by all classes of stock. It grows rapidly, however, and in six weeks becomes so rank as to lose its good qualities. Its greatest value is as an early grass for lambing or before other feed is up. and it also makes fine hay when cut at the right period of growth.

Sacaton will stand an immense amount of hard usage and it is almost impossible to injure it by either overgrazing or trampling. I have seen a herd rounded up on a sacaton flat for several days at a time, and milled and worked over the ground until it was trampled into a dust heap. As soon as the rains began, however, the green shoots came up from the hardy roots and in a few days there was apparently as good a stand as ever. The 


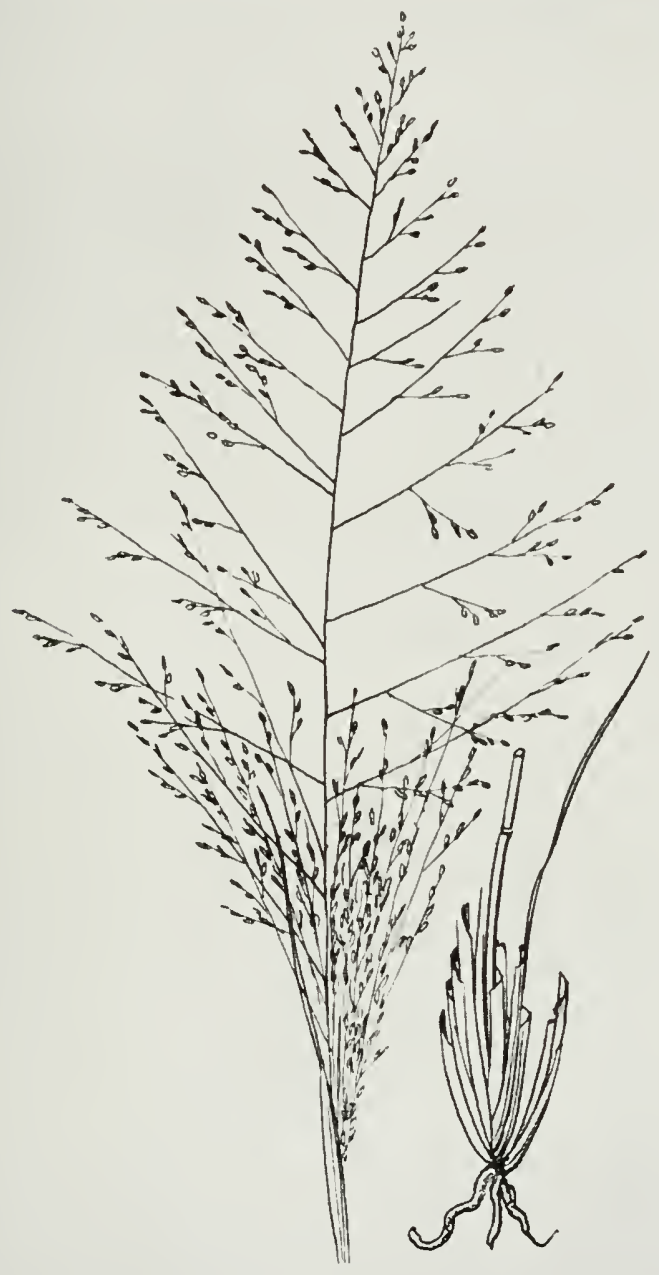

Sacaton (Sporobolus airoides), Sometimes Called Salt Grass. 


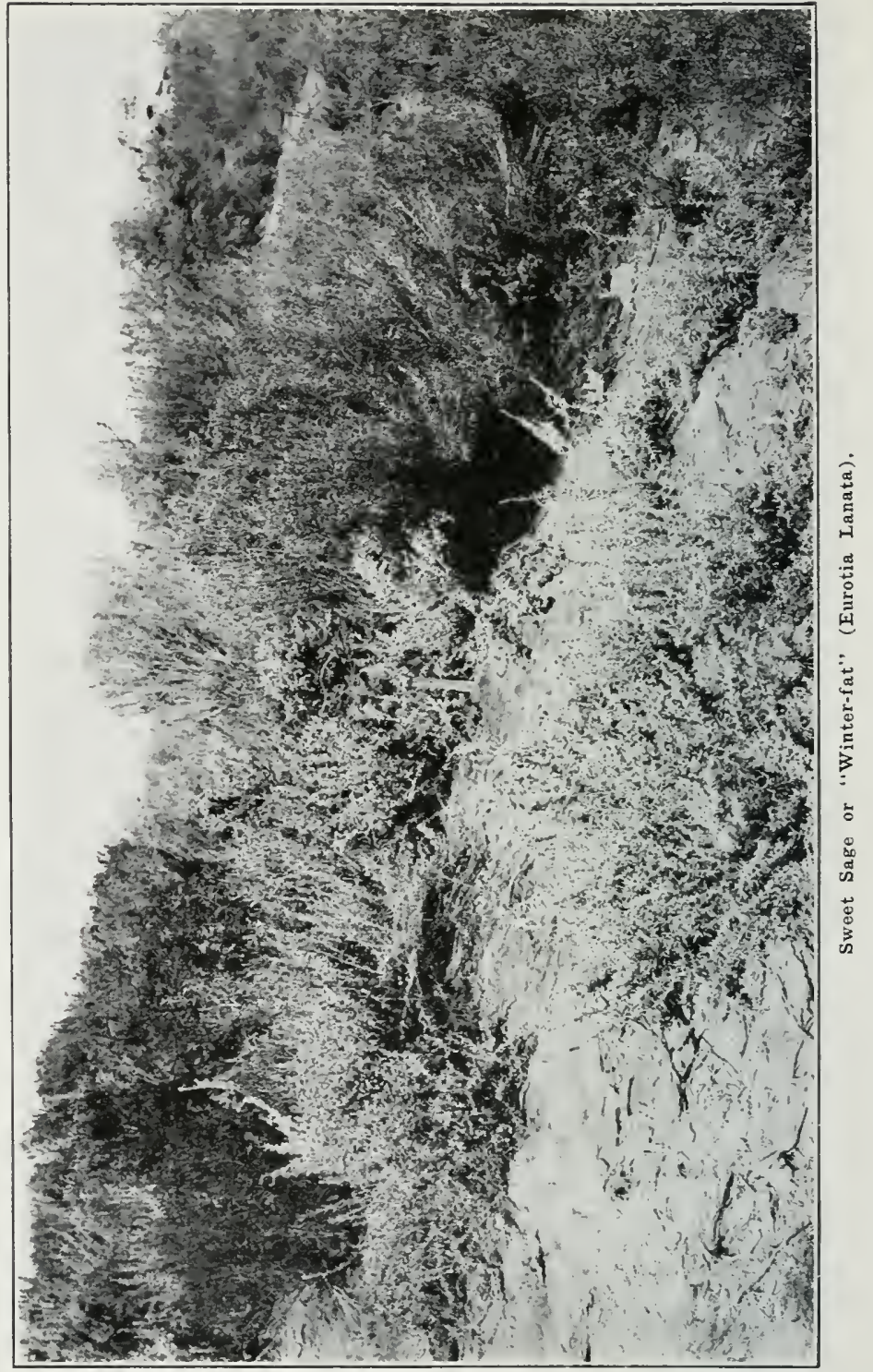


true salt grass of this region is Distichlis spicata, a light soft-feeling grass seldom more than 6 inches in height and of no great feeding value. It also is a very tough, hardy grass.

The Sages.--These two grasses, grama and sacaton, are the principal ones of the foothill region, but the forage is greatly atumented by the great sage family, especially the sweet sage or "winter fat" (Eurotia lanata), which furnishes an unequaled feed for stock, especially sheep and horses. There are many varieties of sage in the southern ranges, nearly every one of which is eaten by stock of every class. Salt sage (Atriplex) is the one most generally called by the generic name sage by stuckmen all over the West. There is another favorite forage bush known as shad scale( Atriplex canescens) called estafi-etta by the Mexican herders. To the ordinary observer it would seem to be absolutely worthless, but it is eagerly eaten by all stock, especially sheep. It furnishes a great supply of dry husk-like seeds which the sheep lick up from the gromnd, and even crawl on their knees under the bushes in order to get them.

Greasewood (Sarcobatus vermiculatus) is another favorite browse well liked by most range animals.

Prickly Pear (Opuntia).-In the foothills of this region prickly pear furnishes an article of diet for the catthe that in times of feed scarcity has saved many an old cow. In feeding it, the stockmen go out on the ranges armed with pitchforks and axes. By means of a lighted torch or a forkful of weeds, bear grass or yucca leaves, the sharp needles are singed off the broad leaves of the pears and then the plant is cut up with the axe and pitched to the cattle. Two men can thus feed a good many poor cows in a day and while it acts on the bowels 
with considerable effect the cattle thrive on it. It is astonishing how quickly range cattle catch onto what is being done, following the men with the torches and burning materials and waiting for it to be thrown to them. In southwestern Texas dairymen feed it regularly to their milk cows with good results.

Spineless varieties of the opuntia can be grown as any forage plant and furnishes a remarkable amount of feed. On irrigated land 25 tons per acre have been grown and harvested. Although advertised as a potent factor in securing some new range forage plant, the spineless cactus is not at all adapted to use on the open range. Its spineless character makes it an easy prey to rabbits and other rodents as well as grazing stock, hence if planted it must be carefully protected and looked after. Also any temperature below 20 degrees, if continued for several nights will kill it.

Feeding Mistletoe. - In the Southwest the mistletoe which is found so extensively clinging to trees on the ranges, especially the oaks and mesquites, has been utilized by the stockmen as a hard-times feed when other forage was scarce. The stockman armed with a long slender pole, to the end of which is attached an iron hook, reaches up into the trees, and by the aid of the hook the mistletoe branches are easily broken off, as they are very brittle. The cattle feed on it eagerly, following the men from tree to tree and watching for the branches to drop. An analysis of the plant shows that it possesses feeding value comparing favorably with timothy hay. Many cattlemen believe that if fed to cows about to calve or just having calved, it will cause them to "clean" more readily than otherwise.

In southern Arizona, New Mexico and western Texas 


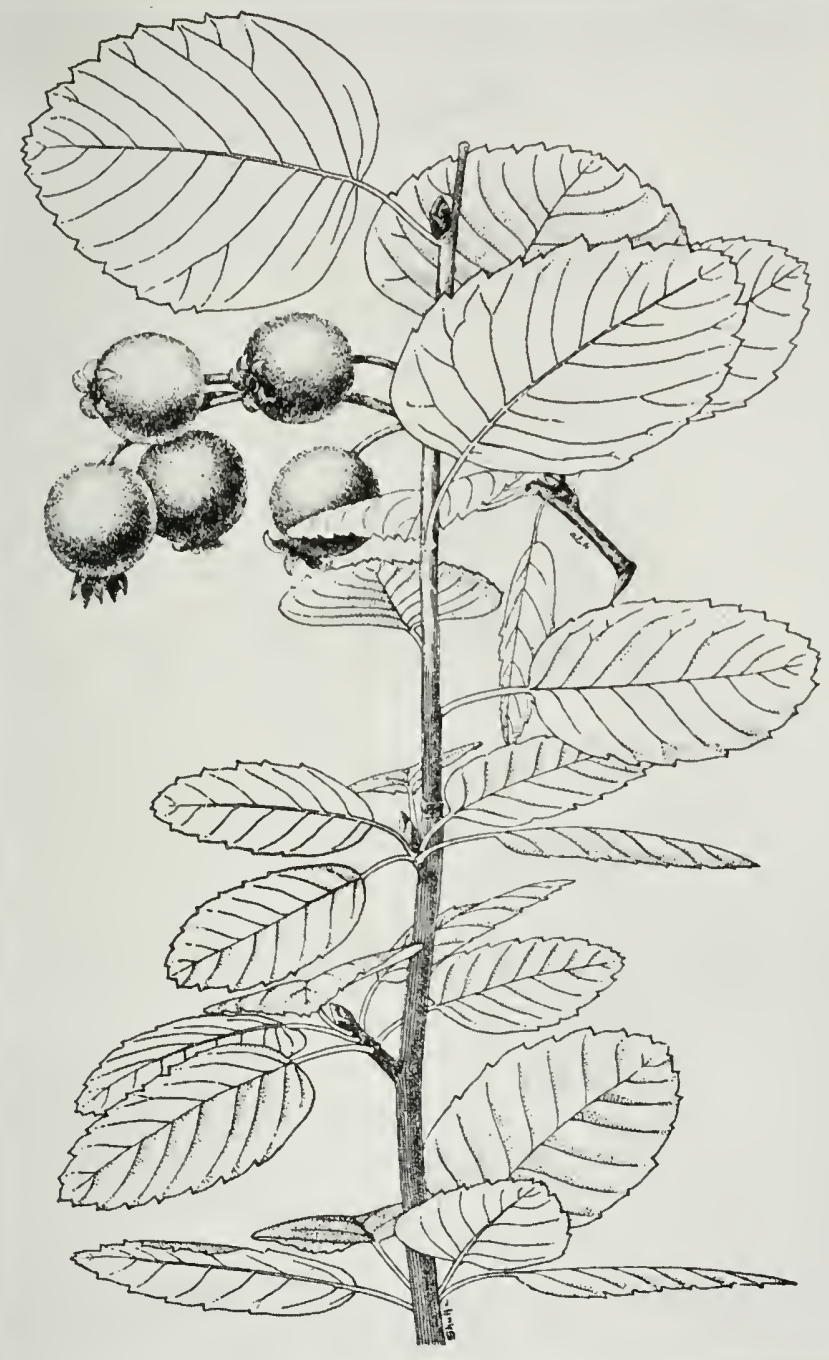

Service Berry (Amelianchier alnifolia), 


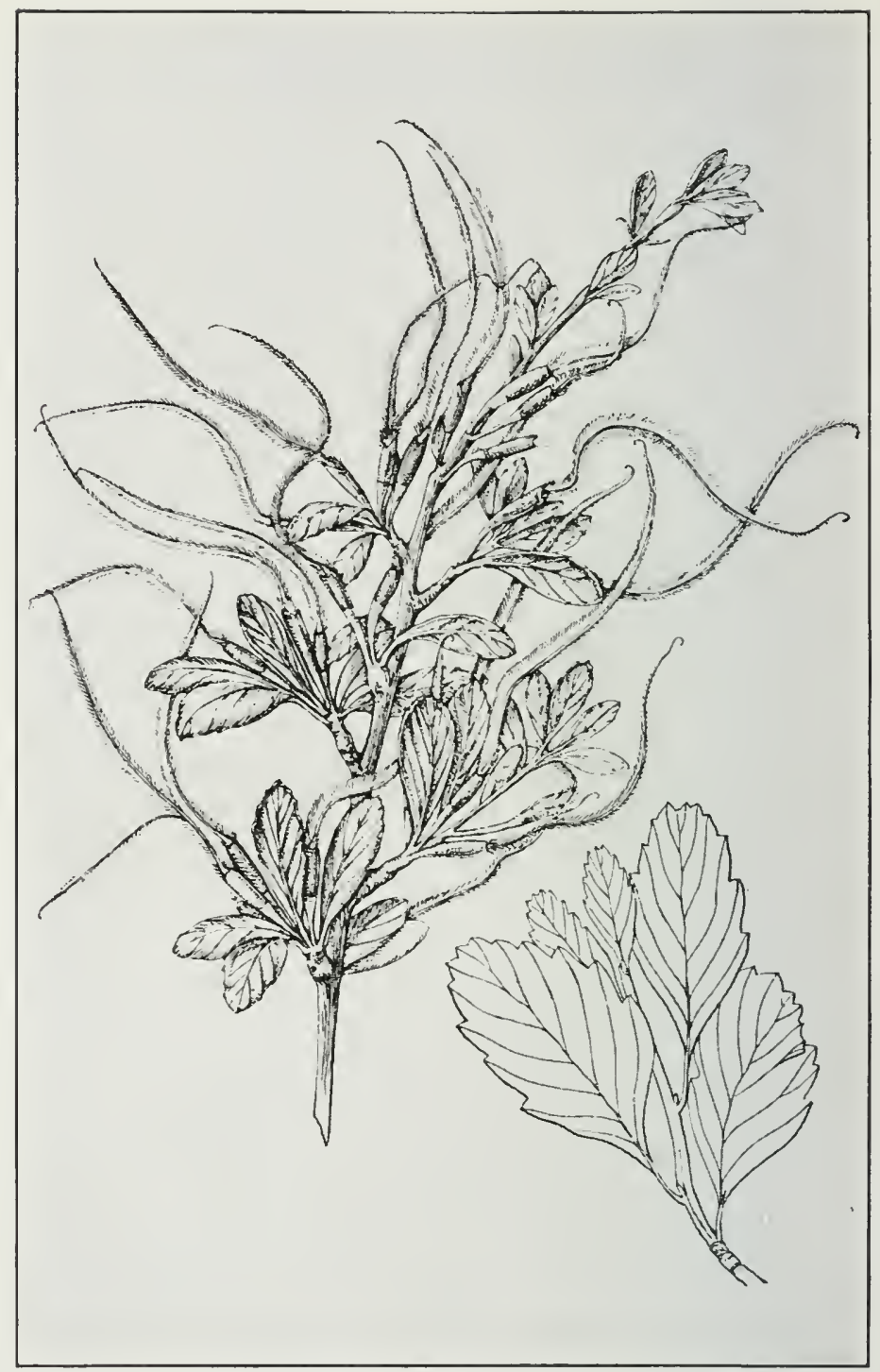

Mountain Mahogany (Cercocarpus parvifolius). 
mistletoe grows so profusely that it is an easy matter for one man to feed a great many cattle in one day on this plant. Incidentally he is removing a very harmful parasite from the trees.

Mountain Forage.-Going wy, into the nountains of this region, we find many varieties of grasses and plants. Here the gramas are still plentiful, while there is a festuca locally called pine or white bunch grass ( Festuca arizonica), wild vats (Avena fatua), timothy (Phlenm pratense), wild rye (Elymus canadensis), and the blue stem (Andropogon). liesides these grasses there are many varieties of weeds, lupines and other edlible forage plants, all of which are greedily eaten by sheep. In fact, in the higher mountain ranges everywhere the sheep eat far more of the class of plants commonly called weeds than they do of the grasses.

In addition to these grasses and weeds there are many varieties of browse in the higher mountains upon which stock feeds. In the foothills the tender shoots of the scrub oak (Quercus nudulata) (Q. gambelii) are eaten by cattle in the early spring, but if fed on too long they are very injurious, causing death in a short time from the tannic acid contained in the leaves.

The buck brush (Cowania mexicana), also called quinine bush, service berry (Amelanchier), mountain mahogany (Cercocarpus), and sages, all furnish a large amount of excellent forage for sheep, cattle, goats and horses. The Mexican sheep herders apply the word "chamiza" to a browse range.

The Northern Desert Ranges.-There is another type of desert range which lies at a ligher altitude than the two already described. The best example of this range is found in the famous Red Desert of southwestern $\mathrm{W}^{\top}$ yo- 
ming. The deserts of Nevada, Utah, some parts of California and in fact all of those states lying within the great intermountain region of the Rockies and east of the crest of the Sierras, have very much the same general characteristics, so that a brief description of the Red Desert will cover them all. There are, however, many varieties of forage plants and browses which are not found

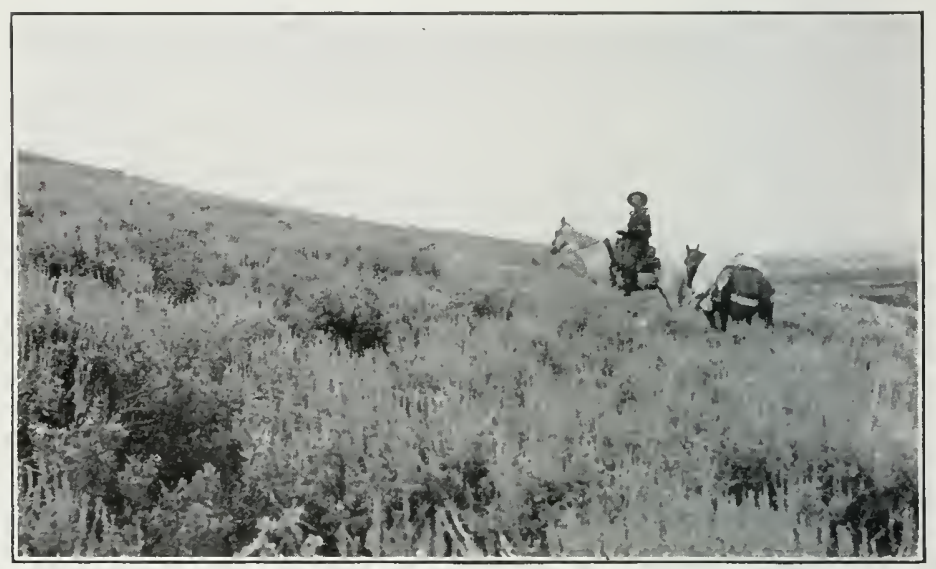

Semi-Desert Sage Range in Wyoming.

generally elsewhere and are peculiar to the Red Desert region.

The Red Desert lies generally at an elevation of 7,000 feet and consists of a high, undulating plain, broken more or less by low ranges of hills, with very little surface water and still less beneath the surface. The stock which uses this range depends almost entirely upon the winter snows for water, and therefore the region is most valuable as a winter range.

While there are some herds of cattle on this range, it is the ideal winter resort for the sheepman, and it is 
hard to say which is of the most value to the large sheepowner, the summer ranges in the momntains or the winter ranges on these deserts. The small sheepman who has his farm on which he can grow feed to winter his sheep depends more upon the summer range for a successful issue of his sheep venture. To the big owners, the men who graze their sheep by the tens of thousands, and cannot excepting in the most urgent cases be prepared to feed hay, the winter ranges are most vitally important.

These deserts are the typical sage-brush areas. Here the sage and salt bushes are almost the sole feed. There are many species of grasses and weeds but the great dependence of the stockmen, especially sheep-owners, is the sages and the varicties of the salt sage, of which Atriplex nutallii or ( $\Lambda$. volutaris) is the most common. This sage (A. volutaris) is also called tumble weed in some localities, but further south the tumble weed is Amaranthus blituides. The Russian thistle (Salsola tragus) is also commonly called tumble weed. Shad scale (Atriplex canescens) is also found in great (puantities here, together with bud or button sage (Artemisia spinescens). This latter is an especially valuable browse because of its early growth.

Sheep, especially young sheep, are apt to get sore mouths from eating this class of forage, as the spiny twigs, and in button sage the cactus-like needles, cut the interior lining of the lips and mouth. They soon get over this, however, if given a change of feed for a few days, and gradually the mouth hardens until no bad effects follow its eating.

The sheepmen range their herds on these deserts all winter, watering on snow banks whe'n no other method 
is available, and utilizing tanks and small surface lakes whenever possible. The low ranges of hills that cross the region furnish enough protection from storms, and under ordinary conditions the herds winter on this sort of feed and come out in the spring fat and healthy.

Occasionally there will be a heary fall of snow which lies on the ground for some time, and if it lasts too long severe losses result. Sometimes the snowfall is too great to allow moving the herds, and if hay cannot be hauled in to them from the railroads the herders are helpless. Unusually wet winters, which make the deserts muddy and soft, are also drawbacks which the sheepmen have to face. Fortunately these conditions are the exception rather than the rule, and generally the winters on these deserts are passed with comparatively little loss.

The Northern Range.-Strictly speaking the ranges of the Red Desert class should be included in the northern ranges, as they all lie north of the latitude of Denver, Colo., which may be taken as fairly dividing the two regions. However, when the northern ranges are spoken of it is generally meant to include those great stretches of prairie and upland country lying in Eastern Oregon, Washington, Montana, the Dakotas, western Nebraska, large portions of $\mathrm{W}$ yoming and Idaho, and the whole mountainous regions of the Rockies north of Denver.

The grasses of these regions seem to have certain fattening and growing qualities not to be found elsewhere. The steers shipped there from the South seem to spread out and gain in flesh more rapidly than if fed the best of hay.

The principal grasses are the bunch grasses of the wheat-grass group (Agropyron), prairie June grass 
(Koeleria cristata) and blue joints (Andropogon spp.). These latter species are the well-known western prairie grasses, of which $\mathrm{A}$. hallii is the most common grass in the sandhill region of western Nebraska.

There appears to be much confusion as to the use of the local names blue stem and blue joint, which are variously applied to Agropyron, Andropogon and Calamagrostis. After consultation with some of the best authorities on grasses, and carefully sifting all available information, these local names have been placed as follows: Western wheat grasses (Agropyron spp.), called blue stem from the light blue color of the leaves and stems. This is found in the Pacific Coast states and the Rocky Mountain region and makes excellent hay. Western prairie grasses (Andropogon and Calamagrostis), called blue joint from the blue or purplish blue coloring of each joint. This is found in the middle western states, Iowa, Kansas, Nebraska and the Dakotas and the prairie states generally. Most of the prairie hay put up throughout this region is blue joint. Johnson grass and sorghum belong to the Andropogon group.

All the varieties of the gramas (Bouteloua), as well as buffalo grass (Bulbilis dactyloides), are found in abundance on the northern ranges, together with every variety of edible shrub, like the service berry, mountain mahogany, sages, buck brush and that class of forage plants. In the higher mountains the same riotous growth of grasses and weeds is found as in the southern mountains, althongl alfileria, while found here, is not so abundant nor does it grow so luxuriously as in the Southwest.

Features of Northern Range.--There are several features of the northern ranges worthy of especial mention. 
The first will be found in those great high ranges of the Rockies, in most cases away up abore timber line. Catthe will seldom occupy of their own accord a range so high as this, but for developing lambs these ranges are unequaled. The season is short, seldom lasting over three months, but the green feed that comes, almost from under the retreating snow banks, is unusually good, and furnishes the ewes with great quantities of rich milk, while the little fellows quickly learn to eat the weeds and grasses of the range and grow at a tremendous rate.

In Colorado, in the vicinity of the Tennessee Pass of the Rockies, thousands of aged sheep, generally wethers from Utah, Oregon, Idaho and those states raising the heavy mutton breeds, are shipped in on the railroad by speculators on a feed-in-transit rate. They are unloaded about July 1, and on the superb feed found in those high ranges lying mostly above timber-line they put on fat very rapidly. They are generally reloaded and go forward to the large eastern markets early in September. These high ranges are for the most part so located as to be practically inaccessible except by shipping in on the railroad, hence they cannot be utilized to any extent by the local sheepmen.

The second feature is those open prairie-like areas known as parks. These are found all over the region, especially in Colorado where such splendid examples of them as the famous North Park and South Park are noteworthy. The parks lie generally at an average elevation of between 5,000 and 7,000 feet and are practically free from timber, although it surrounds them on all sides.

The grasses are mostly gramas (Bouteloua) and varieties of the wheat grasses, with much blue stem 


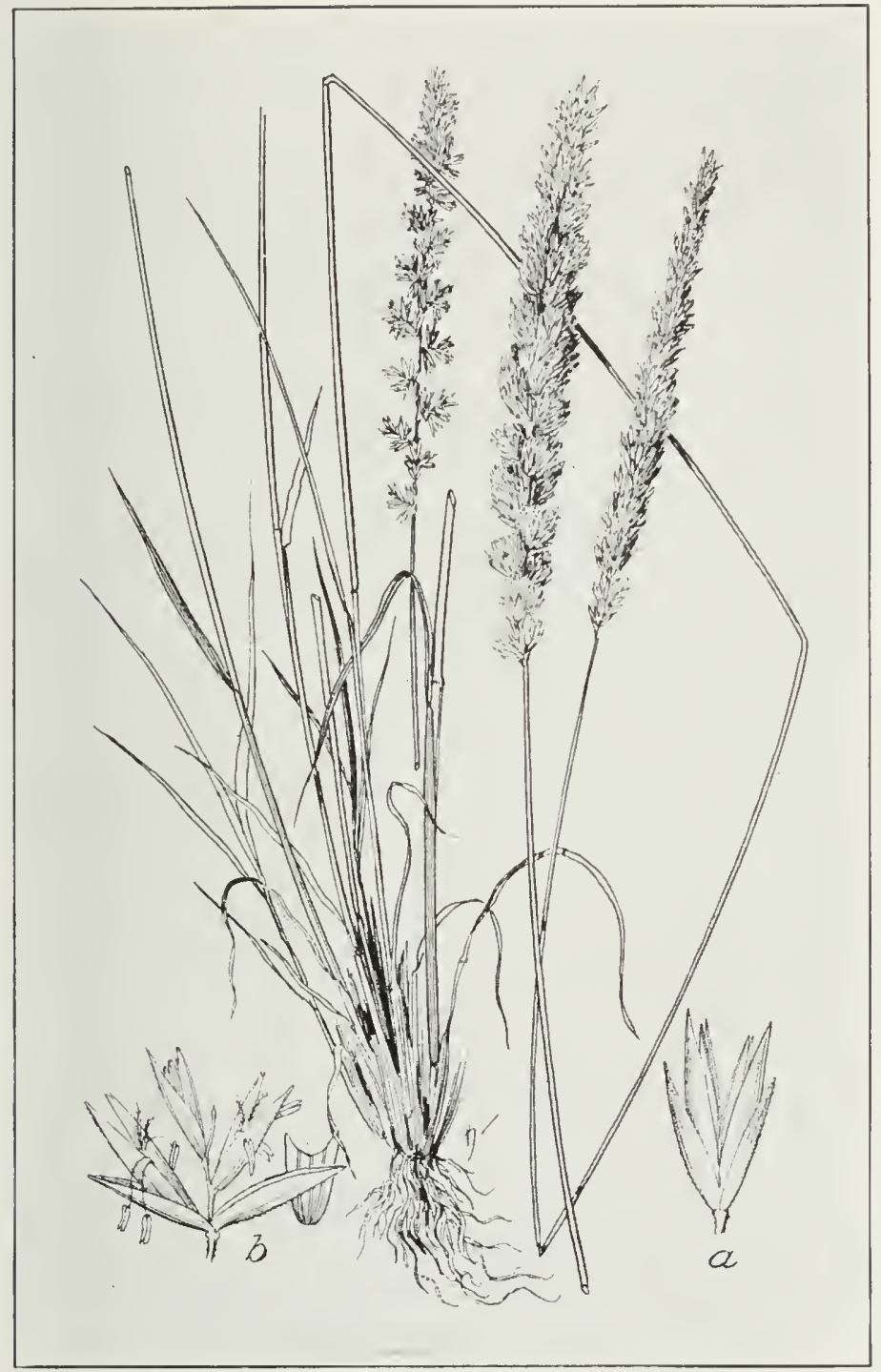

Prairie June Grass (Koeleria cristata). 


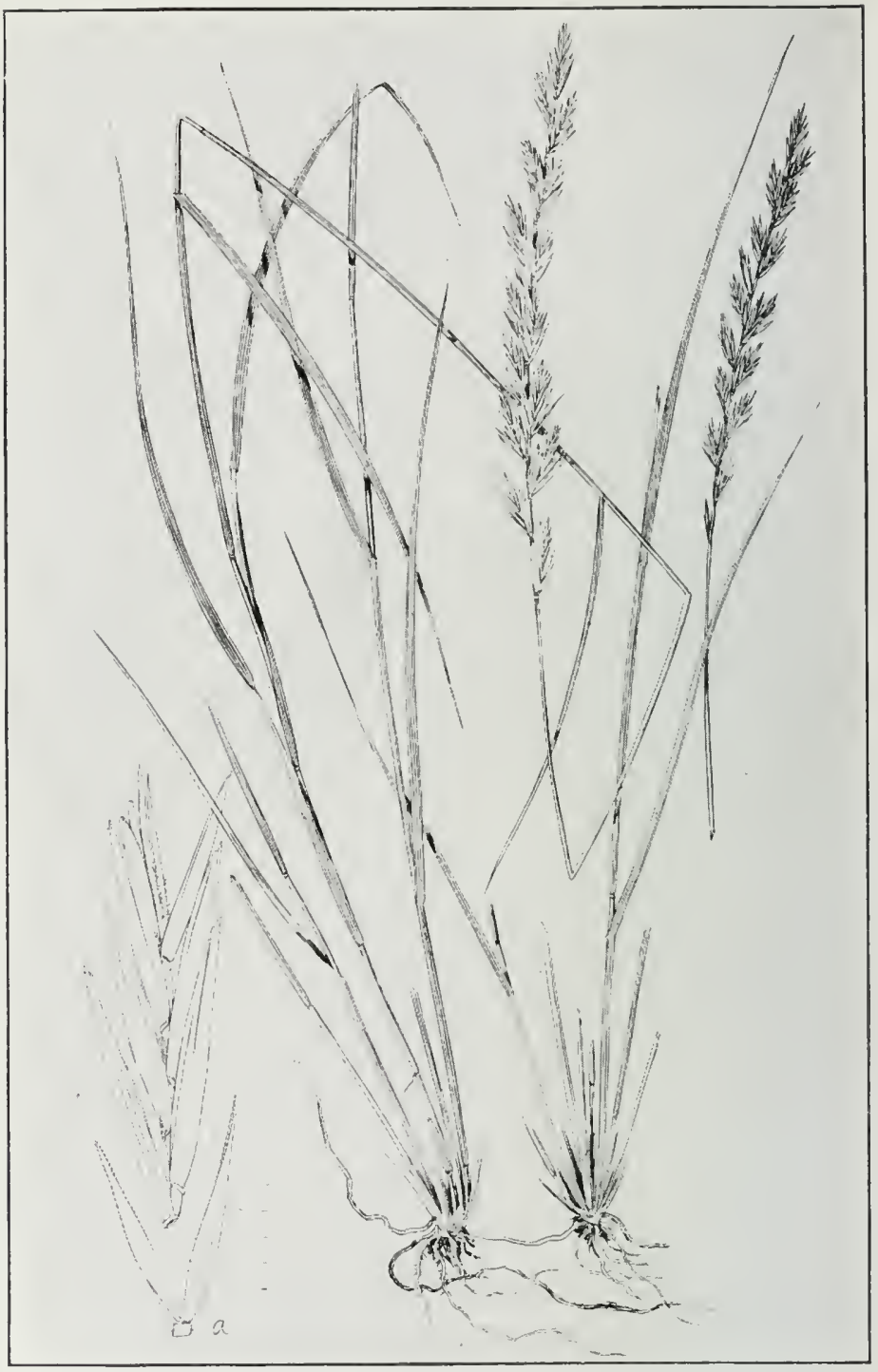

Bluestem or Western Wheatgrass (Agropyron smithii). 


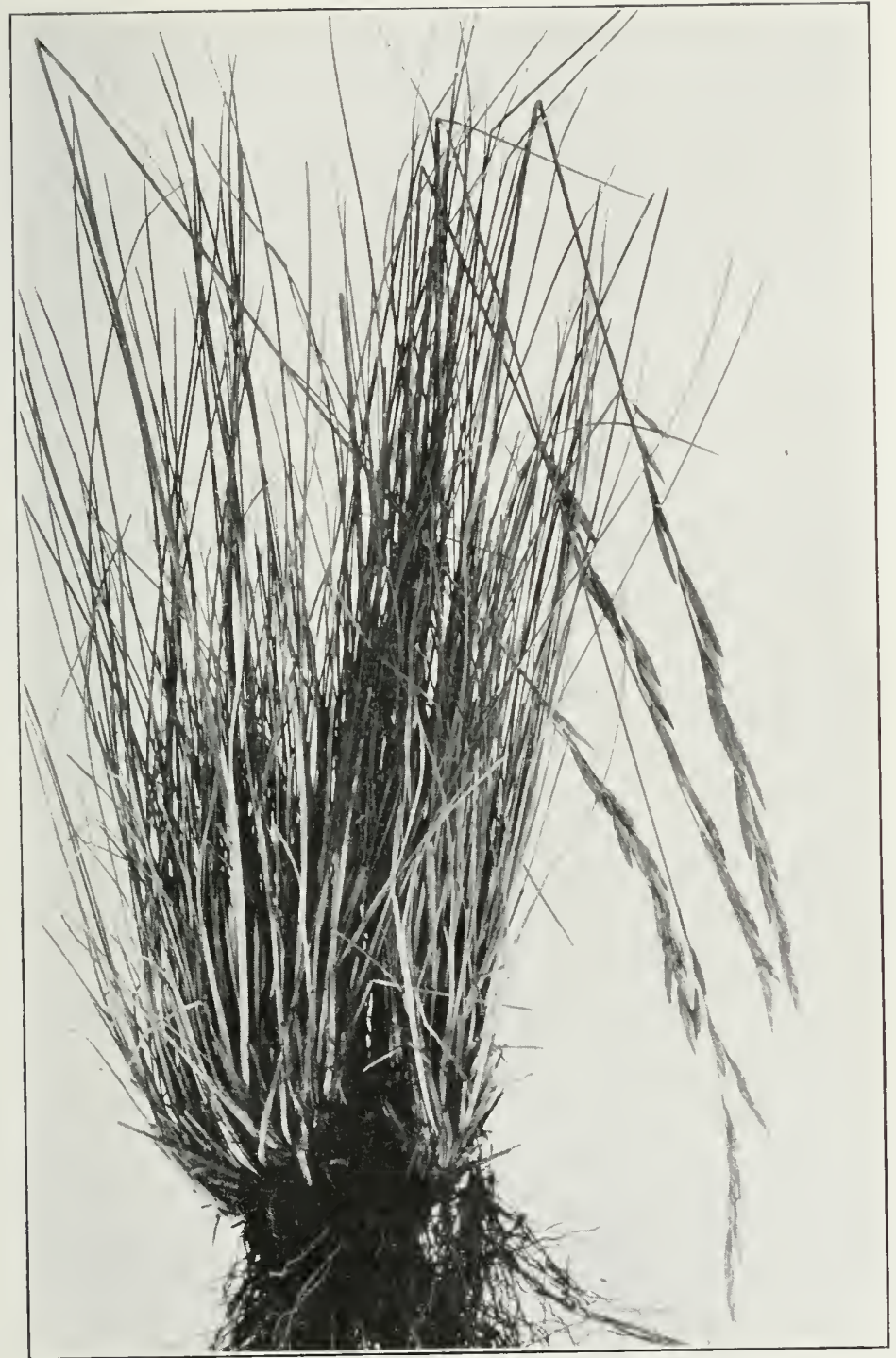

Mountain Bunch Grass (Festuca viridula). 
(Agropyron smithii), and in the northwest Mountain bunch grass (Festuca viridula), the latter seldom being found below 6,000 feet. These parks, excepting for the surrounding timber, are similar in appearance and forage covering to those great rolling prairies in the higher portions of eastern New Mexico at the upper end of the Texas staked plains.

Then we have the mountain meadows, found all over the country. These are especially fine in the higher regions of the Sierras in California. where they furnish a majority of the mountain feeding grounds. These California meadows lie at great elevations, generally over 6,000 feet and on up to perpetual snow. They are covered with a short wiry but nutritious grass known locally as short-hair grass (Calamagrostis brewerii), which will stand an immense amount of grazing without being completely killed out. This grass never grows very high but when eaten down it comes up again with amazing rapidity.

In the Rockies the feed on these high meadows is of great variety. White clover and Kentucky bluegrass (Poa pratensis) are found in abundance in the more moist places, while gramas and bunch grasses grow in great luxuriance. This together with a profusion of weeds and forage plants which seem very attractive to sheep furmishes feed for a large number of stock. Such areas should never be grazed too early, lest the cutting of the soft soil injure the ground cover and eventually ruin the entire meadow.

In some of the California mountains these meadows constitute all the stock range available. They lic in the most inaccessible places, surrounded by great granite mountains, bare of timber. To reach them the stock is 

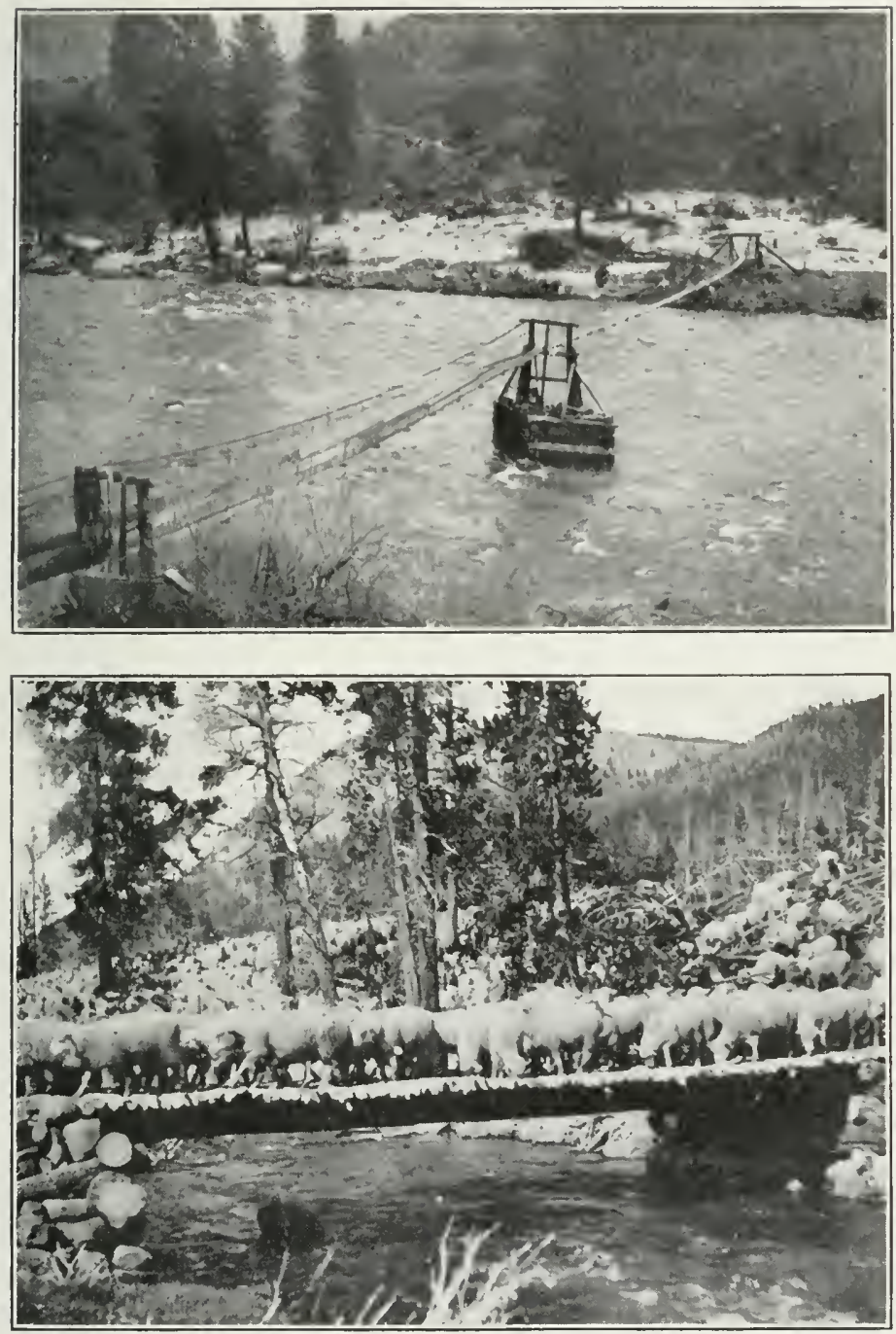

Across Swaying Bridges Above Swift Mountain Streams.-Above: Bridge Built to Cross Sheep Over the Boise River in Idaho. Below: Bridge for Sheep Across Black's Fork, Utah, Uinta National Forest. 
taken over rough trails and across swaying bridges above swift mountain streans where to the norice nothing less than a goat could be made to go. For the short time in which they can be used they support a tremendous number of stock, and the saring grace in it all is that very point-the short season. Otherwise they would long ago have been worn out and ruined beyond hope.

Spring Ranges.-In the Southwest and on the Pacific Coast they have a range known as the spring range. One of the best types of this spring range is the foothill region along the Sierras back of the great San Joaquin plains in southern California. These ranges are invaluable to sheepmen as lambing grounds, and to cattlemen for their early beef. Given a good winter with the average amount of rainfall, and early in Narch these ranges come out in the most attractive green. The feed for the most part is foxtail (Hordeum murinum), bronco grass (Bromus rubens), poverty grass (Aristida reverchoni) and of course alfileria (Erodium spp.).

None of these grasses has any great feeding value once they are ripe, careful analysis showing then devoid of fat and muscle-producing elements. But when green they are splendid forage plants and stock thrives on them, putting on fat very rapidly. The carrying capacity of these spring ranges is great. owing to the rapidity with which the plants grow when fed off. When dry foxtail is a pest, but green it is great feed. In California they say that it was originally brought into the country from Australia with a shipment of sheep. Since then it has spread rapidly: and once it takes a range no amount of grazing seems to hurt it, nor does it give way to any other plant but rather chokes out even so good 


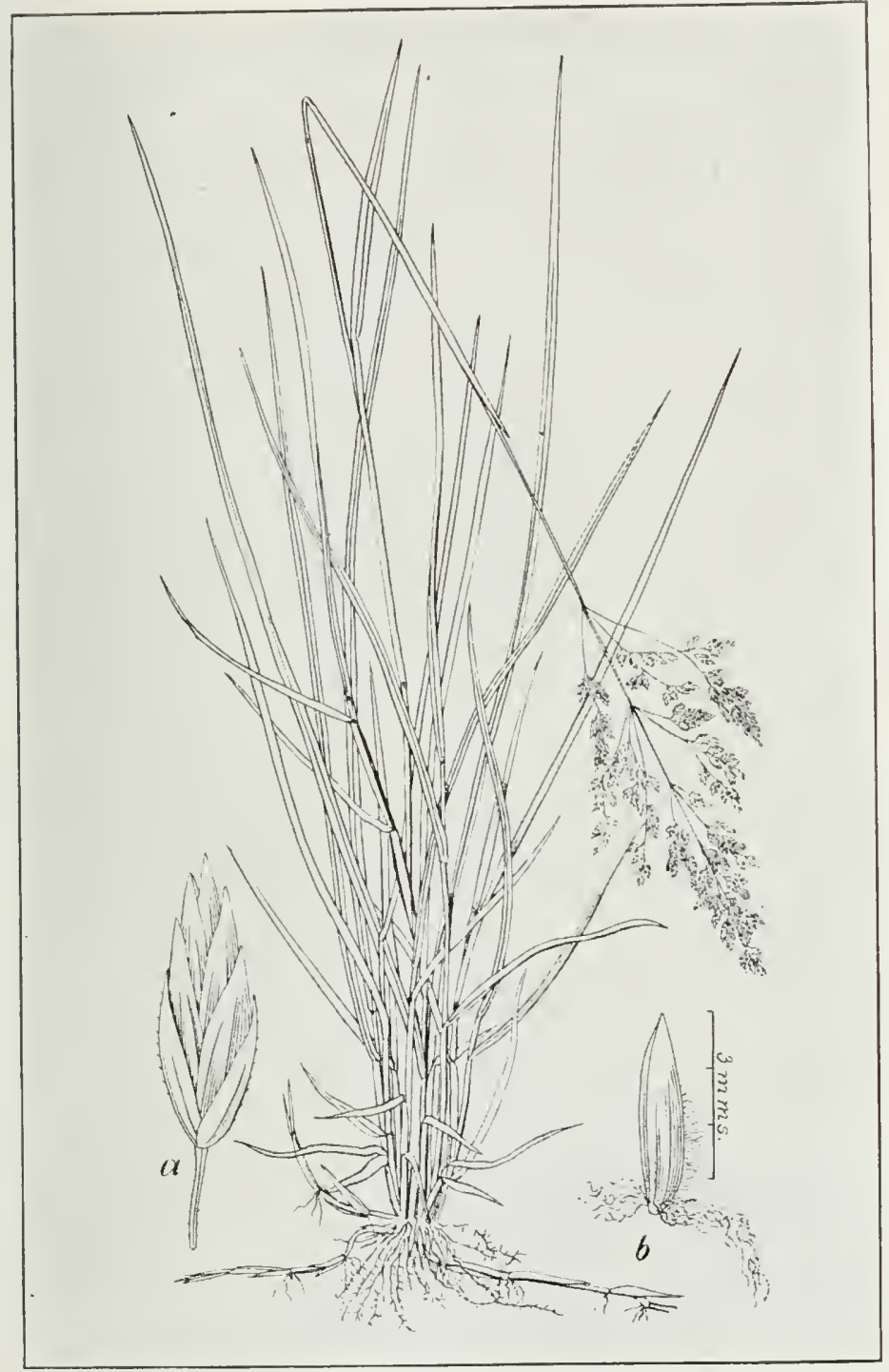

Bluegrass (Poa pretensis). 


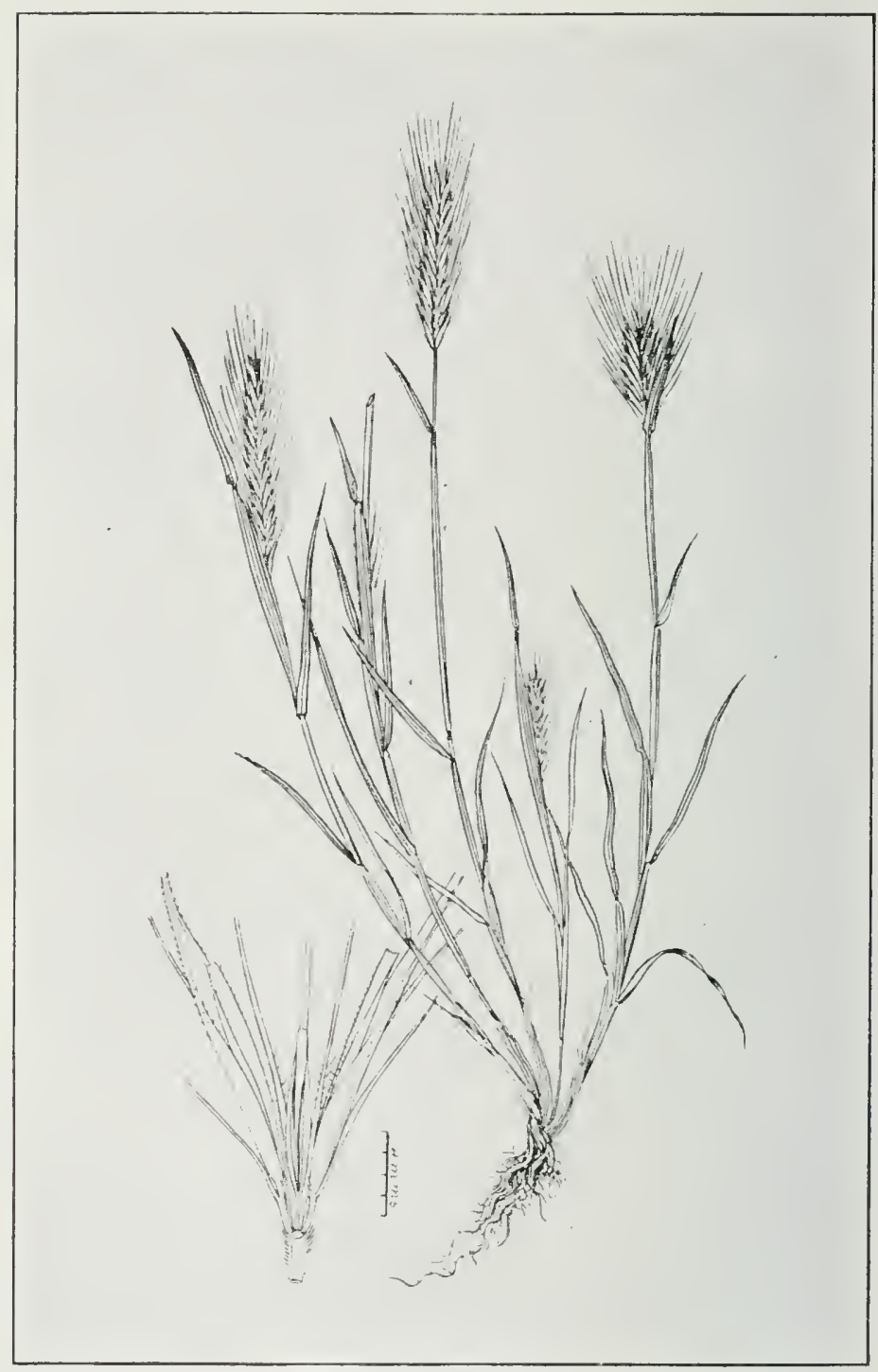

Foxtail (Hardeum murinum). 


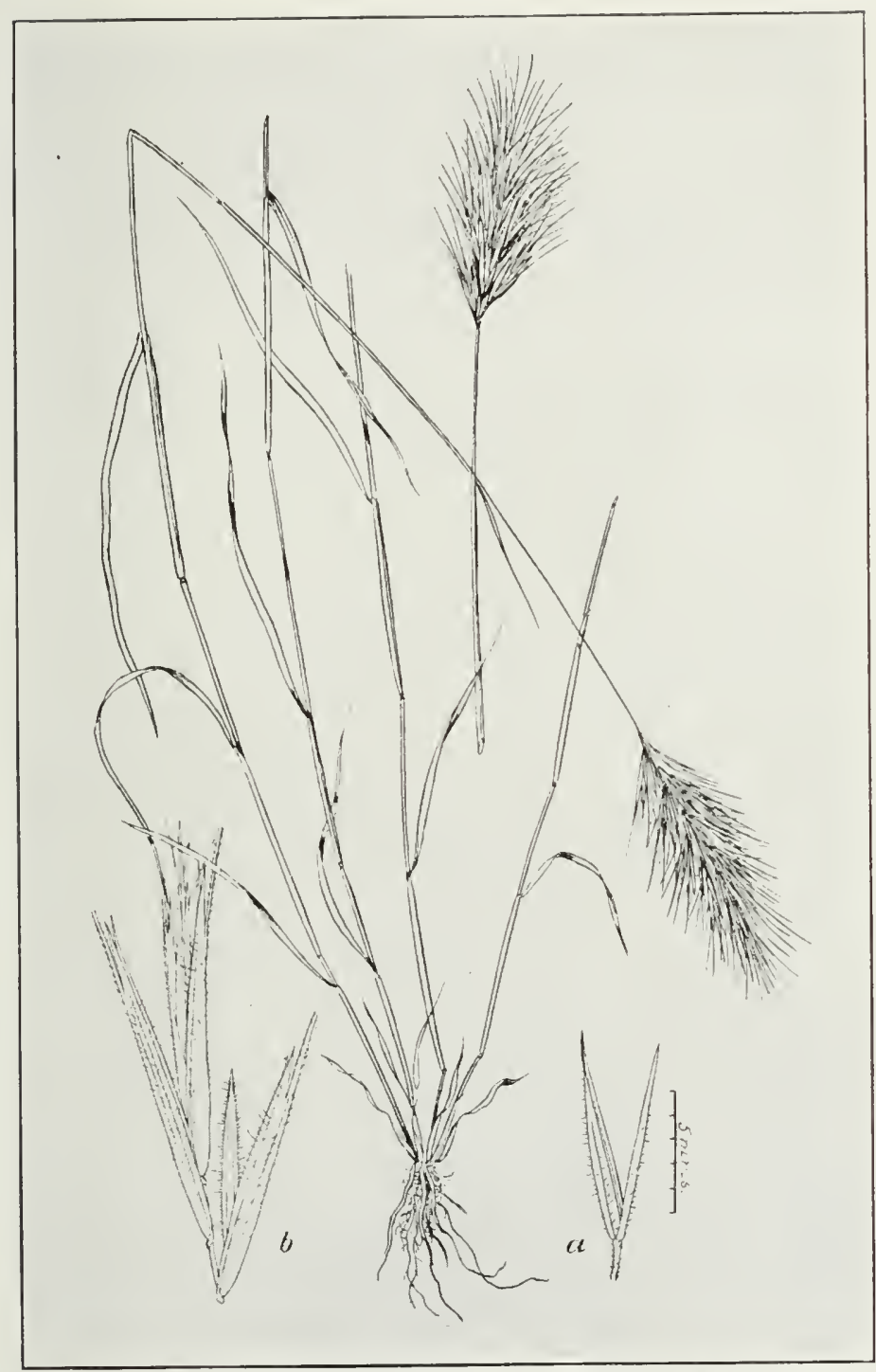

Bronco Grass (Bromus rubens). 


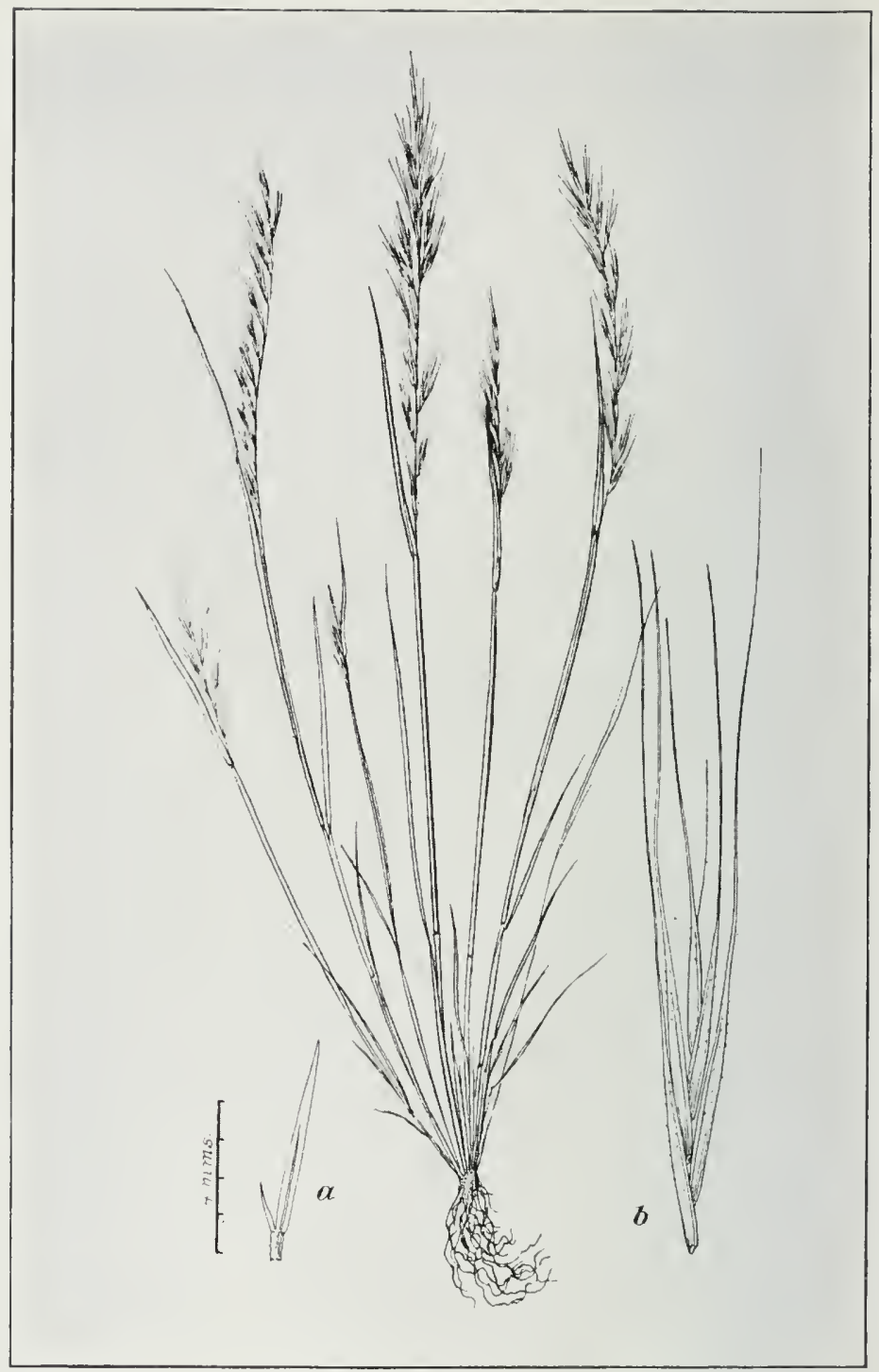

Festuca myuros (sometimes called Poverty grass). 
a grower as the alfileria. This is noticeable on the San Joaquin plains, where in the last fifteen years the oldtimers say it has almost completely run out alfileria on some ranges.

These spring ranges come quickly and go as rapidly as they came. Py the end of June they are dry and yellow, and the feed is gone for the season.

Carrying Capacity of Ranges.-It is impossible to give any hard and fast rule for estimating the carrying capacity of the western ranges. Much depends of course on the character of the soil, the annual rainfall and the slope of the country, whether to the south or the north. A range facing to the south and east will generally be two to three weeks earlier than one which lies to the north or west. Also the kinds of forage plants found upon the range must be considered, as well as the watering facilities for the animals that are to use it.

Horses the Worst Grazers.-Based upon their use of the range, horses are the worst grazers we have. This is due to their habit of traveling long distances to water and feed, often at very ligh speeds. their playfulness on the range and the fact that a horse can and does graze a range very closely, possibly even closer than a sheep. A bunch of horses in good spirits will race and romp over the range for hours at a time. cutting up the sod with their feet, chasing the cattle away from the water holes and salting grounds, running over little calves and in this manner often doing more clamage than they do br feeding. A stockman taking horses for pasture will charge more for that class of stock than for anv other. and nu account of it some will not receive them for pasture at all.

Nules also do great damage among stock on the 
range, chasing little calres and colts until they drop down exhausted, when the mule will perhaps trample them to death. This I have seen happen over and over again on western ranges where the Mexicans and Indians raised a great many mules. The mules unquestionably do this in play, but the effect on the young things is quite as bad as if clone with malicious intent. In some regions where owners have persisted in turning out mules to graze on the ranges, owners took the nutter into their own hands and the animals were killed as a matter of protection.

Range for Cattle. - Tn estimating the carrying capacity of a range, it is generally agreed that a fair ratio between cattle and sheep is one to five: that is, a range which will strpport one cow will support five sheep. In feedlots it is generally admitted that the same amount of feed which will support one cow will take care of eight sheep. This is due of course to a closer cleaning up of the feed by the sheep.

On many of the desert ranges it will probably require 100 acres to the animal to carry cattle the year around, while in the mountain ranges, where feed grows rapidly and there is a great variety of it, probably ten to fifteen acres is sufficient. In Texas on the staked-plains ranges they estimate that nne cow or steer will require ten acres for year-around purposes. while on the eastern New Mexico ranges, where the sod is not so good. twenty-five to thirty acres are necessary to keep the range from being overgrazed and damaged. This is of course for year after year. In some seasons, due to $11 n-$ usual precipitation, the feed grows so fast and there is so much of it that a cow to every five acres will not begin to eat it off. 
On the pratries of Western Katlsats and Nebraska they estimate that for year-around purpuses between fifty and sixty head to the section ( 040 acres) is about the right number to keep the animals in good flesh and not overgraze the land. If used only in the summer season when the feed is growing rapilly the carrying capacity is greater than these figures indicate.

On the sheep ranges in the higher monntains of Utah, Idaho and the rest of the Rocky Mountain states during the summer season, which is short-not over four months on an arerage-the ranges will and do carry as many as a sheep, to the acre without being overgrazed. As a general thing, however, a sheep to every $21 / 2$ acres is the safest rule. This of comrse must vary with the quality of the range.

Goats eat so much brush that it is almost impossible to make a fair estimate of the capacity of a goat range, tuless one goes over it carefully and notes the stand of the brush.

The accessibility of water is also a great factur. because if stock must travel long distances to and from water it not only tramples out a certain amount of feed but takes time which shottl be used in grazing. One of the best ways to estimate the capacity of a range is to take a look at the stock at the end of the grazing season. Fat sheep and cattle will not be found on an overgrazed range. The instant they are foreed to graze the feed closely, and take the rugher and unpalatable portions of the forage, that instant they begin to fall off, and if kept there for any length of time both stock and range will tell their own story.

There are many grasses and forage plants which stock will not graze closely. some which they will 
only graze when young and tender, and some which look to be good feed but which nothing will touch. Thus if one looks only at the amount of feed left on the range, unless he is well acquainted with that particular range and its grasses, he may be misled. Sheep are great weed-eaters. The Minnesota experiment station found that out of 480 weeds in that state sheep ate no less than 430 of them. This fact should always be taken into consideration in looking over ranges, because a range may have very little grass and still be a splendid sheep range.

In handling sheep it is well to remember that 1,000 ewes and their lambs will not do so much harm to the feed and range as 1,000 dry ewes or wethers. The latter classes roam about, do not graze quietly and generally graze in closer formation, thus wearing out the range more than the ewes and lambs do.

The fact that a certain area will support 1,000 sheep or 500 cattle for six months does not mean that it will carry twice that number of either kind for half the time. The growth of the feed during the grazing period is overlooked if this be done, as well as the natural trampling due to overcrowding. 


\section{CHWPTR II.}

\section{COMING OF THE SETTLER.}

Coming of the Settler.- IVith the cluse of the ciril war the settlement of the region west of the Mississippl and Missouri rivers really began in earnest. The preemption law of $18+1$ and the homestead law of 1862 uffered great inducements to men to move out onto the prairies and take wp homes. Later on came the various soldiers" scrip laws, which gave to veterans of the war a certain amount of land without residence of any great length of time or other delays.

Extension of Holdings.-Still later came the timber culture bill and the measure for settling up desert lands, known as the desert land law, which allowed every person an additional $6+0$ acres, making a total of about 1,200 acres of land which under the law one man could legally obtain from the government. liesilles these the stone and timber act, the various land and serip laws and the mining laws offered any one all the land he conld afford to buy at a very low price, seldom above $\$ 2.50$ and much of it at $\$ 1.25$ per acre.

Displacing Stockmen.-The whole West was practically before them. The stockmen who were the pioneers in the comntry had done very little towards obtaining permanent homes, contenting themselves with taking up a ranch here and there, which offered a good 
point for establishing a headquarters camp or cutting hay for winter feeding. Is a general thing, however, they scorned a permanent home, and as fast as the settlers came into their neighborhood crowded farther and farther out into the almost nuknown land ahead of them.

I well remember in 1885 the disgust which fell upon my own outfit, then located wpon the Little Colorado River in northern Arizona, over the advent of a neighbor. Our nearest had been twenty-five miles distant, and the newcomer had the temerity to turn loose 1,000 head of west Texas heifers at a point fully twenty miles above us. Our own cattle seldom wandered more than five miles away from the rough camp where we had established ourselves. Between us and the new neighbor was an almost untouched stretch of grass land, and back of us lay a virgin country fifty miles wide with not a settler or a domestic animal on it. Nevertheless, we felt much aggrieved at the nerve of the newcomer to crowd in on us in that fashion, and for several months there was a hostile feeling between the two outfits. As the newcomer had been squeezed out of his Texas ranges by nesters, our lack of cordiality made no impression whatever upon him.

This was the beginning of the end of our deliglitful isolation, and we lived to see stockmen's cabins at every water hole and available location all over the country. Where we had felt crowded by 2.000 cattle, 50,000 were hunting grass and water on the same range a few years later. And our case was typical of what was happening all over the range country.

Early Settlers in the Great Plains Region.-While the stockmen were neglecting their opportunities the 


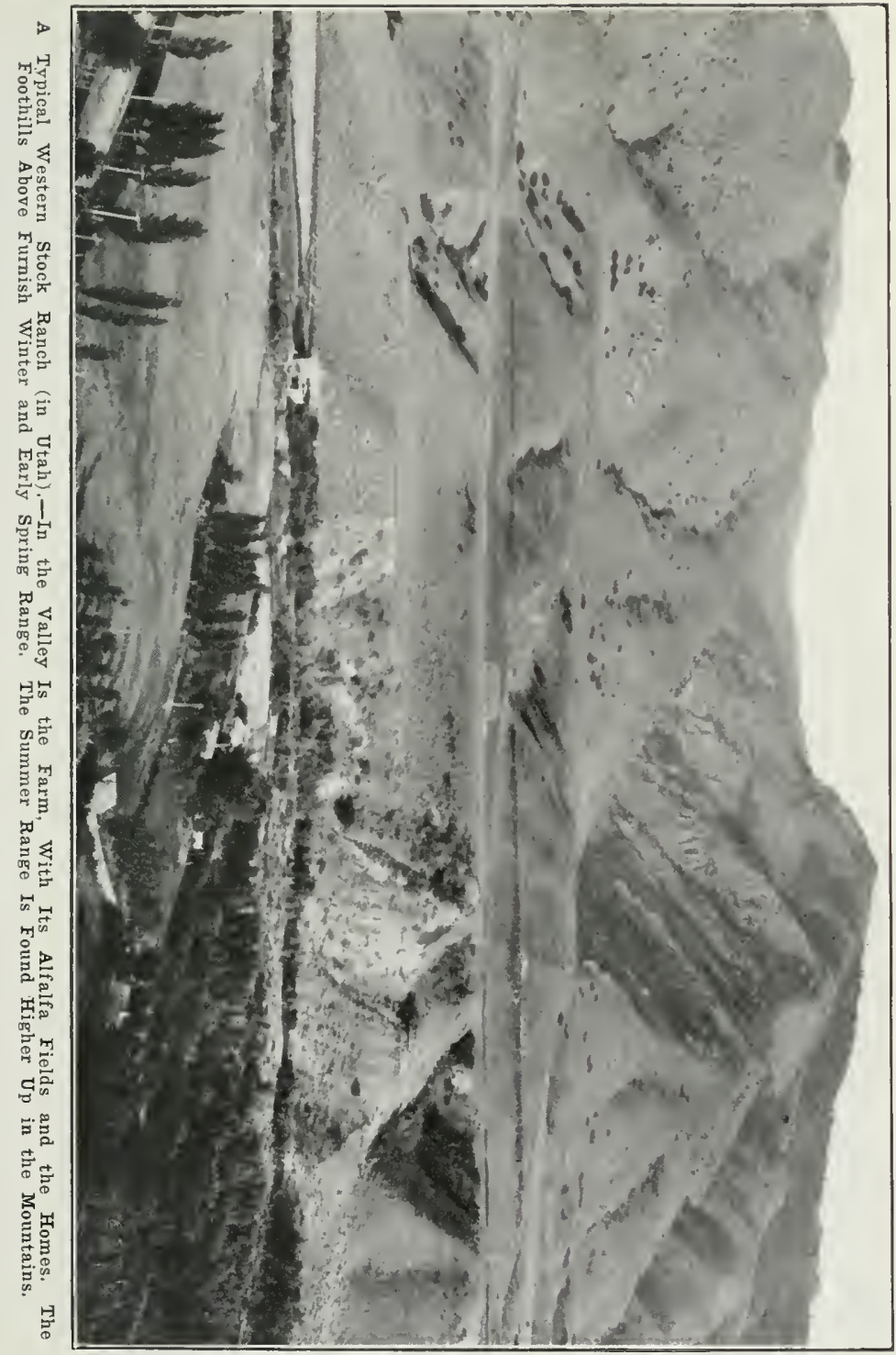


farming class of settlers were working westward into Kansas and Nebraska, following up the streams where the rich bottom lands offered splendid returns to the agriculturist. For many years the higher lands or nllesas (from the Spanish nleaning table) lying back from the streans were passed by and allowed to remain for the open range of the stockmen. Gradually the available locations along the streams were taken up and the newconers tried farming on the higher benches back from the bottom lands, while the line of settlers worked farther and farther west out into the region where the rainfall was nuch less.

For a series of years they raised great crops all over this region. Then came a setback through drouth that extended over several years. Not being prepared to face such a condition they were forced to abandon their farms, and from about the line of the 97th Meridian west almost up to the foothills of the Rockies they practically deserted the country en masse. The land went back to the stockmen and the tide of westward emigration stood still for several years.

Meantime, in some parts of the Southwest, in Arizona, New Mexico and Colorado, the California method of irrigation was gaining a footing. Thin lines of settlements were working up the various little streans whose waters were taken from them through ditches and poured upon the thirsty land. In northern Arizona the Mormons established themselves at several points, surmounting obstacles that no other class of people on eartlı could have successfully overcome.

All that great comntry along the Arkansas River in VTestern Kansas and eastern Colorado was then considered as the very cream of the open range. Thousands 
upon thousands of cattle and horses ranged over those broad prairies, watering at the river and grazing back over the prairies for miles upon each side of it. Then the settlers began to creep up its borders and gradually the stockmen found their watering places fenced up, and where once there had been miles upon miles of open water along the river they found their cattle turned back by the farmers' fences.

This was the beginning of the end, for about that time the effect of overgrazing began to tell on the carrying capacity of the ranges, and one hard winter literally swept the country bare of stock.

The Settlers' Second Attack on the Arid Regions.-A few years later, encouraged by a series of wet years, the farmers again took up their attack on the desert and slowly began to force their way westward. The class of men who came this second time were better prepared to meet the vicissitudes of desert farming and had sufficient means to meet a few bad years. Fortunately for the country, as well as their own future, there followed a decade of splendid years. The line of farms worked steadily westward until the little town of Hutchinson, Kans., which at one time was considered in the very heart of the desert, was left far behind.

Ask any old-time farmer what made the change, and he will promptly assure you that the climate has changed. He will declare that it rains more than it used to and that there is not so much wind as formerly, all of which he believes accounts for the success of the farmer in the desert. However, the weather records kept for forty years at Fort Dodge, Kans., and almost as long at other western army posts, prove conclusively that taken by ten-year periods there has been no appreciable 
change in the rainfall or other climatic conditions anywhere in the West.

Success of the Settlers.-The success of the whole thing lay in the fact that with the second attack the settlers had a series of years in which the rainfall was unusually regular. This gave them time to get established in some comfort. When a series of dry years came they had the soil in such condition that it returned them good crops with much less rain, while even if the crops failed for one year they had saved up surplus enough to carry themselves and their live stock through a year or two of shortage.

The Department of Agriculture did much to help the settlers in this work by hunting the world over for drouth-resistant plants of all kinds. From Russia and other regions they brought new species of wheat and other grains that were accustomed to grow with a minimum of moisture. On the steppes of Russia it found an alfalfa that grew anid the most inhospitable conditions of cold and drouth. This work was also of great value to the dry-farming raid on the desert lands which came a few years later.

Then came the great growth of the beet sugar industry all over the West. Huge irrigation works were planned and carried out wherever there was a stream available. Western Kansas and eastern Colorado made especially great strides in these respects. In the Northwest in Montana, Idaho, Utah and the two Dakotas, between the growth of the sugar industry and the growing of wheat on lands that had always been supposed to be worthless for any purpose whatever except grazing, the settlers swarmed over the land.

All these things spelled finis for the range stock busi- 
ness. The Dakotas, which at one time were the greatest of the open range states, practically ceased to be factors in it. This also held good on large areas of the other states, although few of then became so completely possessed by the "man with the hoe" as the Dakotas. In the meantime the same process had been repeated on the Pacific Coast. The Sierras offered a barrier to the settlers in California, but they pushed up the coast and worked their way eastward into Oregon and Washington, over the tips of the Cascades and out onto the great sweeping prairies of eastern Oregon.

The Mormons. - With their oasis at Salt Lake City for a headquarters, the settlement started on the margin of the great Salt Lake in 1847 by the Mormons was slowly spreading out, fecling its way cautiously. Once a foot was planted they never turned back nor abandoned their position. Down into Arizona on the south, and north into Idaho, pressed these desert fighters of Brigham Young. Alone and muaided they faced and solved some of the nost difficult problems that the newcomers in any country have been called upon to meet.

The Nesters.-One peculiar class of western settler was the nester. As the stock-raisers opened up the country the water question soon became important, and locations on creeks and other streams, springs and water holes began to have a decided value. Ordinarily the larger outfits made locations in various ways, so as to cover these watering places upon the more important parts of their range, with a view to spreading out their holdings in such a way that through their control of the watering places the surrounding range would naturally be left to their stock. Through dummy locators, land scrip and many other methods, some legal and others at 
least questionable, such locations were spread over as large a country as possible. Still it was not always practicable to protect every place.

The nester, alive to this fact, dropped down into the middle of the range at some unimportant water hole and unloaded his goods and chattels from his covered wagon. Possibly he filed a bona fide location upon the place; more often he did not. In any event, he had several months in which to perfect his filings before he could be removed legally, and meantime in most cases he was there simply to harass the stockman. Little patches of ground were plowed up with a pretense of farming and a crop was planted. The range cattle would break through the ramshackle fence which had been placed about the so-called farm and immediately a damage claim was instituted.

Motherless calves were picked up and branded by the nester, whose sole claim to them was through the possession of a team, possibly a couple of milk cows, and the ownership of a brand, which was seldom legally recorded. His dogs fought off the range cattle when they came for water, and more often the water itself was fenced in. The final coup de grace by such an individual was a threat to sell out his claim to some wandering sheepman.

In every possible way the nester was a thorn in the side of the stockmen, especially the cattle outfits. If his claim was purchased merely to get rid of him, he generally moved along onto some other range, and repeated the proceedings. The nester was responsible for an immense amount of hard feeling between the cattle and sheep interests, as well as more or less bloodshed througl attempts to get rid of him and his kind, by evictions a1 the muzzle of a Winchester. 
The Dry Farmers.-During the past few years a new type of settler, the dry farmer or "kafer corn-er," as he is often called, has worked great changes in the western ranges, especially in the Great P'lains region lying east of the Rocky Mountains. Through this broad strip, which is probably 200 miles wide and extends from the Canadian line on the north down into the Texas staked plains on the south, the annual rainfall of about 18 inches is sufficient to admit of dry farming, or farming without irrigation, if carried on under certain well-defuned principles.

While the dry farming scheme is not altogether of recent origin, having been practiced for many years in certain portions of the arid region, it attracted but little attention until a few years ago. Partially under the impulse of land-booming agencies, this new system of farming was brought prominently before the public. As the areas on which it could be applied were large and open to settlement under Government laws, the land-hungry people eagerly took up the idea. The Panhandle of Texas was the scene of the greatest development, and in an incredibly short time thousands of settlers secured homes on land that had been previously classed as fit only for grazing purposes. Aided by a series of unusually good years they grew crops the equal of anything possible by irrigation. Niles and miles of prairie land were broken up by farmers, most of them well-to-do eastern men, who brought with them not only their horses, cows and household furniture but money enough to carry them over the first few years.

Under such conditions the changes that came over the land in the dry-farming regions were remarkable. Little hamlets grew into towns, towns into cities, and 
where only the sheep-herder or cowboy had lately reigned, every quarter-section had its house. Miles and miles of wire fences closed the ranges up to stockmen, and thousands of cattle and sheep were forced to leave the regions which they had used for years. Many of the larger outfits, seeing the inevitable, sold their stock and left the country in disgust. Many who had bought large tracts of land, especially in Texas, found their land far too valuable to retain for cattle-raising, so after shipping out the cattle they divided their holdings into small tracts, which were eagerly snapped up. Land that had for years gone begging at $\$ 1$ to $\$ 2$ per acre was held at $\$ 20$ to $\$ 40$ per acre.

The dry farmers poured over into eastern New Mexico, where the conditions of land and rainfall were the same as in the Panhandle, and drove the stockmen from their ranges in that region. $U_{p}$ through eastern Colorado into Wyoming, Montana and Utah the same conditions prevailed, and the end is not yet.

That total failure was prophesied by all the oldtimers in the West goes without saying. That there has so far been no general failure is an honest fact. Here and there failures have occurred, due to spotted rainfall, and a total disregard of the true scientific principles underlying the dry-farming theory. Generally speaking, however, all over this dry-farming region the principle has worked out in a highly successful manner, and unquestionably the dry farmer is here to stay, and must be reckoned with in the future as an additional producer of stock and farm products. 


\section{CIIAPTER IV. \\ LIVE STOCK ON THE RANGE.}

Live Stock on the Range.--On January 1, 1913, there were in the United States, according to the Government statistics, 56,527,000 cattle, 51,482,000 sheep, 20,567,000 horses and 4,386,000 mules. The total value of these animals was over $\$ 4,357,000,000$. In the states that lie west of the Missouri River, and which may be classified as range states, namely, Washington, Oregon, California, Idaho, Nevada, Utah, Arizona, New Mexico, Colorado, Wyoming, Montana, South Dakota, Nebraska, North Dakota, Kansas, Oklahoma and Texas, the total number of stock Jan. 1, 1913, was as follows: Cattle, 23,218,000; sheep, 32,12+,000. The state of Texas stands at the head of the western cattle states with a total of 6,056,000 head, while Montana, with 5,111,000 sheep heads the list of sheep-owning states, Wyoming coming next with $4,472,000$ head.

Live Stock in Western States.-The figures on the following page taken from the government reports showing the number of each class of stock in the various range states on Jan. 1, 1910, and on Jan. 1, 1913, may be of interest to students.

Of the eastern states little Rhode Island has 7,000 sheep and the great corn-growing and cattle-feeding state of Iowa has $3,944,000$ cattle. A net reduction of 
almost seven million cattle in these states in the three years is a ready answer to the question of why beefsteak is so high.

\begin{tabular}{|c|c|c|c|c|}
\hline \multirow{2}{*}{ State. } & \multicolumn{2}{|c|}{ Cattle } & \multicolumn{2}{|c|}{-Sheep- } \\
\hline & 1910 & 1913 & 1910 & 1913 \\
\hline 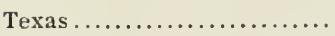 & $8,268,000$ & $6,056,000$ & $1,909,000$ & $2,073,000$ \\
\hline Montana.................. & 922,000 & 812,000 & $5,747,000$ & $5,111,000$ \\
\hline Wyoming........................ & 986,000 & 542,000 & $7,316,000$ & $4,472,000$ \\
\hline Colorado................... & $1,586,000$ & $1,093,000$ & $1,729,000$ & $1,737,000$ \\
\hline New Mexico .................. & 930,000 & 947,000 & $4,729,000$ & $3,330,000$ \\
\hline Arizona...................... & 651,000 & 812,000 & $1,020,000$ & $1,570,000$ \\
\hline 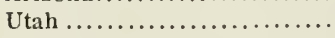 & 415,000 & 437,900 & $3,177,000$ & $1,990,000$ \\
\hline Nevada .................... & 423,000 & 453,000 & $1,585,000$ & $1,487,000$ \\
\hline Idaho....................... & 421,000 & 442,000 & $4,248,000$ & $2,951,000$ \\
\hline Oregon...................... & 872,000 & 639,000 & $2,581,000$ & $2,644,000$ \\
\hline California .................. & $1,572,000$ & $1,964,000$ & $2,372,000$ & $2,603,000$ \\
\hline Washington ................... & 563,000 & 405,000 & 783,000 & 501,000 \\
\hline North Dakota................ & 863,000 & 714,000 & 621,000 & 293,000 \\
\hline South Dakota............... & $1.996,000$ & $1,278,000$ & 829,000 & 593,000 \\
\hline Nebraska .................. & $3,919,000$ & $2,509,000$ & 393,000 & 382,000 \\
\hline Kansas................... & $3,997,000$ & $2,476,000$ & 278,000 & 316,000 \\
\hline Oklahoma.................. & . $1,992,000$ & $1,639,000$ & 108,000 & 71,000 \\
\hline & $\overline{30,376,000}$ & $23,218,000$ & $39,425,000$ & $32,124,000$ \\
\hline
\end{tabular}

Short-horns on the Range.-In the early years of the western range business Short-horns, then called Durhams, were the predominant breed. The long-horns from Texas could not be classified under any particular breed or kind, but were probably descendants of the Spanish cattle brought originally into old Mexico from where they spread to the Texas ranges. There they were bred up mainly by the use of Short-horn bulls. So long as the ranges were virgin and grass was plentiful, the Short-horn breed flourished and held its own.

The Devon was raised to some extent, the Mormon people who went west taking a large number of Devons with them. For years many of the herds in Utah and those places where the early Mormon pioneers gained a foothold showed the cherry red of the Devon blood very plainly. As the ranges were filled up with stock and 
feed became scarce, the Short-horn was found deficient in those rustling qualities which were an absolute necessity where animals were allowed to fight for their lives in the snows of winter and the drouths of summer. The Short-horn in such circumstances lost much of its

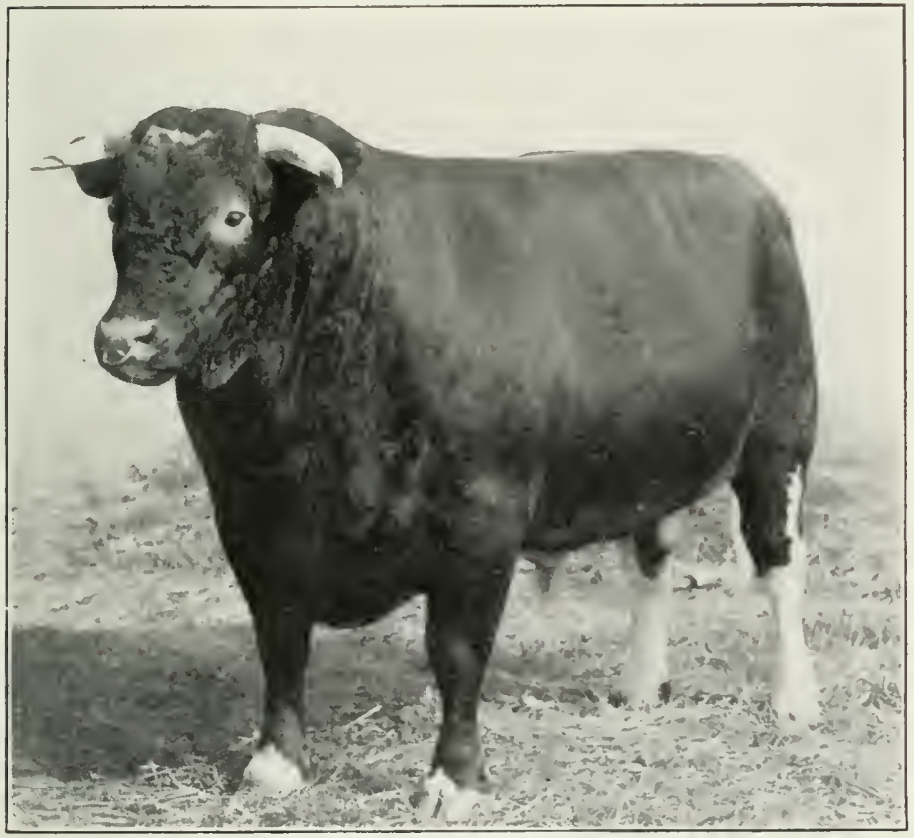

Type of Short-horn Bull.

vitality and stamina and it was soon found that a hardier breed must be used for the open range.

The Advent of Herefords.-Then Herefords began to make their appearance, and with their unrivaled rustling ability, their prepotency (which shows in the white faces of the calves, no matter how low the grade 


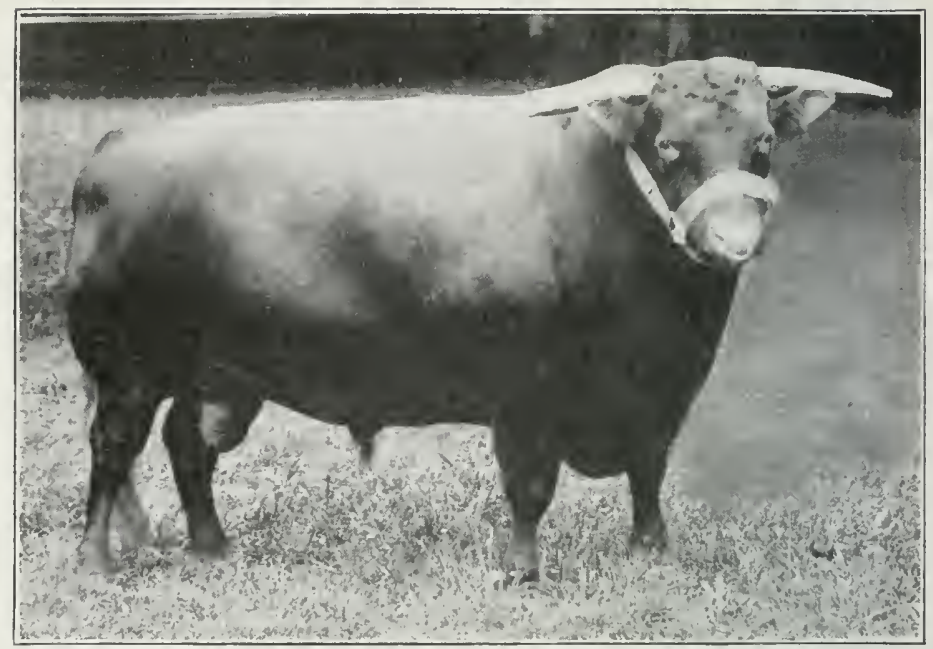

Type of Devon Bull.

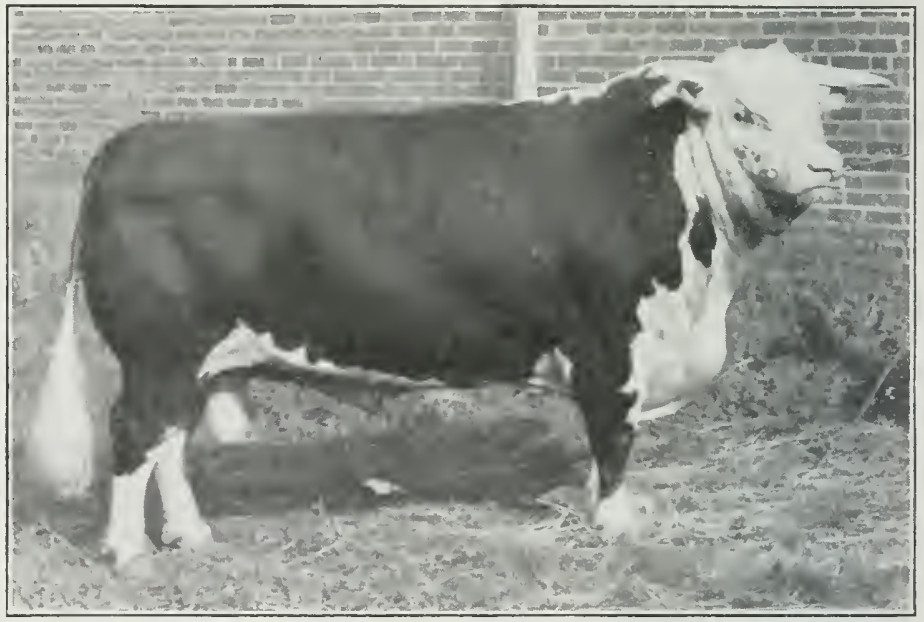

Type of Hereford Bull. 
may be), and their early-maturing (fualities, fuickly becance prime favorites. Torlay there is practically but one breed of cattle used on the open ranges; that is the llereford.

The Polled Angus, now called Mberdeen Angus, and Galloways were tried by the western rangenen, and for a time it was believed they offered cattle that would

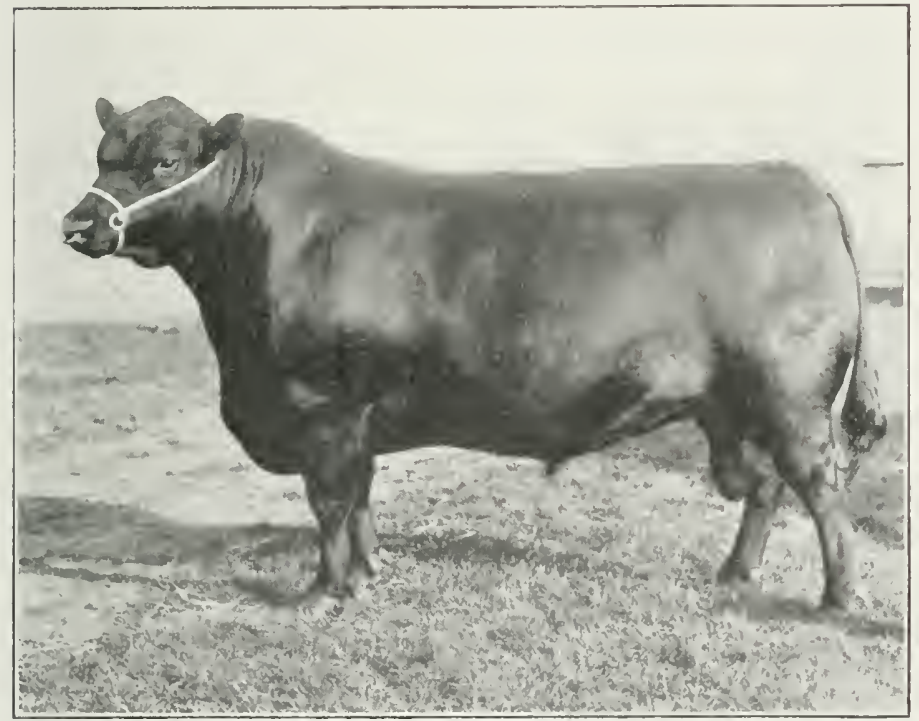

Type of Angus Bull.

be superior to every other kind. A few years of experience, howerer, modified this riew. They were hardy enough, excellent rustlers and with their good coats were able to withstand hard winters. For some reason, however, the bulls did not breed well under open range conditions, and as a rule the calf crops from these animals were too light to make either the Galloway or the Angus a profitable breed. 
Handled in small bunches and under fences the "blacks" do well, and the steers are highly prized for their feeding qualities.

There is a tendency in the Hereford blood, unless often changed, for the cattle to lose size, become narrow in the hips, drawn up in the flanks, heavy in the necks and shoulders and to develop staggy horns. The most successful of the western cattlemen, after using Here-

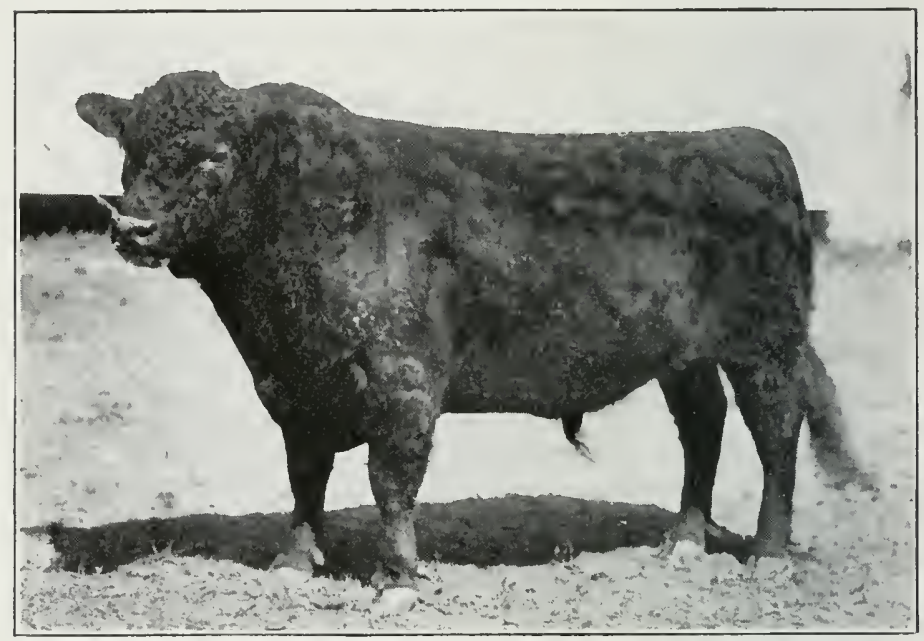

Type of Galloway Bull.

ford bulls for six or eight years, have put the very roughest big-boned Short-horns they could procure into their herds for a couple of years in order to widen the cattle out and check the tendency toward narrowness.

When the Hereford bulls are again used the calves resulting from this cross are very superior feeding steers, wide of hips, thin of neck and with well shaped heads and horns. The clear white face of the Hereford is 
lost by the infusion of Short-horn blood, showing in the "brockle" faces of the young stock.

Early Horses of the Plains.-When the early Imerican explorers first saw the western plains they found besides the buffalo and game animals great herds of wild horses. Capt. Zebulon Pike, the bold American officer who in 1806 toiled up the banks uf the Arkansas River clear to its source. writes of their presence on the great plains, and other explorers hefore him also tell of them. IVhen Coronado, the Spanish explorer, worked his way eastward in $15+5$ onto the grassy prairies of eastern New Mexico, western Lansas and the Texas Panhandle, he found the Indians using dogs for moring their camp plunder. The dogs were packed with burdens and also dragged loads swung between poles, as in later days the ponies did with the lorge poles. There were no horses there then.

Later on in 1716 another Spanish expedition swung east across the plains from near Santa Fe, X. M., going clear to the Missouri. They took numbers of horses with them and their reports of the trip tell of the wonder of the Indians at the animals, showing that they knew nothing of them at that time. However, as the Spaniards had with them both mares and stallions and were constantly losing them from various causes there is little reason to doubt that the original stock from which the great herds of will horses (mustangs) came, was brought by these Spanish expeditions. The few that were lost bred rapidly under unusually good conditions and in a comparatively few years they could be found everywhere on the plains.

Stockmen's Horses.-The stockmen brought many horses with them which they turned out on the ranges 
to graze with the cattle. So long as the ranges were good and not orerstocked these horses bred and did well, but with depleted ranges they rapidly deteriorated until the raising of range horses was almost abandoned. From 1890 to 1900 horses were a drug on the market and were shot and killed as nuisances on the ranges. With a reduction in numbers and the great demand due to the Boer Mrar and later on the Russian-Japanese $1 \mathrm{~T}$ ar, they were gathered up and shipped out by thousands until the ranges were almost cleaned up.

Then came a reaction, and men saw that horses could be raised on the ranges with success, if they were given proper attention and fed in winter when feed was scarce. loday, while there are fewer horses on the western ranges they are worth more per head and get better care than formerly. The western stockman is gradually working back into the range-horse business with great success.

Mustangs.--There has been a great deal of romantic nonsense indulged in over the mustang. Ifis beautiful build, wonderful endurance and remarkable intelligence have been written up in glowing colors. Most writers have assumed that mustangs possessed these attributes because they were descended from the horses brought over from Spain by the early Spanish explorers, and they did of course doubtless have their beginning in this manner. The facts are that the true mustang was a smallboned inbred undersized pony, generally of an "off" color, mean of temper and narrow between the eyes. Nor is there anything in existence to prove that because he came over with those conquistadores he was of royal Arabian descent. The Spanish people as a race have never been noted for possessing or raising horses of 
very good blood, and there is nothing to show that the animals Corte\%. Coronado and the rest of the carly explorers brought wer with them were anything but the small common-bred horses such as the Spanish then generally used.

"Mustanging" was like trout fishing. It is always the big ones that get away. When you did get a bunch of them into a corral you found they did not look half so large and handsome as when they were first sighted on the prairie. The "coal-black stallion with arching neck, and tail and mane dragging the ground," which led the band, was the "lilying Dutchman" of the plains. True, there was in later days an occasional large, wellbuilt, well-bred horse seen among the mustangs, but when captured it always turned out to be an "escape" lost from some stockman's herd or traveler's team, generally well-branded and saddle and harness-marked. The wild horses of the present lay are not mustangs at all but merely well-bred horses that have been allowed to get away from their owners through poor range handling or lost from pastures or wagon trains. In some respects these later wild horses are far harder to capture than the old mustangs, because of their greater intelligence and speed.

Wrong Use of Names.-In speaking of the different types or breeds of horses and cattle, there are several words that are constantly misused. It is not correct to speak of a Thoroughbred cow. Cattle can only be purebred, grades or scrubs. One should not call a running horse standard-bred. The running strain of horses are Thoroughbreds only, if they have the requisite breeding. This is the name applied to the English running breed. All American trotting horses that come up to 
certain requirements of blood and breeding are standard-bred. Percherons, Clydesdales, Shires and other heavy horses are draft horses or drafters.

Sheep Introduced.-The first sheep within the area now embraced by the United States were brought into what is now the state of New Mexico by the Franciscan friars, who accompanied the Spanish conquistadores on their journeys into that region from Mexico in search

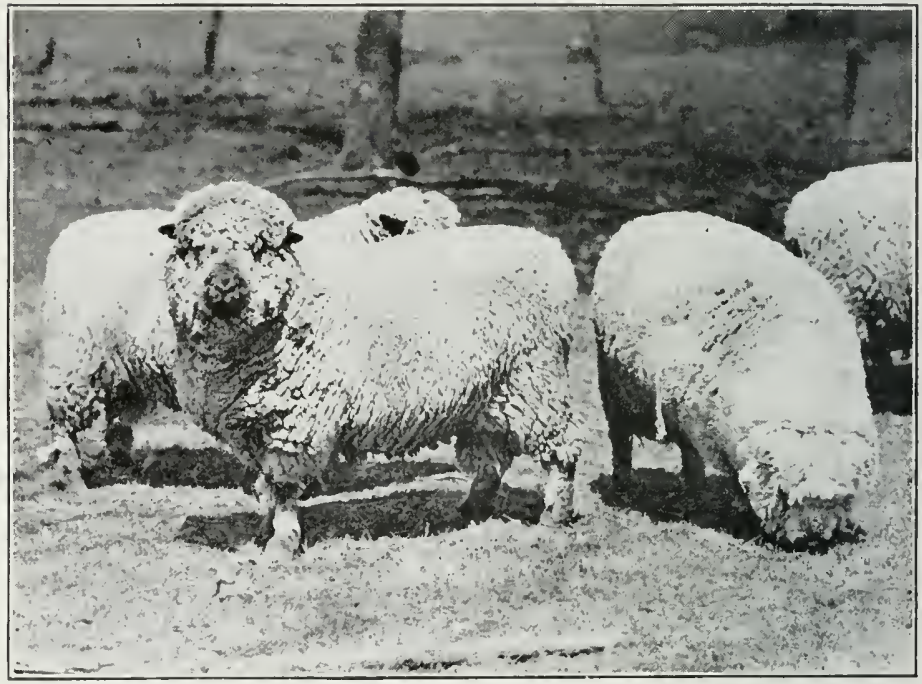

A Pen of Shropshires.

of the fabled "cities of Cibola." It is recorded that in 1581 an expedition of which the friar Padre Luiz was a member brought a few sheep with them from Mexico and left them with the Indians at the Pueblo of Zuni, which lies today not far from the town of Gallup, N. M. The Indians in that region, especially the Pueblos, took kindly to the sheep business. 


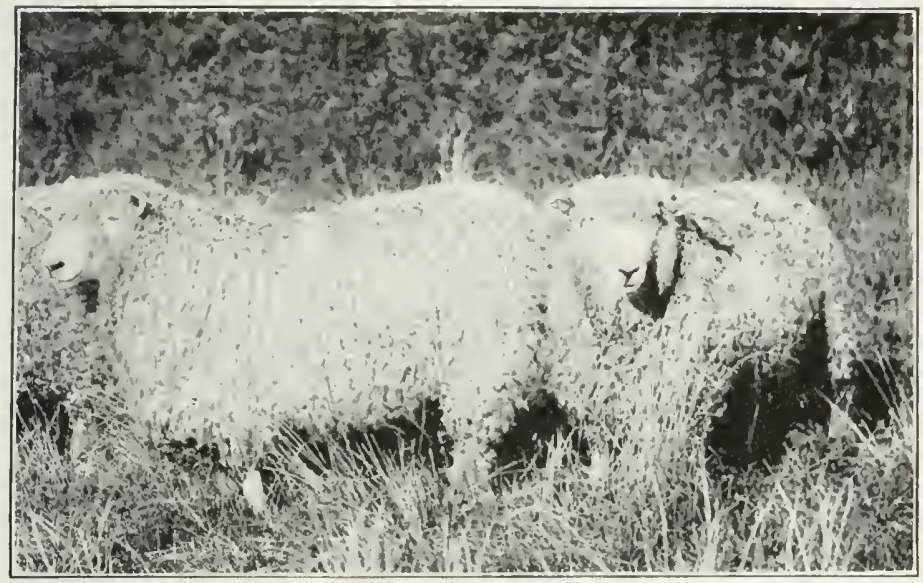

A Pair of Lincolns.

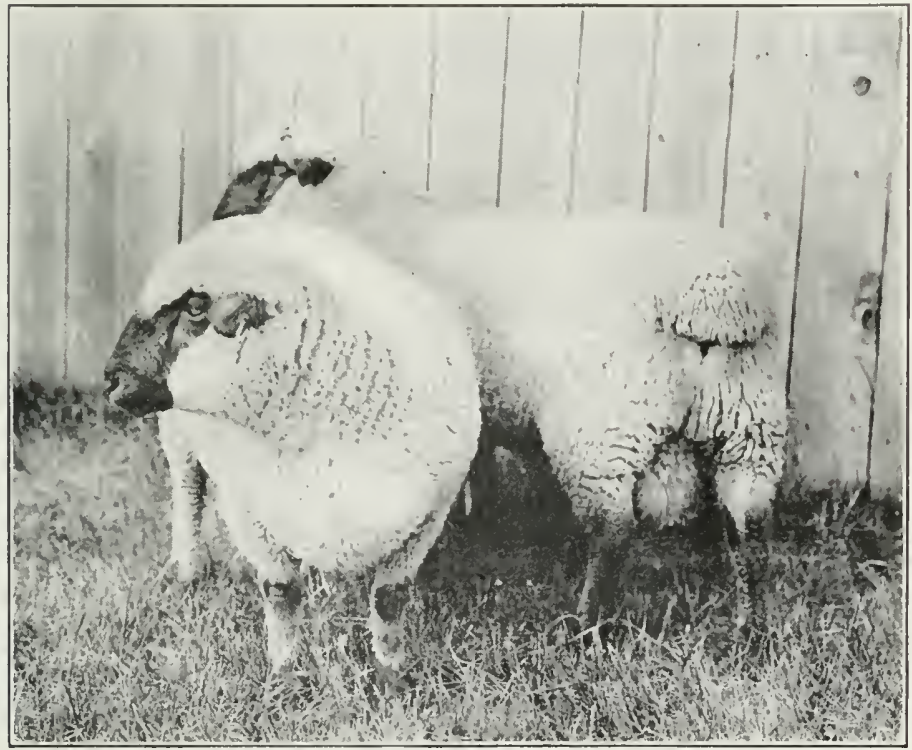

Hampshire Sheep. 
The I'ueblos with their permanent homes, domestic instincts and industry were peculiarly well fitted for shepherds, and in a comparatively short time the raising of sheep had become a regular business with them. Not only did they raise the wool but under the tutelage of the Spanish priests became expert blanket-weavers. Planket-wearing is always associated with the Navajo

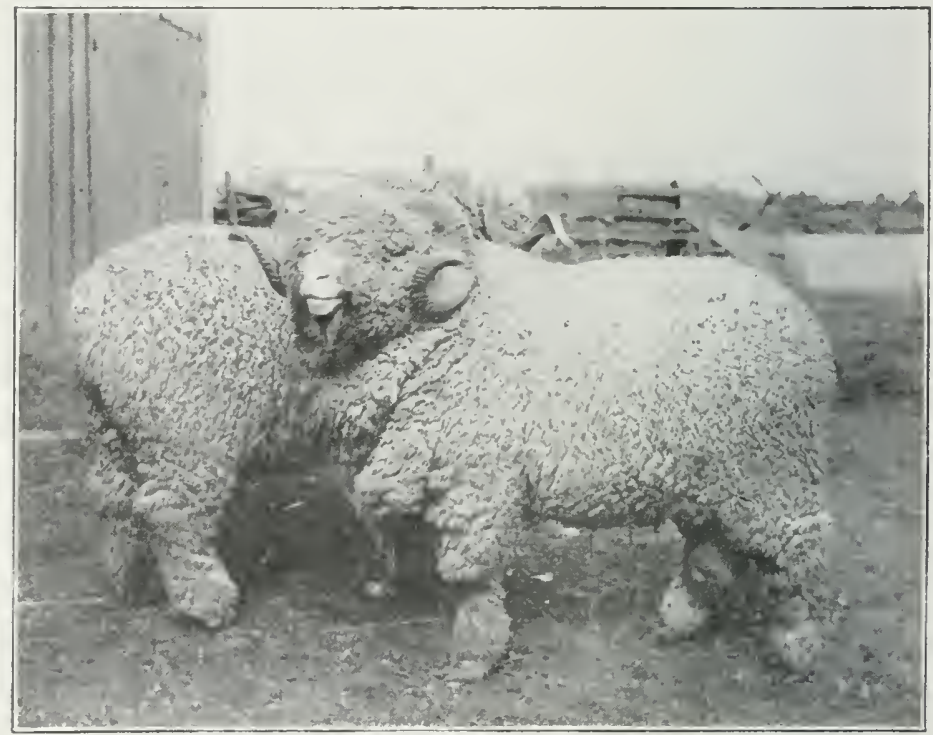

Rambouillet Rams.

Indian tribe of the Southwest, but the facts are, however, that the rarious Pueblos, notably the Zunis, Mokis, Acomas. Lagunas and the more northern Pueblo of Taos, were weaving blankets and raising sheep fully a century before the Narajos tried their hands at it.

The Navajos knew about sheep for many years, owing to their predatory habits of raiding the herds of the 
Pueblos and Spaniards alike. Due to their unsettled mode of living, they did litte towards raising sheep until they were placed $11 p$ on a reservation in southern New Mexico near fort sumner in the early $60^{\circ}$ s. There they were forced to take up more civilized industries, and when they were later removed to their present reservation in northern Arizonit and New Mexico they had progressed so far in the arts of peace that the Covernment aisled them by supplying the tribe with 30.000 sheep and 2.000 guats. It was the hope of the Government officials that through stuch means they would forsake their warlike methods and become peaceable, and the results have more than justified the trial. No nation with a million sheep scattered ont over the deserts and mountains can afford to risk its property by making war upon its neighbors. Hence the Narajos ceased their raicls.

Early Shepherding. - The conclitions surrounding sheep-raising in New Mexico up, to within a few years were almost ideal in their character and much like those of ancient biblical times. The whole people were interested in the industry, and it was the sole means of support for a large majority of them. Some of the heads of the older families were veritable patriarchs in their loldings, and the lancls and herds descended from father to son for many years. Some of the older Spanish-Mexican families have grazed their sheep continuously on the same lands for more than 200 years. and are today occupying the same ranges upon which their forefathers settled.

The New Mexican sheep-grower was not so advanced, however, in his ideas as to improving his flocks as American flockmasters, and for this reason until recent years 
the standard of New Mexico sheep has not been very high. They have been light shearers, bare-bellied and small-bodied, but extremely hardy and excellent feeders when placed under feedlot conditions.

California, with its great mountain ranges for summer grazing and vast desert ranges for wintering and early lambing grounds, offered an ideal place for sheep-raising. It did not take the early Spanish settlers long to realize this fact, and they built up their flock with the very best strains of Spanish blood, principally Merinos. As the country settled up the more enterprising California sheepmen pushed out into the deserts and country to the east, crossing the big Colorado River into Arizona. Here they found a virgin area sinilar in character to the coast ranges. Drifting across the desert that lies along the western border of Arizona, they worked their way into the San Francisco mountain country, where they established themselves permanently.

Impress of the Merino.--To this day the impress of the Merino sheep, which the early settlers like the Daggs Bros., the Clarks, Scotts, Camphells and other coast sheepmen brought into Arizona, can be seen in the herds of northern Arizona and especially about the San Francisco mountain region. Their good weights, splendid shearing qualities and hardiness make the sheep of northern Arizona superior to the sheep raised in any other portion of the Southwest. In the Northwest the California sheepmen also left their imprint upon the herds. A large portion of the original stock of sheep in Oregon, Wrashington, Idaho and Montana was brought from the Golden State, and through careful crossing the sheep of this region have become largebodied and heary shearers. 
All over the 11 est the original stock of slueep came from the Merino foundation, but there is a great variety of opinion among sheepmen as to the relative value of the varions breeds. Next to the Merino probibly comes the Shropshire, which is a sreat favorite with flock-

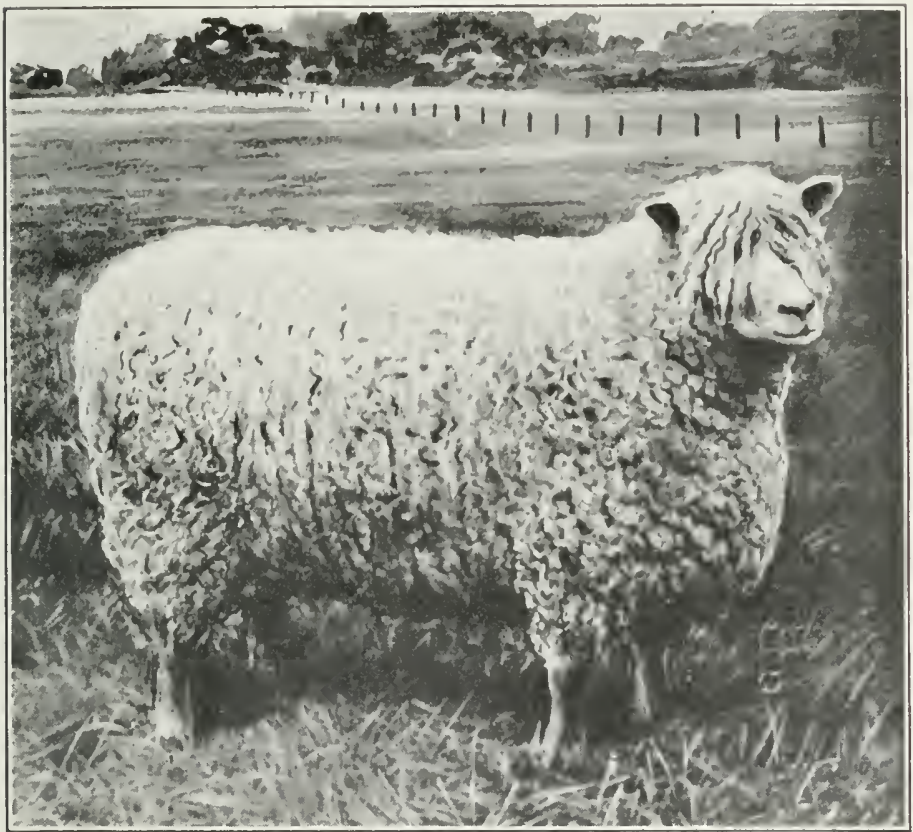

A Cotswold Ram.

masters in the West. The Lincoln, Cotswold, Rambonillet, Hampshire and other standard breeds of the heary mutton sheep, each with a strung following adrocating its superiority, are found doing well all over the western range conntry.

The western range sheepman has learned by experi- 
ence that the ewes he breeds from must have a certain percentage of Merino blood in them to give strong constitutions and the power to exist under the many trying conditions of climate and natural surroundings which beset range sheep. The Merino, together with Delaines and Rambouillets, which are but highly bred types of Merinos, is a breed peculiarly well constituted to meet such climatic conditions as are found on our western desert ranges. To such qualities they add the herding instinct, which is almost unknown in any of the various types or breeds of mutton sheep.

Securing Mutton Type.--Shropshires, Cotswolds, Hampshires. Lincolns and the other breeds of coarsewooled or mutton races do not herd well in large bands. They scatter out too much and if alarmed, instead of "bunching up" as will Merinos, often run in every direction. Of recent years, however, range sheepmen have turned their attention more to the mutton end of their business than formerly. Americans are learning to eat mutton more and more every year, and the long-headed men in the sheep business saw where they could have two strings to their bow by looking after the mutton business as well as raising wool.

Where this has been clone rams of the various mutton breeds are used to produce the class of lambs desired for feeding purposes. Then, in order to retain the vitality of the ewe band, part of the ewes are bred to Merino rams, retaining the resulting ewe lambs to take the place of the old ewes. For these reasons it is evident that a Merino foundation will always be desirable in the breeding of a band of sheep intended for range purposes in the West.

Goats.-During the past ten years the raising of goats 
of a higher grade than the ordinary animal of the humorist has developed into a good-sized industry. In New Mexico common Mexican goats hare always been raised in numbers, both for nilking prurposes and for skins. They thrive where no other chmestic animal but the

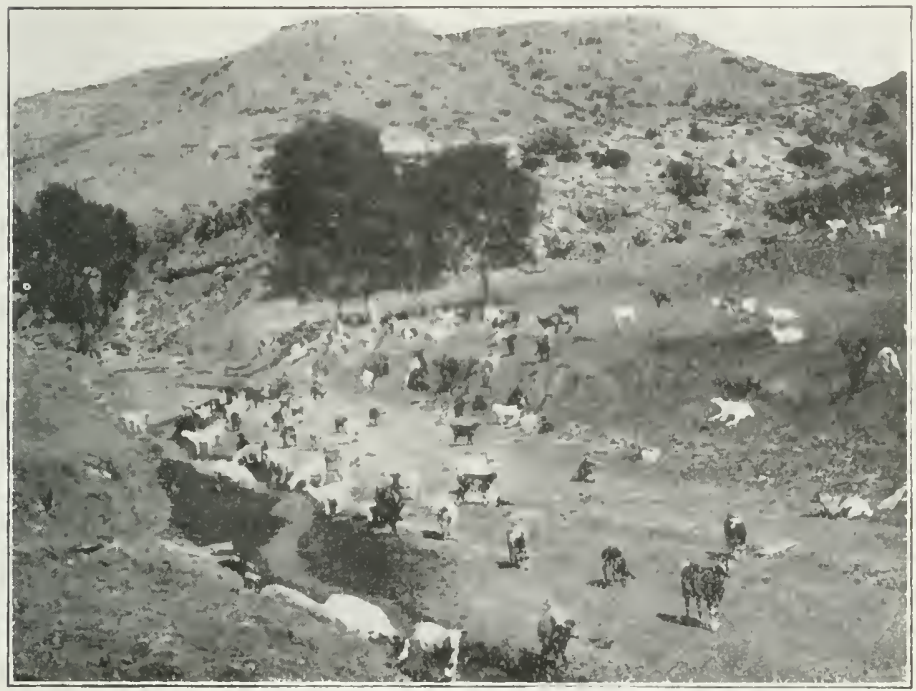

A Band of Common New Mexico Goats.

burro could fund a living, and need but little herding or attention from their owners.

Several years ago the proprietor of a large tannery where skins for ladies' shoes were an especial line began the raising of ordinary Mexican goats in northern New Mexico on quite a large scale, sulely for the hides. It was soon discovered that where they could be raised in small herds with rery little care, when placed in large bunches and handled on a business basis they lost money for their owners. So the big goat ranch was abandoned, 
the owner gave up the idea of raising his own goat skins in large quantities and went back to the old method of obtaining his supplies for tamning purposes.

Angoras.-For many years the raising of a higher class of goat, the Angora, has been carried on in the United States, particularly in the Southwest and on the Pacific Coast, where there are sereral herds of imported

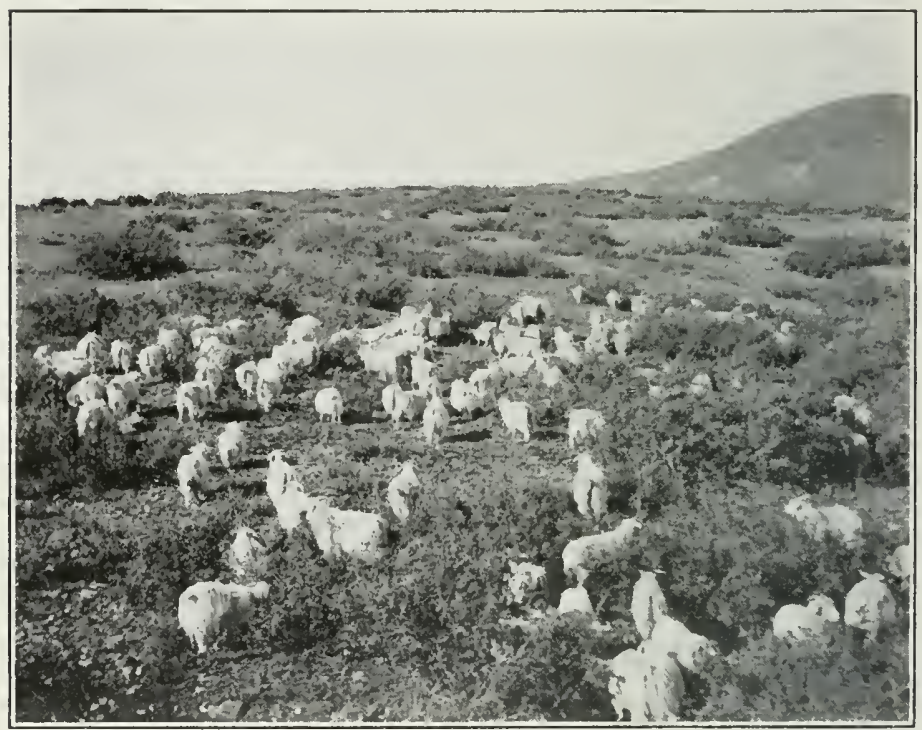

Angoras on Brushy Hillsides in Arizona.

goats from the best blood in South Africa and Asia. The value of these animals is two-fold, like that of sheep, in that they furnish a material for manufacturing purposes in their hair, and atso yield food.

Goats can be raised on lands that furnish but little feed for any other domestic animal. Brushy hillsides are their abiding places and the more rugged and rocky the 
range the better they like it. In the Southwest, especially in New Mexico, the industry found a splendid opportunity to develop, and areas of many thousands of acres covered with the densest thickets of underbrush furnished the best range for them. The region about Silver City, N. M., is in the heart of a goat-raising district, and nearby will be found some of the largest and bestbred herds of Angoras in the WVest.

There are also a great many Angora goats in west Texas, Arizona and California, and the introduction of improved billies from Africa, where the best blood from Asia was originally taken, has brought the standard of the herds to a very high degree. Experts believe that the Southwest offers almost ideal conditions under which to raise a class of Mohair equal to the very best imported. In 1881 the Sultan of Turkey absolutely prohibited the exportation of any more Angoras from that country, and although a few head have since been smuggled out the South African supply has been the main source of the importations into the United States, until recently, when the South African government prohibited further exportation from that country also. Fortunately, however, the importations into the United States had been of so superior a class that it is believed American Angoraraisers can keep up the standard of their flocks without further infusion of foreign blood. Many expert authorities believe that, due to the great care in selection, the skill in breeding and the business-like manner in which American Angora-raisers have handled their flocks the breed here will eventually be superior to that of either Turkey or South Africa.

This is undoubtedly true so far as Turkey is concerned, because the breeding of Angoras there is not in the hands 
of people who are capable of giving it the care and attention it should have. In fact, the breeding of Turkish Angoras has been seriously lowered in recent years through the carelessness and lack of good judgment by breeders who recklessly crossed their best blood with the common Kurdish goats in an attempt to improve the character of the mohair. The result of this has been an increase in kemp which has seriously injured the value of the mohair. Kemp is the coarse chalky-white hair which is found in even the best of fleeces, and which many breeders believe can never be wholly bred out of Angoras. It is a reminder of the common goat from which the Angora was originally bred. Some American breeders believe that with careful selection kemp can finally be entirely eliminated. The objection to kemp, apart from its coarseness, is that it will not take the various dyes used, and thus it greatly injures the quality of the manufactured product.

The best grade of mohair should hang in long curly ringlets from all parts of the animal's body and possess a beautiful silky sheen. To be of value it should not be less than six inches in length, of uniform size from root to tip and free from stain. The price per pound rises rapidly with the length. As much as $\$ 14$ per pound has been paid for twenty-two-inch lengths, while there is a steady demand for good fleeces between ten and fifteen inches long at prices ranging from $\$ 6$ to $\$ 10$ per pound. The sum of $\$ 115$ has been paid for the fleece weighing eighteen pounds from a single Angora raised in Texas, and buyers will take all they can get at such high figures, if it comes up to the desired standard of length. 
The average yearly shearing of a bunch of range $\mathrm{An}$ gora goats is probably about $21 / 2$ pounds, although of course small lots of well-bred goats will average higher. However, it is doubtful whether taking the shearing of a large number of herds in the range districts they will average much more than this limit.

The success of the industry is partially connected with the demands of trade. A change in the use of certain lines of plushes and that class of mohair goods. due to caprices of fashion, has caused a fluctuation in the value of the hair from $\$ 1$ to one-fourth that sum.

The goats are much in demand by farmers who desire to clear up brushy areas upon their farms, and thousands of them are annually shipped from the southwestern regions to the eastern states to be used as brush destroyers. As meat-producing animals their position is not at present fully assured. Growers call the meat Angora mutton or Angora venison, and the flavor and delicacy of the meat, especially of the kids, is unequalled. The prejudice against goat meat. especially among people in the West, is hard to overcome. and there is no just reason for it, but when it comes to questions of taste in eating, reason seldom enters into the matter. The prejudice is there and argument or discussion seldom removes it. The time will no doubt come, however, when with the increasing high prices obtained for mutton and beef, Angora venison will find its way into use as a substitute and have its place as an approximately new food supply.

Hogs on the Ranges.-That the hog is a range animal may seem absurd to some, but the truth is that in the West, and especially the Southwest, thousands of hogs are raised almost entirely on the open range. Of course 
the most successful raisers are those who graze their hogs on the open ranges while the crop of acorns and other feed is plentiful, taking them up and feeding them corn when the range feed is short. Still there are many hogs raised the year around on the range, just as are the cattle and sheep.

In many districts hogs are treated much the same as the cattle. They are ear-marked and branded by their owners, rounded up at stated times and taken home for killing or sale. I have seen hog roundups in the Tonto Basin country in Arizona where hundreds of the animals, wild as deer, and some of them fierce as tigers, were gathered together. The young were ear-marked and branded exactly like cattle. Those needed for killing were cut out and driven home, and the rest were turned out on the range to take care of themselves for another year.

In northern California, where the mountain lions and other predatory animals make heavy inroads on hogs, the owners place large cowbells upon the sows. A double strap is generally used, one about the neck and the other behind the fore legs and connected with a strap to the front one. A bunch of old sows lying peacefully in a hidden mudhole in the thick oaks and suddenly disturbed will make about as alarming a racket as can well be imagined-enough to frighten away any marauding animal with pork-eating proclivities.

The raising of hogs under these conditions is satisfactory, so long as they can range in a region not occupied by settlers and their farms. Where there are fields and gardens with irrigation ditches, hogs are a great source of trouble and must naturally be legislated against. This is also true in mining districts, where wa- 
ter for hydraulic and milling purposes is brought in open ditches which furnish the animals with a splendid place in which to wallow, much to the injury of the ditches and their contents. 


\section{HANDLING CATTLE ON THE RANGE.}

While the old-time conditions of the palmy years from 1885 to 1900 are gone, never to return, there are yet many large range cattle outfits left in the West. This is especially true of the southwestern section of the country, where, in Texas and New Mexico, can be found companies with cattle running into the thousands, which graze on the open range.

Number of Range Outfits.-Most of the Texas outfits have their herds in fenced pastures, but the enclosed areas are so large that it practically amounts to open range conditions in handling stock. The Matadors, X I T's, L F D's, and a number of other big concerns in Texas, own herds of from 30,000 to 60,000 head, ranging in great pastures of thousands of acres.

In the southeastern part of New Mexico there are several big outfits that graze on the open Government ranges lying east and west of the Pecos River. Some of these companies own as many as 40,000 range cattle. The great Bell Ranch in central New Mexico owns a Spanish grant of almost a million acres, all under fence, on which they graze 40,000 to 50,000 high-grade cattle. There are many large companies scattered through New Mexico, especially in Socorro and Grant counties in the southeastern section of the state, where one finds herds 
like the Diamond A's $(M)$, the $V$ Cross T's $(V+T)$, the Bar W (W) with from 10,000 to 40,000 head each on the open ranges. 'The Diamond A's have one fenced pasture near Engle, N. M., containing more than 700,000 acres.

Arizona was once the home of several huge range outfits, but the years from 1893 to 1899 saw many of them shipping out their stock and abandoning the business, especially in the northern part of the state, where the sheepmen gradually forced them off the ranges. The largest of these was the Aztec Cattle Co., which in 1888 was running 60,000 mixed cattle on its Little Colorado range, all in the famous West lexas Hash Knife brand $(-1$ ). In southem Arizona aljout Wilcox and near Tucson there are still several good-sized ranges like those of the Sierra Bonita Co., the San Simon, the Empire Co. and the holdings of the Greene Cattlc Co., each of which probably runs up into herds of more than four figures.

There are several very large companies operating on the open country in the eastern and southeastern part of Colorado, the Prairie Cattle Co. of La Junta probably being the largest of them all. These Colorado outfits, however, are generally steer ranches, and either own stock cattle in the southern country from which they draw their steers or buy them and ship up from below. In the Northwest there are comparatively few outfits handling stock cattle at the present time to any extent exclusively on the open range. Some of the largest of them are in Nevada, Utah and Wyoming. There are, however, many good-sized outfits all over that region and in South Dakota and Montana, that handle steers in large numbers, but with the rapid encroachments on the old ranges they are fast disappearing. 
But in the Southwest, owing to climatic conditions, it will be some years yet before the dry farmers or any other class of settlers can make such inroads upon their ranges as to force them entirely out of business. The settlers have already cut into the ranges in this section to a very serious extent. It is believed, however, that the limit of their advancement has been reached and that the wave of settlers that has been sweeping across this region in the last few years, beginning about 1902, has reached very close to high-water mark. Under all present known conditions of farming, little further extension of the possible area under which dry farming may be carried on successfully can be expected.

Past and Present Range Conditions.-Upon the southwestern ranges the old-time conditions are still found with modern improvements. The advent of the barbed wire fence probably did more to improve the condition of the open range stockman than any one thing that has come to him. The former harum-scarum methods are gone. The breeding of the cattle is greatly improved, and they are better handled, better looked aiter and the whole business is upon a more business-like basis than it was years ago.

One can still find the old-time "chuck wagon" and the great mess box with its hospitable lid and cranky cook. The horse wrangler still occupies the next place in importance in the outfit, and the bronco buster plies his vocation as of old. There is lacking, however, the old free wild and woolly time. No more does the bad man of the outfit shoot holes in the camp kettles or coffee pots because the quality of the grub does not suit him.

The broad-brimmed Stetson or Mexican sombrero has gone, and in its place one finds them wearing small 


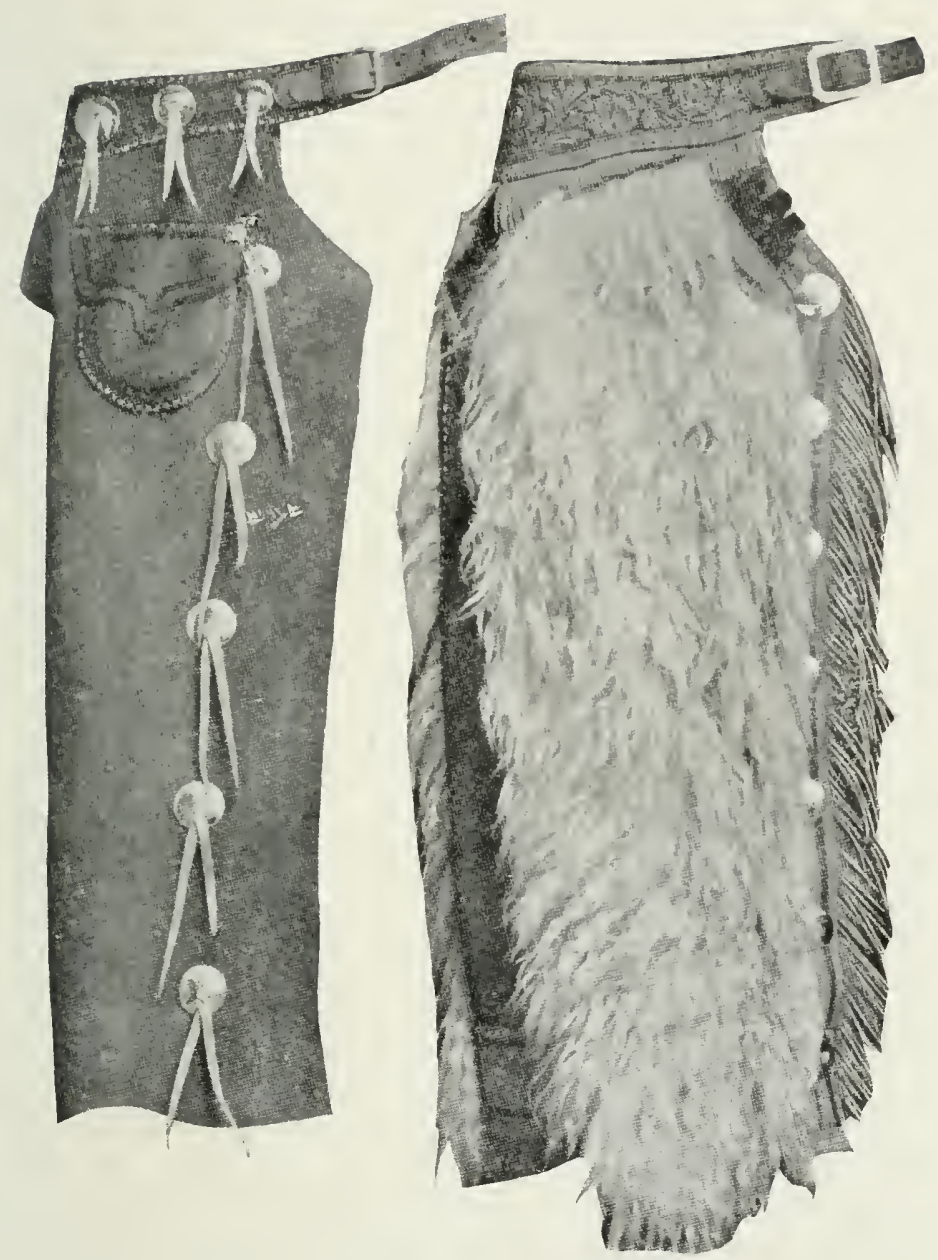

The Chaparejos With the Goat Skin Front Are More Theatrical than Practical. 
brimmed black hats or even Fedoras, which will turn down over their eyes on a sunny day and do not weigh so much as the great broad-brimmed hats. They stay on the head better, too. The long hat strings, which every man once spent hours to plait from strings cut from the tops of his old boots, and whose long tails ornamented with fancy turk's heads and other knots hung down his back, are also gone.

The high-heeled boots are not so prominent. Once no self-respecting puncher considered himself dressed for work until he had his feet inside of a pair of $\$ 15$ boots made by one of the farorite boot-makers, whose merits they discussed about the camp fires night after night. Great high tops they had with stars in red and blue. and fancy sewing all over them. At the bottom of the three-inch heel the real "top waddy" had a silver quarter fastened as a plate.

Then the "chaps" are also gone. Probably the average easterner will see more men wearing chaps in a year if he attends the Buffalo Bill and other tent shows and keeps track of the various theatrical offerings that furnish pictures of western ranch life than he would if he spent five years on the western ranges. Here and there one will find a man wearing chaps on the range. but they now are generally conspicuous by their absence.

Old-time Equipment.-But in the old times-Ah. what money was spent on such things! Silver-mounted spurs. Spanish "spade bits" that cost from $\$ 15$ to $\$ 30$. headstalls that took hours upon hours to plait, reins that were twenty-four-strand and plaited from the finest grade of whang leather ornamented with wonderful knots, fancy buttons and tassels. Then there were 
cight-strand reatas whose making took days of careful work and used up the center of half a dozen of the finest calf skins; quirts, the result of hours about the camp fires (they were works of art); lair ropes ("mecates") spun from the very choicest mane luair taken from some bunch of "broom tatils" (mares) which the boys rounded up on an afternomen and spent hours in throwing in order to obtain the hair.

Let there come an odd afternoon when the outfit is not working and out frum some one's bed roll comes a set of hair spinners; from the botton of the "chuck wagon" a gunny sack of hair is dug up, and soon they are busy making hair ropes. One man picks the hair while two others spin the strands. By selecting the colors of the hair, red, white or black, it is possible to secure very handsome ropes of natural colors. When the rope is finished it is washed in a bucket of water in which is placed a handful of soda stolen from the cook's can. This bleaches the white hair and when the ends of the loose hairs have been singed off and a turk's head worked in one end the rope is finished.

Contrary to general opinion, the hair rope is valuable meither for its great strength nor roping qualities. As a catch rope it is a failure because it is too light to throw well and offers too much surface to the wind. The rope is not particularly strong and will not stand any severe strain. Its chief value is for reins for hackannores in handling young horses and for tie ropes for saddle horses. There is a certain amount of spring or give in hair ropes, and they do not slip through the hands so readily as hard twisted ropes.

One reads occasionally of old hair ropes made from the hair of young women captured by Indians, which 
have been used to rope buffaloes and wild horses. I do not say that they were never made of such materials or used for this purpose, but I have serious doubts about the matter.

The "Bog Rider."-In some parts of the West, especially in the Southwest. where owing to the quicksand the streams are very dangerous, the stockmen are compelled to fence up long stretches of the more treacherous spots. This forces cattle to water at points where through rocky ledges coming to the surface or other natural reasons the bottom is more reliable and the animals do not bog.

When cattle have been without water for long periods they reach the streams famished, and in their eagerness work far out into the stream, meantime slowly sinking into the quicksand. Then when the animal, not any too strong, and burdened with several gallons of water, tries to lift its feet they are fast in the grip of the sand and slowly but surely settling deeper and deeper into it. In ordinary circumstances, if the feet are buried in the sand not more than six inches deep, the animal is unable to release them. The suction that seems to exist under such conditions holds the foot as if in a vise. It was common to see a cow"s leg broken where the "bog riders" (men employed specially to ride the banks of these streams at certain seasons) found the animal with but one font fast in the sand and tried to pull her out with their ropes, without first digging the foot free clear to the very toes. On a good square pull it was impossible for a strong horse to pull a cow out of such a position where two feet were fast in the sand up to the knees until they had been dug clear out. With but one foot fast and buried not much over the hoof, a strong man with a rope fastened about the animal's leg is often unable to lift the 


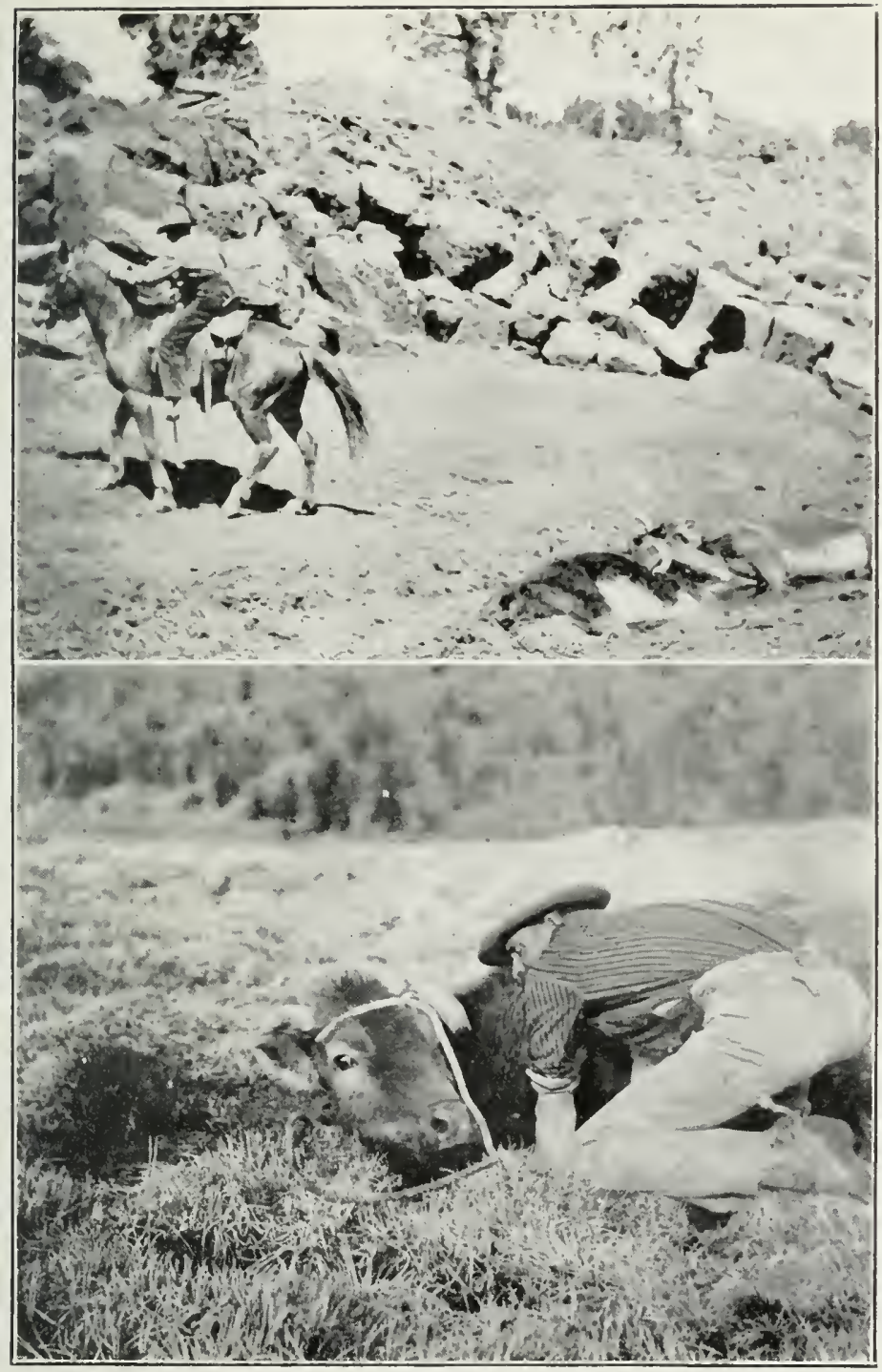

"The "Bog Rider" at Work.-Top: Pulling a Cow Out of a Bog Hole (Rope Attached to Saddle Horn), Bottom: Trying to Save a Cow. 
foot out of the sand until it has been dug away with the hands or a shorel and thoroughly loosened.

Generally in the Southwest the cattle began to "bog down" in Narch, and bog-riding was necessary until the cows began to gain strength, which was in May. During these two months the losses were severe because even if the animal were pulled out by the riders, if she had been in the icy cold water for more than a few hours she was so chilled that she had lost all control of her limbs, and frequently could not get 11 at all.

During the spring of 1893 by actual count more than 1,000 cows were pulled out of the Little Colorado River in Arizona in a stretch of fifty miles. Every one died where the "bog riders" left her-on the bank of that treacherous stream. Besides the dead, about as many more were pulled but managed to get up and stagger off onto the range, where we used to estimate that not more than one in every five lixed to raise her calf.

The work of the "bog riders" was very hard and disagreeable. The men generally worked in pairs, and while one pulled at the animal by his rope at the horn of his saddle the other waded into the cold water, dug the animal's feet loose and lifted and boosted on her until between them she was worked to the bank. There she was "tailed up" and got onto her feet, if that was possible, or left to die. Bog-riding was not profitable to the cowmen but it seemed dreadful to let them die in the water without at least trying to do something for them. If the cow did not get up within the next day or two the "bog riders" generally put her out of her misery, and skinned her.

The Indians coveted the hides for moccasin soles and after a good many bogged cattle had been shot by them and skinned it was deemed advisable to make an example 
of them. So one or two were caught and tried and punished by jail sentences for killing live strok mulawfully. After that we began to find cows in the bug with the hides peeled from their backs kown to the water or mudline, and still alive. I well recall our horror when we ran across two cows lying in an out-of-the-way bog hole, each skinned down to the middle of the sides but still alive, as was shown by their moving eyes and the gritting of the teeth which suffering cattle frequently do. We finally managed to eatch two Indians red-handed who when brought into court acknowledged their offense but declared they had not killed the cows, but as they were sure to die anyhow thought they might as well gret the hide as to see it wasted. Ne got them on the cruelty to animals law.

"Developing" Water.-Igain in the early days during the dry seasons such streams as the Arkansas in Colorado, the Little Colorado in Arizona and the Rio Grande or Pecos in New Mexico were mere sandy wastes for miles and miles, showing no water whatever on the surface. The experienced cowman, howerer, reaching such a stream first drove the saddle horses across the sand several times to "settle it." This would pack the quicksand and as the horses were strong and active and kept on the move, none of then was caught in the sand.

After the sand settled. the cattle were driven onto it and with their milling about in search of a drink the settling process was completed and the sand became as hard as a city street. With this hardening process the water immediately began to rise above the sand and within half an hour there would be a good-sized stream flowing where there lad been 110 signs of water whatever. Twelve hours after this the water had again disappeared and the sand was almost as soft and treacherons as ever. 
Range Methods.- On the range the cattle are still handled in the same manner as of old, with modern improvements. The roundup outfit takes breakfast at 4 a. m., as of yore. Around the campfire the shivering boys gather to eat, and by the time that is over it is probably light enough to distinguish objects. Each man takes his night horse, which has been tied up near camp all night, and rides off into the prairies, looking up the saddle horses hoppled out the night before.

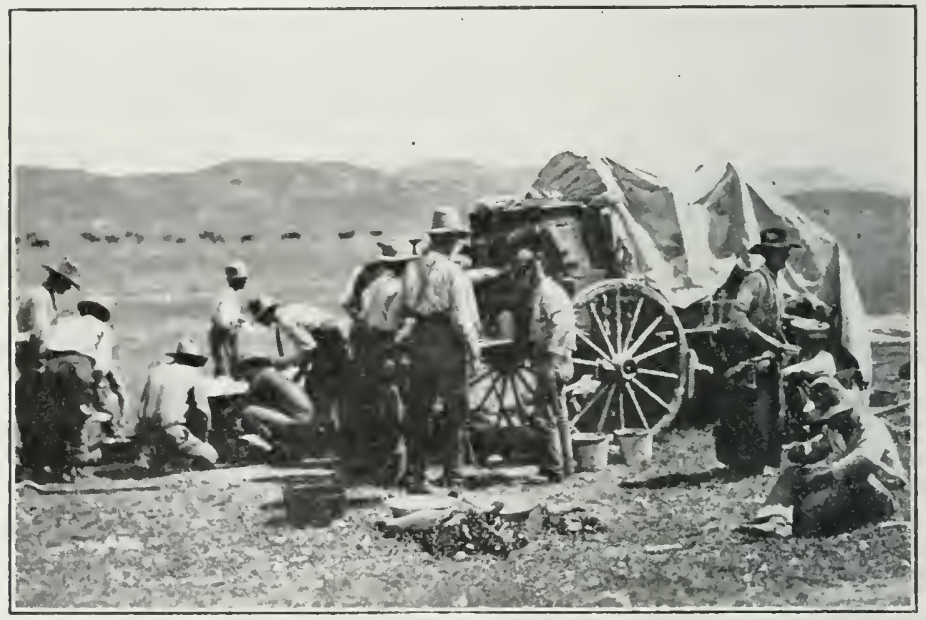

A New Mexico Round-up Outfit and an Old-time Chuck Wagon.

One does not walk up to the arerage cow pony that is hoppled ont and expect him to stand still. He is not broken that way. Instead, when you are about ten feet from him, stoop down as low as you can and crawl up to hin, not looking up at or noticing him in any way. He will let you touch his feet and mhopple him very easily. If you should want that particular horse to ride, do not unhopple him until you have a rope about his 
neck, for the instant he fecls the hopples loose from his legs, away he goes. liy rising slowly, and carefully stroking his legs as you rise, it is possible to slip a rope about his neck with which to hold hin1. Do not make any sudden movenuents; go slowly and carefully, if you would capture him.

If the outfit has a night herder for the horses he will have them in at camp by the time the men are through breakfast. but the might herder should be seldom used, as

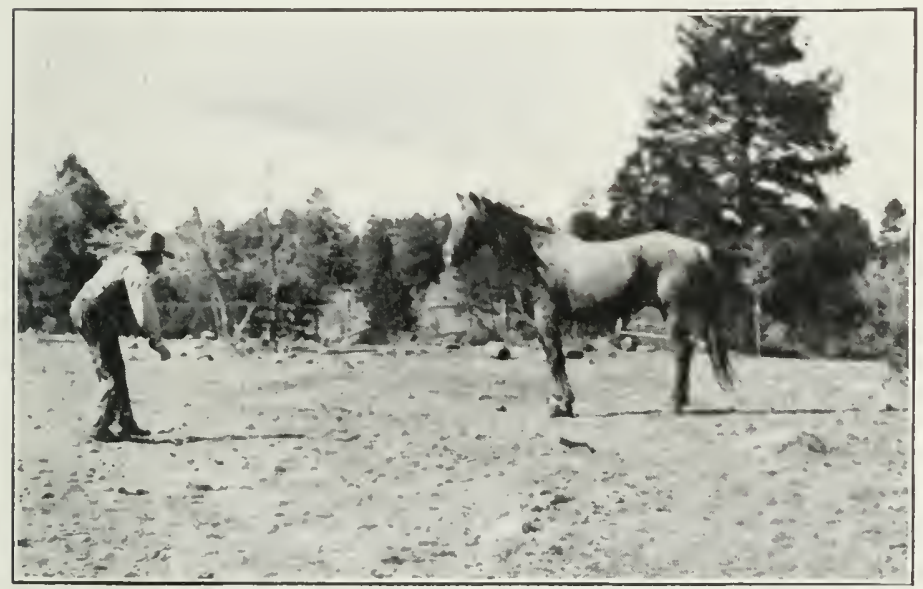

"Stoop as You Near the Average Cow Pony."

horses do much better loppled than herded at 11ight. Not one man out of a humberl can herd a lot of horses at night without bunching them so closely that they get very little feed. Ile is afraid of losing one, and so does not let them scatter out.

After the chuck wagon has been loaded and the cook told where to meet the outfit for dinner, the men ride back on the range. When the roundup boss has reached 
a distance from water where he believes the outside cattle are to be found he divides his party, dropping a man off here and one there. In this manner he spreads his force out fan-like over quite an area, and as they all have orders to drive to a certain point they work in harmony.

At first but few cattle will be found. Gradually they pick up more and more-here a few in this draw, there a little bunch in that canyon, and by the time they are half-way down the range they will have gathered a goodsized bunch. Gradually the men draw together. The trails converge at the watering place picked out for the roundup, and as the drives are laid out so as to follow as nearly as possible the daily drift of the cattle to and from water they are not hard to drive in. Gathered at the roundup ground, they are bunched up in one great herd.

Herds Not Large.-One reads of roundup herds with tens of thousands of cattle. This, like the hair rope story, is met with in books but in practice a herd of 1.000 head is all that can be successfully handled, and 500 is far better. I doubt very much whether any one ever sav 10.000 range cattle in one herd. In the first place the larger herds cannot be kept in shape. They are too bulky and unmanageable. Again. in such great herds the calves would become separated from their mothers and never be able to find them.

Sometimes large herds will be picked up at water. ing-places in dry times when the cattle are concentrated, but when this occurs the roundup boss, if he is a good man. will let the herd settle down for a time and then carefully cut it in two before trying to handle it.

Branding the Calves.-If the calves are being branded they are first cut out by the men. This is done quietly. 


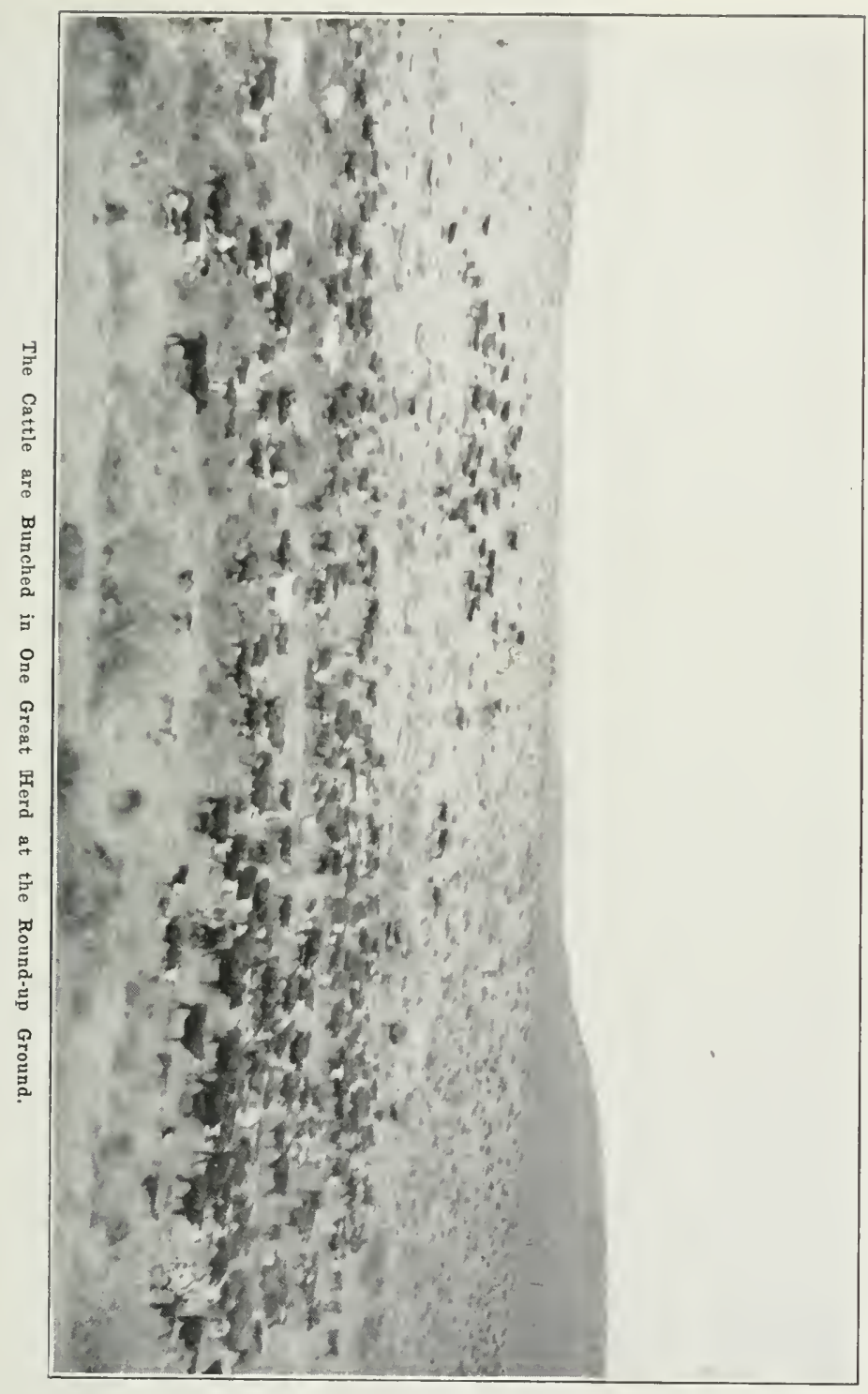




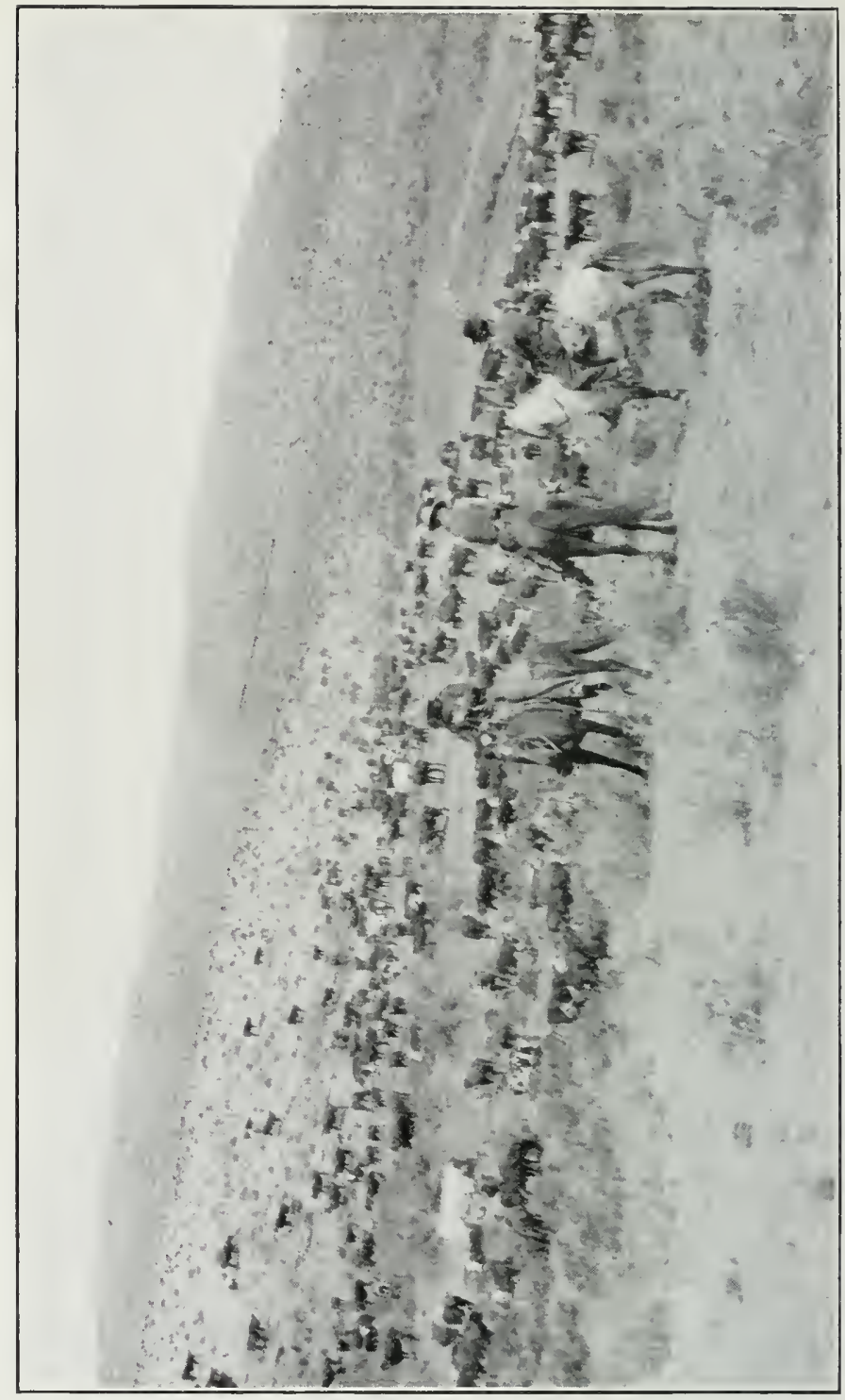

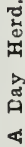


and easily so as to disturl the herel as little as possible. The men work singly, although in some places it is done by two men to a cow ("double barreled"), but this is not a good plan in a general way.

After the calves are out of the bunch the "dry stuff"steers, dry cows and strays-is taken out and thrown into the "day herd." The calves and cows are then tak-

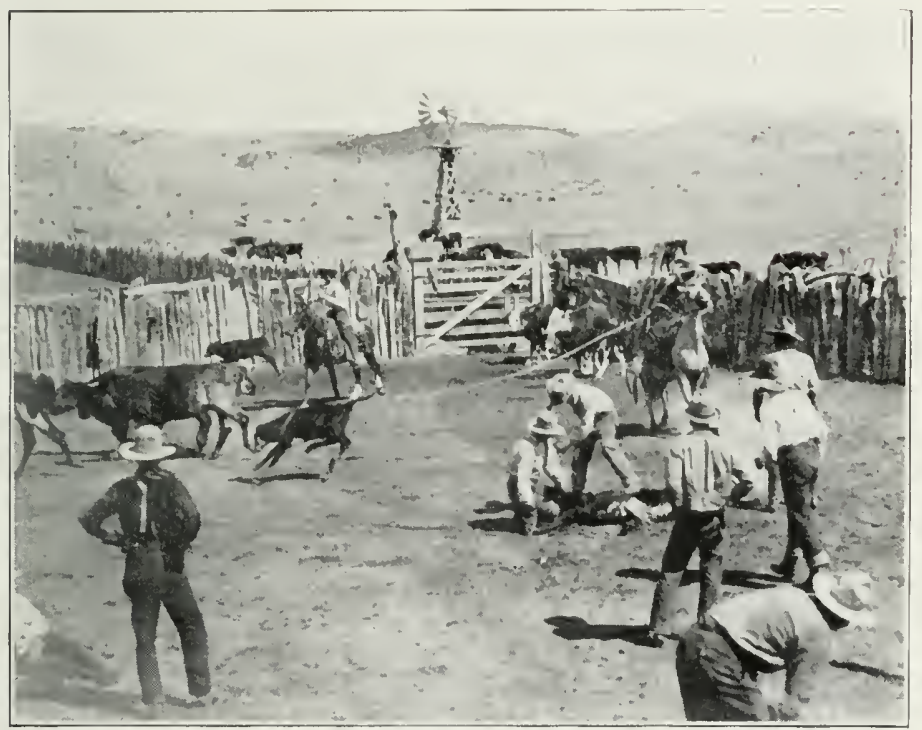

A Round-up Outfit Branding Calves.

en to some corral if one is avalable or rounded up on the prairie, a fire built, and when the irons are hot, the calves are roped and dragged to the fire. There two husky men grab them, one at the neck and the other at the feet, while others run up with sharp knives to mark the ears and hot irons to burn the brands into the sides or hips of the animals. 
A lively crew will turn out a good many calves per hour, all depending cu the speed of the ropers and the ease with which the animals can be handled. If there is a corral handy the work is easier, and when it can be done the calres are dodged out by dodge-gates and placed in one small corral, where the men work on foot. No ropes are used, a man grabbing a calf by the right hind leg while his partner grabs it by the tail. A quick

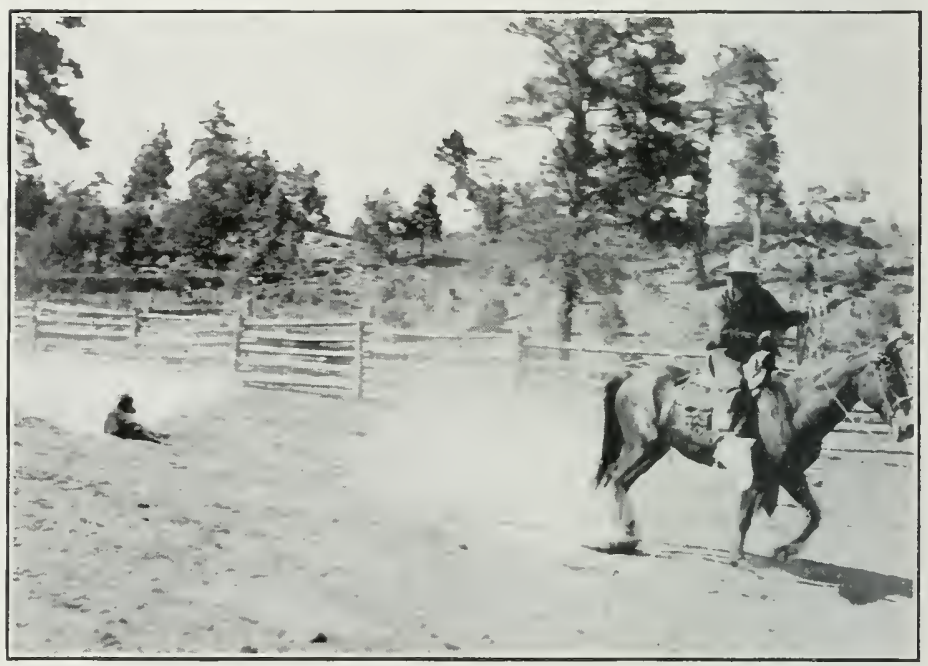

"They Are Roped and Dragged to the Fire."

jerk and the animal lands upon its side, and before it can rise it finds a man sitting on its neck and head with another at its hind legs, and the operation is soon over. Working this way, seven men will turn out seventy-five calves an hour, and as many as ninety an hour have been branded where everything went smoothly.

Some outfits that have corrals, particularly in Texas in the large pastures, use squeeze chutes for branding. 
The calves are generally not branded until they are eight months old and as they are pretty husky by that time the squeeze chute is a great sarer of hard labor. The chute for calves is the same as that used for large animals.

Night Guard Duty.-The day's work generally closes with the hoppling ont of the sadtle horses, and when

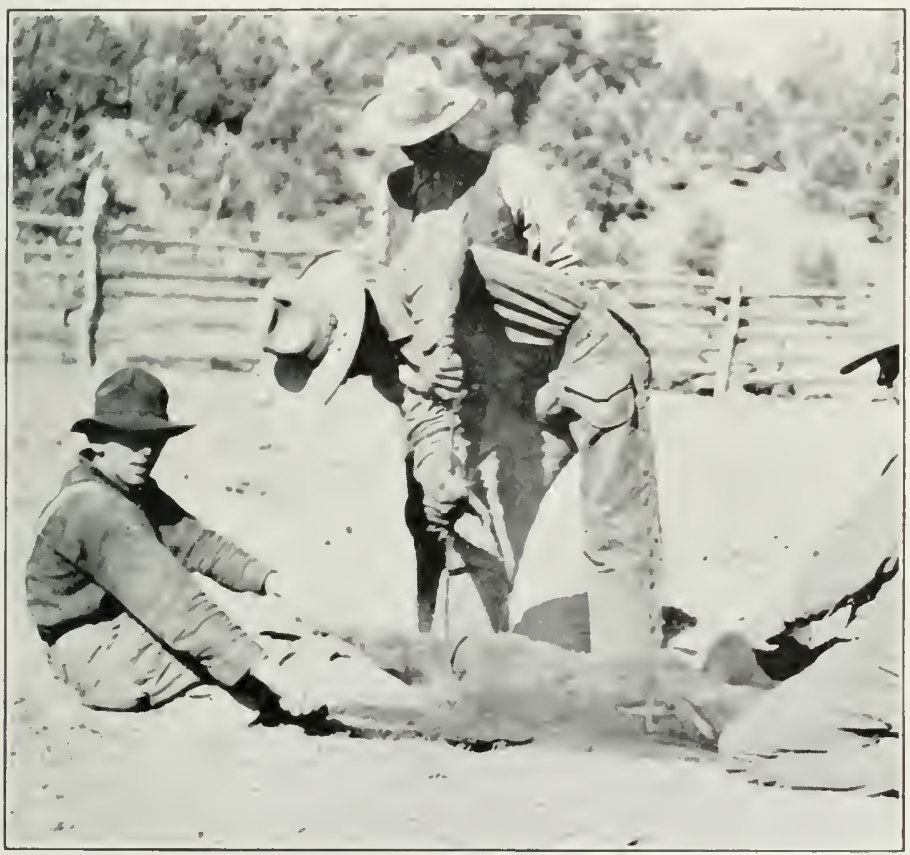

Putting a "Butt" Brand on a Calf (Note the "Slash Cross" Over the Ribs). the day herd is worked up close to camp and bedded down for the night the first guard take them in hand, and the rest of the camp goes to bed. Depending on the size of the herd, the guards are from one man at a 
time to three and cren four. The men ride in circles about the herd, so as to meet one another, and under ordinary conditions the animals make very little trouble. Occasionally some old cow, cut away from her yearling or separated from another cow which has been her "chum," will make a dash from the herd and try to escape.

Stampedes.-Sometimes at night when everything is quiet, a horse will shake itself, rattling the saddle

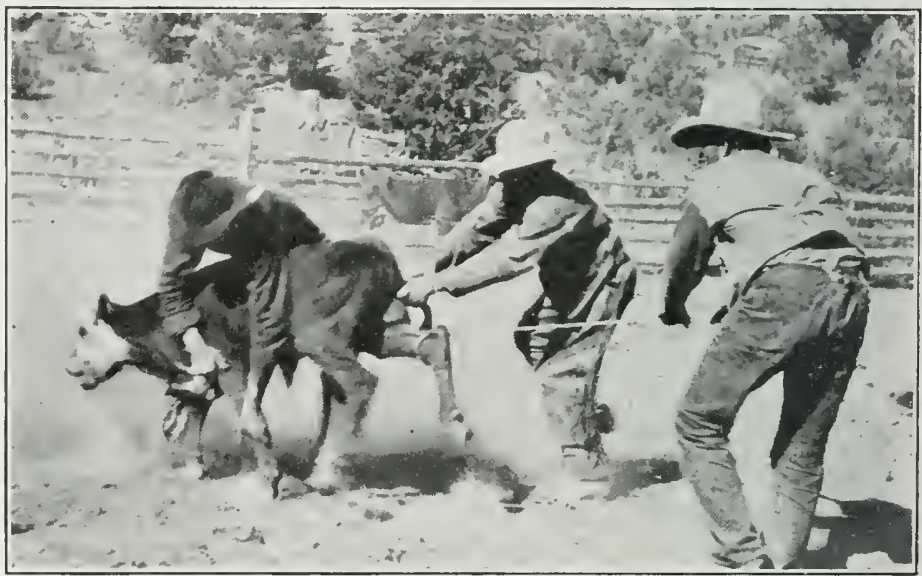

"A Quick Jerk and the Animal Lands Upon Its Side."

pockets; a guard will strike a match for his pipe, or a great horned owl will come swooping down over the herd. In an instant the whole buncl is on its feet and off, and the animals may run a thousand yards or a tenmile heat.

The men on guard do their best to point them around, so as to throw the leaders against the tail of the herd and thus get them to milling. If they are successful the cattle will run around in a circle ("mill") for awhile and 


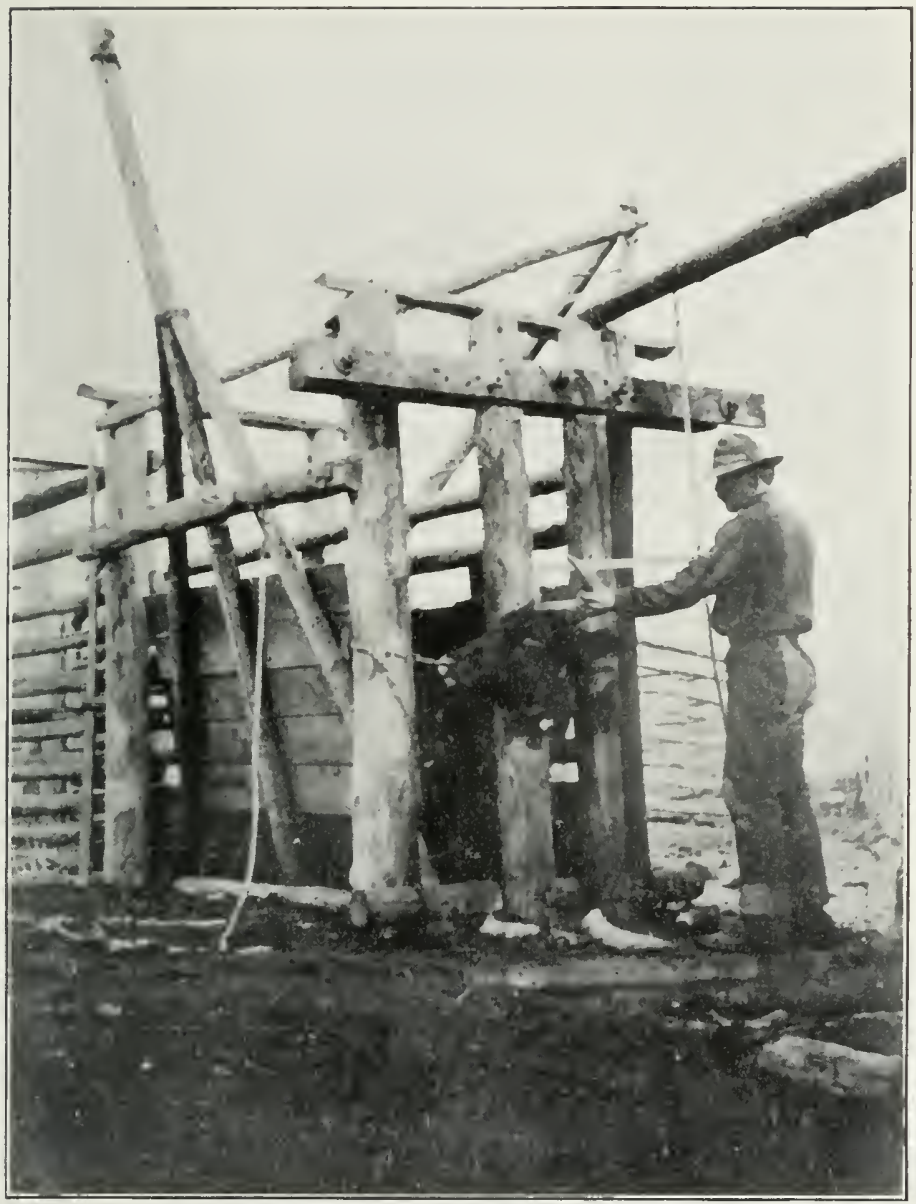

The "Squeeze Chute" for Branding and Dehorning.

then settle down and in a few minutes all will be asleep again. Sometimes on a dark night they will get miles away from the camp, while the men in camp sleep soundly and know nothing of the trials of the men on guard. 
If there are two of them, one may try to reach camp to awaken the relief men. Often he gets lost in the darkness and never finds camp, so the men on guard are forced to stay with the herd until daylight.

The roundup thus progresses around the range until the work is over, and the steers which are to be shipped are cut out. The other stock, which has been carried

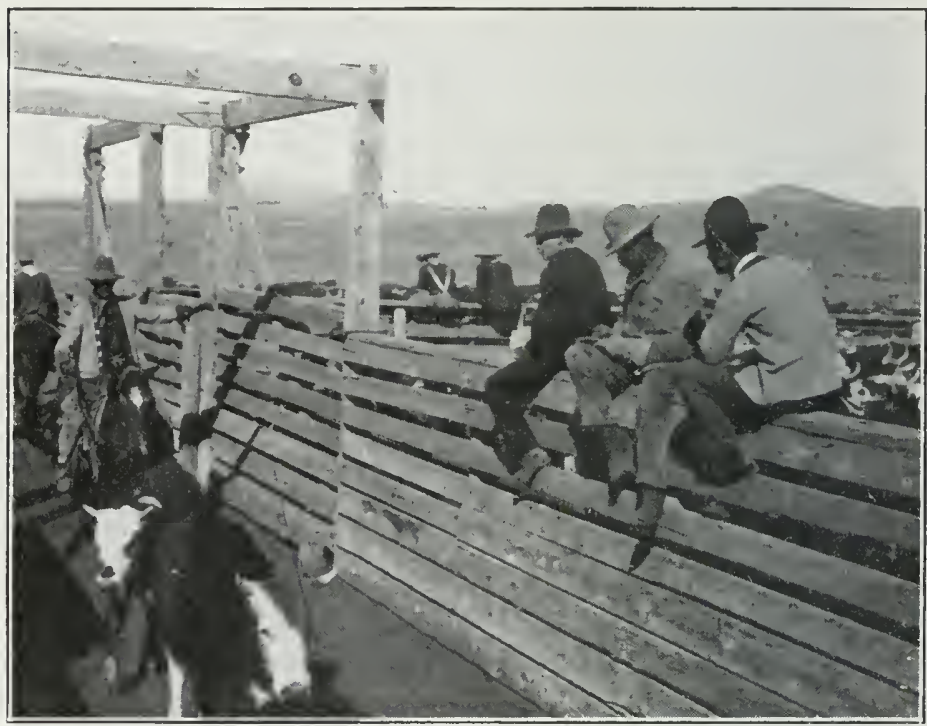

Western Inspectors Examining Brands of Steers.

along for various reasons, is cut out, and the stray men, as the men from the other ranges are called, drive off with their cattle to their own ranges. The steers are taken to some shipping point and loaded onto cars for their destination.

Brand Inspectors.-At the stockyards the steers are classed according to their brands and ages. A keen-eyed 
inspector is there representing the state, to take down all the brands and see that 110 strays are shipped, thus protecting the interests of the men not present. All brands for which there is no owner are cut out and turned loose or else shipped by the inspector and the proceeds turned over to the state authorities to be held for the rightful owner. In certain sections there is also an inspector of the Bureau of Animal Industry who looks

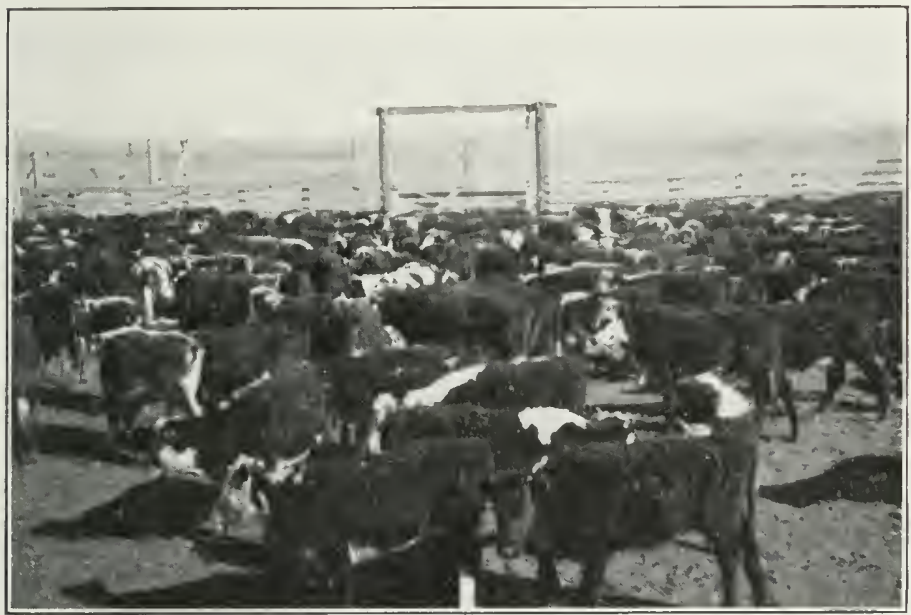

Yearling Steers in Yards at Magdalena, N. M., Awaiting Inspection,

the stock over carefully for evidences of discase, especially Texas ferer ticks and mange.

Loading for Market.- After passing the scrutiny of these inspectors, the stock is loaded on cars and goes to market. A 30-foot car is the standard for stock cars but 36 feet is the favorite size, while of late years some of the railroads have built cars up to $t 0$ feet.

The animals are crowded into the cars as tightly as 
they can be and still give room enough to get one up if it gets down. A 36-foot car will hold above forty average two-year-old steers, thirty-four cows, fifty-five or sixty yearlings or 110 calves. Twenty-eight three- and four-year-old steers will make a good load. These figures are for average southern stock and are not given as hard and fast rules, but simply to show about how much stuff is ordinarily loaded. The length of the run, the condition of the cattle, and the judgment of the shipper are all to be considered.

Care is taken not to give the stock water for at least twelve hours before loading, as it keeps the cars from getting sloppy and slippery, resulting in the animals getting down and being injured by the others tramping upon them. Such animals are in stockyard circles known as "downers."

Once in the cars they are not unloaded until they reach a regular feeding point, and as the Federal law now requires them to be fed and watered at least once in twenty-eight hours the runs must be planned to meet this law.

Loss of "Downers."-The men in charge of the cattle endeavor to keep them on their feet and do not allow them to lie down. This is because if one lies down the others will fall over it and trample it, bruising and often killing it. If one does get down the man prods it until it struggles to its feet. Sometimes when the stock is weak, in the spring shipment it is necessary for the shippers to get right down into the car and fight the cattle off the prostrate animal until a place is cleared for it to rise. Many a shipper of this class of cattle spends hours riding in the cars while the train is running keeping 
a weak cow or steer on its feet, or the others from trampling it until he can reach a feeclyard and unload.

In bad years, when the cattle from the South are weak, the losses are enormous. 'Ten per cent is not an

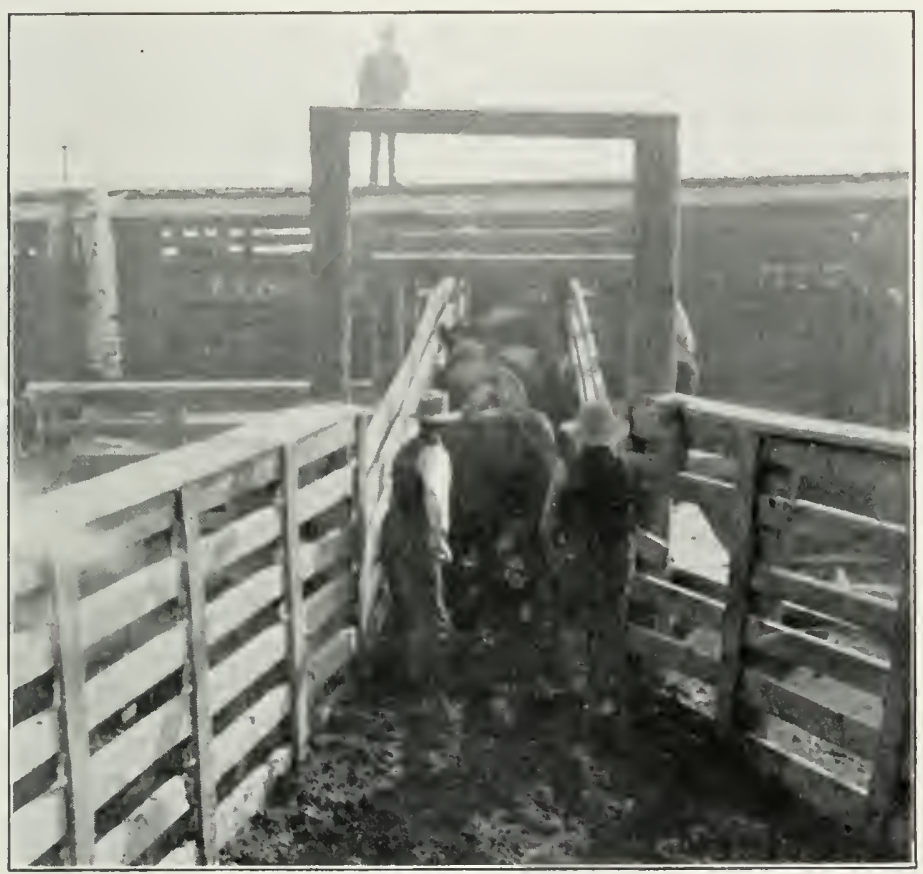

Loading Fat Steers in Colorado.

infrequent average loss on a shipment where the cattle must be shipped out to save them from starvation.

From the northern ranges the steers are all shipped out fat and heary and are easily handled. Everything is done to retain the fat which they have on them and woe betide the reckless puncher who runs a bunch of 
them or hurries them unnecessarily along the trail. They are loaded with every possible care, and as they are strong they make the shippers very little trouble.

Hay-fed Cattle.-In some parts of the IVest, notably western Colorado, stockmen are raising a very superior grade of steers known to the trade as hay-fed cattle. They are commonly southern steers brought up early in the spring and turned out on the mountain ranges, mostly within the limits of the various National Forests, and grazed on the ranges until snow flies in the fall. They are then taken to the home ranches of the owners and fed native hay to finish them for market.

Under such conditions these steers take on flesh very rapidly and furnish the markets with a supply of steers before the corn-fed cattle are ready for the trade. This business is a growing one and while it has been developed to a very high degree in Colorado, it is followed in many portions of the IVest where the conditions are right. By conditions is meant the proper ranges for the summer months, such as are found in the higher mountains of the Rocky Mountain region, and hay meadows where the native hay can be grown at slight cost. The fact that most of these hay ranches are in such localities that the hay would probably not find a market except through the mediun of the cattle, makes the business all the more profitable.

The Humboldt and Reese River Valleys in central Nevada are other districts where hay feeding has been developed to a great business. Nost of the Nevada cattle are shipper west to the coast, principally San Francisco.

Rule for Measuring Hay.-Is forest officers frequently purchase hay in the stack, some rule or method 
of measurement is repuired to determine the contents of a stack in tuns. In the Southwest the army officers purcliasing hay for the army posts formerly used what is known as the "Government rule," with satisfaction to both sellers and buyers. After using the rule for many years, both for buying and selling hay, during which time I tested wut the measurements. Dy baling from a measured stack and then weighing the bales, I satisfied myself that the rule was fair and reliable, and when I became a member of the New Mexico territorial legislature introduced and passed a bill making it the legal measurement for liay there. It has stood the test of several years since then, and given general satisfaction. The New Mexico rule is as follows:

Multiply the width in feet by the over, divide this moduct by 4 and multiply this dividend by the lengtl. This gives the contents in cubic feet. For hay that has stood not over 30 days, divide by $512 ; 30$ to 60 days, by 422: over 60 days, 380, which gives the tonnage of the stack.

Example: Stack is 20 feet wide, 40 over and 60 long: $\quad 20 \times+10=800 ; \quad 800 \div 4=200 ; \quad 200 \times 60=12,000$; $12.000 \div 512-231 / 2$ tons.

The principle on which this rule is based is that the face of the stack represents a half of a perfect circle. and while not every stack is such in its measurements, the shapes differing with erery stack, the average of a large number of stacks will fall clearly within that principle. In measuring the "over" of course care should be ised to find a fairly representative place so as to obtain a fair average of the entire stack. 


\section{CHAPTER VI.}

\section{HANDLING SHEEP ON THE RANGE.}

There has been a great development of the sheepraising industry in the Rocky Mountain states during the last ten years. The tariff on wool placed the business upon a stable basis and at the same time a rapid growth in the call for mutton became apparent. $U_{p}$ to ten years ago the American people could not be said to he a mutton-loving people.

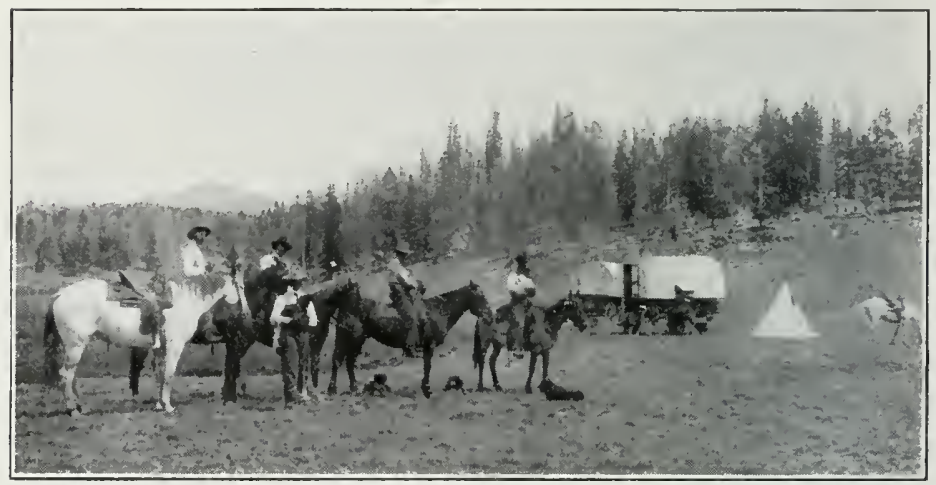

A Sheep Wagon or Camp on Wheels in Wyoming.

The sheepmen fostered this interest in mutton by turning attention to the breeds of sheep that were noted for the quality of their mutton, such as Shropshires, Southdowns and those breeds known as mutton or open-wooled sheep. Up to this time wool was the sole object for which they raised sheep, mutton being a side- 
issue. It was found that sereral of the breeds were well fitted for range purpuses, and sheepmen introduced the new blood into their lerds with remarkable success.

Lamb Feeding. - Mbout this time the sugar beet growers around the beet sugar factories in southwestern Colo-

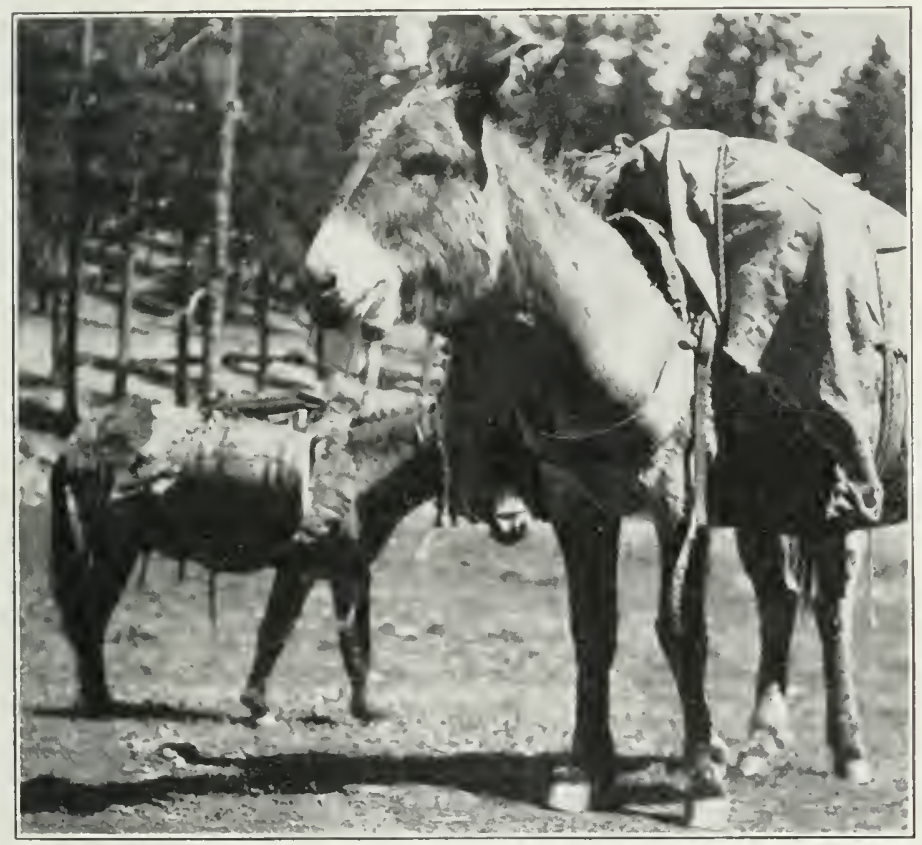

An Arizona "Sheep Wagon"-Burro Packed With Grub and Water.

rado found that they must have some fertilizing agent for their beet lands. They had immense quantities of alfalfa hay for feeding purposes, and the business was entered into in a small way at first. It was quickly discovered that the feeding of lambs for the winter market was a business of great possibilities. 
The lambs could be purchased in New Mexico and Arizona at reasonable rates, they fed well, were extremely healthy and easily handled. Since they were kept in close feedlots, the droppings were easily taken care of and as a fertilizer, made a source of income from the investment in addition to the profit in the growth of the animals. This business grew by leaps and bounds, and the price of feed, especially alfalfa hay, went soaring. The feeders also found that they could import corn from Kansas to add to the ration with excellent results.

Rise in Prices for Lambs.-The great demand for lambs worked the prices up until the New Mexico sheep men were able to contract their lamb crop at prices which seemed enormous, looking back to the beginning of the business. From a price per head the trade went to a pound basis, and New Mexico lambs have been sold as high as $5 \frac{1}{2} 2$ cents per pound at the loading point. Fortunes were made by shrewd speculators who went to the lamb raisers and contracted for their crop, shipped them into the feeding districts, and retailed them to the feeders in small bands at good profits.

Coming into the eastern markets, as these western-fed lambs do, at a time when the normal supply is at the lowest point, they find a ready sale.

Advance in Wool Prices. - Tith the increase in mutton values came a great rise in wool. During the years of free wool the western wool-growers were forced to sell their crops at rates which gave them no profit on their investment. Some western wools dropped as low as 6 and even 5 cents a pound, and the arerage for several seasons was below 10 cents.

In the last few years the growers have considerably increased the weight of their shearing. The price of the 
product has more than dublbed, western wool having sold as high as 25 cents per pound in the summer of 1909 . which was the maximum for recent years.

Increase in Cost of Production.-With the increase in prices, howerer, has come a material increase in the cost of raising. Herders' wages are higher than they were ten years ago. Shearers receive much more than they formerly were paid, and although machine-shearing has come into rogue on most of the ranches, enabling the owners to handle their flocks much more expeditionsly than in former years, the average cost of the two methods is however approximately the same. An average hand shearer will clip sixty to seventy sheep per day, while the improved machines enable a shearer to handle 200, and some exceed this, the Australian record being 316 sheep in an eight-hour day. The profit in machine shearing is, however, in the rapidity with which a band can be shorn and returned to the range.

More provision is made for winter than in the old days, and large sums are spent by sheep-men in providing haystacks in order to guard against losses from that source.

Grazing Leased Land.-The increase of settlers upon the open ranges has forced the sheepmen to lease private lands on which to graze their herds, and large areas of railroad lands upon the winter ranges in the mountain states have either been bought outright or else are leased by the wool-growers. They banded together to lease these lands in huge tracts, and then parceled the ranges out among themselves, according to previous agreements.

The best example of this sort of co-operation is in the celebrated Red Desert country in western Wyoming 
and eastern Utah, where the sheepmen have established themselves upon the winter ranges to the almost complete exclusion of all other classes of stock. In California, Oregon and $1 \mathrm{~T}$ ashington, especially in the mountains, the railroads and great syndicates that control the timber lands in large tracts, have all leased their lands to the sheepmen for summer grazing.

This naturally has added to the expense of raising sheep, but the men who have been long-headed enough to look thus far into the future, have placed their business upon a solid foundation.

Double Profit From Sheep.-The woul-grower has one great advantage over the man raising cattle in that he has two yearly crops upon which to depend. If his lamb crop is a failure, he still has his wool. If wool is low, he can meet the deficit in his income from the sales of his lambs. Seldom are both low at the same time. Sheep are also more closely under the eye of the herder and thus more safely cared for in bad weather or trying times. The Mexicans have a saying that, "the old ewe even in her death leares her pelt behind to pay the funeral expenses."

The increase is also much heavier than in cattle. In the southwestern lambing grounds under almost ideal conditions for lambing a careful shepherd has been known in more than one instance to lamb and "mark u1p" a full 100 per cent crop, or a lamb for every ewe. In the Salt River country in good years instances have been known where a herd of 2,000 ewes has averaged 105 per cent. In the same region, on alfalfa and lambed under most careful supervision, out of 250 young ewes an arerage of 150 per cent or 375 lambs has been raised. Taking 


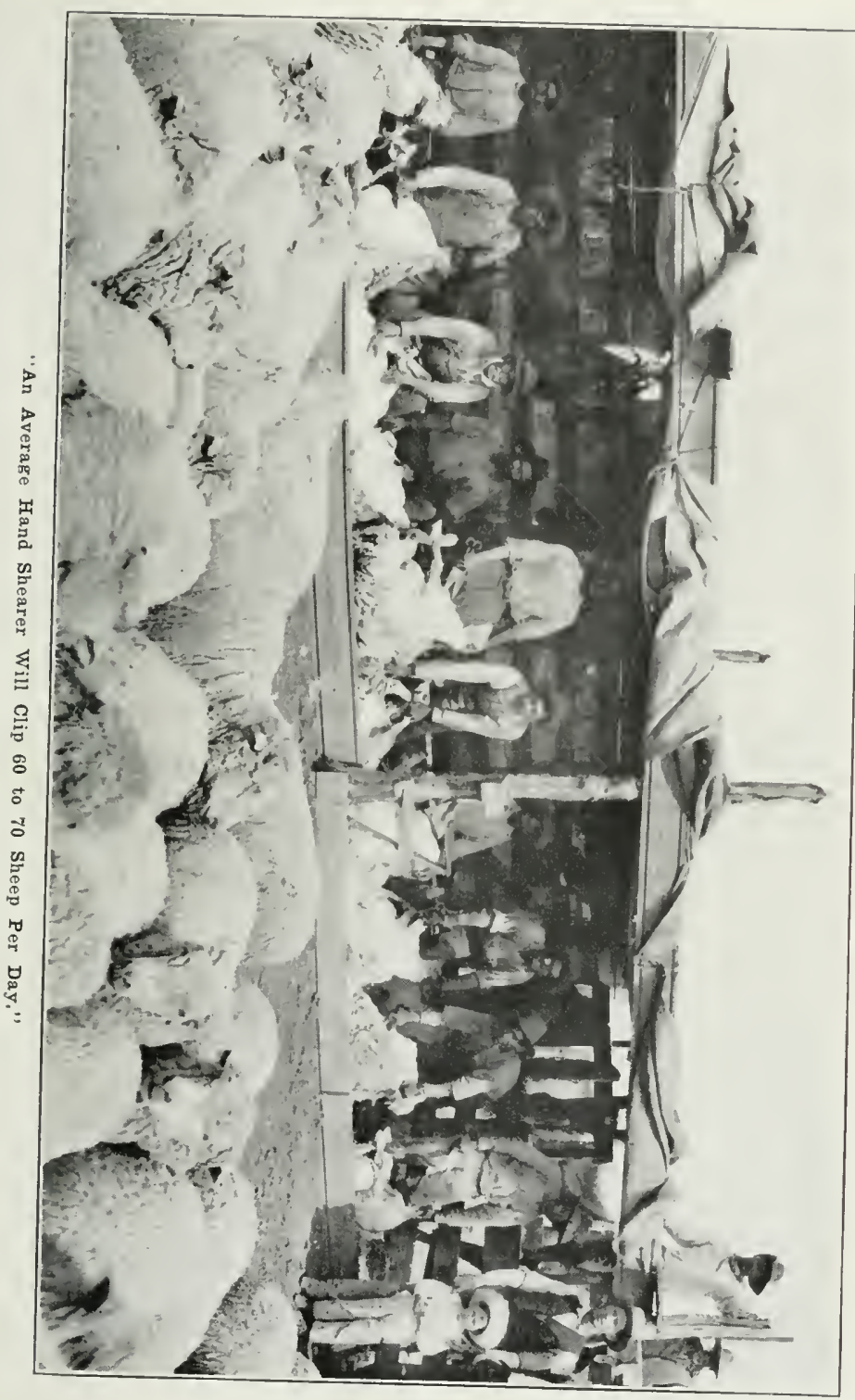




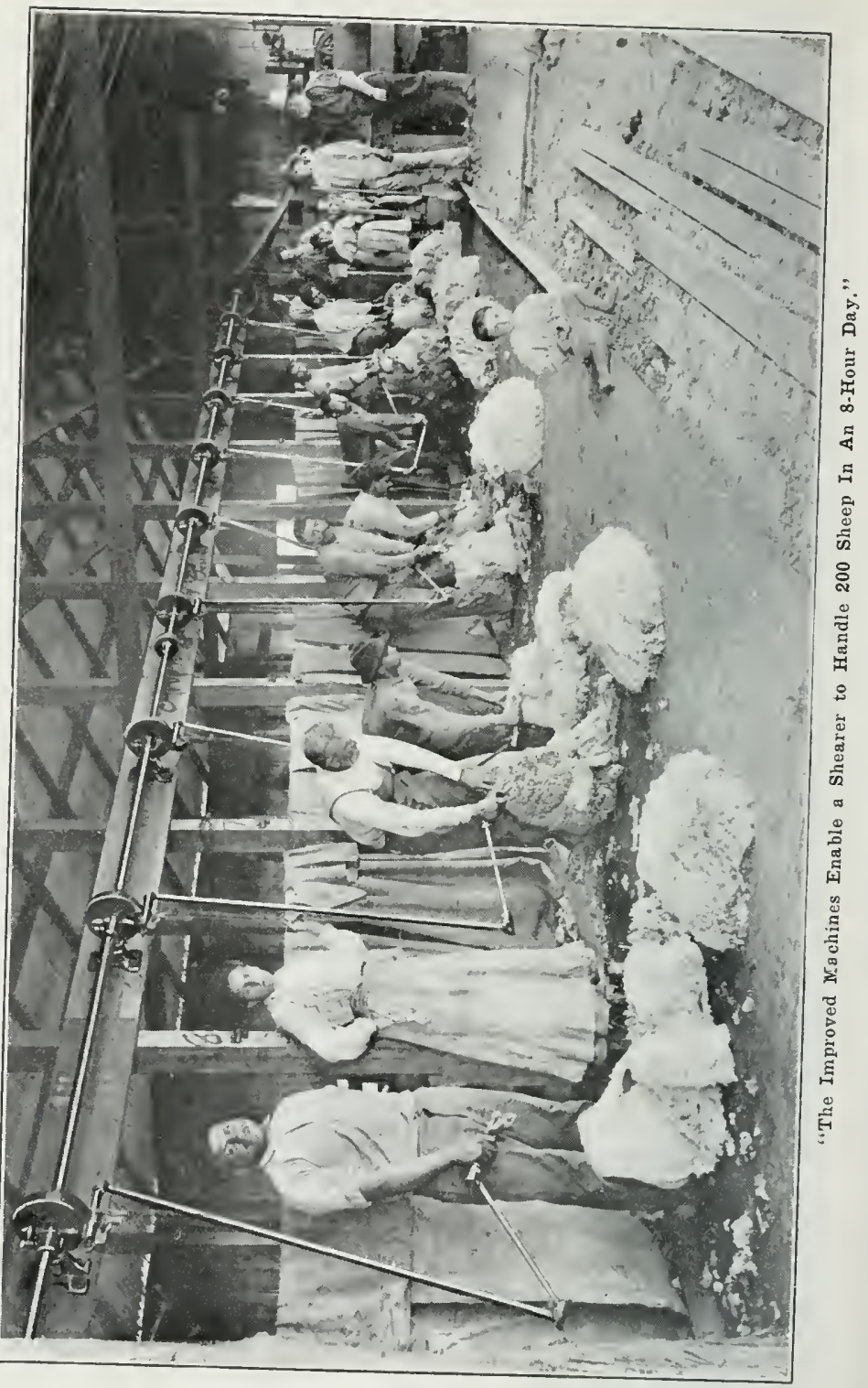


the combry wer, howerer, an arerage lambing of 70 per cent is about the correct figure.

There is a tendency among the better breeds of stock to drop down on this average. The highest percentages are fonnd among the herds containing some connum blood. These animals seem to bear twins and even triplets and raise them with great regularity, but as soon as improved rams are introduced into the herd the number of twins rapidly decreases. Not only is the number less but it is well known that the better bred ewe is not so safe a mother as the common one. being apt to desert one, if not both, of her offspring.

Time of Shearing.-Just before the lambs are born the sheep are sheared. Some owners shear twice each year, in the spring and again in the fall. There is a great variety of opinion as to the wisdom of this and much depends on the range and the weather conditions. On brushy rough ranges where the wool is likely to be torn from the sheep's backs as they graze, it is wise to shear twice. On open ranges where this does not occur the sheep can carry the year's fleece with little loss, and as a general thing shearing but once a year, and that in the spring, is the prevailing system. In California they are forced to shear twice owing to the awns from the needle, porcupine and foxtail grasses which get into the wool. Heavy winter rains also make it advisable, the sheep suffering from the wet wool.

Serious losses often follow shearing in either spring or fall from sudden changes in the weather. Of late years the more progressive sheepmen keep on hand in the camps small blankets of light canvas and if the weather turns stormy, after shearing each animal has a blanket tied to its back which takes the place in part of the wool 
which they have lost. A band of sheep thus corered offers an amusing signt with the flapping blankets waving in the wind, but they have saved their owners many thousands of dollars in the last few years. In the old happy days of the business this would have been latighed

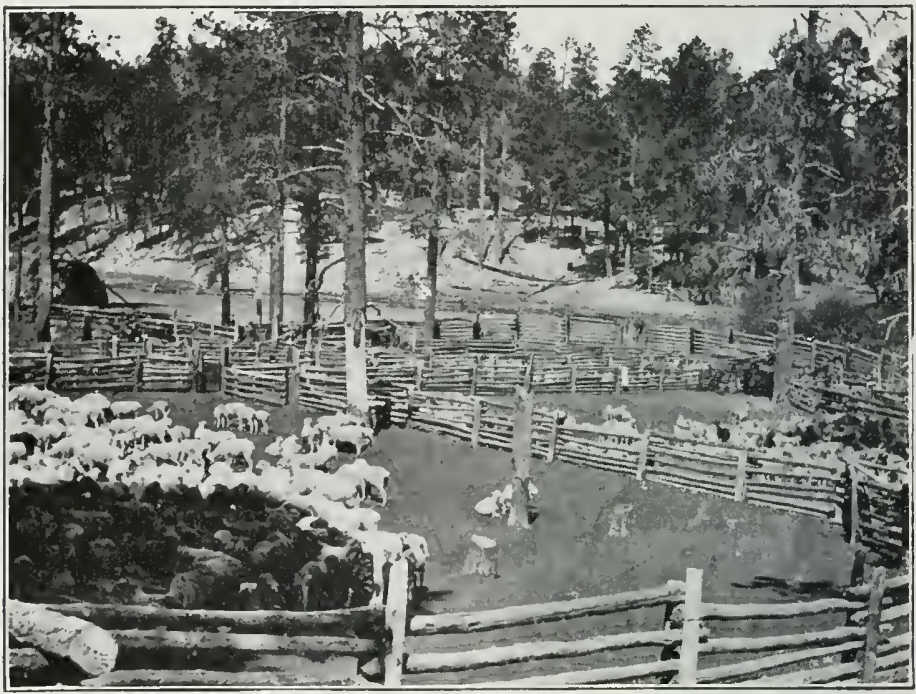

Pens and Yards in Which Sheep are Dipped and Handied in Northern Arizona.

at, but today the careful sheepmen cannot afford to neglect such precautions.

Weight of Fleece.-The average clip raries with the states. In the Southwest the arerage is probably about $6 \mathrm{I} / 2$ pounds, while in the Northwest it is about $7 \mathrm{I} / 2$. The average for California is close to 9 pounds, doubtless due to the habit of semi-yearly shearing. which seems to make a more rapid growth of wool, but it does not command so good a price, owing to its short staple. 
Dipping.- - Ifter the spring shearing the sheep are generally dipped as a precautionary measure. The dipping rids the sheep of ticks and lice as well as scals parasites and, it is said, improves the grade of wool. This latter point, however, is mot accepted by all woolgrowers as being true.

Time of Lambing. - The ewes are bred so as to bring the lambs as early in the spring as will be safe. In the

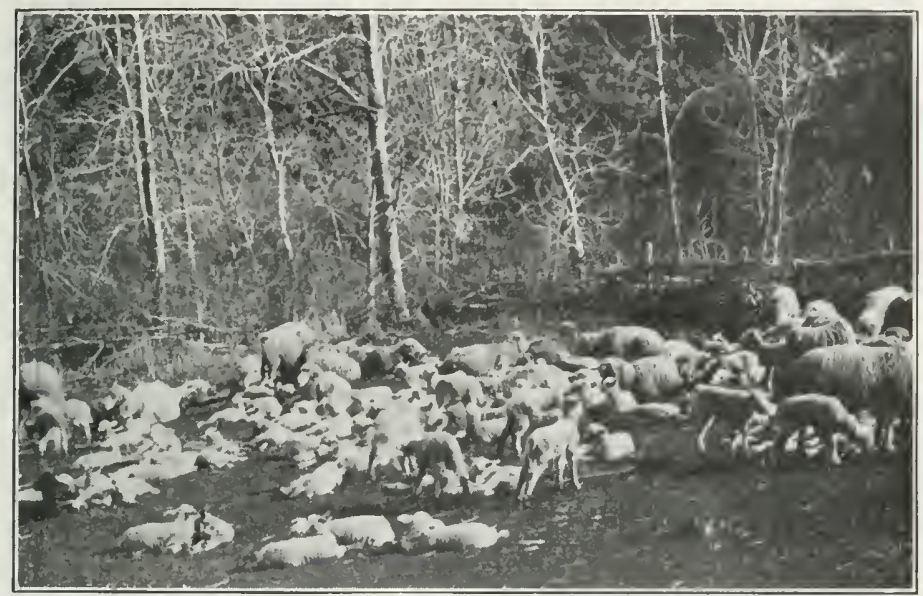

A Band of Range Lambs and Ewes On a Hot Day.

Southwest the sheepmen who take their herds to the Salt River Valley on the alfileria deserts breed their ewes to lamb in February and March. In Arizona, New Mexico and Texas the general lambing season is between the middle of April and the middle of May. In the northern ranges the lambing season is somewhat later, owing to the fact that the lambing grounds are not always available, being too wet to use on account of late snows. 
Lambing Grounds.-The lambing season is the sheepman's anxious period. For this reason the ownership or control of good lambing grounds is one of the first requisites to a successful sheep ranch. The lambing grounds should be sheltered spots open and free from underbrush and rough places. Water must be plentiful and easily reached and the grass should be some of the early-growing nutritious kinds. They should be

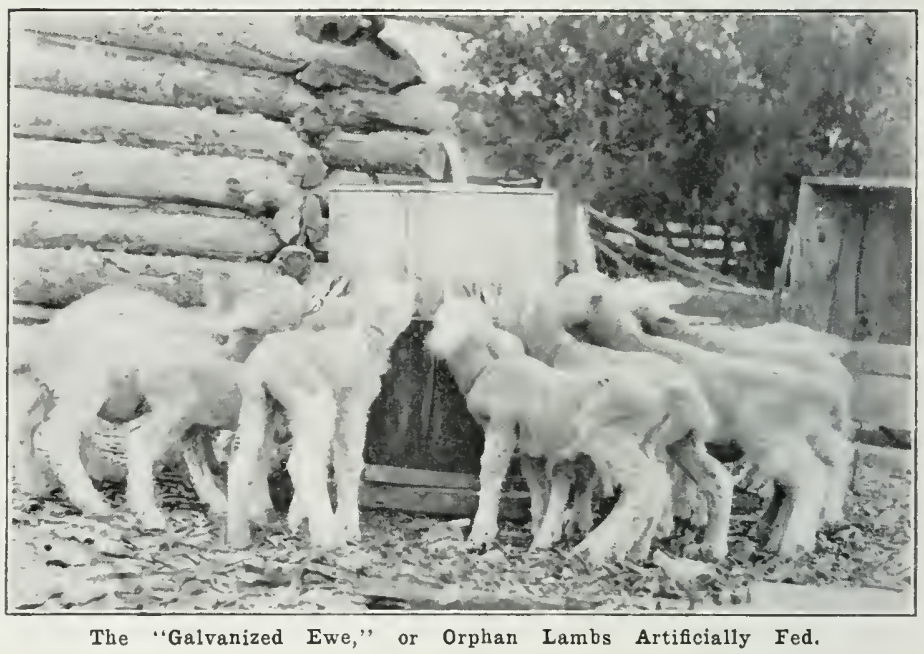

free from prairie dog and badger holes, for many a tottering little lamb has fallen into such a hole and perished.

Here the ewes are handled with the greatest care. Extra herders are employed in order that the bands may be broken into small bunches. The ewes are left undisturbed, so far as possible, and every precaution taken not to worry or frighten the animals.

The Herder's Work.-A good herder will carefully watch every ewe and see that she owns her lamb. All 
sorts of devices are used for this purpose. If a ewe refuses to own the little one the herder takes it up in his arms and carries it to the main corral or pens. There very small pens just large enough for one ewe have been built, and in these the ewe and little one are placed. Sometimes a sullall pit or hole is dug into which the ewe and lamb are put and an old sheepskin or gunny sack placed over it. In the darkness the lamb will prohably find what is necessary to satisfy its hunger and in a few hours they can be taken out and turned with the band. As fast as the ewes claim their lambs and seem to be content they are pushed carefully together and thrown into a small band, called the "wet band," but for some days they are handled very tenderly and moved as little as possible.

Sometimes the mother dies and there is an orplan left on the herder's hands. If he has some old sedate ewe he probably coaves her to take the mphan in addition to her own. Again a ewe with twins will not be giving milk enough for botl. If a herder is looking after his band he will have one eye on some ewe whose lamb has died. By means of the dark pit or the small pen he will force her to mother the weakling. Sometimes he will skin the dead laml, and fasten its hide to the twin, and the ewe, knowing her lamb wholly by the sense of smell, noses the dead one's hide and accepts the stray withont further ado. Where cows' milk is available many an orphan lamb is raised on the bottle or by other artificial means. Netal harrels supplied with a line of nipples set around the outside are filled with milk and the lambs taught to go to it for food, which they readlily do.

Marking, Castrating and Docking.-This process is 
generally done at the same time, when the lambs are about three weeks old, and seldom causes any losses among them. The marking is done as with calves, and most sheepmen use different marks for the sexes, so as to aid in picking out the wether lambs from the band when they are wanted.

The castrating is also done exactly as with calves, although some operators after cutting. off the end of the bag or scrotum place the lamb over a $\log$ or the top rail of the corral, so as to be just at the right height, gral, the protruding testicles with the teeth and pull them out until the cords break. In this way the work is performed with remarkable rapidity.

In docking, the tail is laid over a $\log$ and with a sharp hatchet, chisel or hunting knife is taken off so as to leave a stump about four inches long. Occasionally a lamb is fly-blown in the end of the docked tail, but ordinarily the wound heals up rapidly. Nothing is put on it to cure it unless it is a little pine tar, which some sheepmen use to keep the flies away.

Night Herding.-Often it is necessary to leave a large number of ewes out all night on account of the lambs being too weak to follow in to the main camp. In such cases the herder works them as closely together as possible and a night man looks after them during the night, keeping fires burning and in some outfits cowbells an:l lighted lanterns are hung about in the vicinity of the sheep to frighten away any prowling coyotes or bobcats. Many owners furnish fireworks to be set off at intervals during the night for the same purpose.

Following the Drop Band.-Some owners employ men especially to carry in the smaller lambs. They follow the drop band about and as it works toward the main 
camp will pick up any freshly-born lamb and while the ewe is carried along with the herd this man will follow with several lambs. When they reach the bed ground the lambs are placed in a small corral, the mothers picked out of the herd and placed with them. and by morning they have generally owned their progeny.

Lambing in Tents.-In Oregan and some of the other northwestern states a system of corral lambing is

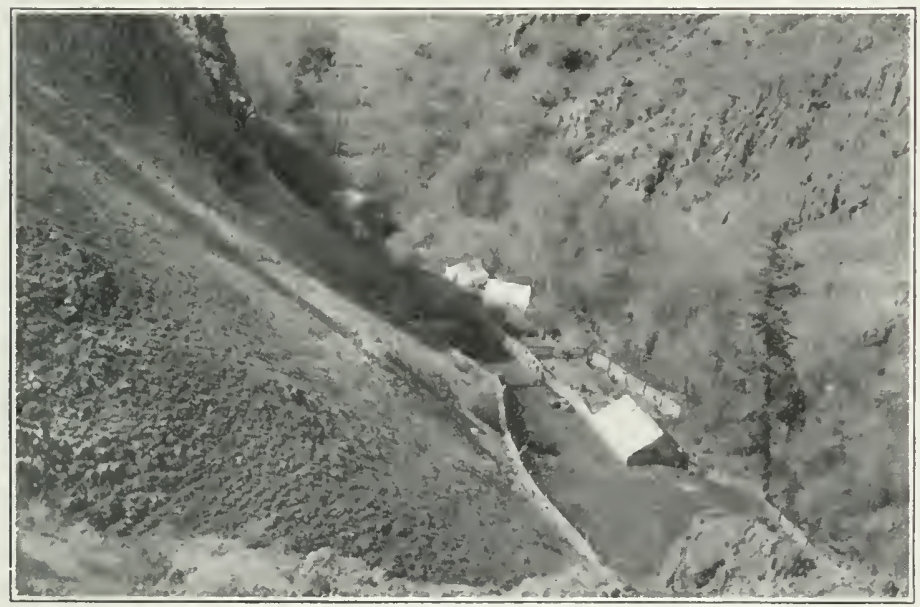

A Lambing Tent in Oregon.

followed, owing to the danger of storms during that time. In this case a large tent is erected inside of which the ewes are placed that are likely to drop their lambs during the night. This tent is large enough to accommodate a good many sheep and often two sheet-iron? stoves are used to keep the interior at a comfortable temperature. The lambs are carefully watched and each band is kept close to the tent so that in the event of a storm they may have the benefit of the shelter. In this 
way many lambs are saved that in the usual course of lambing would be lost and a careful herder will raise a full percentage of lambs where one who is indifferent will cost his employer ten times his wages each day.

A Critical Period. - With the ordinary herd the lambing should be over in from ten to fifteen days, when they can be thrown together and left in charge of the regular herder. Lambing is a critical period for the sheepman and a few careless herlers or an unexpected storm may cause him to lose the entire year's profits in a very short time. For the owner or foreman it means twenty-four hours of almost constant work every single day. For herders it means long hours also and a loyalty to their work which is sometimes paid for with their lives when a snowstorm overtakes them and rather than abandon their charges they perish with them.

Moving to Mountain Pastures.-As soon as the lambing is safely over the ewes are noved into the high monntains in order that they may liave the very choicest of green food. Sheep do not feed entirely upon grass but eat many varieties of weeds and forage plants. Nor do they need water as horses and cattle do. Sheep grazing on the high Alpine meadows will go for sereral days without being watered, finding all the moisture they need in the early dews and in the soft lush feed. Of course much depends on the quality of the feed, the amount of dew and the weather. In northern Arizona I have known bands of erres to go for ten days without going to water, and when they did reach it they drank very little.

Weight of Lambs.- Lambs raised nuder these conditions grow very rapidly and at eight months should weigh more than 65 pounds. The average weight of 
southern lambs is probably a little less, while in the Northwest in Idaho, Oregon and Utah lambs will no (loubt average more. But taking the lambs all over the western ranges 65 pounds will be very close to the shipping weight when they are loaded for the feeding points in the fall. If the sheep are to be sheared again in the fall this is done after the lambs are shipped, and then the herds are sent to the winter range. The rams, or

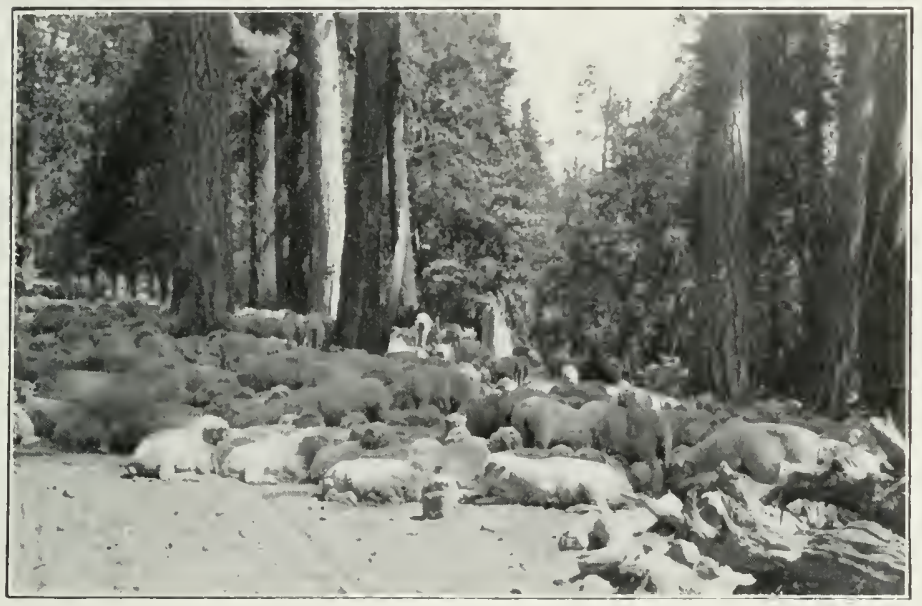

In Heavy Timber "Cuts" May Occur, and the Band Should Not Be So Large As On the Open Range.

"bucks," are placed with the ewes along in December, according to the time when the lanbs are desirel. As the ewes carry their lambs five months it is a question for each owner to kecide for himself, according to his judgment and the location of his lambing grounds.

The bucks are kept by themselves during the summer, several owners often throwing their bucks into one band and employing one herder for the purpose or renting a pasture where they can have the best of care. 
During the breeding season the bucks are worked in relays, one lot being turned in with the ewes while the other is kept in a pen and fed corn and sometimes hay to keep then in the best of condition.

Shipping the Sheep.-Sheep are shipped in doubledecked cars and require great attention from the shippers during the time they are on the cars. The main thing to be watched is smothering when they are crowded into one end of the deck by the sudden movement of the train.

Sheep are undumbtedly the least intelligent of all domestic animals. For this reason the work of loading a train of sheep is frequently a very tedions operation. At most of the large shipping points where many sheep are handled trained goats are kept for loading sheep. The goat gravely walks to the entrance of the chute and at the command of the shipper starts slowly up the chute to the car door. The foolish sheep follow him and, once inside, the goat hurries around the side of the car and coming to the don stands there while the sheep pour in a stream after something, they know not what. When the load is all in, the man calls the goat and he slips out the door and down the chute to reneat the operation with the next load.

Sheep are subject to the same laws for unloading and feeding as are cattle, although there is grave doubt as to the wisdon of the law. the frequent loading and unloading being more injurious to the stock than the long hours without feed and water. This is especially true of lamhs. which will not feed much nn the road, being cut off from their mothers so recently that they must be starred into trving other feed.

Size of Bands.-Tn handling sheep on the ranges they 
are generally cut into bands of from 1,500 to 2,500 hearl, the size of course depending upon the range. If it is rough and broken, a band of 1,250 ewes and their lambs is all one lierder can safely handle without losses from cuts.

On the average ranges in the western mountains. a good herder can care for 2,500 dry sheep or wethers, but in a country cut up by canyons and broken areas he should not lave more than can be grazed under his

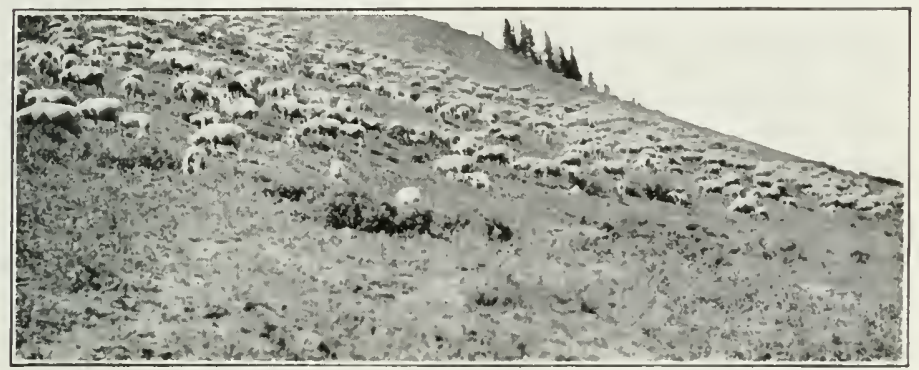

A Herder Can Look After Many More Sheep On An Open Range Than On a Broken Range.

eye at all times. On the winter ranges, which are mostly on the open deserts, goul herders successfully handle as many as 3,000.

With each outfit is a camp rustler, or tender, who goes ahead of the sheep, picks out a camping place, keeps the camp stocked with food and supplies, leaving the herder free to lonk after his sheep. Where one owner lias several bands one rustler can take care of more than one.

Bedding Down at Night.-The sheep are seldom corralled at night, being simply bedded down near camp. Thus handled they are much less liable to loss from smothering in wild senseless stampedes during the night. Wild animals also cannot do as much dam- 


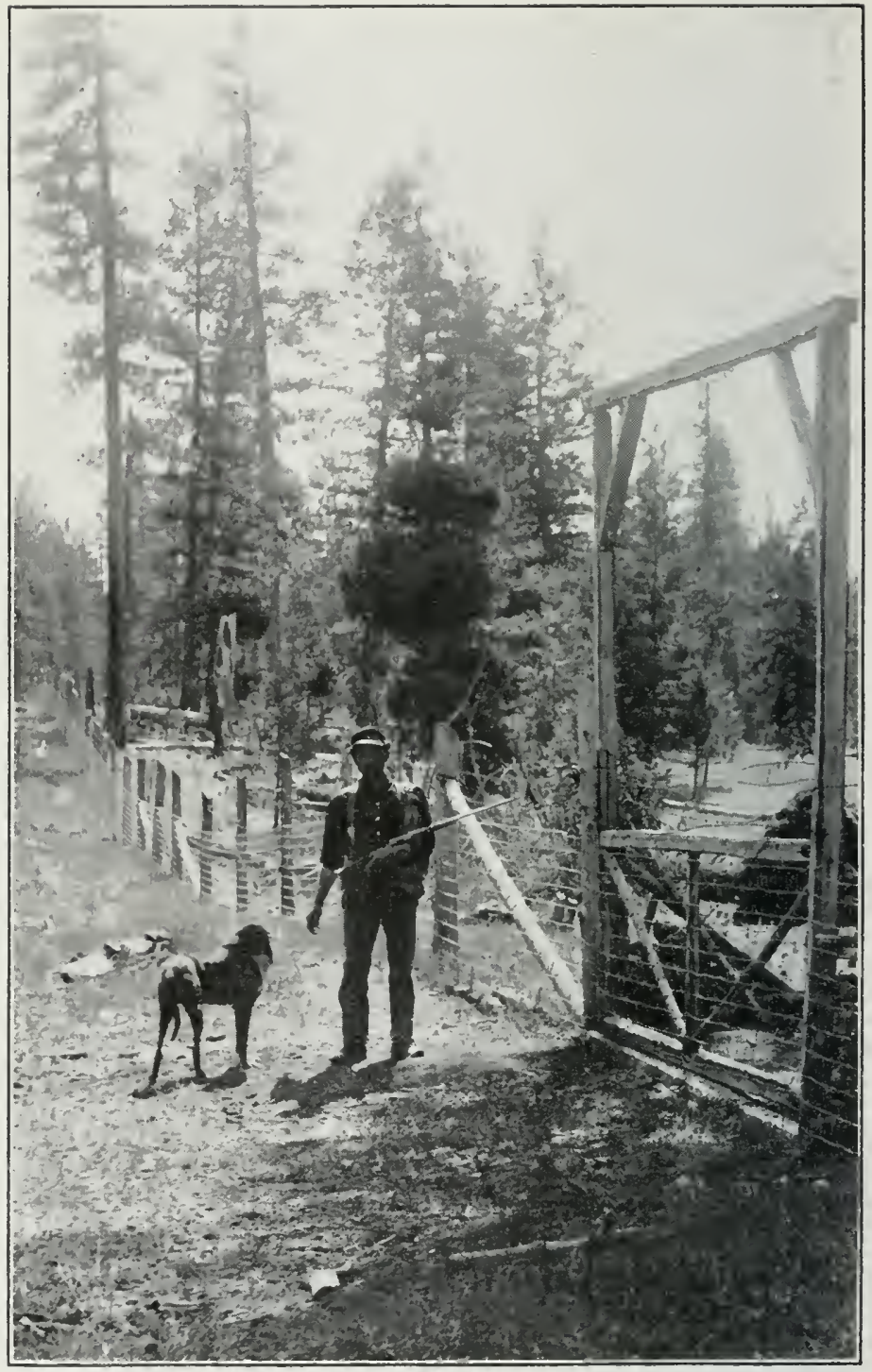

A Coyote-Proof Fence in the Wallowa Mountains. 


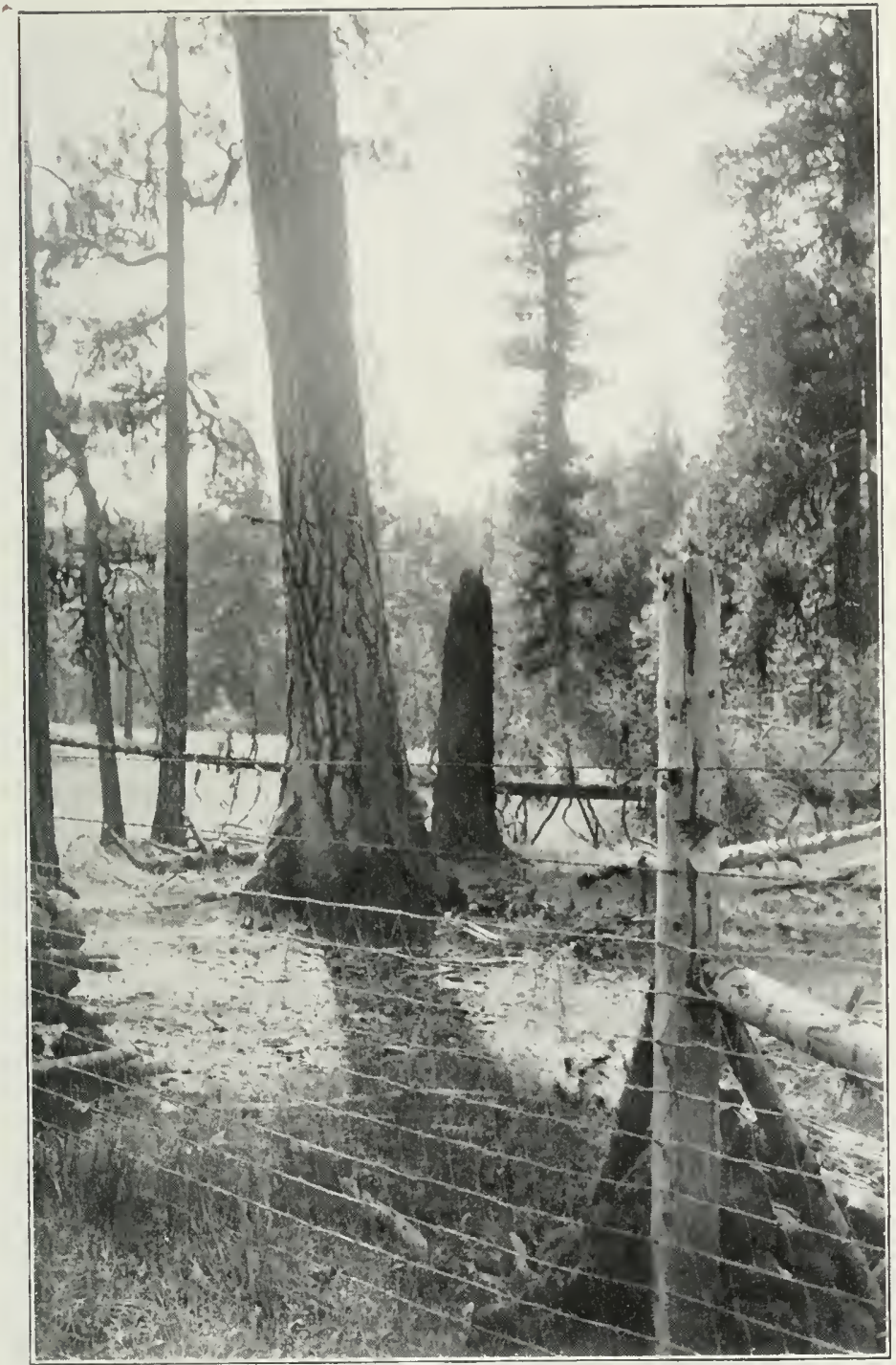

Built by the Forest Service in Oregon. 
age where sheep are outside of a corral and are free to run from danger of that kind.

A watchful herder if he hears his sheep run during the night will whistle shrilly, fire a shot from his gun, or shout at them. The sudden noise stops their mad flight and after listening a moment they settle down again in peace and quiet, forgetting their fears.

Sheep in Fenced Pastures.-In Australia for many years past they have been raising sheep in large fenced enclosures. One mounted herder frequently looks after as many as 10,000 sheep in one pasture or in several contiguous pastures. Recently the Forest Service has been experimenting on this plan, with such excellent results that many sheepmen who have the necessary anount of land are doing the same thing. The fences are built to be proof against attacks of coyotes and dogs. Bear and probably wild cats can go through or over any fence that can be built but the coyote and stray dogs are the most dangerous enemies with which sheepmen have to contend.

Raised inside such enclosures, it has been settled beyond doubt that the wool crop is heavier. the lambs grow faster and weigh more, the loss from death by accident is less and best of all a given area of land will carry 50 per cent more sheep under fence than when herded. The average loss from accidents in a herded band is 3 per cent, while in a fenced enclosure it is less than 1 per cent. Lambs grazed nuder a fence weighed 15 per cent more than the same grade of lambs grazed under a herder on the same range. Taking all these things into consideration, raising sheep under fence where the cost of the fence is between $\$ 200$ and $\$ 300$ per mile, will pay good interest on the outlay for fencing. 


\section{CHAP'TER VII. \\ GOATS ON THE RANGE.}

The raising of Angora goats in the last few years has becone quite an industry. In the W est, especially the Southwest, there are many areas well fitted for grazing goats. Contrary to general opinion, raising goats is not a matter of luck, and the man who buys a band of goats and expects them to live on tin cans and scenery will be badly fooled.

Kids Are Tender.- While the Mexican goat is a hardy animal, the Angora is very delicate in many ways and requires great care at certain periods of its life. The kids are especially tender for the first few weeks and nunst be given careful attention from the day they are born up to six weeks of age. After that they will take care of themselves with little trouble.

Little Herding Needed.-Goats require little herding, and can be turned out on the ranges and left to themselves day after day. They will come home at night as regularly as the milk cows, and take good care of themselves against wild animals.

Of course no good goat-owner will allow his goats to look out for themselves all the time. Still the constant attention of a herder is not needed as it is with sheep. Goats must have sheds to protect them from rain and storms. They seem to dislike the wet and 
many are lost by early storms while away from the sheds. On account of the nature of their foud-browsegoats require twice as much salt as sheep.

For the first few weeks the little kids are not allowed to go out on the range with their mothers but are kept at the ranch in a yard or corral. During the kidding time the does are handled much as are eves. Several

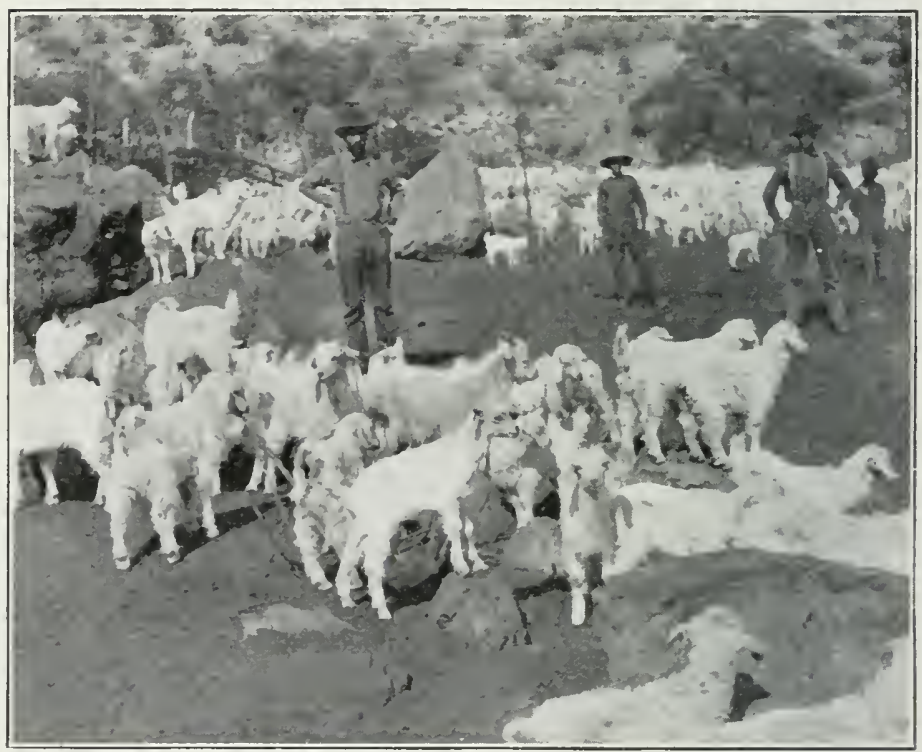

A Pen of Angora Kids in New Mexico.

methods of taking care of the little fellows are followed. Some owners stake out each kid with a small string tied to a leg and a peg driven into the ground. The does seem to know only one place to find their offspring, and if left alone the kid will wander off and the doe never find it again. Py tying them to stakes they are held fast and the does come and go at pleasure. 
Other men keep them in pens, where the top rail is just high enough to allow the doe to ju111) over while the kid cannot. This allows the doe to go back and forth at will, and is of course much less trouble for the herder than staking the kids ont.

It is generally conceded, however, that the men who use the staking systen raise a much higher percentage of kids than those who use the pen method.

There is nothing nore beatiful than a thousand little Angora kids, lying like a snow bank on the smmny side of an enclosure. With their beantiful silky, curly hair and long pendulous ears they are about the sweetest, cleanest things imaginable.

Common Goats Breed Best.-Like sleep, howerer, the higher the grade the less mumber of twins and triplets. Take a band of common Mexican does and it is no nuconmmon thing to raise 150 or 1110 e kids to every 100 does. But when you begin to improve the goats the does seem to lose the ability to bring forth more than one kid at a time, and like sleep the losses from stillborn young and other canses during pregnancy is much greater in the high-bred than in the scrub goats.

Shearing and Dipping.- The Algoras are sheared generally once a year, as with the sheep much depending on the range and the weather. Goats are not subject to scab but the best and most successful goatmen dip their animals each spring to clean ont the lice, ticks and other vermin that infest them. 


\section{CHATTER VIII.}

\section{DETERMINING THE AGE OF STOCK.}

Almost everyone knows the old story about the tenderfoot who took up the bet that a certain youngappearing cow in the herd was "so old that she did not have a single front tooth in her upper jaw." Naturally he lost.

The Mouth Test for Cattle.-The "toothing" of cattle on the range is the means of settling many a wager as to the age of an animal. It is not by any means a very satisfactory method because of so many variations in the age at which different animals shed their milk teeth and get the permanent ones. This is due to accidents,
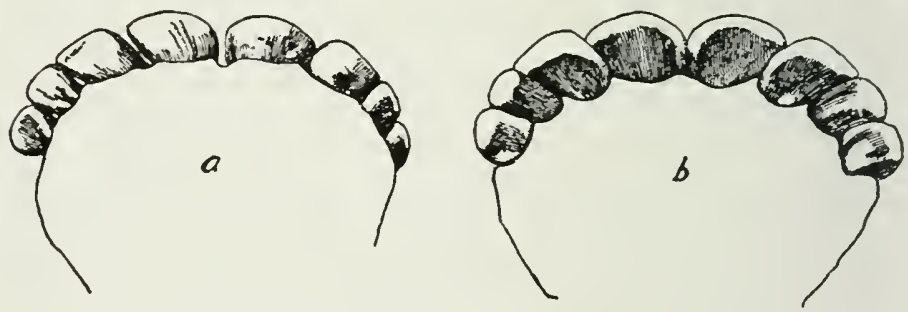

Incisors of the calf-a, external face; $b$, internal face.

feed, breeding and many other causes. On a range where cattle eat browse they break off their calf teeth mucl; earlier than otherwise.

The following very liberal rules were adopted by the management of the International Live Stock Exposition, 


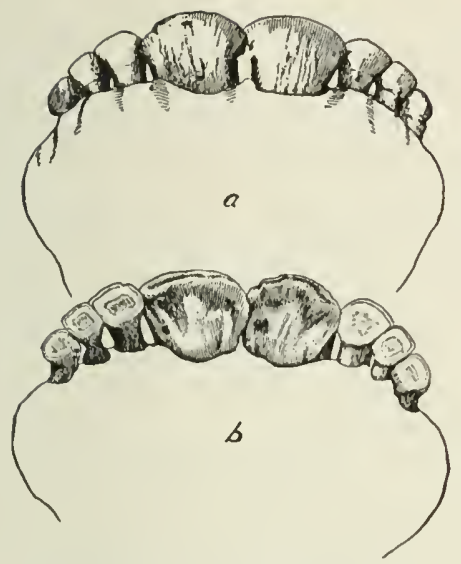

Teeth of the cow at two years, a, ex. ternal face; $b$, internal face.

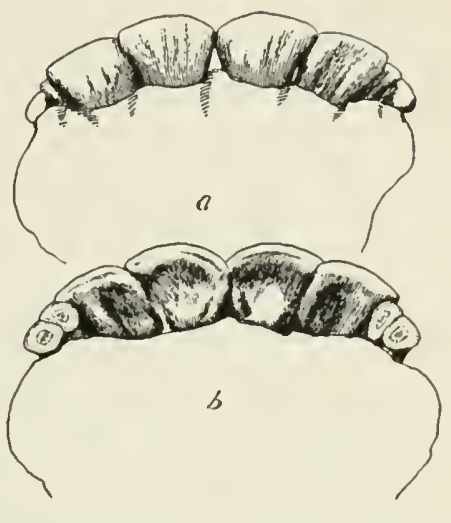

Teeth of the cow at two years, nine months. a, external face; b, internal face.

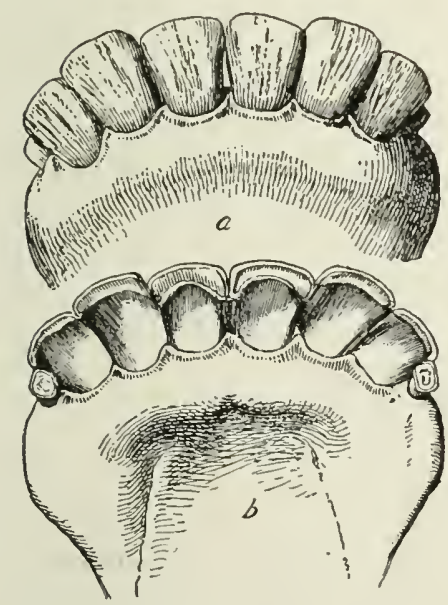

Teeth of the cow at three years, six months. a, external face; b, internal face.
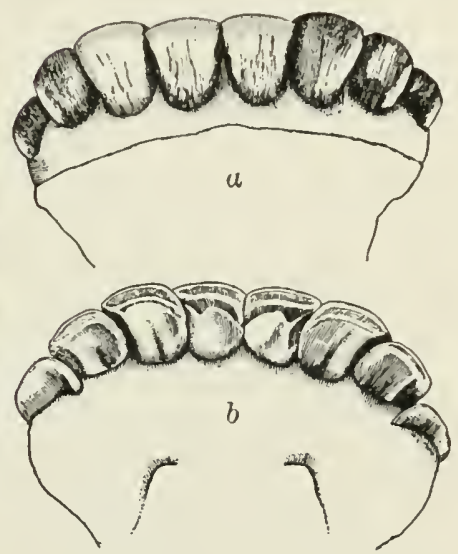

Teeth of the cow at four years. 
Chicago, in 1904, not as representing absolute accuracy, but in the direction of giving the feeder the benefit of the doubt:

Twelve Months: An animal of this age shall have all of its milk (calf) incisor teeth in place.

Fifteen Months: At this age the center pair of incisor milk teeth may be replaced by center pair of permanent incisors (pinchers), the latter teeth being through the gums but not yet in wear.

Eighteen Months: The middle pair of permanent incisors at this age should be fully up and in wear, but next pair (first intermediate) not yet cut through gums.

Twenty-four Months: The mouth at this age will show two middle permanent (broad) incisors fully up and in wear, and next pair (first intermediate) well up but not in wear.

Thirty Months: The mouth at this age may show six broad permanent incisors, the middle and first intermediate pairs fully up and in wear and the next pair (second intermediate) well up but not in wear.

Thirty-six Months: Three pairs of broad teeth should be fully up and in wear and the corner milk teeth may be shed or shedding, with the corner permanent teeth just appearing through gums.

Thirty-nine Months: Three pairs of broad teeth will be fully up and in wear and corner teeth (incisors) through gums but not in wear.

Horn Buttons.-An unfailing method of determining between two and three-year-old steers is by means of the little button on the tip of the horns. This button or rough place on the end of a two-year-old's horns is simply the shedding off of the outside shell, and so long 
as there is any of this roughness left as a button on the tips the animal is a two-year-old and generally the teeth will prove it. At full three the steer's horns are smooth and clean to the very tips.

Rings.-The rings on the base of a cow's horns are not altogether dependable as an evidence of her age. They do not come on her horns until she has dropped her first calf, which may vary considerably with certain animals. On an average the addition of three to the number of rings on the horns up to seven will be approximately correct, making the cow ten years old. After that, however, it is more an estimate than an accurate determination of the animal's age. Bulls and steers have no rings on their horns.

Age of Horses.-The horse has six incisors or front teeth and two tushes or canine teeth on each jaw, besides the grinders. At twelve months a horse has six colt teeth or incisors on each jaw which remain in use until the animal is about two and one-half years old. At that time the two center incisors are shed and the permanent teeth are coming in.

At from 2 to $2 \frac{1}{2}$ years the two central milk incisors are replaced by permanent incisors and these are up and in wear at 3 .

At from 3 to $3 \frac{1}{2}$ years the two lateral milk incisors are replaced by permanent incisors and these are up and in wear at 4.

At 4 to $4 \frac{1}{2}$ the corner incisors are replaced and are up and in wear at 5. The tushes come in at the same time.

At 6 the "cups" or marks begin to disappear from the central permanent incisors. 

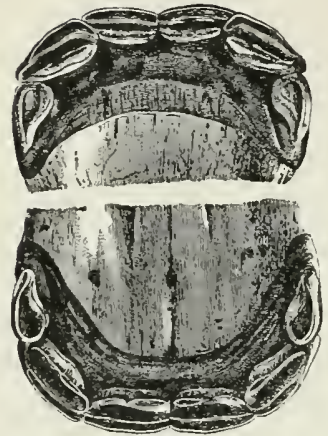

Teeth of the horse at one year.
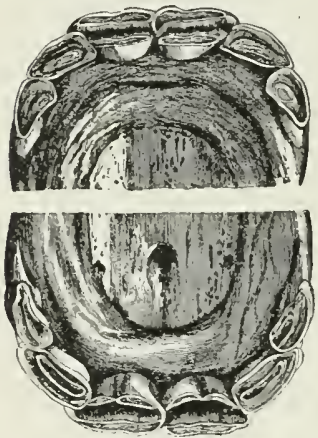

Teeth of the horse at three years off.
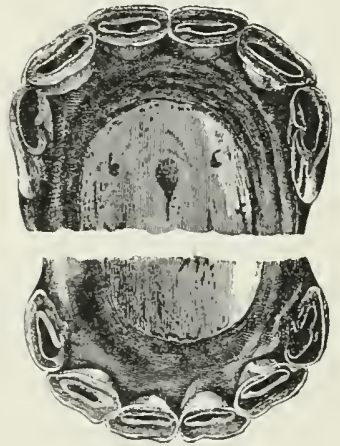

Teeth of the horse at six years.
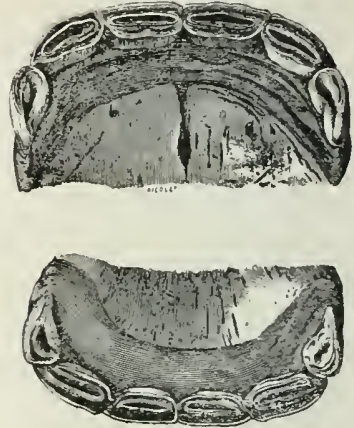

Teeth of the horse at two years.
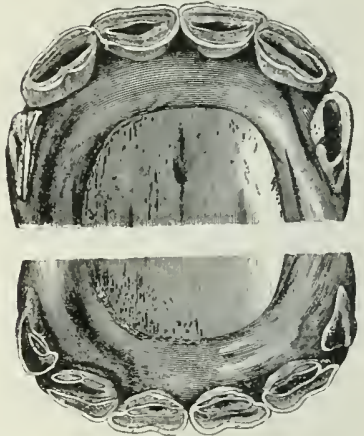

Teeth of the horse at four years off.
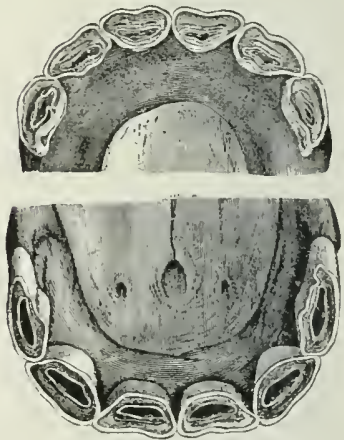

Teeth of the horse at eight years. 
At 7 the "cups" or marks begin to disappear from the lateral permanent incisors.

At 8 the "cups" or marks begin to disappear from the corner permanent incisors.

The wearing-away process is shown more particularly in the "cups" or dark, oval rings in the teetl. 'This at first extends clear across the face of the tooth, but as the tooth wears down the ring draws in until finally it almost disappears. It is as if there were a small darkcolored inverted cone in the tontls. As this cone wears down the dianeter of the base gradually lessens until it becomes a mere dot or point.

The feed given a lorse has much to do with the wearing away of the teeth. There is a tremendous difference in this respect between horses raised in an alfalfa country where very little or no corn is fed and those raised in a corn-growing region, the latter showing far more wear on the tecth. In Arizona we used to think that as between two horses, one born and raised in the mountains and the other in the sandhill ranges, the latter showed a great deal more wear on his teeth, due to the grinding effects of the sand picked up in grazing.

However, after eight or nine years the determination of the age of a horse is more or less a matter of guesswork, as the teeth furnish no sure evidence of the animal's age.

The supra-orbits or soft places above a horse's eyes are one test most commonly used. In the young horse the skin here is nearly level with the rest of the forehead. With advancing age it begins to hollow ont until in a horse over ten or twelve the cavities are very deep. Also the ears offer another means, as with age they begin 

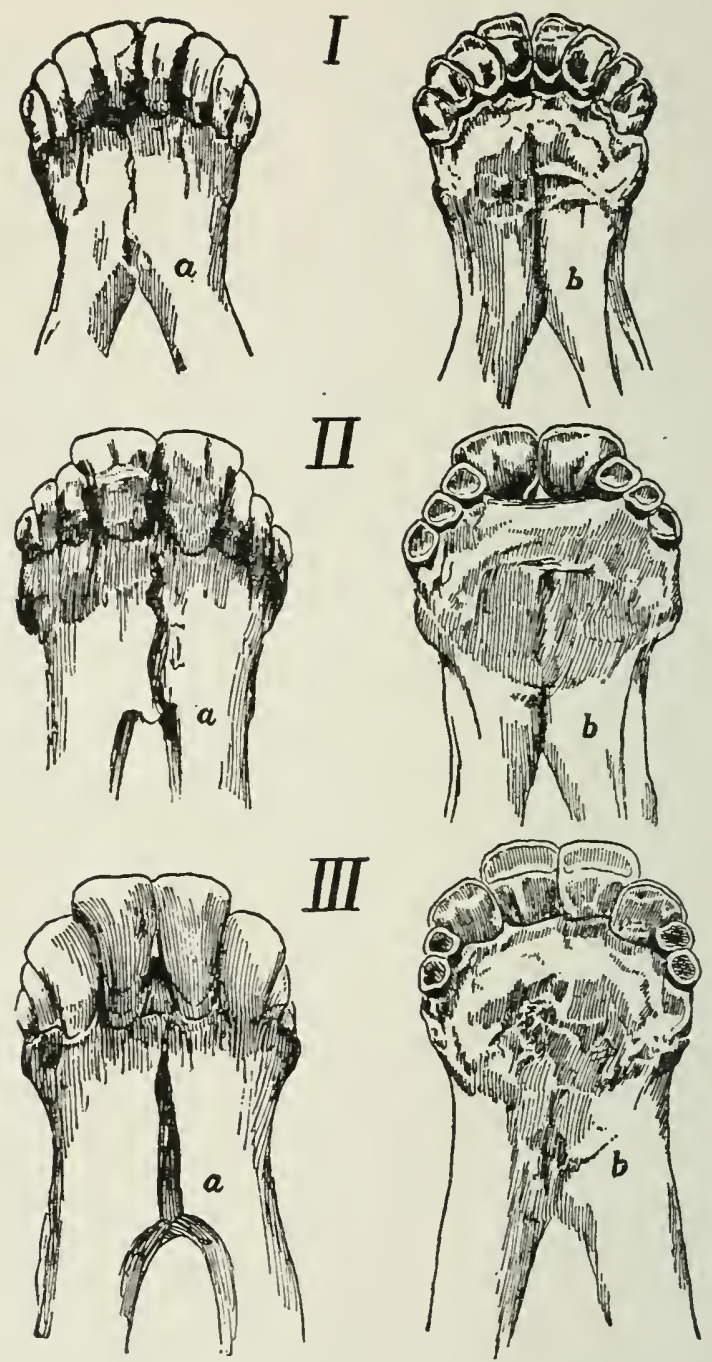

Teeth of the Sheep-I, at one year; II, at eighteen months; III, at two years, three months, a, external face; b, internal face. 

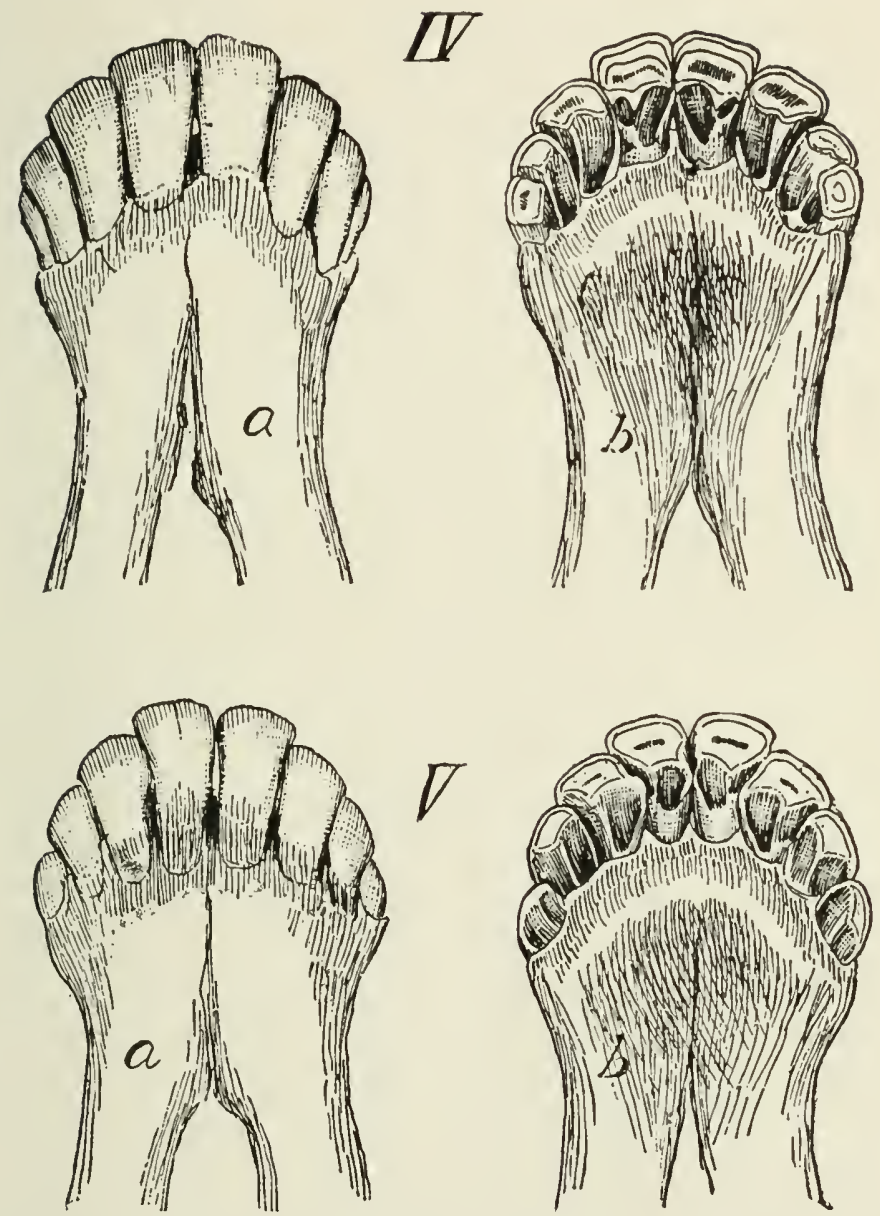

Teeth of the Sheep-IV, at three years; V, at four years, a, external face; b, internal face. 
to draw nearer together and stick straight up and seem to have less flexibility either to use or to the touch. The face also about the eyes and on the forehead will show gray hairs, much as a person begins to get gray on the temples.

To the experienced horseman the whole face gives an indication of age but there is no rule that will aid the ordinary investigator to take advantage of these points. It is a matter of experience, judgment and in most cases pure intuition.

Age of Sheep.-Like all ruminants, sheep have no upper front teeth.

The lamb has six small white milk teeth.

Between twelve and fifteen months, the center pair drop out and two permanent incisors come in.

At twenty to twenty-four, the next two permanent incisors come in.

At thirty to thirty-six, two more permanent incisors appear.

At forty and over the last permanent pair of incisors -the corner pair-come in and the mouth is full.

This gives the sheep eight incisors, two more than the cow or horse.

The permanent teeth of the sheep can easily be distinguished, for they are darker in color and twice the size of the milk teeth. After four years, the only way to ascertain the age of a sheep by the teeth is from the wear on them.

Broken-mouthed ewes are those sheep some of whose teeth have been broken off in feeding. This condition generally begins to show from seven years and sheep thus injured should be legged out of a band and sold for fattening, as they will not do well on the range. 


\section{CHAPTER IX.}

\section{RANGE STOCK MANAGEMENT.}

The Government rules for handling stock on the National Forests require sheep and goat herds to be moved frequently and not bedded down in one place more than six successive nights. Nor is a lazy herder allowed to dodge the spirit of the rule by moving off the bed ground for a single night and then going back to it again. The wisdom of this regulation is so apparent that it is hard to see why there can be any possible objection to it.

Objections to Repeated Use of Bed Ground.-The wear and tear on a range when sheep come into the same bed ground night after night is great, and also the sheep undoubtedly suffer from having to travel back and forth every day across a stretch of range which has been picked over again and again until the very grass roots are torn out. Many losses from poisoning result from this cause, as the sheep leave the bed ground in the morning hungry and eat injurious weeds and forage plants which they would not touch if there were anything else available.

Progressive sheepmen who own or lease large areas of grazing lands will not allow a herder to bed his sheep twice successively on the same spot, but have him seek a new location each night and if possible not less than 
half a mile from the one on which he last camped. This gives the range an opportunity to freshen up, and adds greatly to its grazing value.

Salting Stock.-Cattle, horses, sheep and goats all crave salt. Stockmen estimate that on an average a cow should consume ten pounds per year, a horse about six and a sheep two or three. They will of course use more on some ranges than on others, depending on the natural "licks" or alkali spots found all over the western country. In many places like the Salt River Valley in Arizona and along the Rio Grande in New Mexico, the alkali or salt in the water satisfies their cravings so well that animals will not pay any attention to salt when placed where they can reach it.

But in summer, when the animals are in the high mountains where they get green feed and fresh water, they seem to require a great deal of salt. As a general thing they will consume about twice as much salt during the months when feed is green as they will after it has been frosted and loses its freshness. Stock, especially sheep, that are using the desert ranges in the winter where their chief feed is browse need plenty of salt. Without it digestion seems to be difficult and they do not seem to do so well as where they can obtain all the salt they want.

Salt and Sulphur.-Plenty of salt also tends to keep down the worms in stock, especially where a 2 per cent weight of flowers of sulphur is mixed with it. This is always a good thing to do every spring. The sulphur should be thoroughly mixed with the salt and with two pounds of sulphur to 100 pounds of salt the animals will eat it with relish.

Kind of Salt to Use.-For salting cattle on the range 
where it must be placed and left for the animals to use at their pleasure, rock salt is probably the most economical and satisfactory, for it does not melt and wash away with the rains as badly as fine salt. Again, salt-hungry cattle and sheep can easily be killed by dumping out a few sacks of fine salt and letting them have all they want of it.

On the Little Colorado River in northern Arizona a herd of 1,800 salt-hungry sheep fresh from the mountains was turned onto a wagonload of fine lake salt which had been dumped from the freighter's wagon in a long white line. Within a few hours half the band was dead and many more were so sick they could not be moved for some time.

On another occasion, two wagonloads of the same kind of salt were dumped in a great heap on a favorite cattle-salting ground high up in the mountains with the intention of burying it in trenches or ditches so as to form licks. The round-up came along that day and threw about 1,000 cattle onto the salting ground. The cattle crowded about the heaps of salt and before anv cne noticed what was going on fifty were dead and man more very sick. This cannot happen where rock salt i; used, because the animals can not get enough at one time to injure them. On the other hand, when salthungry, stock will eat the fine salt in great quantities, chewing it down as they would oats.

Effect of Excessive Salt.-The effect of too much salt seems to be to dry up the juices of the stomach, "burn them out," as the stockmen say. The entire stomach seems to be as dry and baked as if the animal had been dead for months.

Fine salt is somewhat cheaper than rock salt, espe- 
cially in those parts of the West where, as in New Mexico, the great salt lakes furnish an inexhaustible supply of coarse-grained salt. There it may be had for the hauling, and the cost of course depends entirely on the distance to be hauled.

The Salt Lakes.-These salt lakes are peculiar places, resembling large fresh-water ponds among the hills. The water is seldom more than a foot or two deep, and beneath it lies the salt. To obtain it they simply drive the wagon out into the water and shovel in the salt, which lies loose and is as easily dug as so much fine gravel. A hundred wagons may load at one such lake in a single day and within a short time the hole made has filled up again. Some of these lakes have been so used for 300 years and today the surface is apparently at the same level as when the first white men visited them back in 1545 .

In feeding rock salt all that is necessary is to dump out the pieces and let the animals lick it as they please. With fine salt some sort of trough or receptacle must be provided in which to place it, and if the animals are salt-hungry but a small amount should be placed in reach at one time. One objection to rock salt is that it takes cattle a long time to get enough of it. Another is that through the licking process they get sore tongues. After feeding rock salt for twenty-five years and watching carefully for any evidences of this among range cattle at the local slaughter houses, I have yet to see the first case of sore-tongue due to this cause.

Making a Salt Lick.-The plan of digging long trenches and putting salt in them, mixing it with a little 
dirt, makes a very good lick and the salt cements together into a solid block.

Many stockmen like to salt their cattle in their own corrals, so as to teach them where home is. Others like to feed it to them a little at a time on the ranges, keeping them just salt-hungry enough to make them eager for it. Thus they learn to come up for salt every time they hear the call or even the rattle of the wagon containing the salt.

Being under herd, sheep can be salted often and the fine salt is better for them, as to salt 2,000 sheep entirely with rock salt would require too many separate picces.

Salt-Hungry Cattle Raid Camps.-In the mountains where range cattle are plentiful and generally salthungry, one must be careful about leaving a camp open, as they will smell the salt and fairly eat the camp up in their search for it. Salt, sugar, flour, dishrags and everything else chewable will find its way down their throats, and what they don't eat they will spoil. If there is anything more discouraging to the camper or absolutely hopeless in the completeness of the ruin than a camp raided by a bunch of salt-hungry cows I have never seen it. I once opened the door of a cabin just as a cow went out of a single sash window at the other end. She had probably found the door open and stepped in to look for salt. A gust of wind closed it, or possibly she pushed it shut herself in rummaging about the little room, and was a prisoner. The interior of that cabin was a wreck.

Another time a bull hunting for salt worked through the flap into a tent which had a small opening at the far end. The boy who occupied the tent started to enter the 
flap and the bull made a dash for the other end. He forced his head and fore feet through the small opening and set off down the flat carrying the tent with him, torn from its moorings as if struck by a cyclone. Eventually he tripped over it, fell down in a heap, and in his struggles tore the tent to ribbons.

Source of Friction.-The salting of stock on the open ranges is an everlasting source of friction among stockmen using the range. Each man waits for his neighbor to salt. The more enterprising men salt liberally and their shiftless, selfish neighbors, knowing full well that their cattle can and will hunt the salt ground, no matter how far it may be, sit back and profit by the other man's liberality.

The most successful plan is to have the salting done by some man hired to handle the whole process and each man stand his pro-rata of the cost, based upon the assessed number of cattle each has on the range.

This of course can only be accomplished through cooperation, in many instances of which a few men do it all.

Salt is money well invested. It makes the animals more content on the ranges, keeps them on their own range instead of wandering all over the country looking for salt, gentles them, teaches them to know the presence of man, undoubtedly does much to assist in digesting certain feeds, and to a certain extent keeps down the worms which are found in the stomach of almost every four-footed domestic animal.

Experiments With Salt.-The report of the Bureau of Animal Industry for 1902 gives the results of some experiments, which are very instructive, on the value of salt for animals. In France two selected bands of 
sheep were taken, each of as near the same weight and breeding as was possible, weighed carefully before the experiment and placed in separate pens. Here they were fed the same feeds and handled alike. One band was fed no salt, while the other was fed three-fourths of an ounce daily with the other feed.

When the experiment was closed the sheep that had been fed salt weighed $53 / 4$ pounds more and sheared $13 / 4$ pounds of wool each more than the band which received no salt. The wool of the salted sheep was also of more excellent quality and better fibre than that of the others.

Bulls on the Range.-The question of the number of bulls needed on the ranges is a perplexing one and, like salting, is the cause of a great deal of hard feeling among stockmen. Most of the western range states have laws calling for at least one good grade bull for every twentyfive breeding cows, but I am quite certain that the court records of every range state may be searched in vain for a single case where it has been enforced.

Number of Bulls to Cows.-Without plenty of bulls, there can certainly be no hope for reasonable increase. In the large pasture outfits in Texas and New Mexico where, as a rule, the bulls are kept away from the cows part of each year, not less than five good active young bulls are considered enough for 100 cows. Nor is this a bull too many on the open ranges where the cattle scatter out into small bunches and especially in a rough country where the bulls do not as a general thing follow the cows.

Age of Usefulness.-Bulls seem to lose their vigor early in life, and a bull ten years old is in the judgment of most stockmen past his prime. From three to seven 
is the age at which they are at their best. After that the sooner they are sold the better, for they get heavy, lazy and sullen, keeping by themselves, hanging about the water holes and not attending to business as they should. Probably many readers will recall instances where a bull has been used for many years after he passed the ten-year mark, like the famous Sir Bredwell for instance, but these animals were kept up, fed well and not allowed to exhaust their vitality, as bulls will on the range. Moreover they had the cows brought to them for service instead of having to hunt them up on the range.

Many stockmen believe that an old bull begets more male than female calves, but careful investigation has not proved this to be the case. The same is true of the oft-repeated assertion that an old bull is not so sure a getter as a younger animal.

Dehorning Cattle.-Bulls should not be dehorned so close as to make them niuleys, as they need their horns as a means of defense isdinst steers or stags. But certainly every bull turned out on the range and allowed to run loose with the other cattle should have at least four inches of the sharp points taken off his horns. This is easily done by either throwing or snubbing them up to a strong pnst or fence and taking the points off with a pair of $d$ wrning clippers or an ordinary neat saw.

Many a good bull has busı k11led or injured so as to be unfit for use all the rest of the season by having a pair of stiletto-like horns driven into him by some fighter among the other bulls. With the points gone but the stubs still there they can fight and protect themselves but can not do much harm to one another. 
Dehorning the Calves.-Many stockmen dehorn their calves as they are branded, using a small dehorning tool made especially for the purpose. When the calf is less than five weeks old the little button of the horn can be taken off very readily by clipping the hair around it and then rubbing it with a stick of caustic potash. Ordinary concentrated lye will also cut then ont. Care must be taken not to get the caustic or lye into the eye of the animal. As few range calves can be handled at this early age, the dehorning tonl is the most satisfactory method of ridling the aninal of its horns.

Value of Dehorned Cattle.--1)ehorned cattle on the markets bring from $\$ 1$ to $\$ 3$ per head more than the same grade of horned animals, so that the process pays the raiser of the animal very well. Besides this, they ship better, more will go in a car and easier, are free from the fearful slashes and cuts made by the horns of aggressive animals when bunched together, and feed together more like a lot of sheep than anything else.

Naturally the best way to get rid of horns is to breed them off, but until that time comes dehorning when the animal is small is the next best means of meeting the demand for the hormless animal.

Marking Cattle.-Several years ago considerable matter appeared in the western stock papers about a branding fluid used in Australia. It was said to be quite as satisfactory as a hot iron for placing a brand on an animal, and much less painful and did not injure the hide.

The fluid was composed of several acids and corrosive ingredients and when used on a single animal where there was plenty of time to do it carefully, would kill the hair and leave a brand on the hide 
which was fairly plain. The idea was either to paint it on with a brush or daub it on with a wooden brand similar to those used by the sheepmen in "paint marking."

In practical use, with a corral full of calves to be branded, it was a failure. The stuff, if put on thick enough to penetrate the hair, ran all over the animal and made a great blotch. It was easily kicked over by a struggling calf and, worst of all, in the rush and hurry

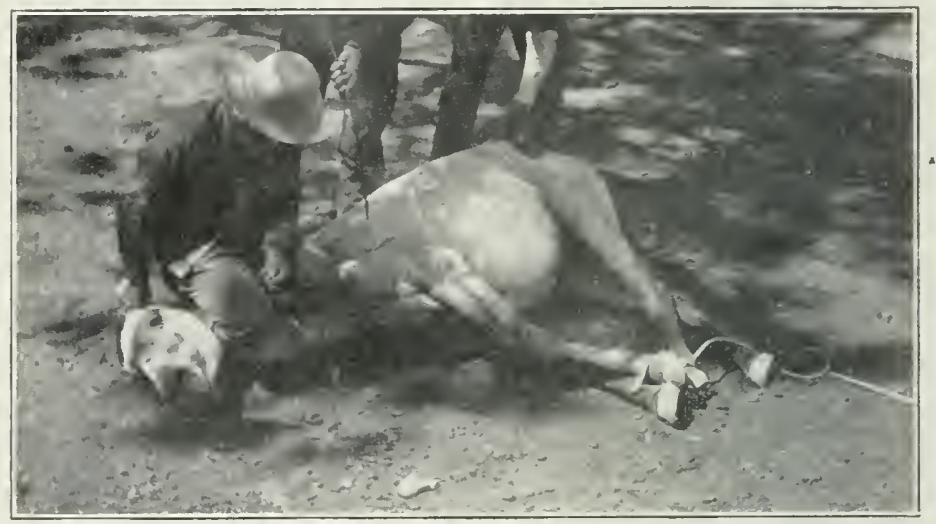

"Hog Tied"-A Horse Tied Down for Branding or Doctoring.

of branding time, it got into the men's eyes and made much trouble. Then too the calves after being so branded would crowd against one another in the pen and smear the fluid all over themselies.

No one ever tried it a second time and the hot iron is still the most satisfactory method of branding range ?nimals.

Ear and Lip Tattoo.-There are several methods of narking animals in the ear by means of a punch in 
which the outline of the brand or number is made by a lot of needle points similar to the punch used by railroad agents to mark tickets when sold. These marking punches are filled with a preparation of India ink which outlines the brand in an indelible manner. These of course can only be used with gentle animals and are not intended for range use. Recently the Federal Government has considered this method for marking cavalry and artillery horses and the Government mules. The mark is placed on the animal's lip and will be much better as a means of identification than the hoof number which must be frequently renewed.

Ear Marking.--Each owner has some ear mark recorded as a part and portion of his brand. On the round-ups and for a great part of the year the ear mark is the only means of identification, unless an animal is caught and held for examination. This is of course due to the long hair in winter, and until the animals have shed off in the spring and the hair is short the brand is not easily read. The mark is readily put in with a sharp knife and causes the animal but little pain. Many range states have laws regulating the amount of the ear which may be taken off, the thought being to protect the honest man by refusing the use of a mark that like a "grub," for instance, simply cuts off the whole ear and leaves nothing of the mark that may have once been there.

Castrating.-With the operation of marking goes the one of castrating the animal. This is a rough and ready piece of surgery, but seldom results in an injury to the animal. The old Californians who raised the animal as much for the hide as for the meat never trimmed their bulls, believing that the hide was heavier and 
the beef product greater. With them it was a question of quantity and not quality.

Usual Method.-A calf is never too small to be castrated. The usual method is to clip off a small piece of the end of the scrotum or bag and squeeze out the testicles, and either pull them out with main force until the cord breaks off itself or else far enough so as to cut it off with a knife. Some men advocate cutting a small hole out of which the testicle can be pulled, as is done in castrating a colt, but this frequently causes trouble, owing to the closing up of the small opening and a formation of pus inside, which often results in the animal's death.

Keeping Tab on Sex.-In the old days of heavy brandings where the owners kept track of the sex, it was the usual custom to keep the end of the scrotum for a tally on the bull calves, and a piece of the ear taken off for the heifers. As a general thing, however, taking the usual run of brandings year after year, the difference between the sexes is so small as to amount practically to nothing. Sometimes in the spring roundups the heifer calves will run away ahead of the bulls, but on the fall work the balance swings back and on the final footings the proportion of each is close to onehalf.

Ear Marks.-Cattle, sheep and hogs are earmarked, but horses are seldom so disfigured, although I have seen many car-marked western range horses, generally mares, especially in the days when only the geldings were sold or used. Following are some of the prominent marks used. The combinations which can be made are almost innumerable: 

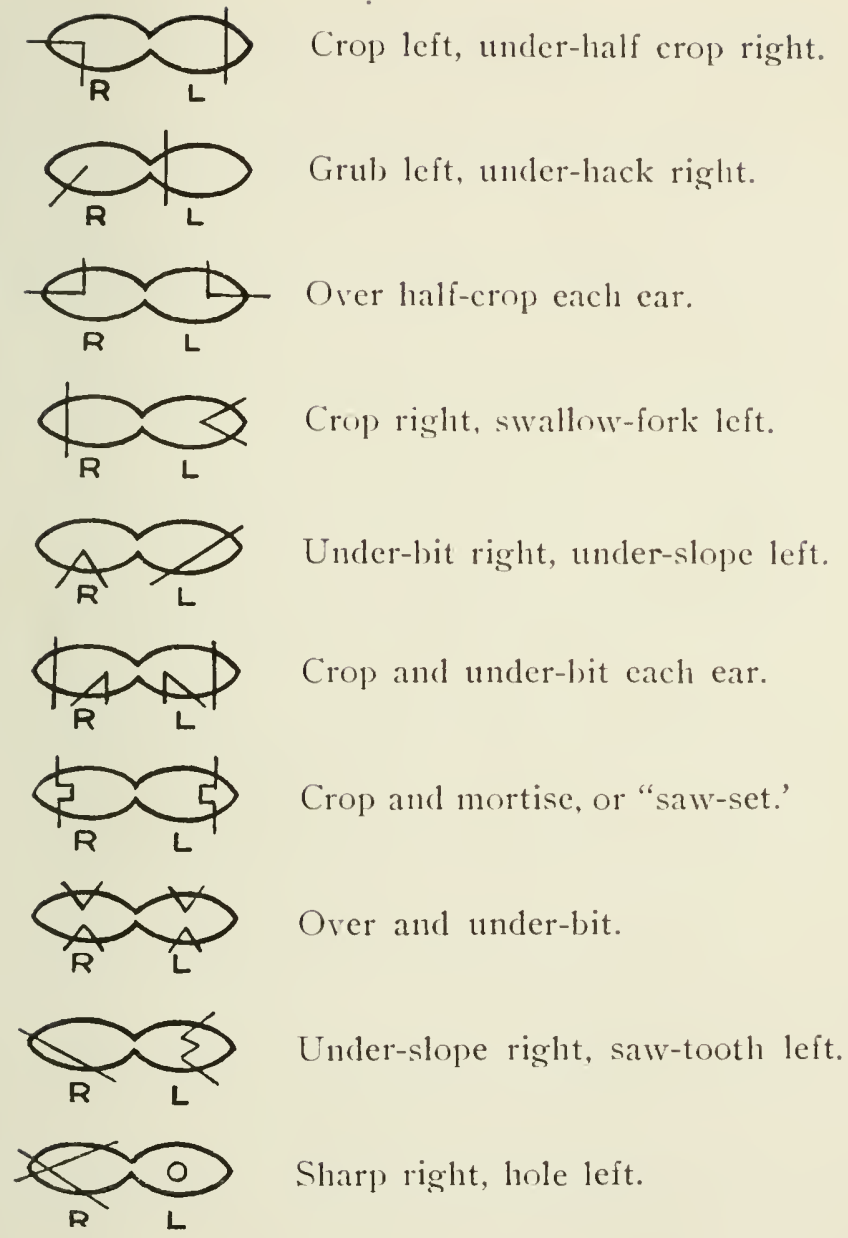

The "jingle bob," as explained on page 382, is made by cutting into the top of the ear, close to the head, and 
just deeply enough to break the back of the ear and allow it to hang down alongside the animal's head. It is a most unprepossessing mark indeed.

Brand Books.-Following are pages taken from the Brand Books of different live stock associations:

Cimarron range

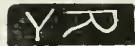

Angwhere Whole ear

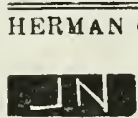

East side Cow Creek

\section{Ridgway}

Anywhere Whole ear

Horses same unywhere

\begin{tabular}{l} 
A. R. CALKINS, \\
Bald Hills range \\
$\begin{array}{l}\text { right eide underbit left split } \\
\text { right ear }\end{array}$ \\
\hline$\overline{\text { J. DAVIS. }} \begin{array}{l}\text { Big Cimarron range } \\
\text { left side or anywere on ani- } \\
\text { mal over slope each ear Hor- }\end{array}$
\end{tabular}
seasame eithor shoulder

E. M. DAWES.
Horsefly range
right shoulder

Wm. A. DOAK

Mcntrose

- Tabeguache range

4 lett side, crop both oars

FRANK DONLAVY.
Cimarron range
$\mathrm{DON}$ lefthip Also

Mrs. SARAH E. and Mrs. AGNES DAIVSON Montrose.

Cimarroa range

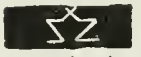

and

both ears horse brand same and

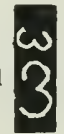

From the Brand Book of a Colorado Cattle Association. 


\section{L. SCHOONOVER-}

Cattle Branded

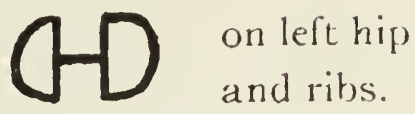

Upper bit in cach ear.

Horses Branded 2 on left shoulder.

J. P. WHITE-

Cattle Branded

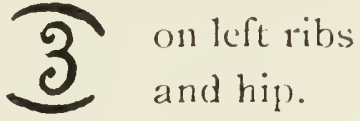

M. C. DURFEE-

Cattle Branded

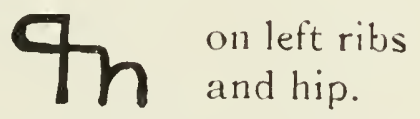

Horses same brand on left shoulder.

Some cattle branded
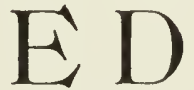

on left ribs.

Ear mark for cattle, hole in cach ear, split out.

J. F. ANDRESS-

Cattle branded

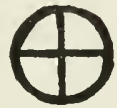

on right hip.

T. M. PARKS-

Cattle branded

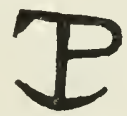

on right hip and ribs.

Horses same brand on right shoulder Ear mark for cattle, both ears undercropped. Sample Page From a Western Live Stoc's Association Ira..d Icos. 


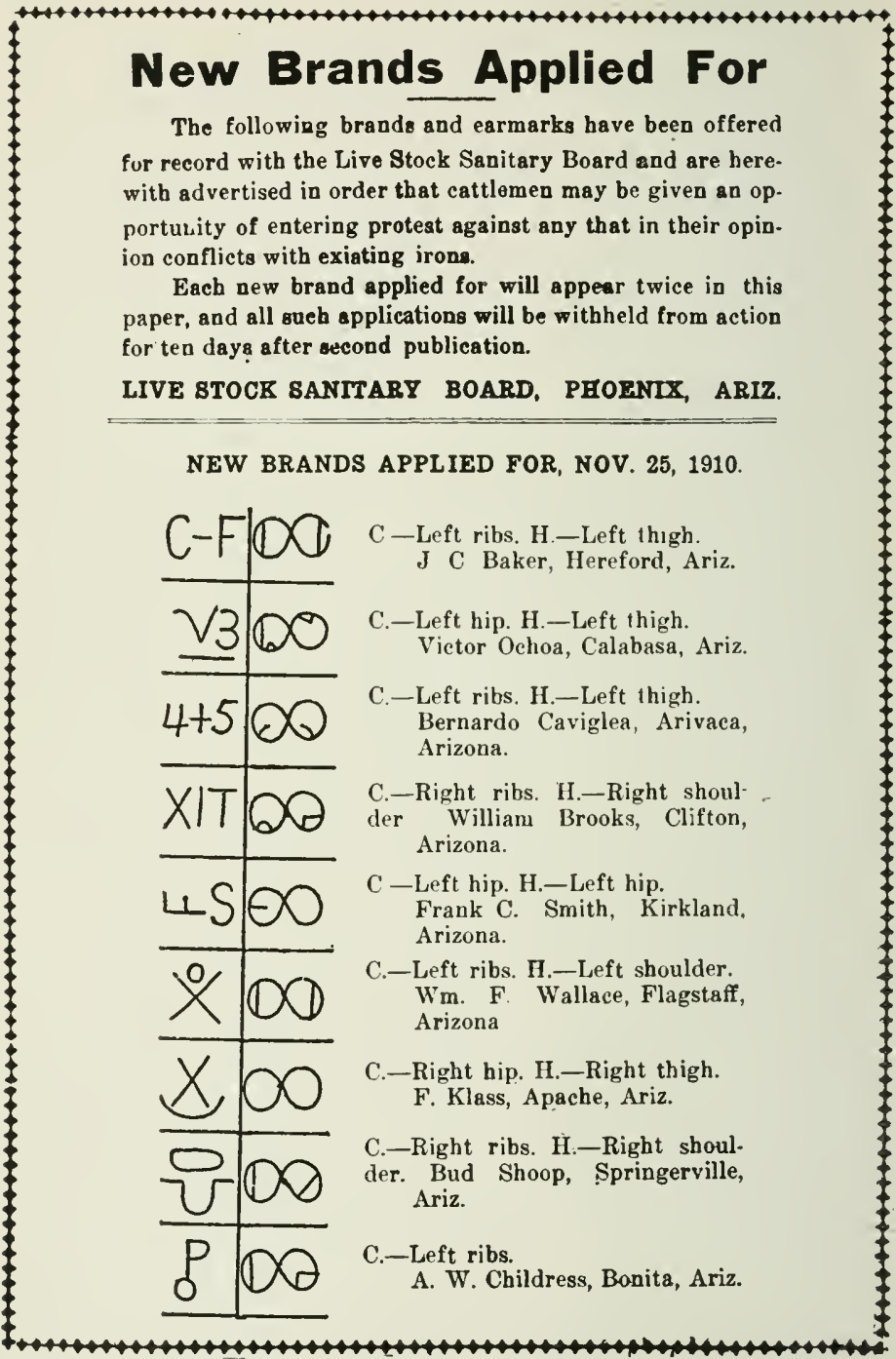

Sample Page of New Brands Advertised in an Arizona Paper, Showing the Method Used to Avoid Issuing Conflicting Brands, 


\begin{tabular}{|c|c|c|c|c|c|c|c|}
\hline$\rightarrow A B$ & & $\begin{array}{l}\text { A. Moxoleon, } \\
\text { Rocks pord. } \\
\text { otero co. }\end{array}$ & & & $\begin{array}{l}\text { 0oorgo oundereon, st } \\
\text { colibran. } \\
\text { Woas co. }\end{array}$ & & $\begin{array}{l}\text { Mocinnio. } \\
\text { Motote. } \\
\text { Conejoo co. }\end{array}$ \\
\hline 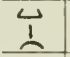 & & $\begin{array}{l}\text { Haloy Gould, } \\
\text { ol beoh, Yebr. } \\
\text { Rango Rout Co.Col. }\end{array}$ & & & 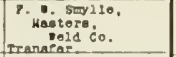 & & $\begin{array}{l}\text { Wro.Dal ay Durning- } \\
\text { ton, oloote. } \\
\text { Boglo Co. }\end{array}$ \\
\hline : & & $\begin{array}{l}\text { m, TKolton, } \\
\text { Quiney Bl6g. Den- } \\
\text { ver: Rargo, Tolior Co. }\end{array}$ & & & $\begin{array}{l}\text { Wa,c.p. Foodrufe. } \\
\text { olotho, } \\
\text { montroes co. }\end{array}$ & 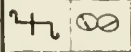 & $\begin{array}{l}\text { ADblo Paone vuagni- } \\
\text { elux, glonerro. } \\
\text { Leriant Co. }\end{array}$ \\
\hline & & 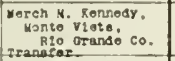 & & Do & $\begin{array}{l}\text { Samuel R. cone. } \\
\text { Nucla, } \\
\text { Nontroas co. }\end{array}$ & & 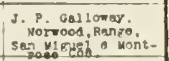 \\
\hline & & $\begin{array}{l}\text { a Poidolman, } \\
\text { Fiaglor. } \\
\text { Rit Carson co }\end{array}$ & & 50 & $\begin{array}{l}\text { Kaloy a could, } \\
\text { Jol baoh, Nobr. } \\
\text { Rango, Roui: Co.col } \\
\text { Transear. }\end{array}$ & & $\begin{array}{l}\text { E. A. vil toholl. } \\
\text { Parlita. } \\
\text { Gunison co. }\end{array}$ \\
\hline & & $\begin{array}{l}\text { Eenar A. Treot } \\
\text { Aralo. co. } \\
\text { Nold co. }\end{array}$ & & & $\begin{array}{l}\text { ruataos A. Paroond } \\
\text { Parker, } \\
\text { Dougias Co. }\end{array}$ & & $\begin{array}{l}\text { Tea Hamsom, } \\
\text { gawt, } \\
\text { Told co. }\end{array}$ \\
\hline & & $\begin{array}{l}\text { C J. Cozbe. } \\
\text { stoambot SDge . } \\
\text { Routt Co. }\end{array}$ & & & $\begin{array}{c}\text { Thoodore Lang, } \\
\text { pt. Coliling; } \\
\text { Larloer co }\end{array}$ & 6 & $\begin{array}{l}\text { Chea. Huber, } \\
\text { Koaxer, } \\
\text { R10 Bs anco Co. }\end{array}$ \\
\hline & & $\begin{array}{l}\text { gabino s, Torros. } \\
\text { trinidad, } \\
\text { Las Animes co. }\end{array}$ & & & $\begin{array}{l}\text { H. Eloholtz.jr. } \\
\text { gateo Park, } \\
\text { Larteor co. }\end{array}$ & D & 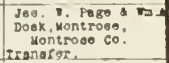 \\
\hline & & 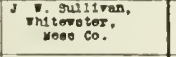 & & & $\begin{array}{l}\text { aorge utekaleon, } \\
\text { snydor. } \\
\text { Morgon co }\end{array}$ & & $\begin{array}{l}\text { samual kabaxor, } \\
\text { zilzabath, } \\
\text { E2bert co. }\end{array}$ \\
\hline u & & $\begin{array}{l}\text { D. Lorimos. } \\
\text { Motohxieg. } \\
\text { Dolta co. }\end{array}$ & & & $\begin{array}{l}\text { Alez. Calnown, } \\
\text { Toilurido. } \\
\text { tranergan wisiel co. }\end{array}$ & & 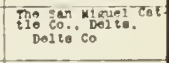 \\
\hline & & $\begin{array}{l}\text { M1ko sebastieno } \\
\text { Trinidad, } \\
\text { Los Aninas co } \\
\text { R.D.2. }\end{array}$ & & & $\begin{array}{l}\text { C. J. Jooobo, } \\
\text { ster } 11 \mathrm{ng} \text {. Loganco } \\
\text { tranaros. }\end{array}$ & 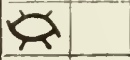 & $\begin{array}{l}\text { 1t S. Ellos. } \\
\text { Dison, wo. Range. } \\
\text { Route Co. Colo. }\end{array}$ \\
\hline & & $\begin{array}{l}\text { E. rrost, } \\
\text { storilng, } \\
\text { Logan co }\end{array}$ & & & $\begin{array}{l}\text { Storo poet, } \\
\text { sulphur, } \\
\text { Alo gianoo co. }\end{array}$ & & $\begin{array}{l}\text { "J. Dintor. } \\
\text { micla, } \\
\text { Hontrose co. }\end{array}$ \\
\hline & & $\begin{array}{l}\text { Lowle L. Fi16on, } \\
\text { Yamps, } \\
\text { Routt co. }\end{array}$ & & & $\begin{array}{l}\text { C. Loreon, } \\
\text { P1ooanoo, } \\
\text { A10 glanoo Co. }\end{array}$ & & $\begin{array}{l}\text { J. P. 0allogos, } \\
\text { San Lute, } \\
\text { Cootilis, Co. }\end{array}$ \\
\hline & & $\begin{array}{l}\text { Do Fitt Dajo, } \\
\text { sloter, } \\
\text { Routt co. }\end{array}$ & & & $\begin{array}{l}\text { C Dit Royor, } \\
\text { ulison, } \\
\text { Lo PIEto co. }\end{array}$ & & \\
\hline & & $\begin{array}{l}\text { Pusolph Andoroon, } \\
\text { L117. } \\
\text { Rout co. }\end{array}$ & & & $\begin{array}{l}\text { T. Wooher. } \\
\text { canon city, } \\
\text { prosont co. } \\
\text { Traneear }\end{array}$ & & \\
\hline & & $\begin{array}{l}\text { John Jahngon, } \\
\text { Slater: } \\
\text { Rout: co. }\end{array}$ & & & $\begin{array}{l}\text { The arrownead bive- } \\
\text { Stoox co.' } \\
\text { swal 2ow', Puobloco } \\
\text { renacer. }\end{array}$ & & \\
\hline & & $\begin{array}{l}\text { Ernat gurkhardt, } \\
\text { S12ver Gliffo. } \\
\text { Cueter co. }\end{array}$ & & & $\begin{array}{l}\text { Bengamin il11 aro, } \\
\text { rormood. } \\
\text { San viguel co. }\end{array}$ & & \\
\hline & & 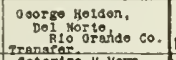 & & & 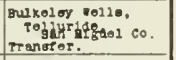 & & \\
\hline & & 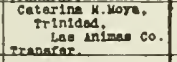 & & & $\begin{array}{l}\text { cyrue fall, } \\
\text { al amose, } \\
\text { Conojoo co. }\end{array}$ & & \\
\hline & $\mathbb{D}$ & $\begin{array}{l}\text { 1. J. Dantele. } \\
\text { PLoeanoo, } \\
810 \text { Blanoo co. } \\
\text { trantar. }\end{array}$ & & & $\begin{array}{l}\text { Pliar nonaragon. } \\
\text { Sen Lulo. } \\
\text { cootlila co. }\end{array}$ & & \\
\hline & & $\begin{array}{l}\text { renz } 1180, \\
\text { oranads; } \\
\text { Proworo Co. } \\
\end{array}$ & & & $\begin{array}{l}\text { s. C. Shopberd. } \\
\text { Hoskor. } \\
\text { R10 Bionoo co. }\end{array}$ & & \\
\hline & & 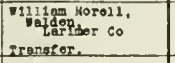 & & & $\begin{array}{l}\text { John Hogorman. } \\
\text { Rolyolo. } \\
\text { BMllipo Co. }\end{array}$ & & \\
\hline & & $\begin{array}{l}\text { Harrg 8. Leotor, } \\
\text { Clark, } \\
\text { Routt co. }\end{array}$ & & & $\begin{array}{c}\text { Chas, H. Hobber. } \\
\text { coioredo \$p6o.. } \\
\text { I1 Paso Co. }\end{array}$ & & - \\
\hline & & 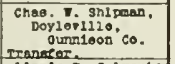 & & & $\begin{array}{l}\text { 8. R. Rpberto, } \\
\text { Puoblo, } \\
\text { Puoblo co. }\end{array}$ & & \\
\hline & & 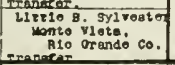 & & 0 & $\begin{array}{l}\text { Wary C. Ut tonoll, } \\
\text { Denvor: Rango, } \\
\text { Qrand Co. }\end{array}$ & & \\
\hline
\end{tabular}

A Page From the Colorado Brand Book.

The Colorado law allows the owner of a brand to place it anywhere on the animal he desires. 


\begin{tabular}{|c|c|c|c|c|c|}
\hline U & 10 & $\begin{array}{l}\text { Orbano Norf1r. } \\
\text { Cogoto. } \\
\text { I.R.C. L.E.R. }\end{array}$ & $R_{1}$ & & $\begin{array}{l}\text { A. Brian, } \\
\text { Portoles, } \\
\text { R.R.S.C. }\end{array}$ \\
\hline & & $\begin{array}{l}\text { MaS Pavlkner, } \\
\text { carlobad, } \\
\text { L.R.C. L.H.H. }\end{array}$ & & & $\begin{array}{l}\text { Rlosrdo Jrioete, } \\
\text { Chsperito. } \\
\text { L.R.C. I.S.H. }\end{array}$ \\
\hline & & 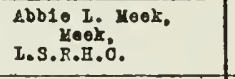 & & & $\begin{array}{c}\text { Doseta Romero. } \\
\text { Paraje. } \\
\text { L.H.H. }\end{array}$ \\
\hline & & $\begin{array}{l}\text { Cerep10 Loveto, } \\
\text { Nineral B1Il; } \\
\text { L.H.C. I.H.E. }\end{array}$ & $U R+$ & & $\begin{array}{l}\text { J: P. Lew18, } \\
\text { L.S.R.B.C. L.H.R. }\end{array}$ \\
\hline & & $\begin{array}{l}\text { J. D. Middleton, } \\
\text { Monument: } \\
\text { I.S.R.H.C. L.E.H. }\end{array}$ & & & $\begin{array}{l}\text { Milar Shell enb orger } \\
\text { Rod } 00 \text {. } \\
\text { L.5.B.C. \& H. }\end{array}$ \\
\hline & & $\begin{array}{l}\text { S. M. Yatoo, } \\
\text { Tularose, } \\
\text { L.S.R.H.C. }\end{array}$ & & & 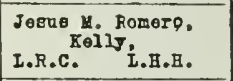 \\
\hline & & $\begin{array}{l}\text { Lattio J. Davia, } \\
\text { Lowor Ponasoa, } \\
\text { R.H.R.8.C. L.S.H.H }\end{array}$ & UR' & & $\begin{array}{l}\text { Tilliam Franki1n, } \\
\text { Feod, L.H.H. } \\
\text { L.B.C. }\end{array}$ \\
\hline & & $\begin{array}{l}\text { Platt \& Coloman. } \\
\text { elenoge, } \\
\text { L.R.C. I.H.H. }\end{array}$ & $U \frac{R}{O}$ & & $\begin{array}{l}\text { Inoz Beach, } \\
\text { Lonument, } \\
\text { L.B.P.C. }\end{array}$ \\
\hline$\overline{U I}$ & & $\begin{array}{l}\text { Platt \& Coleman, } \\
\text { EI Goga, } \\
\text { L.J.R.C. L.H.H. }\end{array}$ & UR 2 & & $\begin{array}{l}\text { Claranoe Cartis, } \\
\text { Inna, } \\
\text { L.s.R.E.C. L.H.H. }\end{array}$ \\
\hline & & $\begin{array}{l}\text { Hubbell \& Mose, } \\
\text { R Paro, 3axao } \\
\text { L.S.R.H.C. }\end{array}$ & UR2 & & $\begin{array}{l}\text { A. K. Fiar, } \\
\text { Dexter, } \\
\text { I.R.C. I.S.H. }\end{array}$ \\
\hline & & $\begin{array}{l}\text { Bar1d of Dright, } \\
\text { Lordsbarg. } \\
\text { I.s.R.R.C. }\end{array}$ & UR 5 & & $\begin{array}{l}\begin{array}{l}\text { A. L. Haynes, } \\
\text { Hopo, } \\
\text { L.P.C. L.S.H.H. }\end{array} \\
\end{array}$ \\
\hline & & $\begin{array}{l}\text { Pablo Dartado, } \\
\text { gan } \mu 1 \mathrm{ErOI} . \\
\text { I.H.O. I.H.H. }\end{array}$ & $U S$ & & $\begin{array}{l}\text { Kattio G. erews, } \\
\text { Hilisboro, } \\
\text { I.R.C. }\end{array}$ \\
\hline & & $\begin{array}{l}\text { J.D.F. E. E. Toorio } \\
\text { IBB V9gas, } \\
\text { I.H.C. }\end{array}$ & & & $\begin{array}{l}\text { Rafael Valdes, } \\
\text { Son Rafaei, } \\
\text { L.H.C. }\end{array}$ \\
\hline & & 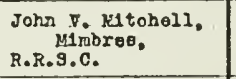 & (S) & & $\begin{array}{l}\text { Hro. L. E. Howard, } \\
\text { IIIfI, } \\
\text { L.R.C. I.H.H. }\end{array}$ \\
\hline & & $\begin{array}{l}\text { R. C. Paulkenar, } \\
\text { Corlabad, } \\
\text { R.R.C. R.R.F. }\end{array}$ & & & $\begin{array}{l}\text { Ch1oholn \& Graig, } \\
\text { Kagdal aos, } \\
\text { B.R.C. }\end{array}$ \\
\hline & & $\begin{array}{l}\text { Palton J. cox, } \\
\text { Laire Volleg, } \\
\text { B.R.C. I.H.I. }\end{array}$ & 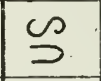 & & $\begin{array}{l}\text { Stanford \& Langford } \\
\text { Hagerman, } \\
\text { L.H.C. }\end{array}$ \\
\hline & $\theta \rightarrow$ & $\begin{array}{l}\text { E. u. Dolong, } \\
\text { Coore, } \\
\text { L.R.C. }\end{array}$ & US & & $\begin{array}{l}\text { Fhomse R. Yotkirk, } \\
\text { Yol Bom, } \\
\text { R.R.C. R.S.E. }\end{array}$ \\
\hline
\end{tabular}

A Page From the New Mexico Brand Book.

The first column shows the brand, the next the earmark. The initials below the owners' names refer to the brand location: L. R. C., left ribs cattle; L. H. H., left hip horses, etc. 


\begin{tabular}{|c|c|c|c|c|c|}
\hline BRANDS & $\begin{array}{c}\text { Possi } \\
\text { tion }\end{array}$ & NAME & P. O. ADDRESS & \multicolumn{2}{|c|}{ DATE OF RECORD } \\
\hline $4 !$ & 9 & Frank Randall & Woodsıde, Emery Co. & Jan. & 20,1903 \\
\hline & 9 & $\begin{array}{l}\text { H. C. Farrer and A. L. } \\
\text { Tomlinson }\end{array}$ & Green River, Emery Co. & June & 5,1903 \\
\hline & 10 & Elijah Maxfield & Loa, Wayne Co. & July & 17,1702 \\
\hline & 9 & Frank IIamblın & Kanab, Kane Co & Nov & 17,1902 \\
\hline & 8 & Edson McBeth & Payson, Utah Co. & Jan & $14, \mathrm{mO}_{3}$ \\
\hline & 14 & Matthew G. McMurtrie & Vırgın, Waslıngton Co. & June & 26,1902 \\
\hline & $\S 9$ & William M. Hafey & Westwater, Grand Co. & Nov. & 12,1902 \\
\hline & 15 & M. Slaymaker & Mapleton, Utah Co. & August & $.26,1903$ \\
\hline & 9 & P. G. \& Adam Burt & Spanıslı Fork, Utah Co. & March & 3,1903 \\
\hline & 15 & W. S. Twombly & Castle Rock, Summit Co. & June & 19,1903 \\
\hline & 1015 & W. S. Twombly & Castle Rock, Summit Co. & August & 26,1903 \\
\hline & 8 & Thos. WV. Clayton & Clear Creek, Carbon Co. & July & 3. 1903 \\
\hline & 1314 & Lorenzo C. Leavitt & Santa Clara, Waslungton Co. & Jan. & 26,1903 \\
\hline & $9-15$ & Richard R. Fitzgerald & Woodland, Summit Co. & June & 14,1902 \\
\hline $6+1$ & 10 & Heber Hoggard & American Fork, Utah Co. & Feb. & 25,1903 \\
\hline 7 & 8 & G. H. Fox & Lehi, Utan Co. & Oct. & 3. 1902 \\
\hline
\end{tabular}

A Page From the Utah State Brand Book.

The number indicates the loeation of the brand on the animal. Thus 14 refers to the right ribs of cattle.

Brands.-To find distinctive brands many changes in the original letters of the alphabet have been made and to each has been given some name. 
NAMES OF BRANDS.-

This character - placed above or below \& letter is called a bar, as $\bar{A}$ "Bar A", $S$ "S Bar". A quarter circle is used thus: $\mathrm{E}$ and the character $\sim$ is used the same $\hat{R}$ "Rafter $R$ ", and is called a "rafter" or "half diamond". W becomes the "Flying W", W the "Running W"; $\mathcal{A}$ the "Walking $A ", \infty$ the "Lazy B", $f$ the "Cross J", (1) the "Double D" or "Buckle", $\odot$ the "Cirole Dot". $\bigwedge$ This is called "Open A", made thus $A$ "Diamond $A^{"}$, and thus $A$ "Cross $A^{n}$. Again, the names of the owners sug- 
gest many brands. Pete Coffin

smears the following 0.11 over the ribs of his cattle: $P$ The oharaoters KTindioate that the cows wearing them belong to Mrs. Katie Barr ( $K$ T Bar).

Mr. Bujao, whose neighbors will insist on pronouncing his name bootjack, meets them more than half way by adopting it for his brand thus:

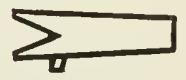

Mr. Henry Potts ohose for his brand this character;

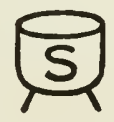

The young Philadelphian who comes west to go into the cow business keeps 
the state of his nativity ever green in his remembrance by adopting the Keystone for his brand:

Old Jack Barber, whose cattle graze all over the range in one state, weares his name into his brand thus: BR

Mr. Key takes it for his brand 0 工 or sometimes NO is placed below it in remembrance of the seduotive game of Keno, thus: ÔNO

$M r . ~ B e l l$ does the same $\bigcap_{1}$. So do $M i r$. Hert, $\bigcirc \mathrm{Mr}$. Head, and Mr. Spear 
The Lone Pine cattle co. $\Psi$, and the Pitahfork Cattle Co.-E, both have brands that wherever seen indioate their owners' names. Down in New Mexico one well-known oattleman who had four daughters, May, Susan, Anno and Jennie, met the situation by reoording for them MAY, SUE, ANA and JEN, the three letters being on the left ribs, while the single letter of the family name $S$ was placed on the hip of all of them. It is needless to say that if anybody's calves were branded the ones following these brands were. 
CHANGING BRANDS.-

There are few brands that cannot be "worked over", as the saying goes, and under the skilful manipalations of the "artistio rastler", made into some other brand. $\mathrm{H}(7 \mathrm{H}$ I) is easily turned into $\mathrm{H} \square(\mathrm{Blook}$ Bar Block), LS into 48 , while the riying on oan be ohanged to either UP(7 UP) or qP (P O P). The famous "Open Hat" brand Loan be easily made the "Flying $\mathrm{T} " \mathrm{~J}^{2}$ and the "Cross H" H entireIy lost its identity when turned into a "Window Sash", 田. Probably two of the most notorious and ingenious jobs ever attempted were the changing 
of the well-known brand of the Capitol Syndioate Co. of Western Texas, commonly known as the X I T outfit, from and the equally well-known "Hashknife" brand of the Aztec Cattle Co. of Arizona from - to

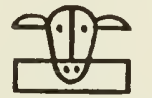
, called a "Cow Drinking out of a Water Trough". The joker who did it was oanght at it. Naturally this sort of stealing cannot be done very long or in very large numbers without detection. If the stealer is willing to take a few he will probably not be deteoted, but let his brand show up on too many 
animals during the roundups and it will quickly be noticed.

The most of such "working over" or changing, of brands was done with a "pot hook," or "running iron," a piece of $3 / 8$ - or $1 / 4$-inch iron rod about 18 inches long, with either a hook or ring turned in one end. This was carried on the saddle under the rider's leg, and heated red hot in a fire. A brand could easily be "worked over," using the iron as a painter does his brush. In some range states the carrying of such running irons was prohibited by law.

Picking Over Brands.--One method of changing the brands was to "pick" the old brand over. The brand from a hot iron shows because the hair is burned off the hide. So the "picker" takes an animal with a brand like the letter $F$, for instance, and with the point of his knife blade deftTy picks off the hair until he has a brand on the animal which shows up like this $\widehat{\underline{E}}$ and is good until the growth of the hair covers it over.

Picked brands are only used where the animal can be shipped or driven out of the country very soon or else sold to some butcher for immediate slaughter. They must of course pass the scrutiny of a keen-eyed inspector, and if he is in a hurry or the day is cloudy or it is late in the evening he may likely pass it over unnoticed. If he does discover it the man virtuously swears he knows nothing of it and the animal is turned out of the corral and allowed to go back to the range.

There is not so much of this kind of work done now as there was in the olden times, when men with large herds did not see some of their cattle for two or three years at a time and they strayed miles away from their proper ranges. 
CHAPTER X.

\section{COST OF RUNNING STOCK ON RANGES.}

In the last few years the cost of handling stock on the open ranges has very materially increased, due to many causes. In the palmy days of the business it was estimated that the cost of running between 1,000 and 2,000 cattle on the range where the owner himself looked after them was under $\$ 1$ per head per year. As there was a certain amout of fixed expense no matter whether the number was 1,000 or 10,000 , this cost was somewhat decreased as the number of stock increased, but commonly $\$ 1$ was very close to the average.

When there was plenty of range, and the country was open for the stock in all directions, excepting for the cattle, there was very little investment outside of a good home ranch, the chuck wagon and saddle horses. As settlers came in stockmen were forced to buy watering-places along streams to keep the water open, and to fence up pastures for saddle horses and bulls, requiring large outlays for wire and land. The overstocking forced them to make more provision for winter feeding, especially in the North, where the winters are more severe than in the Southwest.

All these things required a greater investment and thus caused an increase in the running expenses. On the open ranges today, on a basis of 1,000 cattle the average annual cost per head is probably more than $\$ 2$; with small bunches much more.

Cost of Grazing Cattle.-In New Mexico and the 
Texas Panhandle, where there are many large fenced pastures, it is figured at the present time that the annual cost of handling one grown animal is close to $\$ 3$. This includes taxes, general ranch expenses, lease of lands (from 3 to 10 cents per acre per year) or interest on money invested in the lands, salting and all the thousand and one little items that make up the expense account of a cattle ranch.

The year-long charge for grazing cattle on the $\mathrm{Na}$ tional Forests runs from 30 to 60 cents, with an average of 50 cents, counting those above six months of age at the time of entering. On the large Indian reservations, where the cattle are grazed under leases from the Indians, the charge is nuch more, running as high as $\$ 3.20$ on some reservations, where the competition for feed is keen. The average is probably over $\$ 1.25$ per head per year, counting everything that walks.

Cost With Sheep.-The cost of handling sheep on the ranges has gone through the same rising process as with cattle. It also varies considerably with the locality, there being a great difference in running cost between the southwestern and the northwestern sheep herds.

In 1890 an estimate made by several sheep men of New Mexico and Arizona placed the annual cost per head for handling range sheep in those territories at from 60 to 75 cents. Some Mexican owners who were able to handle their herds with cheaper help gave their cost at not over 50 cents per head. Today the average is probably not far from $\$ 1.50$ per head. This does not include depreciation, losses or interest. In 1908 several large sheepmen in Montana estimated their average annual cost at about $\$ 1.50$ per head, and with small 
herds it is probably more than $\$ 2$, leaving out depreciation, losses and interest.

The Montana sheepmen estimated that their average investment for lands, sheep and improvements equaled $\$ 12$ for each sheep they owned.

In that region, owing to climatic and other causes, the sheepmen have been forced to make heavy investments in lands, especially hay lands. Many of them, foreseeing the inroads of the settlers, also purchased or leased large areas of railroad lands on which to handle their stock part of the year. Added to this there is the annual dipping cost, which years ago was hardly considered, and many other expenses which scem to follow improvement in breeding, and it is not liard to see where the extra expense piles up.

Basis of Estimates.- In all these cost estimates no account whatever has been taken of the item of deterioration. Few sheepmen when asked to estimate the cost of running a band of sheep think to add to that cost the yearly reduction in value of the herd due to increasing age. This I believe may be placed at more than 10 per cent of the investment per year and be very conservative.

Take a band of 1,000 two-year-old ewes. Up to and including their sixth year they may be considered as in their prime. After that time they deteriorate very rapidly. The band becomes a "broken-mouthed" band and should be sold just as soon as a buyer can be found. They are not safe for range-grazing purposes, although on soft feeds like alfalfa they may be used for a year or two more. Thus the band at five years may be worth, we will say, $\$ 5$ as breeding ewes, while at seven and over they are well sold at from $\$ 2$ to $\$ 2.50$. 
The same holds good of bucks and a $\$ 50$ buck at seven years of age may be said to have passed the period of his usefulness to the rangeman, and is to be sold for whatever he will bring.

Right here is where many a sheepman has found his figures on the profits of the business sadly at variance with the final results-and he never knew just where it went.

Investment Necessary.-Twenty-five years ago the total investment of a New Mexico sheep outfit running 20,000 sheep on the open range, apart from the initial cost of the sheep, was not more than $\$ 2,000$ all told, and consisted of a few burros, a wagon or two and the necessary camp equipment. The owner did not own an acre of land or even a corral. When he sheared he threw up a brush corral somewhere on the range as close to the shipping point for his wool as possible, and the rest of the year they were at home wherever the pack burros were.

In the Northwest the large land grants belonging to the Pacific railroads rent readily to stockmen for grazing purposes at an average of about $\$ 40$ per section of 640 acres, or close to 7 cents per acre. In the Southwest, in Arizona, New Mexico and Southern California, the average is about $\$ 20$ per section. A striking example of what grazing lands will bring when put up for competitive bids is found in the prices received by the Reclamation Service for the grazing upon what is known as the "Strawberry Valley Project," in Utah. The matter is fully discussed on page 222.

Other Cost Factors.-But because it only costs $\$ 2$ a year to run cattle on the ranges, it must not be assumed that a three-year-old steer has cost his owner but $\$$ ). 
Losses from bad years, short calf crops, disease, cattle thicves cut deeply into the profits. Free grass is a myth. The eastern farmer who complains of the competition from cattle and sheep "raised on free Government grass" forgets these items which, alas, cannot well be counted.

Cost of Raising Sheep.--The report of the United States Tariff board on the cost of raising sheep on the western ranges contains some very interesting and instructive information which should be closely studied by every sheepowner desirous of reducing his expenses to a minimum, because it shows just where the money goes in handling sheep in the western range states. Tables 1 and 2 are taken from this report.

The average annual labor cost per head of sheep, including the food and lodging of the employes, is about 82 cents in our western states, about 7 cents in Australia and 23 cents in South America. In the IVest the laborers include superintendents, herders, camptenders, cooks, general ranch hands and extra men employed at lambing time. Of the total average charge, which is 82 cents, about 63 cents goes to the first three classes, who are usually employed throughout the year.

Table 1 shows the rates of wages, including board. paid in the different states. The varying nationality of the men employed has much to do with the difference which affects both wages and food costs. In the Southwest, for example, where Mexican labor is employed. the average monthly wages of a herder range from about $\$ 22$ to $\$ 35$ and the cost of his food ranges from about $\$ 11$ to $\$ 14$, making a total average monthly charge of from about $\$ 33$ to $\$ 49$; whereas in Idaho the average monthly wages of a herder are about $\$+8$ and 
the cost of his food about $\$ 18$, making a total charge of about $\$ 66$. Owing to several governing conditions the actual difference in cost is much less than the figures indicate.

TABLE 1-AVERAGE MONTHLY WAGES PAID, INCLUDING BOARD.

\begin{tabular}{|c|c|c|c|c|}
\hline States. & Superintendents. & Camptenders. & Herders. & Extra labor. \\
\hline & Cents. & Cents. & Cents. & Cents. \\
\hline Arizona.............. & 84.80 & 50.38 & 49.18 & 49.38 \\
\hline California............. & 94.05 & 68.75 & 54.18 & 55.13 \\
\hline Colorado.............. & 76.24 & 45.83 & 41.44 & 37.20 \\
\hline Idaho................ & 101.98 & 69.03 & 66.66 & 65.70 \\
\hline Montana............. & 102.22 & 68.39 & 62.70 & 62.72 \\
\hline Nevada .............. & 111.50 & 64.93 & 59.42 & 63.02 \\
\hline New Mexico.......... & 66.21 & 39.61 & 33.03 & 32.72 \\
\hline Oregon............... & 85.52 & 62.52 & 58.04 & 57.87 \\
\hline Utah................. & 89.08 & 63.06 & 64.34 & 62.13 \\
\hline Washington.......... & 89.60 & 61.33 & 60.85 & 57.54 \\
\hline Wyoming................. & 113.80 & 69.00 & 64.64 & 66.61 \\
\hline The region.......... & 90.72 & 59.82 & 52.40 & 50.37 \\
\hline
\end{tabular}

Factors Equalizing Costs.-By studying these tables it will be noted that while the southwestern sheepmen procure their labor for a much lower rate than in the northwestern states, it requires more of them to the 1,000 sheep, thus equalizing the matter. In New Mexico, for instance, it requires an average of one twelvemonth man to each 741 sheep, at a monthly cost in wages and board for herders of $\$ 33.03$ per man. In Montana it requires but one twelve-month man to every 1,556 sheep at a monthly cost in wages and board of $\$ 62.70$ for each herder, or almost double the wage cost in New Mexico. However, owing to the difference in the number of men required the net difference is against the New Mexico sheepowner, for the labor cost per head. as shown by the table, is 54 cents for Montana and 56 cents for New Mexico. 
TABLE 2-SIIOWING GENERAL AND RELATIVE COSTS OF RAISING SHEEP IN THE WESTERN UNITED STATES IN THE FLOCKS INVESTIGATED BY AGENTS OF THE TARIFF BOARD.

\begin{tabular}{|c|c|c|c|c|c|c|c|}
\hline States. & $\begin{array}{c}\text { Rate of } \\
\text { ineome } \\
\text { on } \\
\text { capital. }\end{array}$ & \begin{tabular}{c|c}
$\begin{array}{c}\text { Aver- } \\
\text { arre }\end{array}$ & $\mathrm{Va}$ \\
value & per \\
of & buil \\
sheep & a \\
per & i mp \\
head. & me
\end{tabular} & $\begin{array}{l}\text { alue } \\
\text { head } \\
\text { of pe } \\
\text { idings } \\
\text { and } \\
\text { prove- sh } \\
\text { ients. }\end{array}$ & $\begin{array}{c}\text { Labor } \\
\text { per head } \\
\text { inelud- } \\
\text { ing } \\
\text { shearing. }\end{array}$ & \begin{tabular}{c|c} 
Mainte- \\
nanee \\
per \\
head.
\end{tabular} & $\begin{array}{l}\text { Miseellane- } \\
\text { ous and } \\
\text { selling ex- } \\
\text { pense per } \\
\text { head, in- } \\
\text { eluding } \\
\text { provisions. }\end{array}$ & $\begin{array}{c}\text { Total } \\
\text { expense } \\
\text { per } \\
\text { head. }\end{array}$ \\
\hline rizona. & 5.8 & 84.75 & 0.89 & 80.79 & $\$ 0.15$ & $\$ 1.13$ & $\$ 2.07$ \\
\hline California. & 12.3 & 4.39 & .79 & .55 & .81 & .99 & 2.35 \\
\hline Colorado..... & 7.6 & 4.15 & .44 & .60 & .26 & .90 & 1.76 \\
\hline Idaho.......... & .8 & 5.11 & 1.02 & .59 & .96 & 1.30 & 2.95 \\
\hline Montana...... & 5.6 & 4.15 & 1.42 & .54 & .54 & .97 & 2.05 \\
\hline Nevada....... & I1. 3 & 5.13 & .95 & .76 & .36 & 1.11 & 2.23 \\
\hline New Mexico.. & 7.2 & 3.97 & .59 & .56 & .18 & .91 & 1.65 \\
\hline Oregon. & 4.7 & 3.62 & 1.30 & .56 & .63 & .80 & 1.99 \\
\hline Utah.......... & 9.9 & 5.08 & .71 & .69 & .38 & 1.20 & 2.27 \\
\hline Washington.. & 17.3 & 3.71 & .87 & .74 & .62 & .77 & 2.13 \\
\hline Wyoming .... & 4.0 & 4.44 & .75 & .72 & .36 & 1.01 & 2.09 \\
\hline Total... & 6.2 & $\$ 4.41$ & 0.89 & $\$ 0.63$ & 80.46 & $\$ 1.02$ & $\$ 2.11$ \\
\hline States. & $\begin{array}{c}\text { Average } \\
\text { monlhly } \\
\text { cost of } \\
\text { provis- } \\
\text { ions per } \\
\text { man. }\end{array}$ & $\begin{array}{c}\text { Percent- } \\
\text { age of } \\
\text { increase } \\
\text { (lambs). }\end{array}$ & $\begin{array}{c}\text { Capital } \\
\text { per } \\
\text { head. }\end{array}$ & $\begin{array}{c}\text { Average } \\
\text { number } \\
\text { of sheep } \\
\text { to each } \\
12-\text { month } \\
\text { employe. }\end{array}$ & \begin{tabular}{c|c}
$\mathrm{e}$ & Aver- \\
$\mathrm{r}$ & age \\
$\mathrm{p}$ & pounds \\
$\mathrm{h}$ & per \\
e. & elip. \\
\end{tabular} & ds $\begin{array}{c}\text { Net } \\
\text { eharce } \\
\text { against } \\
\text { wool per } \\
\text { pound. }\end{array}$ & $\begin{array}{l}\text { Selling } \\
\text { price } \\
\text { per } \\
\text { ound of } \\
\text { wool. }\end{array}$ \\
\hline Arizon & $\$ 13.88$ & 59.3 & $\$ 5.64$ & 780 & 7.1 & $\$ 0.105$ & $\$ 0.156$ \\
\hline California.... & 14.75 & 76.4 & 5.18 & 1,225 & 9.1 & .071 & .145 \\
\hline Colorado..... & 11.60 & 61.9 & 4.59 & 853 & 6.1 & .087 & .142 \\
\hline Idaho......... & 18.43 & 67.2 & 6.13 & 1,223 & 6.3 & .173 & .181 \\
\hline Montana...... & 17.52 & 71.9 & 5.57 & 1,556 & 7.6 & .138 & .185 \\
\hline Nevada....... & 14.42 & 74.6 & 6.08 & 1,349 & 6.5 & .041 & .152 \\
\hline New Mexico.. & $11.2 \mathrm{t}$ & 57.7 & 4.56 & 741 & 6.6 & .083 & .139 \\
\hline Oregon....... & 13.38 & 79.6 & 4.92 & 1,641 & 8.9 & .109 & .141 \\
\hline Utah.......... & 19.00 & 72.5 & 5.79 & 1,130 & 7.5 & .093 & .173 \\
\hline Washington.. & 14.60 & 92.5 & 4.58 & 1,231 & 9.3 & .005 & .118 \\
\hline Wyoming .... & 19.00 & 62.4 & 5.19 & 1,250 & 7.2 & .124 & .157 \\
\hline Total........ & $\$ 15.25$ & 70.3 & $\$ 5.30$ & 1,097 & 7.3 & $\$ 0.109$ & $\$ 0.159$ \\
\hline
\end{tabular}

This difference in the number of men employed is due to several causes. The ranges in the Southwest are somewhat rougher, water and feed scarcer, the labor 
is not quite so efficient, and the older sheepmen have always employed more help than they actually needed, just because it was handy and comparatively cheap. There is, however, no valid reason why this differecne should be so great, and the opportunity for the sheepgrowers of the Southwest to economize in this respect is obvious.

In Table 2 the "maintenance cost" means all the various items of feed for the sheep, the bucks, saddle, pack and work animals used, and all grazing fees on National Forests or other leased lands. Arizona stands lowest in this respect at 15 cents per sheep per annum, with Idaho the highest at 96 cents per head. This difference is due mainly to the winter feeding expenses of the Northwest and the higher rental value of their grazing lands.

Colorado is lowest in the average shearing, with 6.1 pounds, Washington the highest with an average shearing of 9.3 pounds. The column headed "net charge against wool" is what it costs the wool-grower to produce a pound of wool. The Washington wool-grower with his heavy mutton sheep and high average shearing shows almost no charge at all against the wool by the time it is offered for sale. This "charge against the wool" averages 11 cents per pound for the range states, in the Ohio region about 19 cents, in South America between 4 and 5 cents and in Australia approximately nothing, the sales of mutton practically covering every expense of the flock, leaving the wool clear of all charges.

From these tables it appears that the average annual cost of running sheep per head in the western states is approximately $\$ 2.11$, while in the Ohio region it is $\$ 2.78$. 
The most reliable authority on cost of sheep-raising in England places the total annual cost there, including labor, at $\$ 3.63$ per head. It is still higher in France and Germany. 


\section{CHAPTER XI.}

\section{STOCK ON RANGES IN NATIONAL FORESTS.}

With approximately $160,000,000$ acres of land inside the boundaries of the various National Forests at the present time, the control of grazing matters on the pub lic lands in the United States is practically in the hands of the Forest Service. The importance of this range is increased when we remember that probably threefourths of it comprises the summer ranges, which are of vital necessity to stockmen, especially sheepraisers. The summer range is today the key to the whole grazing situation in the West.

Timber the First Consideration.-Inasmuch as the prime consideration in establishing the National Forests was the preservation and perpetuation of the timber supply, and the protection of important watersheds, it naturally follows that all other demands for the use of those areas may be considered only after the main one of forest preservation. The control of grazing on the National Forests is of course greatly complicated by the questions involved in protecting the timber and also the watersheds of the various mountain ranges over which the National Forests extend; and it becomes necessary for the Government in handling the stock on the National Forests to consider it as rather a secondary matter, in which the questions of reproduction and protection of the growing timber must necessarily come 
first. This has been the cause of much criticism and fault-finding on the part of the stockmen who, looking only at their own side of the case, were unable to appreciate the reasons for keeping out all stock from certain areas in some cases, and in others only certain classes of stock.

Therefore it must be borne in mind that where stockmen are refused permission to take their herds into particular portions of National Forests it is done because the grazing of stock is known to be injurious to the forest growth and would defeat the object for which the forests was created.

It has always been hard for the stockman to understand these reasons, and doubtless always will be, because of man's natural inclination to judge things from a selfish standpoint. Moreover, the average stockman is not well posted on the various questions concerning the reproduction of timber, and is apt to scoff at the position taken by trained foresters as to the injurious effects of stock grazing over areas where reforestation is desirable.

To him a tree is an object 100 feet high and a foot or more thick, and he forgets or perhaps may not know that a yellow pine seedling two years old is often not more than that many inches high, scarcely showing amid the grass, leaves and other ground cover where it may be snipped off by his sheep or trampled into a shapeless wreck by some heavy-footed steer.

There are few of the National Forests which today are not open to grazing of some kind of stock in every part, although on some of them it has been considered advisable to close certain areas to grazing of all kinds. A prominent case of this kind is the watershed area about the sources of the water supply of several western cities, 
notably Portland, Ore., and Salt Lake City, Utah, where it was considered advisable absolutely to forbid the use of the range to all kinds of stock. Again on the Manti National Forest in Utah the little city of Manti, before the creation of the forest, had been repeatedly damage by heavy floods which swept down the canyon from the mountains above them. A study of the situation by the Manti people led them to believe that the seriously overgrazed condition of the mountains about the head of the canyon was the cause of these floods. The grasses and other vegetation were all gone and the ground was bare and packed hard by the constant trampling of the stock. Due to their wishes, the Forest Service prohibited all grazing upon an area of considerable extent, and after four years' experience the people of Manti are unanimous in the belief that the effect of this has been practically to eliminate the floods.

On several of the National Forests where large irrigation works are being erected under Government supervision, the Reclamation Service has seen fit to prohibit the grazing of sheep about the heads of all the water courses which flow into the reservoirs being built. The best example of this exclusion is in Arizona, where the Government has erected at a cost of more than $\$ 9,000,000$ the great Roosevelt Dam with a reservoir capacity sufficient when once filled to irrigate 200,000 acres of land for at least two years without being replenished.

The region about this reservoir is one of the best winter sheep-grazing areas in the Southwest, and at the time the Government took charge of the irrigation project probably carried during at least four months of the year 300,000 sheep, besides fully 100,000 cattle. The 
result was that the entire watershed draining into the Roosevelt Dam was seriously overgrazed. One of the first studies taken up by the engineers was the question of silt; after a careful survey of the area it was deemed advisable to protect the watershed by creating a $\mathrm{Na}$ tional Forest there, and absolutely to prohibit all sheep and goats grazing upon it.

It was but natural that the sheepmen should find considerable fault with this ruling, but when one considers that the number of sheepmen involved was probably not more than 200 as against fully 50,000 people living under the Roosevelt Dam system, it is easy to see that it was only a question of the greatest good for the greatest number. The Forest Service on publishing this prohibition of sheep gave the sheepmen sufficient notice, so that they had at least two seasons in which to prepare for the change. It is possible that in the future similar areas around other national irrigation works will have to be protected from overgrazing where the cuestion of silt coming down the streams and filling up the reservoirs is a vital one.

Liberal Policy Followed.-In considering the various questions of handling live stock on the National Forests, the men charged with the control of grazing have endeavored to meet them in a broad and liberal spirit. IV hile full consideration must be given to the questions of reproduction and protection to the forests, it has always been their earnest desire to give the stock interests every possibie use of the range. The small stockman and home-builder is given free grazing for his work and milk stock up to ten head, while the hunter, camper, miner and traveler is allewed to graze his stock without charge wherever his wanderings take him. 
In studying the subject much has been learned as to the possibilities of utilizing the ranges in the National Forests and at the same time allow for the growth of the timber. The question is a broad one, and must always be met in a fair spirit by the grazing men on one side and the trained foresters on the other. From the studies so far made it is evident that on those ranges where reproduction is desirable, by keeping the stock, especially sheep, off certain areas for periods of years the young timber will get its growth to a point where it can not be damaged by stock. Such areas can therefore be temporarily closed, and once the young timber is past the danger-stage can be again opened for grazing. If people are going to build houses they must first be fed, and there is little danger that the areas within the National Forests will be handled so as to leave the forage on a single acre of it untouched by meat-producing animals, unless it is clearly shown that such exclusion is absolutely necessary, and that the value of the timber produced on the area will be greater than its meat-raising capacity.

Improving the Ranges.-Through the conservative and practical administration of grazing affairs on the various National Forests, the carrying capacity of many of the ranges is gradually being improved, and while it is true that on some of the forests the number of stock grazing today is considerably less than it was a decade ago it is also true and much more to the point that the physical condition of the stock now grazing there is much better, and there is a greater stability to the business than under the old conditions.

One of the most destructive uses of the mountain ranges under the old system was the early grazing be- 
fore the ground was dried out sufficiently in the spring and the young grass was hardly started. It was simply a race to see who would get into the mountains first and thus obtain possession of the best ranges. The result was that the grass on thousands of acres was destroyed, when if the stock had been kept off for a short time longer the feed would have been so far advanced that it could not be injured.

In handling stock on the National Forests the ranges are divided into districts, each of which is in charge of one or more forest rangers. The rangers see to it that the stock of each permittee is as nearly as possible kept upon the range assigned to it, and that each respects the rights of the other. Sheep are not allowed to be bedded down more than six successive nights in any one spot, nor near the banks of running streams, springs or other watering-places.

Stock driveways are established wide enough to admit of reasonable grazing en route, over which stock may be driven under a permit, which is in most instances granted without charge. The exceptions are where the trip is of such a length that the stock is upon the forest for an unusually long period and derives more or less benefit from it. By this means the stockmen who are not permittees are given opportunity to cross back and forth to reach either their private lands or ranges upon the Government lands surrounding a national forest.

Elimination of Tramp Stockmen.-On the National Forests the tramp stockman, and this applies equally to both sheep and cattle, has been practically eliminated. No more can men whose sole possession is a herd of sheep and a few pack burros sweep over the country regardless of the rights of others, taking the cream of 
the range wherever they find it. This was also done by cattlemen who purchased herds of steers in the Southwest, shipped them to some point, unloaded and turned them out on the mountain ranges, although well aware of the fact that they were already stocked by resident owners to almost their full capacity. Under such conditions the ranges were ruined and the local owners and settlers practically driven from the range.

Tramp Sheepman in California.-In California in the southern Sierras the attempts of the tramp sheepmen to dominate the range resulted in such an intense sentiment against them that the Government was forced absolutely to prohibit all sheep grazing upon areas which had hitherto supported an immense number of sheep. There is no doubt that a large number of sheep could safely be grazed today on those ranges without injury either to the watershed, the timber; or the settlers. In fact, their presence in keeping down the chapparal growth, especially the snow bush (which since sheep have been kept out has spread at a tremendous rate, forming dense, almost impossible jungles), is a decided benefit to the ranges. But the general public is so strongly against it, owing to the drastic lessons of the past, that the mere suggestion of such action would undoubtedly arouse a very determined opposition to it.

Changing from Cattle to Sheep.-The question of men changing from one class of stock to another (as cattlemen selling their cattle and replacing them with sheep) is one which can not always be allowed on the National Forests. One of the chief reasons for this is the protecting of the watershed and the timber. Another factor is public sentiment. Where the region is one which has always been used for a cattle-raising 
range, the question must be seriously considered before action is taken upon it. If the silvicultural projects will not be injured and the sheep can be grazed without interference with the cattlemen using the range, it may generally be looked upon favorably; but if public sentiment is opposed to it, as in the California case mentioned, and the sheep can not be grazed without more or less interfering with the stock already there, it should not be granted. These questions must naturally be considered and each case decided upon its own particular merits, because no general rule can be laid down which will apply alike to all.

Cattle vs. Sheep.-In the opinion of many sheepmen the Forest Service has discriminated against their industry in favor of the cattle-raiser. While not admitting discrimination in the sense meant by the sheepmen, the Service holds that they are handling forested areas and not stock ranges, and that all stock grazing being primarily more or less objectionable from the point of view of a forester they are justified in encouraging the grazing of the class of stock which in their judgment does the least damage to the forest areas.

Another point is the character of the business. From the days of Abraham the sheepman has been a nomad and the cattle-raiser a tiller of the soil. The Forest Service believes, and rightly, that the settler who takes up a little piece of land and makes a home for himself and family is entitled to first consideration in the use of the range about him. Every such settler has as part and parcel of his home-building operations a few horses and cattle, and must graze them near his habitation. The sheepman, on the contrary, can drive his herds to the feed, and wherever night overtakes him there he is at lome. 
Besides, from the nature of the business, more people are cattle-raisers than sheep-raisers. A settler can start out with a milk cow and a work tean and hope to see them increase as his fortune improves. The sheepman cannot make such humble beginnings but must perforce start in with a band sufficiently large to pay for herding and handling them.

Every settler who takes up a piece of land or buys a little home becomes at once a horse and cattle-raiser, but, based upon the data available, not more than one in every twenty-five is a sheep-raiser. Therefore the Forest Service believes that the cause of forestry will be advanced by giving the cattle-raiser the preference over the sheep-raiser whenever it becomes necessary to decide between the two. This cannot be called discrimination; it is rather a decision as to which of two good things is the better for the whole people.

The Permit System.-The use of the National Forests is granted the stockmen through a system of permits issued generally about the first of April of each year, and for such periods of time as experience has shown meet the conditions on the various forests.

The permit issued shows the number of stock to be grazed by the person holding it, and specifies the range on which the animals are to be grazed. The charges are made on a per capita in preference to an acreage basis. The per capita permit is more flexible and the control of the ranges far more satisfactory than where an acreage charge is made and a specific area leased to the permittee. In granting these permits priority in the use of the range is first considered, and preference given to those who have continuously used the range for the longest period. In order that there may be no monopoly 
of the range, protective and maximum limits are established. The protective limit is the number of stock which small owners will be allowed to graze without reductions, excepting for certain specific reasons; while the maximum limit is the greatest number which any person or corporation will be allowed to graze. The protective limit is generally based on the number of stock which the average settler can care for in connection with his homestead and support himself and family in a modest way.

New Settlers.-In order to allow the use of a portion of the range on fully stocked forests by new settlers all permits above the protective limit are scaled down each year on a certain well-defined percentage, which must be no greater than will result in a total reduction, equaling 3 per cent of all the stock allowed to graze upon that particular forest during the year. Thus if the forest is carrying 100,000 sheep the gross reduction from the larger permittees will accumulate surplus range for 3,000 sheep to be taken up by new applicants. This makes the change come more gradually and allows time for the larger owners to regulate business.

The number of stock thus gained is given to the new men, who must in every case be bona fide settlers and home-builders, depending on their lands for their living. In many instances the number of new applicants is far in excess of the capacity of the range to care for them, and in such event the needs of each individual applicant are considered and those who in the judgment of the Forest officers are most dependent on the range are granted the permits. Of course where the range is not fully stocked these protective and maximum limits are not always strictly enforced. 
The Cash Value of Permits.-Usually the advantages of grazing stock on the National Forests are so apparent that the permit has come to have a great pecuniary value, resulting in a premium on both ranches and stock located within or adjacent to National Forest ranges. Instances are known where sheep grazing under permit on a Forest have been sold for as much as $\$ 2$ per head more than the market value, solely because the ranch which went with the purchase controlled the range in the National Forest on which the sheep grazed.

Permits Nonsalable and Nontransferable.-Permits to graze stock on a National Forest are not transferable. The Government recognizes the claims of the pioneer settler, who was occupying the ranges when the forests were established, by allowing him to remain in possession of them so long as he complies with the regulations. But it cannot for very obvious reasons permit him to designate his successor either by sale or inheritance. To do so would result in range monopoly, and the Government would lose control of its own lands.

A purchaser of stock grazing on a National Forest may secure a permit for the rest of the season during which the original permit ran, but at the beginning of the next grazing season he must file an application, and take his chances of being granted a permit based entirely on his individual merits as an applicant and not by right of purchase from the former permittee.

If, however, the transfer includes both the stock and such necessary ranch property as is clearly commensurate with the number of stock involved, and required for its proper handling, the permit may be renewed to the purchaser, less any reductions that would have been made on the original permit or are required by the regulations. 
The object of these regulations is to prevent speculation in permits and the handing down of grazing privileges from one person to another without the power of the Government to control it.

Permits for More than One Year.-On some of the forests where grazing conditions are well established, and there are no range controversies, applications are received for a period of more than one year, usually five years. While this permit is issued annually, the holder is given assurance that except for certain stated reasons and causes he may continue to use the same range and graze the same number of stock and the annual permit will be renewed each year for the term specified in the application. This gives the holder of such a permit a certain permanence in the use of his range and the number of stock to be grazed under it.

Drifting of Stock onto Forests.-Where the stockmen, especially cattle-owners, are grazing their herds in the vicinity of the National Forests, and the drifting cattle naturally work back and forth across the open boundary line, the matter is adjusted under an "on and off" permit, which allows for a certain proportion of the cattle being on the forest at all times. This obviates the necessity of the stockman herding his cattle or erecting fences to keep them from going on the forest, and has proved a satisfactory method of meeting the situation. The Supreme Court of the United States has decided that the burden of keeping the drifting stock off the forests rests on the owner of the stock and not the Government, state or local laws to the contrary notwithstanding.

Fencing Privileges.-Stockmen using the National Forests are also permitted to fence land for pasturing 
purposes, a privilege which cannot be granted them by any one on public land outside of the National Forests. This is a valuable privilege, because of the necessity for such pastures in handling the stock. Again, the Forest Service allows the erection of drift fences where such fences are clearly a benefit to the forest, and by this means the drifting of stock from its proper ranges is stopped and the expense of handling the animals much less than where it was necessary to ride for miles to find cattle that had drifted from their owner's range.

The allotting of the same ranges to stockmen through successive years also tends greatly to increase their personal interest in the preservation of the range, because they know that if they leave their range in good condition in the fall no one else is going to rush in there after they have left it and graze it to the bone before the snow drives them out. Therefore under this system the desire to overgraze an area is not so great, and thus the carrying capacity of the ranges is continually being improved.

Fees Moderate.-It is a well-established fact that the fees charged for grazing on the various National Forests are on an average not more than one-third those charged for grazing on private lands of equal value. When the National Forests were established it was not the intention to charge such an amount for the grazing privilege as to result in a profit to the Government or place it on a commercial basis, but only to ask the stockman to pay a just proportion of the administrative expense in handling the National Forests.

There is no doubt whatever that if the Government adopted the plan followed on the various Indian reservations, which are practically private lands and being 
administered as such, and put the privilege up under competitive bids, the amount received would be greatly in excess of what is now paid.

Possibility of Competitive Bids.-Petween two stockmen, one grazing his herds on the open public ranges and taking his chances in obtaining its use for his stock as against his neighbor, and one grazing his stock on the National Forests where he is secure in the possession of his range, the latter has by far the better of it and should under all commercial principles pay a much larger sum for the use of the range in order to equalize matters.

It is possible that eventually, due to the strong demand for range, the Forest Service will be forced in self-protection to meet this question by some system of competitive bids where after taking care of the small settlers for a certain definite number of their stock at a fixed per capita cliarge the rest of the range will be given to those who bid the most for it. Such a system will possibly result in more or less range monopoly and in some cases may crowd out the intermediate man, who is neither entitled to recognition as a small owner nor able to command the capital to compete with the larger owners.

Result of Competitive Bids.-That this may happen has been indicated by the success of the Indian office in selling the grazing privileges on the various Indian reservations in the West.

Prices from two to four times those charged by the Forest Service have been received for these lands on which the grazing is practically the same.

The White Mountain Indians in Arizona receive 30 
cents per head for sheep and $\$ 1.40$ per head for cattle for year-long grazing on their reservation, while on the adjoining Apache and Sitgreaves National Forests the Forest Service is charging but 12 cents per head for sheep and 40 cents for cattle for the same time. Yet the two areas are practically the same from a grazing point of view.

On the Crow Creek Reservation in Montana the highest bidder for the grazing pays 35 cents per head for sheep and $\$ 2.17$ for cattle by the year, while on the Big Horn National Forest immediately alongside of it with precisely the same sort of range the Forest Service charges 15 cents per annum for sheep and 45 cents for cattle.

A withdrawal of some 150,000 acres of grazing land in the Uinta National Forest in Utah for reclamation purposes in the Strawberry Valley placed the area under the charge of the Reclamation Service.

While under the supervision of the Forest Service the charge for grazing this land was only 10 cents per head. the Reclamation Service had little trouble in leasing the area at a rate that brings them in a rental of 42 cents for each sheep grazed upon it.

The state of Utah owns large bodies of lands within several of the National Forests in the state. An agreement was entered into between the state land board and the Government by which the Forest Service undertook to handle this land and turn over to the state the net receipts after deducting the cost of caring for it.

After two years the state revoked the agreement. nwing to the fact that it was offered much better prices bv individuals for its use than the fees received from the Forest Service amounted to. The state had no trouble 
at all in leasing it out to large stockmen at greatly increased rates.

The same happened in South Dakota where the state land board had precisely the same agreement. In Colorado and New Mexico the state lands are leased in large blocks at a minimum rate of 4 cents per acre, while just as good land in the forests around the state land is grazed by stockmen at a price which is less than 1 cent per acre.

Exchanging Lands.-In co-operating with the owners of land within the boundaries of the National Forests such as the railroad grants and other private holdings, the Forest Service has adopted a very liberal policy by which means the lessees or owners of these lands are enabled to exchange with the Government for an equal acreage all in one body. For instance, the railroad sections which are alternate sections could not possibly be grazed except with great danger of trespassing on the adjoining Government sections. Therefore a man who leases ten sections of railroad land lying between as many sections of Government land is given in exchange ten sections of grazing land in a solid body, in return for which he allows his leased lands to remain open to other stock grazing under permit. In this way the lessee or owner of private lands is enabled to get the full benefit of his holdings and have it in one solid body where he is far better able to handle his stock and utilize the feed than he would be on his scattered sections. Much the same privilege is allowed persons who desire to fence up areas for pastures. By means of an exchange of this sort the owner or lessee of the land is given the right to enclose an equal amount of Government land up to a maximum of 320 acres, leaving his own land open in return. 
Stock Losses Less.--It has been proved beyond any question that on the National Forests with a constant supervision on the part of the rangers and other forest officers, the loss from straying and stealing of stock is much less than on the open ranges. The losses from predatory animals have also been greatly reduced on the National Forests where hunters are especially employed to kill them, and the various forest officers are also encouraged to capture and destroy such animals whenever opportunity offers.

Policy of Government Growing in Favor.-When the National Forests were first formed, and the Government began to make a charge for grazing stock on them, the stockmen who had hitherto used the ranges without restriction of any kind found great fault with the system. For several years there was in many parts of the West a strong opposition to the plan. Today, however, there is no doubt that if it were left to a vote of the stockmen whether to abolish the National Forests and allow grazing under the old conditions or continue under the present plan, 90 per cent would be in favor of its contimuance.

During 1912 nearly 7,500,000 sheep and goats and $1,500,000$ cattle and horses grazed under permit on the various National Forests. The number of permits exceeded 26,500, of which 21,188 were for cattle and horses and 5,313 for sheep and goats.

In estimating the number of sheep actually grazed the total is undoubtedly almost twice that shown by the permit numbers. This is because of the policy of the Forest Service in not making charge for animals under six months of age. The sheepmen almost universally avail themselves of this advantage by taking into the 
forests only ewes either with lambs or to lamb after entering. Thus while an owner may have a permit for 1,500 ewes he may really take into the forest and graze about 2,500 or 2,600 sheep, young and old.

For lambing a slight fee is charged, commonly 2 cents per ewe, and so as far as possible the lambing grounds are protected from other grazing, so that they may be in the best possible condition at this time.

When one stops to consider the conditions under which these animals were grazed, the various and conflicting demands on the Service for recognition either for more stock or more range, and the necessity for controlling men who had in the past been practically masters of the range by virtue of their might, it is surprising to find how few cases of error there have been on the part of the forest officers concerned. There is no doubt that as the stockmen become better acquainted with the regulations and the forest officers more conversant with the needs of the stockmen and the ranges, these complaints will be reduced to a minimum. 


\section{CHAPTER XII.}

\section{THE CARE OF THE RANGE.}

When the first settlers and stockmen came into the West, they found an almost virgin country for their stock. As far as the eye could reach stretched billowy prairies covered with grasses, the accumulation of ages. This carpet of grass made a reservoir whereon every drop of water and flake of snow that fell were received and saved for future use.

There were no roads or trails cutting and gashing the country to offer a ready runway for the moisture. The spring snows lay long under the folds of the old grass, weeds or brush that covered the ground. Let the wind blow as it pleased, it could not blow the snow entirely off the ground. A certain amount of it was allowed to remain to melt and soak into the ground, thus bringing the green sprouts out early in the spring, and it took a long dry spell to make any great impression on the soil.

When the settler's stock began to spread out and, here and there, a fire was started under the mistaken impression that it benefited the grass, this covering disappeared, and when winter came there was nothing left on the ground to cover it up and offer a safe resting place for the snow and rain.

Burning Off a Range.-The burning off of a range in the fall or winter in order "to make better feed next 
spring" is one of the greatest mistakes the western man ever made. There is nu doubt that he obtamed the idea from the Indians, who seem to have practiced it more or less. Theoretically it appears to be a good thing.

Take a great sweep of open prairiee, covered with considerable wld, dry grass. Burn a strip across it and in the early spring when the grass begins to green it will show up to a decided advantage against the yellow of the unburned area. The alvocate of burning will point to it as a positive and unimpeachable result. "Look at the burned strip and then at the unburned place and it speaks for itself," he declares. So it does if one duesn't give the matter any more than a superficial thought, as too many of us do.

True it is that on the burned strip the green grass is easily seen. But get down on your knces and peer into the old grass on the unburned strip, and you will find as much young grass starting up under its cover, giving it a protection against the frosts and drying winds that the grass on the burned strip lacks.

Comes a cold night or windy weather and the grass on the burned strip curls up and either dies or is set back in its growth very materially; while the other part under the cover and protection of the old grass. which also holds every drop of moisture that falls on it, is safe and sheltered and does not feel the change in conditions.

The man who burns off a range to get better grass loes himself and the range the greatest possible injury, and if he persists in it will eventually kill out the best of the grasses. which will not stand the repeated attacks by fire and only the worthless and useless weeds and plants will persist. 
Range Erosion.- The trails that the cattle made leading into the watering-places or the sheep dragging along one after another, on the ranges, furnished convenient passages for the water to follow. Little trails where the stock had worn out the grass to the bare ground soon became deeper. The erosion left the bottom full of small pelbles which hurt the feet of the stock. They started a new trail just alongside the old

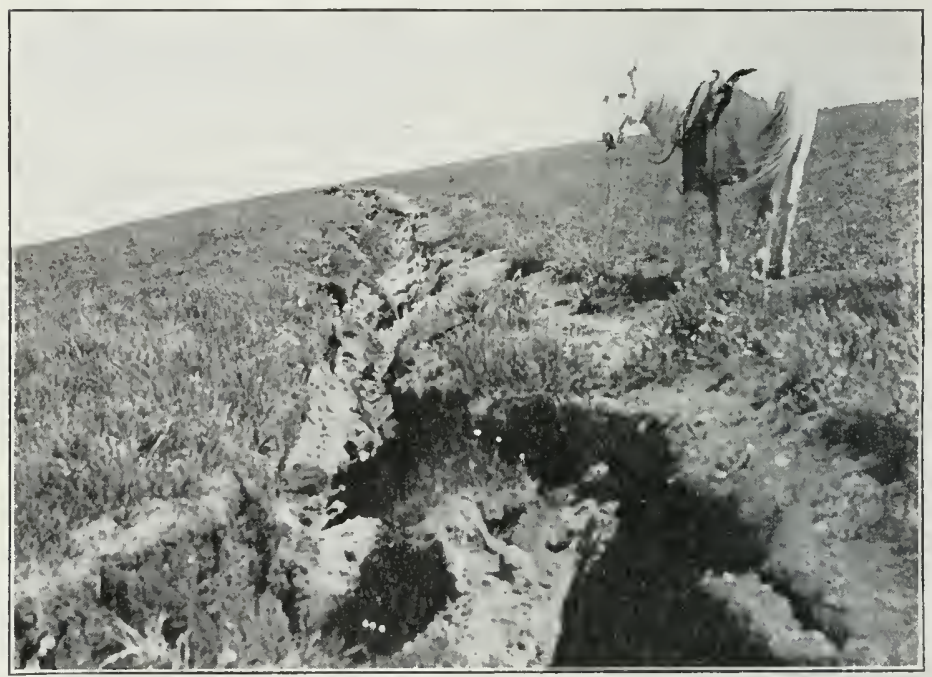

"Down These Trails the Water Finally Tore."

one and thus the process was repeated until one can see on many western ranges a score of such trails side by side, stretching for miles across the prairie towards watering-places.

Down these trails the water first crept, then ran and finally tore, digging down deep into the ground until great washes were formed. Little trails leading into 
these larger ones furnished fine feeders for them, and thus by a series of natural but nufortunate conditions a system of drainage was put inte effect that was sufficient to drain off almost every drop of water that fell on the surface. Instead of soaking into the soil it ran

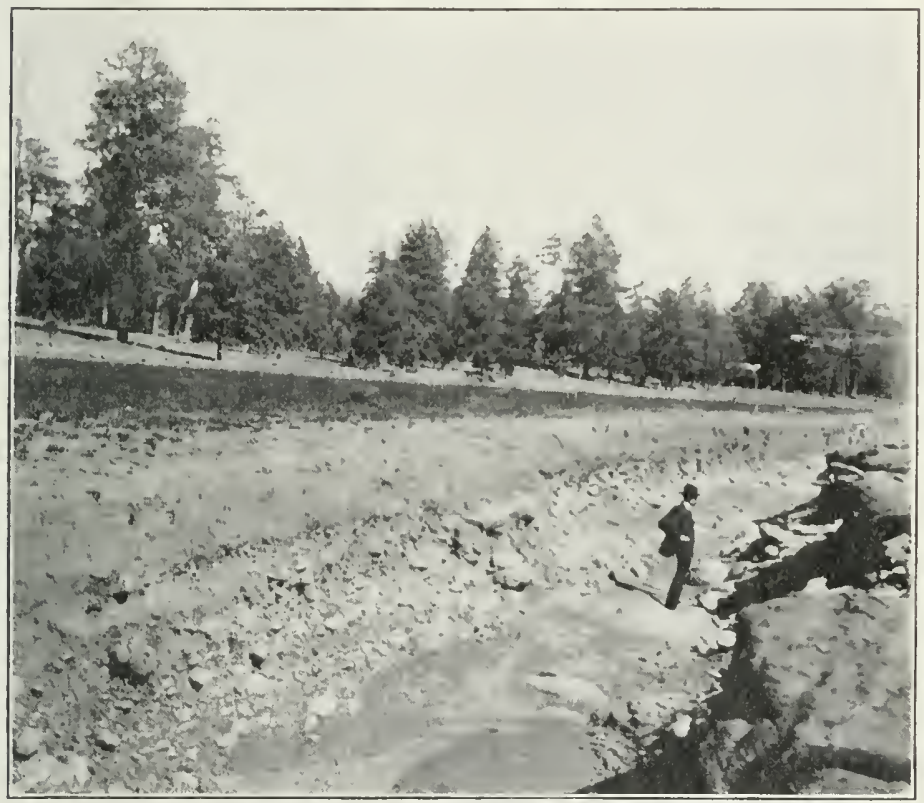

Old Stock Trails Washed Out, Forming Arroyos in Meadow Land.

off just as rapidly as it could, taking with it the valuabie topsoil and cutting deeper and deeper those washes or arroyos which today have seamed and scarred the western ranges in every direction.

Follow down the main Santa le road in northern New Mexico and one can see from the train and close to the track the signs of these trails for many miles, 
some of them fifty trails wide. The damage done by trails cannot be stopped. Once they begin to cut and form a little "pour-over" in their path, the matter seems to be beyond control, excepting at tremendous cost of labor and material.

It seems almost impossible to stop the erosive action of the waters. I lave been seen lovely mountain meadows drained and ruined by such an arroyo which cut across them, beginning at the lower end with a little pour-off or waterfall, and working back year after year, with increasing rapidity in spite of everything that could be done to stop it.

In one instance from a little cow trail in the grass an arroyo was cut which in ten years was almost a mile long, fifty feet wide and fifteen feet deep and a meadow. full of marshy places and renowned all over the region for its hay-producing value, was drained as dry as a dusty road.

Ever since the first settlement of the western ranges this work of erosion has been going on. Like the cattle trails, the wagon roads offered equal facilities to the run-off of the water. The old Santa Fe trail can today be followed for miles by the wide and almost barren streak which it occupies on the prairies.

The first wagons broke the road which, after being used for a time, begun to slow holes and ruts. Then a new one would be made just off the first which in turn would succumb to the wet weather and ruts, and thus in time the road wonld spread out over a wide area.

Wherever the road led down a slope the water soon found a handy outlet in the wheel tracks and the rest was only a matter of time. The ruts were worn 
down deeper and deeper until the road became unfit for use, owing to the high centers.

Thus the water that formerly flowed slowly across the grassy prairies was drawn off as rapidly as in the paved streets of a city, and was lost to the regetation

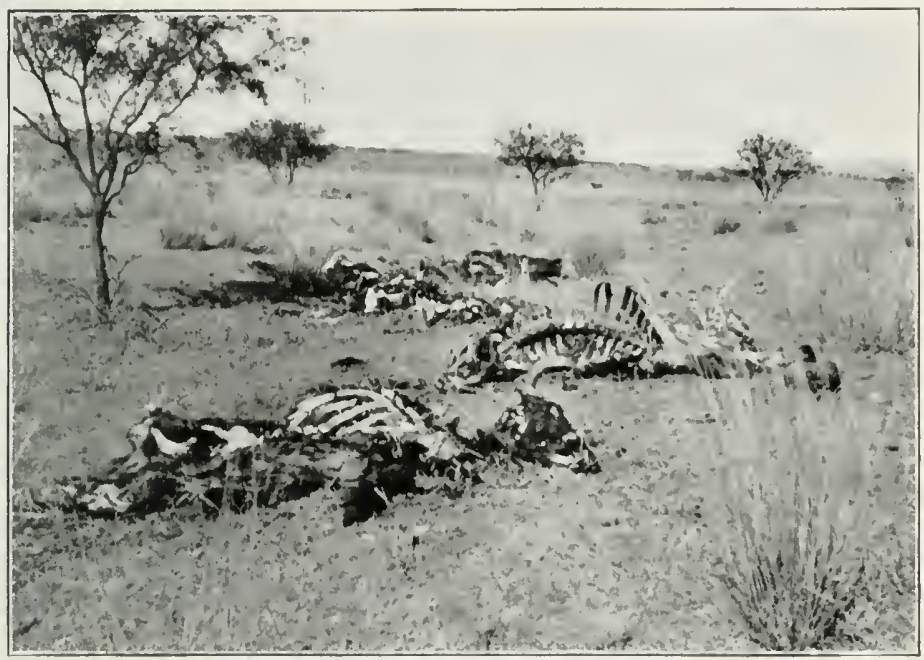

An Arizona Range After a Hard Spring.

which so badly needed it. This was one of the reasons for the failure of the western ranges.

Overstocking.-The greed of the settlers and the utter lack of responsibility for preserving the ranges for future use were other reasons for range failure and depreciation. It was all free, open grazing; Uncle Sam owned it and "if we did not get it somebody else would." This was the general feeling.

Tens of thomsands of cattle and sheep were thrown onto ranges only to starve and die. On an average little 
of the range country west of the Missouri was capable in its best days of supporting more than one cow to every twenty-five acres and keep it up year after year. Today, taking the whole western range country, including the areas in Arizona and New Mexico, which are principally desert, it is doubtful whether on an average it will support more than one cow to every seventyfive acres.

The splendid forage grasses that covered all this western range were eaten off and the roots uncovered by the winds which blew all the soil from them. The earth too was trampled and packed hard as a floor by the feet of the stock wandering back and forth across it. Robbed of the required amount of moisture through the drainage operations of these various trails and roads and the hard impervious surface of the ground, the native grasses have a hard struggle to make headway towards revegetating the overgrazed areas.

Besides this the stockmen were slow to realize that the range could no longer support the same number of stock, and until Providence stepped in and by a series of hard winters swept the surplus stock from the ranges, little was done to reduce the number. Bitter as has been the lesson the stockmen still will not see the necessity for more conservative handling of the ranges. or, seeing it, will not accept the only possible way in which it can be brought about, which is, government control.

Time after time has the matter been brought to their attention through conventions and meetings, but so far there is a fatal lack of harmony among these men who are the most vitally interested. The opposition comes mainly from the sheepmen, who, while fully realizing 
the conditions, yet "fear to 1 y from ills that are to evils that they know not of."

Generally speaking, the cattlemen of the entire western region are heartily in favor of the plan. They have long realized the absolute necessity for the protection afforded the rangensers through a liberal policy of Govermment control of the range. Their business does not demand a great expanse of range, as does that of the sheepmen; hence they can accept the promises of the Government experts that the matter can be so handled as to give every man his fair share of the range and not interfere with persnnal rights gained through long use of the range.

Success in Handling the Range.-The success of the Forest Service in handling the range is pointed to as an example of what may be clone in the matter. The larger sheepmen, smarting from what they term the interference of the Forest Service with their business, in cutting down their herds to make room for the small settlers denonnce the plan, and declare that while things are bad enough as they are, under Govermuent control they would be worse.

There is little real foundation for this feeling excepting that Govermment control wonld put an end to the hogging of the ranges by any men, no matter what their business. Today the man with the great herds lias the matter almost entirely in his own liands. He can allow the little fellow to live and obtain his part of the range, or he can snuff him out in one season. To the credit of the stockmen of all classes, this is not commonly the case today, although it was, not many years ago. Generally speaking, the old plan of riding roughshod over the little herds is a thing of the past. Never- 
theless, the little men well know that they liave but small show to run their herds so long as the heavy outfits are in possession of the range.

If the small man has a little patch of grass saved up for his winter feed, some wandering band of sheep or the cattle belonging to some great company comes along and grazes it off, leaving his few head to winter without any grass. For this reason there are few small uwners today who use the open ranges exclusively. They found out to their entire satisfaction back in the ' 80 s that there was 110 use in a little man trying to hold his own on the open range. Proof of this fact is easily found by a study of the number of sheep and cattle being grazed on the various National Forests. Here the small men are greatly in the majority.

In the beginning the larger men were almost the sole occupants of the ranges in the forests. Under the protection afforded by the Forest Service system in handling the ranges, by means of which each man was given a range and guaranteed exclusive and safe possessioni of it, the little fellows have come to the front very rapidly. On a 11 yoming forest in the first year it was created one man with 60.000 sheep owned 65 per cent of the sheep on the forest. Five years later through reductions made in his herd in order to take care of little men he was running but 15,000 , or about 7 per cent of the total. Meantime, from a dozen men using the range the number has grown to eighty. Is there any sane man who, knowing the conditions, believes that these eighty men would be there today, except for the Federal control of the ranges? Can it be conceived that the great herds would have been voluntarily reduced to meet the 
requirements of new settlers asking for a place on which to graze their stuck?

Nor is the sheep-owner the only sinner in this respect. True, he is one, but the cattlemen have also done considerable work along this line of discouraging the small settlers. Great herds of young steers have been purchased in the southern districts, shipped to the northern ranges and turned loose in a district already stocked with the mixed cattle of the settlers. No efforts were made to hold them on any particular range, but they were allowed to wander at will, the owners depending on their round-ups to find them in the fall. Not only was the range eaten off by these nomadic cattle. but, what was equal!y injurious to the settlers, the presence of the steers prevented the cows from raising anything like a fair percentage of calves, and thus the local men suffered a double loss.

Unfortunately for the plans of this class of men, the manner in which the National Forests are being handled has put the most of them out of business. They depended upon the mountain ranges for their summer feed and as they can obtain only their fair share of that the rest of the range is of little value to them.

Restoring Former Range Conditions.-There is little doubt that under proper care the ranges may be restored to their old values, and the restoration need not be an expensive or a difficult operation. All that Nature asks is time to heal up and cover over the scars left by man's misuse of her bounty.

Given any over-grazed range, no matter how badly it has been abused and either keep the stock off it for a term of years, or reduce the number to a point where 
the grass will not be eaten off each growing and seeding season and Nature will take care of the rest, and, excepting in rare cases, the old grasses and forage plants will return.

Ride along any western railroad whose right-of-way is fenced and note the difference between the range inside the fence and that outside. Naturally there are certain regions where foreign weeds and plants have to a great extent taken the place of the original grasses. It has been demonstrated, however, that the old grasses are their equal in a fight for their rights, if given a chance. The trouble heretofore has been that the grasses were eagerly eaten by the stock, while the weeds were left alone.

There is no doubt another reason: that the old grasses under such heary attacks have lost some of their old strength and powers of reproduction, and that they are not so aggressive as of old. Careful observation has established beyond doubt that with nearly all grasses the continued close-cropping of the plants tends greatly to reduce the vitality and germinative power of the seeds.

In the southwest and on some of the ranges in the northern regions there is a little green weed (Guttierrezia) known locally as snakeweed, fireweed, turpentine weed, and possibly by other names. It has taken large areas of range that were once the pride of the country. It is something that no animal is known to eat, even under the most pressing conditions. It generally grows to a height of ten inches, and is a bushy plant with small yellow flowers. At times the prairies will be yellow with the blossoms and always, at a distance, it looks green and beautiful. 
There is a great area of this weed in eastern Colurado. From La funta west along the Santa lie road one can see from the car windows great sweeps of lovely green prairies which delight the eye. On cluser examination the green is the green of snakeweed, and on acres and acres the grama and buffalo grass that once covered the whole country are gone, with the exception of an occasional struggling bunch. In winter this weed dries

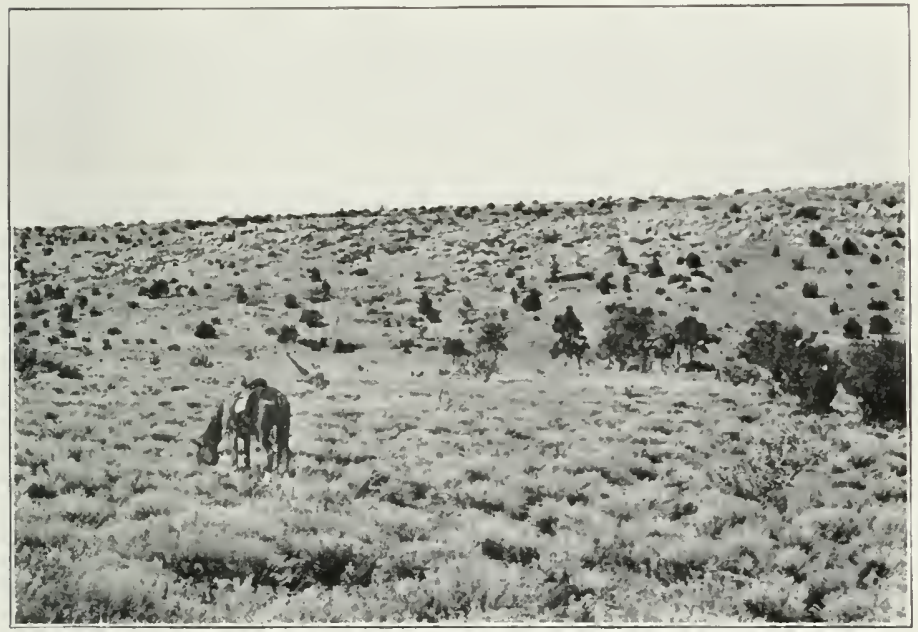

A Range of "Snake" or "Fire" Weed Which Is Sometimes Mistaken for Feed.

and the flowers bear little white seeds that seem to be filled with a resinous substance which makes it burn like tinder. Hence the name fire or turpentine weed.

Botanists tell us that Guttierrezia is a native of the plains region, and only became numerous because $\mathrm{Na}$ ture, finding the other cover all eaten off, this weed naturally took its place. Given any fair show, the grasses will eventually crowd it out. 
That the entire western range has been seriously damaged by over-grazing goes without saying. The only way in which it can ever be restored to anything like its old time condition and value is through some system of range control by a power stronger than any local management. It can only be done by the Federal Government, which is free from entanglements with local users and local prejudices. That it will be done some day is as sure as that the run rises in the east.

One of the most efficient methods for range improvement, that of a "rotation in use" of the ranges, can only be utilized through Government control of the lands. This rotation system when applied withdraws but one-fifth of each range from grazing use each year. This gives the grasses a chance to reseed the land and in a short time the productive capacity of the land is so increased that the one-fifth not used is more than made up by the improvement on the other areas.

In five years the range shows remarkable improvement and with conservative use will hold its value as a stock range.

To allow such a valuable resource to continue to be abused when it can easily be placed on its old footing again is not consistent with American methods. It is, however, the stockmen's problem and they must solve it.

Reseeding a Range.-While the ranges will recover most of their old form and value if given a rest, there are many pastures and enclosed areas where it is possible through artificial means to secure not only a better growth but in some instances a better forage plant than was originally found on the ground.

A great deal of experimental work has been done 

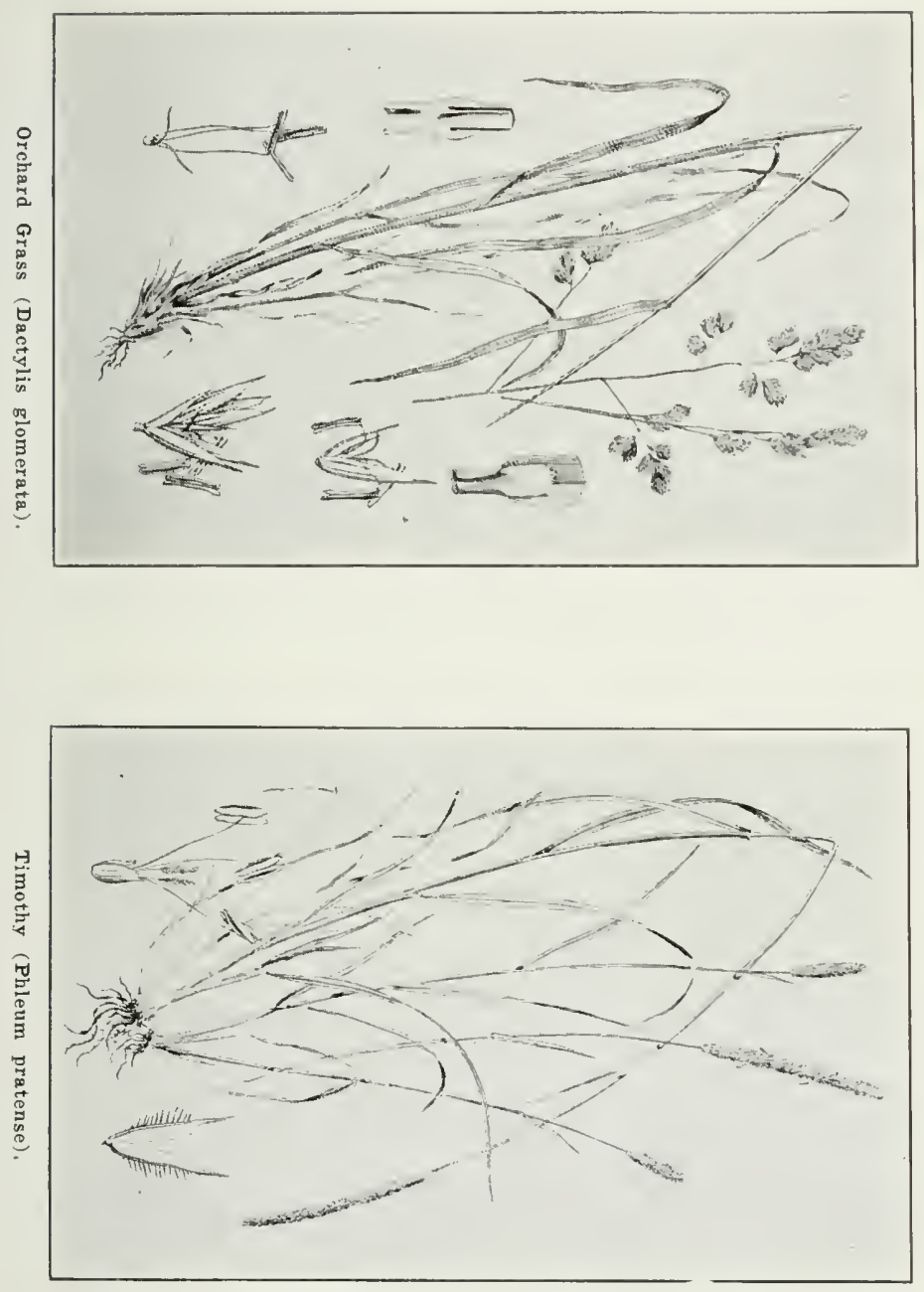


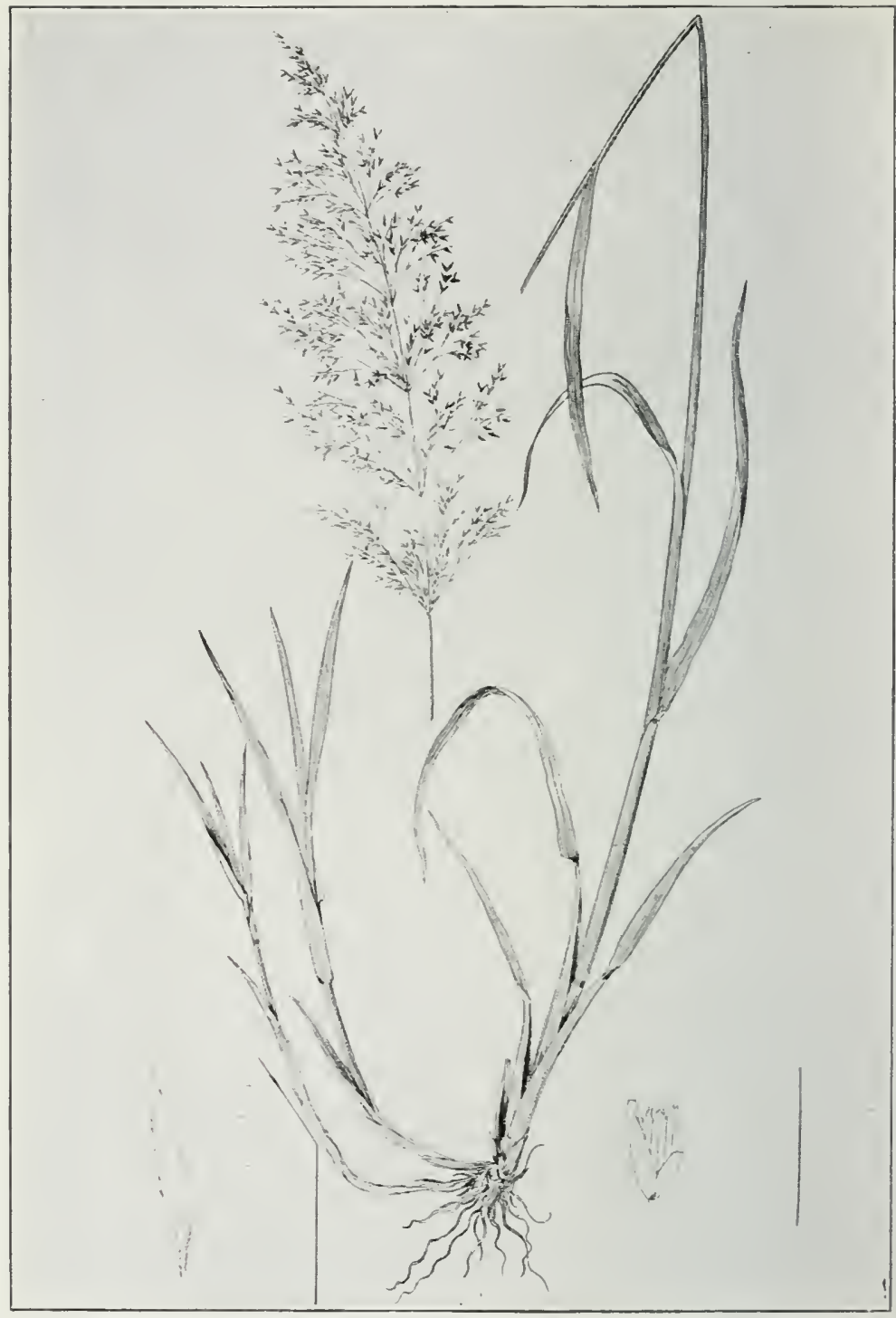

Red Top (Agrostis alba). 


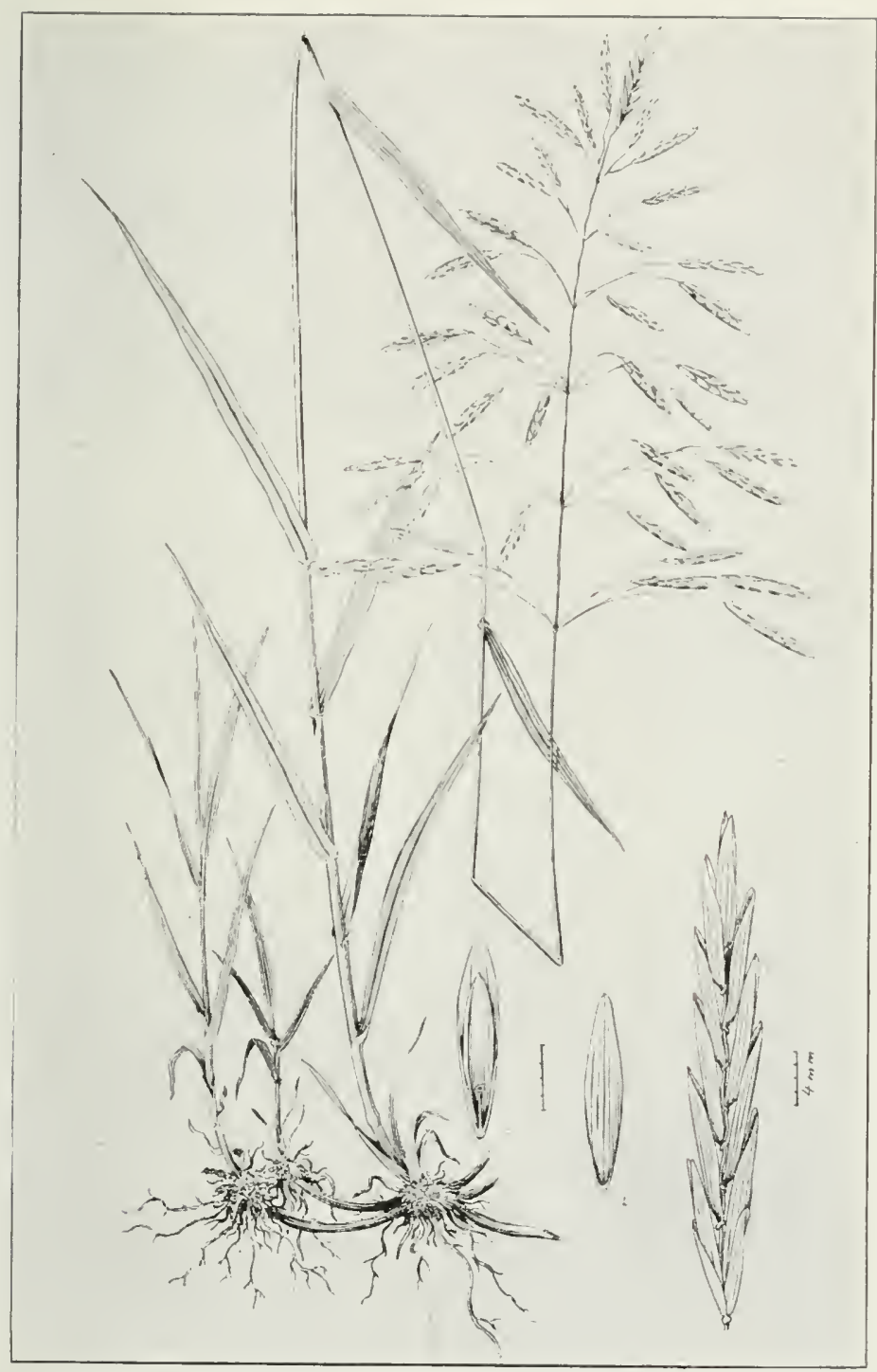

Hungarian Brome Grass (Bromus inermis). 
along these lines by the Federal Government, and out of the mass of data a few solid facts have been developed upon which future operations may be based. Out of a large number of grasses which have been tried on the western ranges but few have been found worthy of general use. For mountan meadows and high ranges where the moisture is sufficient timothy (Phleum pratense) and redtop (Agrustis alba) have done well.

For the lower ranges where the average moisture is low Brome grass (Bromus inemis) and Perennial rye (Lolium perene) have done well, seem to withstand the drouthy conditions and flourish with the native grasses. Orchard grass, however, has been a disappointment in some soils. Where there is sufficient moisture on well-drained soils Kentucky bluegrass (Poa pratense) has given excellent results.

Timothy and redtop both call for a moist rich soil and while timothy will withstand more or less drying out, redtop should never be tried on land that becomes perfectly dry during the summer. The best places for redtop are cienegas or vegas, low swampy spots where there is always some moisture, and even flooding will not injure it. Do not be discouraged if there is no apparent showing for three or four years, as it is a very slow plant to get started, but once fairly seeded down it will last practically forever.

Timothy, on the other hand, starts very easily with a moderate amount of moisture, and soon gains a footing. Its rigor is remarkable and for choking out poisonous plants on meadows it has proved invaluable. It has succeeded admirably at elevations as great as 10,000 feet and is much more drouth resistant than is generally believed. 
Under a general diversity of soils, moisture and range conditions timothy is probably the most satisfactory forage plant for reseeding operations.

Experience has also demonstrated that under average conditions fall sowing is the best. The seed sinks down into the soil with the winter snows and gets the first warm spring sun to start it into life and before the hot summer sun comes has developed a sufficient root system to live. Noreover, there should be a certain amount of work done to get the seed into the ground. This can always be best done in the fall, when the ground is drier than in the spring.

Where the land will allow it, the seed should be harrowed in. The more the ground is stirred, the better. Where a harrow cannot be used a limb of a tree dragged over the land either with a team or at the saddle-horn gives fairly good results.

If available a band of sheep fed over the land a few times also offers a very gond vehicle for the purpose. Where the area is large and the time limited excellent results have been obtained by sowing the seed on the backs of sheep as they lay in the bed ground and then grazing them over the area for several days. The seeds drop out of the wool and are tramped into the ground by the feet of the animals.

Where it can be done the dividing of the pasture into two or more tracts, and keeping stock off for the growing season, gives the plants an opportunity to get a fair start, and after that they will take care of themselves, if not too heavily grazed. Of either of these seeds sow not less than ten pounds to the acre, and preferably fifteen. The more the better. Be sure to get the seed true to its name. Again, also be sure to test it for 
vitality. This is easily done at home by taking a shallow tin pan like a milk pan and placing an inch of clean sand in the bottom. Wet the sand and in it plant any number of counted seeds. Cover it with a wet cloth and set in the sun or some warm place and see how many seeds sprout. One can very easily get a close estimate of its vitality. Seed that will not show a per cent above 70 is not of first-class grade.

Overgrazing vs. Close Grazing.-One of the most difficult things which the forest officer is called on to determine is whether or not a certain range is being overgrazed or overstocked. In such cases the best possible key to the situation is the condition of the stock. An overstocked or over-grazed range and fat cattle or sheep cannot be found in one and the same place.

If the stock is fat and in good condition at the close of the season, it is safe to say that the range is not over-stocked, for that season at least. If the season is an abnormal one, with more than the usual average precipitation and plant growth, then an allowance must be made to make a fair average for a series of years.

On the other hand, a range may be over-grazed through having such a number of stock upon it at all times that the plants are given no opportunity to get their full development. Plants must not only obtain food from the soil but from the air, and if kept eaten down continually their growth is weakened, their vitality lowered and they not only die out, but what food they do furnish lacks the necessary fat-producing qualities. This is best illustrated by considering an ordinary meadow. After the crop has been mowed there is nothing left but the short stubble, and if one judged by that one might say the field had been injured. But 
the plants had been given a full chance to develop, so that not only was the crop a first-class feed product but the roots had stored away sufficicnt vital forces to enable them to reproduce themselves another season.

So with the grazing side of this question. If the number of stock upon a range during the growing season has been so many as to keep the plants constantly grazed down, so that the leaves and stems could neither develop nor obtain from the air the elements necessary not only to make food but to enable the plant to perpetuate itself, then it lias been over-grazed. Fat stock will not be found on such a range. But if the stock have been handled right, the plants given a chance to grow, though the ground may show very little grass above the stubble in the fall, yet it has not been overgrazed in such a way as to injure it.

All over the West one may see good examples of this sort of over-grazing. Alfalfa, one of the most persistent forage plants known, has often been completely killed out by constantly keeping stock on the field in such numbers that the green shoots were nipped off as fast as they appeared above the ground. Thus the plants did not derive any food from the sun and air, their vitality was lowered, the roots were weakened and they finally die-simply starved to death. Then the farmer declares his alfalfa has "run out," takes his harrow and rips up the surface of the ground, lets the light in on the roots, scatters a little fresh seed over the worst places and keeps his stock off it a while and soon has his field as good as ever. 


\section{CHAPTER XIII.}

\section{POISONOUS PLANTS.}

The losses to the stockmen using the western ranges through poisonous and injurious plants amount to an immense sum each year. Some of the losses are unavoidable, some can be minimized, and others may be almost entirely done away with.

These losses are due to two causes, the first may be called mechanical, and is not due to the poison in the plant but to the effect upon the animal through other means. Under this head come bloat, death from corn smut, also from foxtail (Hordeum), Porcupine grass (Stipa), and needle grass (Aristida), whose sharppointed awns work their way into the lining of the mouth, lips, eyes and nostrils, causing festering sores, frequently becoming so bad as to cause the death of the animal through starvation. In corn smut the dry spores expand through the action of the liquid in the stomach and obstruct its operation.

The second cause is the poison contained in the various plants. In considering this subject it is generally assumed by the average stockman that most animals have a keen sense of danger in seeking their feed. and can almost unerringly select the harmless plants from the injurious ones.

To a certain extent this may be true. If the animals are surrounded with plenty of feed from which to 
choose they will generally leave the injurious plants alone, excepting possibly the lupines. This, however, seems due more to a possibility that the injurious plants are not so palatable as others. So long as the animal is not too hungry it will content itself with selections from the best, but when hungry and on an over-grazed range, it seems to turn to the injurious plants as second choice, eating them with apparent relish.

To prove this it is only necessary to point to the experience of almost every shcepman in the IVest who has had losses from injurious plants. In a large number of cases the poisoned animals have either been driven through a section where feed was scarce or hurried on long, hard drives and then allowed to graze a range containing inferior feed and plentiful poisonous plants. Under such conditions the ability of the animals to distinguish between the good and bad either by sight or smell seems to be at fault, or else is disregarded because of hunger.

Another frequent cause of losses is when sheep, having been shipped on the cars, are unloaded and driven out on a strange range for feed or water. Whether they are unusually hungry or not used to the range, if there are any poisonous plants on it losses are certain to follow. Some plants like death camas are so similar to grass in their earlier growth that stock cannot distinguish them from grass and are eaten unknowingly.

It is therefore safe to presume that taste and smell and possibly siglit have comparatively little to do with animals avoiding poisonous plants. If it is due to anything it is to that indefinable sense in animals called instinct.

Under ordinary conditions sheep will not touch the 
leaves of the choke cherry (Prunus demissa), yet when driven over hard trails where feed was scarce and then through thickets of that shrub they have eaten the leaves greedily and died in great numbers.

Herders Should Be Posted.-It would therefore seem that every herder in charge of stock and especially sheep should be posted as to the different poisonous or dangerous plants with a view to avoiding as much as possible such accidents. There are but a few really dangerous plants and if lierders knew them by sight much loss could be avoided.

Some plants seem to be more dangerous after heavy rains or dews than at other times. This may be ascribable to the fact that the ground is soft and the animals in pulling at the stalks pull up the roots also. It has heretofore been accepted as a fact that the root of the low or purple larkspur contains the poisonous property, but careful experiments have proved this an error, for the roots have been fed to cattle in both large and small quantities without any injurious effect whatever.

It is also a very difficult matter to pull up the roots even when the ground is soft-so difficult, in fact, that no steer could possibly obtain much of it. Others like the lupines seem to be perfectly safe when the plant is young and only dangerous when ripe. On the other hand. several rarieties, the larkspur and the camas seem to be harmless, or possibly unpalatable and are not eaten by the animals, after they have reached more or less full growth.

On these ranges the matter can be handled by simply keeping the stock off the poisonous areas until the danger is past. This cannot always be done with cattle and horses but may be done with sheep. 
Remedies. - A common practice among western stockmen, cowboys and others when animals are poisoned, is to keep them continually moving. It is doubtful whether this can be called a safe thing to do in many cases, while in some it is a positive injury.

Generally speaking the best thing to do with such animals is to let them move about or lie still as they please. Bleeding is another famous "rough and ready" remedy which should be more honored in the breach than the observance. The sins that have been committed against poor, weak, helpless animals by bleeding them are too numerous to mention. liew cases of poisoning in animals of any kind can be helped in this manner.

There are several handy remedies which stockmen usually try when remedial agents are necessary. The commonest is grease, either hot lard, melted bacon or oils of various sorts. These given either as injections or drenches are excellent in most cases of poisoning. They furnish a coating for the lining of the stomach and intestines, assist in movements of the bowels and aid in eliminating the poison from the animal's stomach.

Baking soda (bicarbonate of soda) is another handy remedy which is given where the poison is supposed to contain an unusual amount of acid, while vinegar is freely used for alkaloid poisons. I have seen stockmen give both to an animal at the same time and as one in a way neutralizes the other the result would seem to be bad for the animal. Lard and grease are also of value in the early stages of bloat. Nature is assisted by them in removing through the bowels the load of fermenting food which makes the bloated condition. 
In cases of paralysis through poison the injection of hypodermic doses of strychnine together with alcoholic or other stimulants to control the symptonfís of paralysis is often used with excellent results. On the other hand, where the pain is intense, as in hemlock poisoning, doses of morphine or chloral are successful. Strychnine is also the most satisfactory remedy known for loco in cattle. For horses suffering from loco Fowler's Solution in half-ounce doses in either drinking water or feed is successful.

Permanganate of Potash.-In the large majority of cases where animals have been poisoned by plants the use of permanganate of potash offers the most satisfactory remedy known to medical science. It is easily applied, easily carried in packs or wagons and should be kept in every camp and stockman's cabin. It may be given direct as a drench or as an injection through the wall of the stomach. The drench is, of course, the easier method. It does not affect the general condition of the animal. What it does do is to get at the poison lying in the stomach and intestines and not already taken up in the system and through its well known chemical properties attack the poisonous alkaloids, rendering them harmless.

In preparing the drench of permanganate of potash for sheep take equal amounts of permanganate of potash and sulphate of aluminum, five to ten grains of each, and dissolve in water. Pulverizing before placing in the water will get better results. See that all is taken up in the water, as the raw salts are very injurious to the lining of mouth and throat. For lambs use about three grains each; for horses fifteen to twenty grains: for cattle thirty to fifty grains. 
If there are a great number of animals to be drenched the mixture can be made according to this scale in large quantities and given on the basis of a pint of water to each dose. A drench is best given through a horn, as there is no danger of its being broken as a bottle may be. Set a sheep up to give a drench but larger animals must of course be thrown. Never drench an animal through the nostrils. Think how it hurts to get liquids in one's own nose. A gentle horse may be tied to a high post so that his head is at the right angle, taking care not to have the rope tied hard and fast, lest the animal cast itself in struggling and cloke before it can be relieved.

A cow, if lying down, should have her head set up on the horns, or, if standing, handle her much as directed in the case of a horse. Slip the drenching instrument into the mouth, taking care that it is not allowed to get between the grinclers and, if a bottle, be broken. Allow the liquid to slowly find its way down the throat. Give time for the animal to swallow, remembering it is a case of forcing and that it will be likely to put off swallowing as long as it can.

Poisons Do Not Affect All Animals Alike.-Stockmen have often been puzzled over the way in which animals in the same herd and subjected to the same conditions are affected by poisonous plants. With sheep this is quite noticeable. Out of a herd of sheep many will die at once; others linger along and recover, and some do not appear to be troubled at all. This, in ruminants, generally is due to the condition of the animal's stomach.

As few poisons can injuriously affect an animal until taken into its system, if the stomach is full the progress of the poisonous matter is slow and may be all neutral- 
ized by the amount of feed in the stomach. On the other hand, if the stomach is empty, it enters the circulation at once, the animal is soon affected by the poison and remedial measures are seldom in time.

Bloat.-As bloat is not the result of a poison it comes immediately under the head of mechanically dangerous plants. It is confined principally to alfalfa, although all the legumes, like red and white clover, will cause bloat in stock when eaten under certain conditions. There are several range plants which will do this. Cattle eating large quantities of lupines after heavy rains or when wet with heavy dews have been known to bloat and die, but stockmen's losses from bloat in the West are almost wholly confined to the feeding of alfalfa.

Generally speaking, the dangerous time is when the alfalfa is from three to eight inches in height, and also when wet with heavy dews or recent rains. The usual method of handling it in the early spring is to sow among the plants some seed like oats or barley. This springs up with the alfalfa and is cropped with the latter as the stock grazes, thus keeping the stomach from becoming solid with the gas producing plant.

Bloat is simply the gas produced from fermenting feed, which gradually crowds the stomach and other organs forward until the action of the heart and lungs is seriously interfered with. The work of the gas may readily be noted by standing behind the animal. The left side of the body will be seen to protrude several inches farther than the right, forming a huge lump just back of the ribs and making the animal appear decidedly "lop-sided." This is the distended stomach pressing against the hide of the animal.

Old alfalfa-raised cows fecling the pressure coming 
on will go to the irrigating ditches and stand with their front feet high up on the bank of the ditch and their hind feet in the water, thus allowing the stomach to drop back and relieve the pressure on the other organs. They will groan and grunt at a great rate, showing they are feeling far from comfortable, and animals in this condition should be carefully watched.

I have known a ditch to break and allow the water to run unnoticed all night long on the alfalfa where a hundred fine four-year-old steers were grazing. The effect of the water on the alfalfa was so prompt that in less than twelve hours fifty of the animals were dead from bloat. There is no such thing as the animal becoming immune in any sense of the word.

Nor is the bloat due wholly to green feed. I have known a bunch of fifty yearlings put into a feed yard over night and fed on dry alfalfa hay and in the morning ten of them were dead from bloat. Milk cows, fed all their lives on the hay, have been killed from eating alfalfa. Investigation of many such cases shows that generally death resulted from eating hay coming from the first cutting, and also that the animals had eaten unusually large amounts of the fine leaves.

Sheep, although subject to bloat, do not seem to be so easily affected as cattle, and the loss among sheep from this trouble is comparatively slight. Horses and hogs do not appear to bloat from either green or cured alfalfa.

As a general thing, cattle grazing upon alfalfa fields should always be carefully watched, especially in the early spring, when the plant is just starting to grow. When the trouble reaches a certain point immediate action is necessary or the animal is beyond help. The 
gas pressure against the heart and lungs simply stops the breath, and it is but a matter of seconds if the animal is to be saved.

Various remedial methods are practiced among stockmen to aid the animal. Baking soda (bicarbonate of sodium) is frequently used as drench in the early stages, but its value is somewhat doubtful. Shoving a piece of garden hose down the animal's throat is also a common expedient. This opens up the throat and stomach and allows the gas to escape. Many stockmen will tie a "bit" composed of a piece of hoe or shovel handle about eight inches long into the animal's jaws. This keeps the jaws open and allows some of the gas to escape.

Some stockmen, seeing a tendency to bloat among a bunch of cattle, will go into the fields on good horses and with whips run the animals about the field for half an hour. If the trouble has not gone too far this will often bring relief.

The one certain remedy for bloat is what is known among stockmen as "paunching" or "rumenotomy." If you will notice the old milk cows in an alfalfa growing region, you will see just below the left hip bone and about four inches back from the last small rib a number of scars. Sometimes you will see an open wound, and if you happen along when the animal coughs you may see a thin stream of green half-digested alfalfa spurt from the wound. This is the result of "paunching." The stream of alfalfa is forced out of the stomach by the cough through a wound not yet healed.

Whenever it is necessary to perform this surgical operation there is little time in which to speculate and study up on the proper methods. "Do it now" is eminently applicable to this affair, for every second counts. 
This is especially true if the animal is down on its side. There is no prenunitory sign or long-drawn-out death struggle. The breath stops and the animal is dead.

If you have a trocar and cantula nse it; if 110t, take a pocket knife, for there is not time to go to the house for the former. I trocar and cannla is a long. sharp, steel instrument similar to an ice pick. It has a metal scabbard over it and when plunged into the animal's side the tool itself is withdrawn, learing the scabbard or canula in the wound through which the gas may escape. I have heard of using the long sharp nose of an ordinary oil can. finec through the hide and stumach and then unscrew the can and leave the point iil place.

Select a spot five inches below the hip bone on the left side and about as far back from the last small ribs. Ilere the hide and the wall of the stomach come close together. Into it plunge the instrument or knife blade. Don't be afraid to do it boldly. for you have a thick hide to penetrate and also the stomach lining. Look out that the knife blade does not close up on your fingers and make a nasty cut. Also keep your mouth closed and head away from the line of the cut, in order to aroid receiving at short range some of the contents of the stomach in the way of gas together with a goodly amount of half-digested alfalfa.

In some cases it nuy be necessary to open the stomach and remove the contents, but this is not often. The gas rushes out of the cut from the stomach and the animal is immediately relieved, as a man would be if some one had him by the throat and suddenly released him. Smear a little grease or tar about the cut to keep out flies and screw worms; sew it up with a stitch or 
two if you wish, and the place soon heals over. In the majority of cases the application of pine tar or grease is all that is necessary.

Loco.- While the annual losses from the loco plant may not foot up as much as from some others, it is believed that in this respect it stands well towards the head of the list. Certainly it is more in the public eye than any other single poisonous plant in the whole IVest. The loco plant is found generally over the entire Rocky Mountain region. Extend the eastern boundary line of the states of Montana and Myoming directly south till it touches the Rio Grande river, and you have about the center of the area corered" by the plant. making a strip some 600 miles wide and extending from the Canadian to the Mexican borders.

Loco is found everywhere. It is most common on the open prairies but grows plentifully in the mountains where the elevation does not appear to make any particular difference in its growth. There are many varieties of the plant, as well as several other plants mistakenly called loco. However, the fact has been very well establisherl that there are but two species which are generally called loco. These are aragallus lamberti, and astragalus mollissimus. Of the two the former is the most widely distributed and is responsible for most of the damage to stock. Both have flowers of various hues, ranging from deep violet to rich purple. not unlike those of the common sweet pea.

In aragallus lamberti, the plants growing on the prairies are frequently a beautiful creamy white, while in the mountains the darker colors are more prominent. In places the loco grows in great patches and to the uninitiated looks like a field of alfalfa. On the plains 


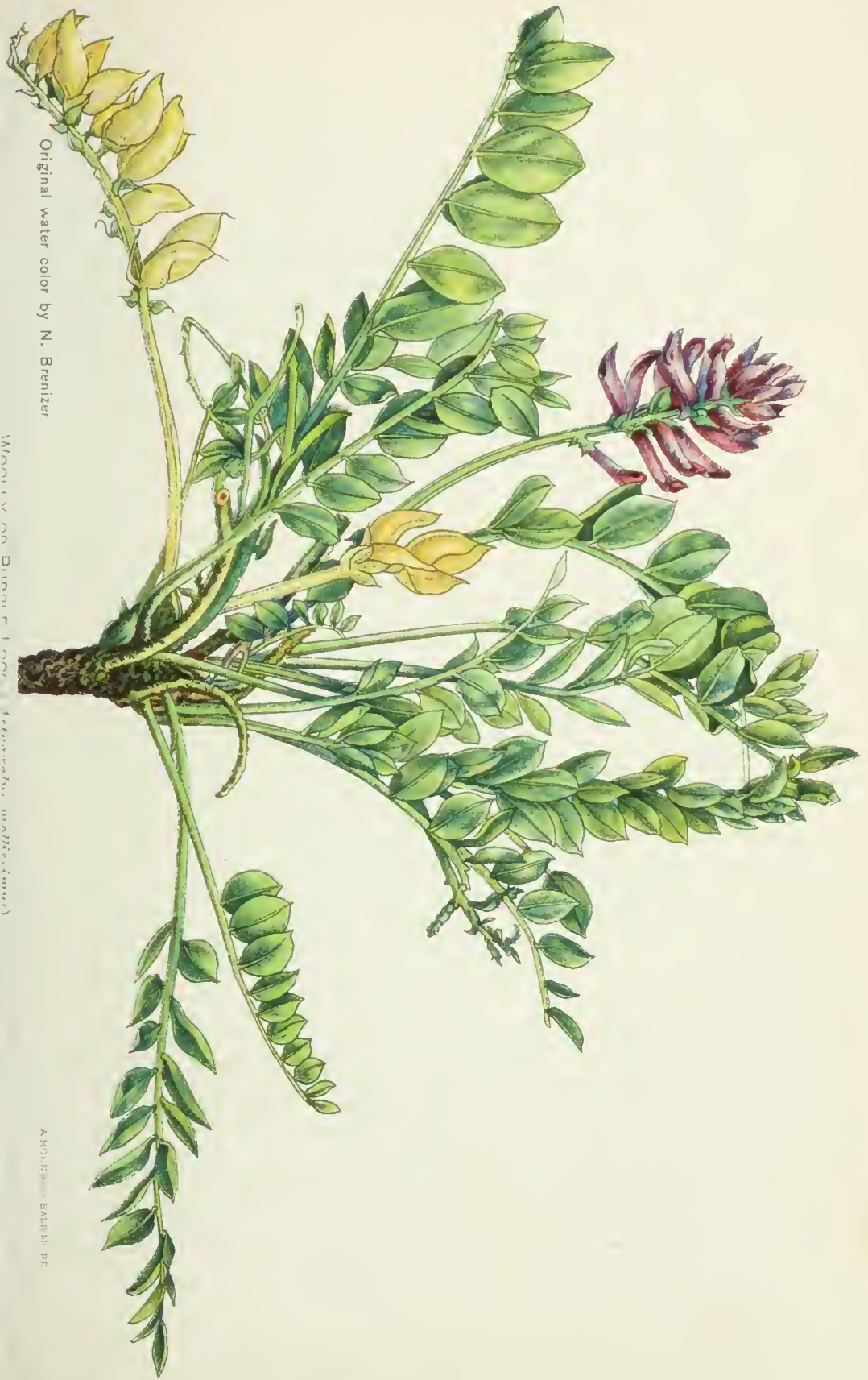





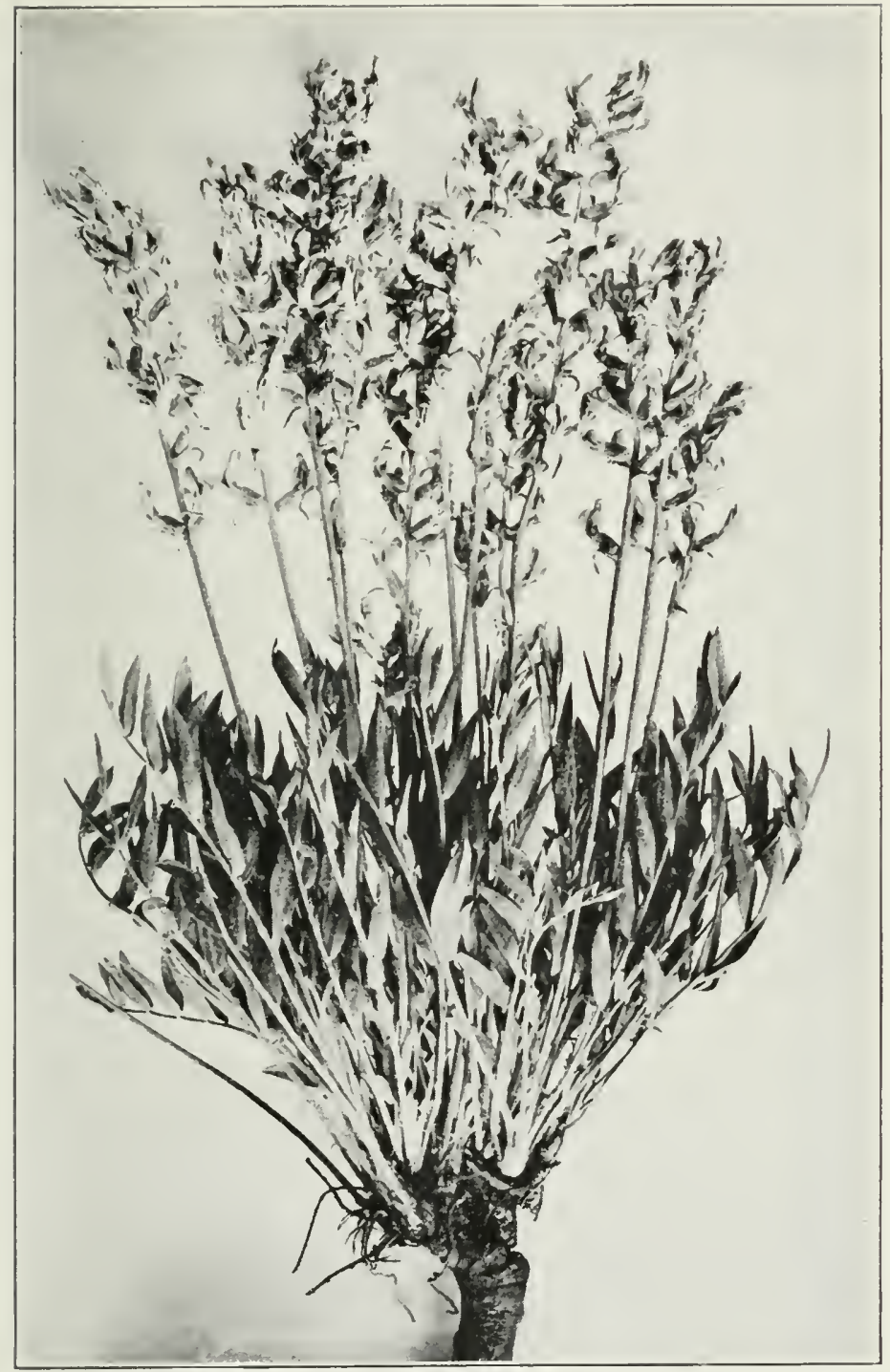

White Loco or Rattle Weed in Flower (Aragallus lamberti). 
east of Albuquerque, N. M., in May, 1912, loco was so plentiful that the brilliant coloring of its blossoms could be seen with the naked eye for three or four miles. the patches often covering 100 acres in one solid bed of color. It is also a well established fact that loco is not plentiful every year but seems to come in for a season and then not be heard from for several years. Every western stockman knows that a wet spring or winter will be followed by a bad loco year. For this reason it

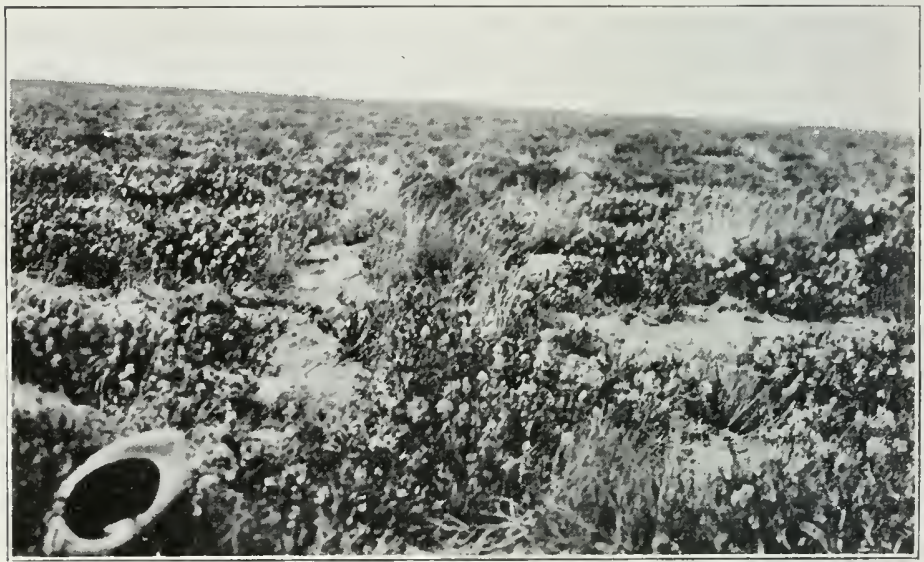

Loco on the Range Near Albuquerque, N. M.

is presumed that the seeds in order to germinate require an unusual amount of moisture.

For many years scientists investigating losses from loco asserted that the plant contained no apparently injurious matter and that the loco effect must come from other causes. But this was received by stockmen with little credence; they simply pointed to the afflicted animals and showed the undoubted connection between the eating of the loco and the serious condition of the 
animals soon after. However, the matter has recently been carefully investigated by the Lnited States Department of Agriculture, with the result that the poison in the plant has been separated and identified, and following this remedies have been tried which have resulted in complete cures of amimals bally locoed, leaving 110 injurious after effects. Thus the contentions of the practical stockmen have been completely sustained by the scientific investigators.

IVhile the eating of loco is found to affect horses, cattle, sheep and goats, it is among horses that the most damage is done. It is only occasionally that there is what is known as a "loco year," during which sheep and cattle die from eating it. But horses die every year when the plant is plentiful. This I have always accounted for by the fact that the horse is not a bruwsing animal. The green loco appeals more to him in the early spring when there is little green feed than to the other stuck which, being browsing animals, find in the young buds of the trees and shrubs and the weed growth something to take the place of the loco.

The spring of 1888 was a bad loco season in northern Arizona, and thousands of locoed horses and cattle died. The winter previous was unusually wet. with heary rains in the early spring, and long before the first shoots of young grass showed above the ground the loco was spreading its beautiful growth all over the ranges.

One peculiarity of the losses among the cattle was that the better grades, the imported stock, were more easily affected than the common scrubs. W' hether this was due to the superior instinct of the western-raised animal cannot of course be proved. but it is not very 
probable that it had much to do with it. In my opinion the westerners were tougher and more able to stand the effects.

Seven years later there was another bad loco year, but that time it was almost entirely among horses. This was also the case in an outbreak in northern New Mexico in 1906, when so many horses died in some districts that the spring round-ups had to be abandoned because "everybody was afoot," as the cowmen put it.

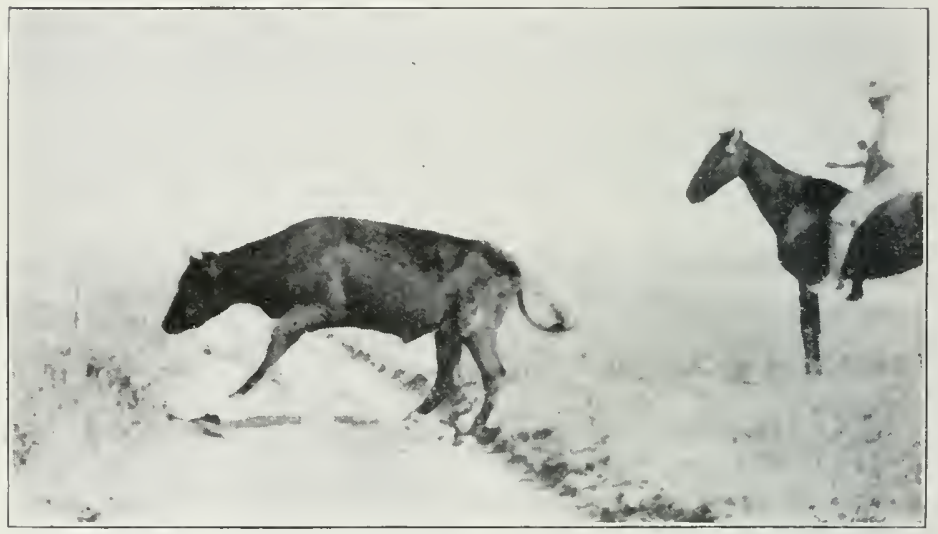

A Locoed Animal Will Step High Over Anything-Even a Rope or a Trail.

The round-up work could not be taken up until fall, and a new lot of ponies had been shipped in from other ranges where loco had not made its appearance. I Tet in spite of the losses among horses practically no cattle died from it that year.

Loco Symptoms.-The symptoms of loco poisoning are so well known that it hardly seens necessary to repeat them here. The animal loses flesh, every hair on its body seems to have turned the wrong way, its eyes 
are staring and sunken and the gait luecomes wablyly and uncertain. In cattle a commons symptom is the formation of a serous sack nuder the jaws, often langing down like a great puch. The eyesight appears to be affected because the animal will "step high" over a simple rut or wagon track in the road or a rope or even a twig on the ground. Locoed horses often cannot be led through a gate, lout must be turned round and

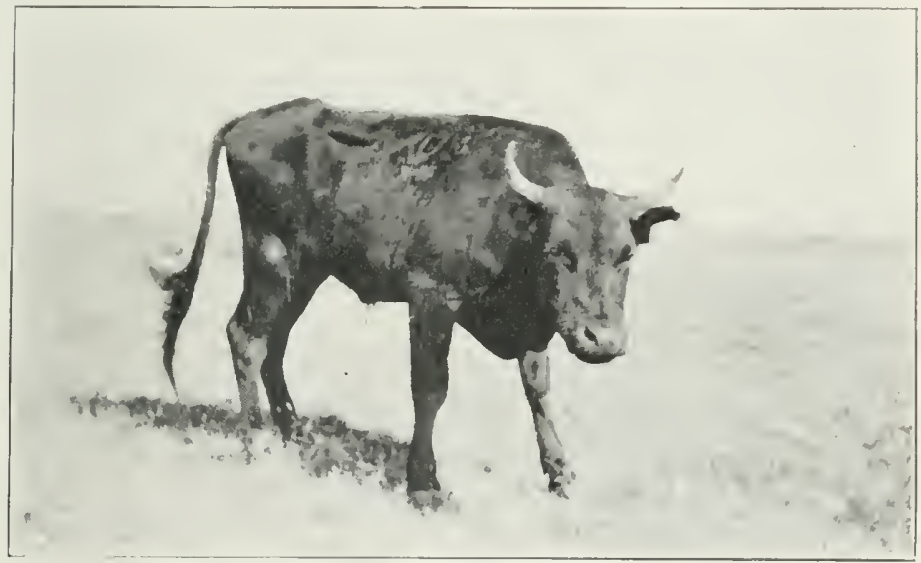

A Typical Locoed Animal.

forced through backwards. Igain they cannot be backed excepting by the most riolent efforts, but if once they start back nothing but a mountain can stop them. I once saw a locoed mule driven by an Irishman who had never heard of loco. The animal was attached to a dump cart and was being backed up to a cliff over which the refuse of a military post was being dumped. On the edge of the cliff a log twelve inches thick was fastened as a bumper against which to back the wheels 
of the carts. It took the driver some time to get the mule to back, but when, after a lot of profanity and fighting, the poor animal decided to do what was wanted he did so with so much enthusiasm that when the wheels struck the $\log$ they went over it as if it were a straw, and with the Irishman swinging to the bit the outfit dropped over the cliff where, a hundred feet below, it still lies among the rocks. The driver hung on until he saw it was useless, and then let go just in time to save himself from a like fate.

One of the very best and toughest cow ponies I ever owned was a locoed horse that could not be led two feet by the bridle reins. The only possible way to handle him was to get him ahead and drive or herd him along. Is for getting him across a rope laid on the ground, I believe that if a rope had been laid on the ground in a complete circle around him he would have starved to death before passing over it. Running him at full speed after a cow he was apt at any time to jump three fect into the air to clear some inoffensive little white stick lying on the ground.

Locoed animals seem inclined to fall very readily, especially when drinking. I) wing the outbreak in Arizona in 1895 we were forced to keep men at a strean where many horses were watering to drag out those that fell into the creek or else have them drown in two feet of water. In spite of this many of those that came to water at night were drowned. I have seen large numbers of dead horses lying about the edge of a prairie lake which did not have have more than two feet of water in its deepest place.

Loco-eating is a developed habit. The animal begins to nibble at it probably because other foed is scarce and 
it looks fresh and inviting. Gradually the desire for it takes possession of the brutes until they seem to crave it to the exclusion of all other feed. A locoed cow will hurry over the range from one plant to the next, eating in a feverish haste, and showing not the least desire to touch grass or other forage, so long as there is a bit of loco to be found.

Remedies.-The loco plant rnay be eradicated from pastures by simply cutting it off under the ground or pulling it up by the roots like any other weed. There has been a general belief all over the West that loco grows up again from the roots and if a single shoot of it is left in the ground it will inmediately reproduce itself from that bit. This has been found to be an error. The plant reproduces from both roots and the sced but the growth is from the crown of the root, and therefore if the root is cut off below the crown and before the ripening of the seeds it will not grow again.

Of course on the open ranges, under the present methods of handling the grazing lands, no attempts at eradication will be made, but if the day ever comes when the open grazing lands are handled by the Federal Government, much as they are now managed on the National Forests, loco will doubtless be eradicated from the ranges on some mutual agreement between the user and the Government. The excellent work of Prof. C. D. Marsh of the Bureau of Plant Industry, who has for several years made a close study of loco right in the field where it grows, proves beyond doubt that there is a remedy, and that animals taken in time may be almost if not entirely cured. The only question is the one of handling the animals. If they are gentle and can be given the remedies, they can be cured. With 
range stock, however, the administering of the remedies is almost an impossibility, except at a prohibitive cost in time and labor. The remedies used by Prof. Marsh and the manner of administering them are given at the end of this chapter under the general head of remedies.

Larkspur (Delphinium).-This plant probably comes next to loco in its ravages among stockmen's herds. The losses are confined almost entirely to cattle, sheep seldom or never touching the plant. For this reason a range when it is abundant may safely be grazed by sheep and need not be abandoned because of Larkspur. It is found all over the western region, growing in the open park-like places of the foothills and mountain ranges. There are several species, and according to the best authorities the genus is not well divided, and needs study and revision. All of the various kinds should, however, be considered suspicious. The principal species are tall larkspur (Delphinium glaucum) and purple larkspur (bicolor).

Tall larkspur grows to a height of from three to six feet. In its early growth it is frequently mistaken for wild geranium (Geranium viscosissimum). It is also classed as aconite (Aconitum columbianum). It can be easily identified by the leaves, those of the larkspur being almost perfectly smooth, while those of the geranium are more or less hairy.

Purple larkspur seldom grows to a height of over ten inches. It bears a lovely purple blossom. The difference in size, together with the color of the blossom, affords a ready means of distinguishing between the two plants. The flowers of the tall larkspur are blue. Before they blossom the larkspurs may be mistaken for red false mallow (Malvastrum coccineum), but the 


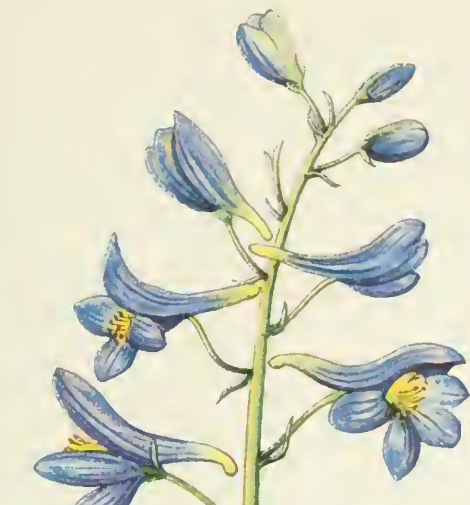

PURPLE LARKSPUR (Delphinum bicolor) 

bright red blossoms of the latter when in bloom furnish a certain means of identification. The plant is generally dangerous when young and tender, and cattle seldom touch it after it has reached its blossoming time. Sheep have been fed the dried as well as green leaves for several days with no apparent ill effects. Extracts from the dried leaves, however, proved fatal. So far as is known no definite feeding experiments have been made with cattle, but the Department of Agriculture is now planning a careful study of this plant which when completed will give some more definite information about it.

The larkspur may be dug up with little trouble, and if it is not widely distributed or very numerous it could be eventually eliminated from a range by using the ordinary weeding tools sold for that purpose. Where it exists in large patches it is thought possible to choke it out with certain grasses like orchard and brome grass. No very satisfactory experiments have yet been made along these lines, however.

Lupines (Lupinus).-The extent of the country over which this plant is found makes it one of the most injurious of all the poisonous plants. Practically it grows all over the WTest and at all elevations. Eaten at certain times and under certain conditions it is extremely injurious to horses, cattle and sheep. The common name among stockmen is wild pea, blue pea, blue bean and peavine. It is often mistaken for a variety of loco, especially the silvery loco (Aragallus splendens), but the leaves offer an easy means of identification. The leaf of the lupine is compound and is attached to the end of the stem, while the leaf of loco is long and feathery with the parts attached to the stem along each side of it. (See frontispiece.) 
The lupines are found in the mountain valleys and hay meadows, and are cut for hay in large quantities all over the western country, making an excellent grade of hay that is relished by all classes of stock. But the feeding of it has been attended with disastrous results, especially in the case of sheep. A careful study of the subject has proved beyond reasonable doubt that the poisonous matter is contained in the ripe seeds. Hence if the lupine can be cut for hay either before the seed pods have fully formed and ripened or after they have ripened and the pods have opened and dropped the dangerous seeds, there is no injury from feeding it. When the plant is young it is eaten without bad effect and is eagerly sought by all kinds of stock.

There are several different lupines and all should be considered under suspicion when the seed is ripe. Owing to its extensive growth there is little hope of eliminating the lupine through its destruction or by sowing seeds of other forage plants, as it is very tenacious and will hold its own against them under ordinary range conditions.

Death Camas (Zygadenus venenosus.)-This plant, sometimes erroneously called lobelia, is found only in Montana, Idaho, South Dakota, eastern Oregon, Washington, northern California and parts of Utah. In these regions it is the most destructive plant that grows. It is injurious to all stock, but more especially sheep. In the early spring its leaves are so much like the leaves of the young grasses that stock presumably is unable to recognize it. The poisonous matter seems to be as great in the leaves as in the roots, hence it is almost impossible to guard against its being eaten excepting by herding stock away from well-known infested areas. 


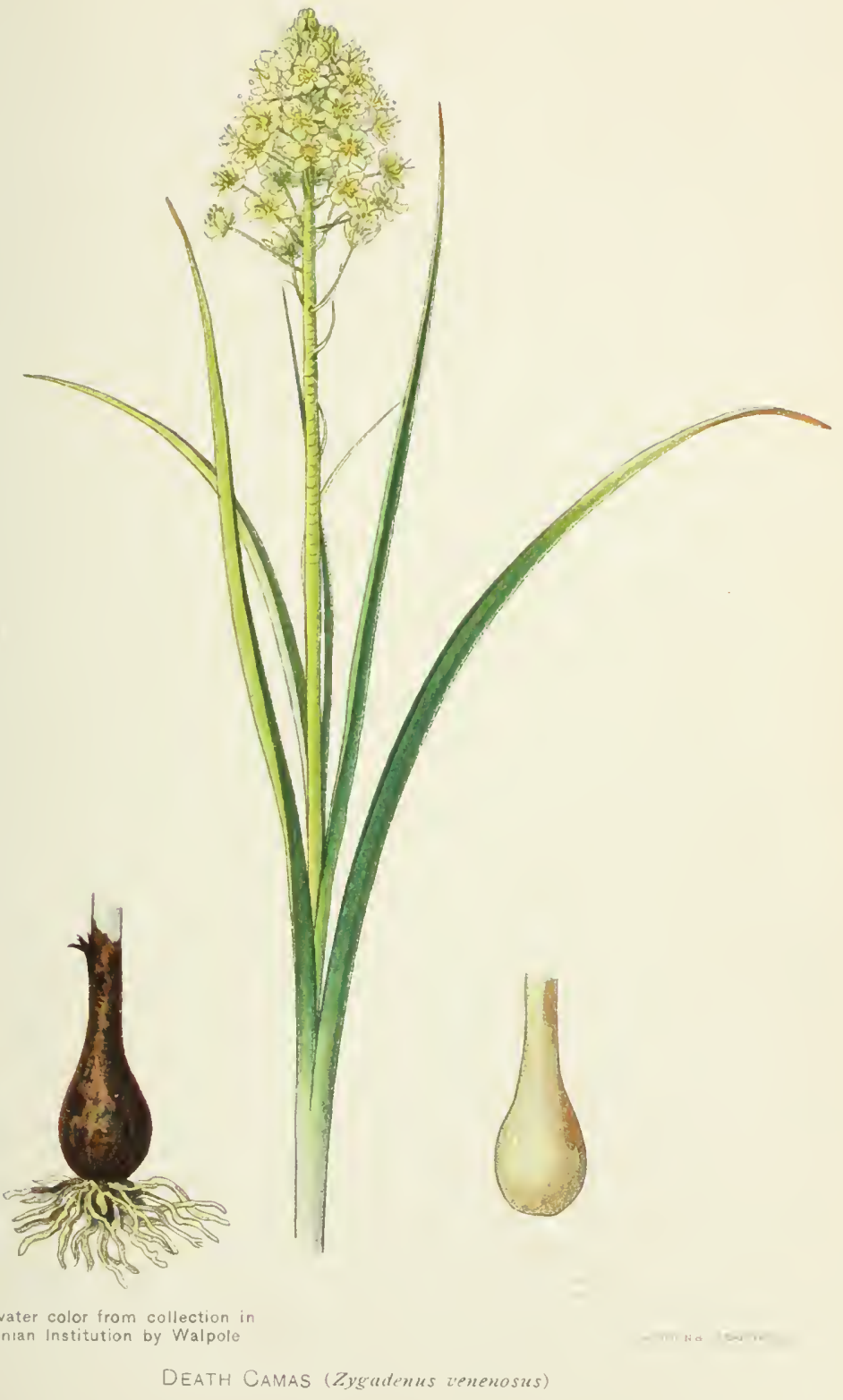






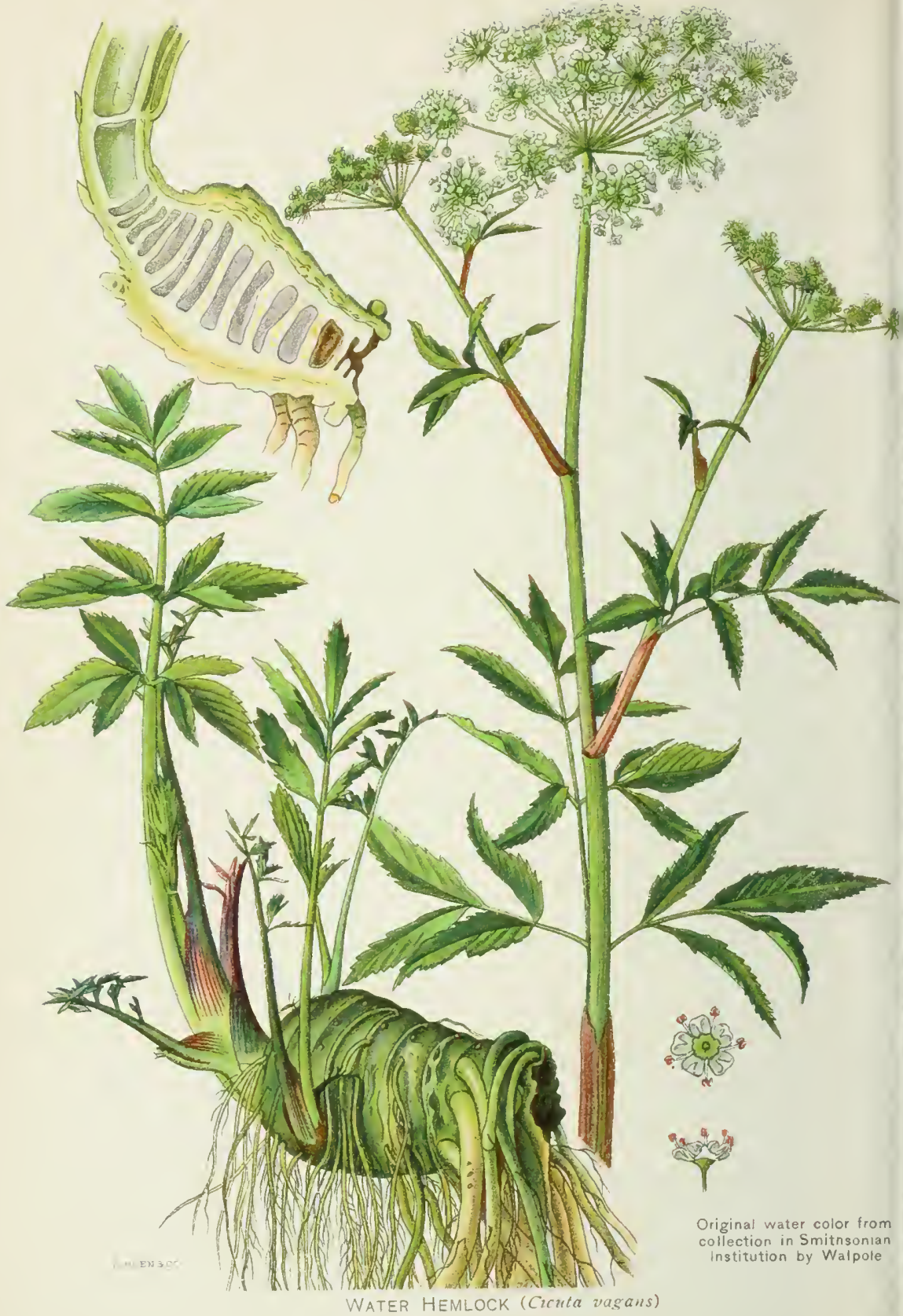


The great distribution of the plant makes this difficult, although the sheepmen knowing the more dangerous places can protect themselves to certain extent.

The plant grows abundantly in the shallow foothill valleys and in the mountains, although it does not flourish in the wet, swampy places. It is often called "wild onion," and at certain periods of its growth resembles a young onion plant. The flower is a greenishyellow. There is a variety of the camas known as swamp camas (Zygadenus elegans), which grows exclusively in swampy places. It is much coarser in growth and leaf than the death camas, but appears to have all the poisonous properties of the other plant. Fortunately it is not so widely distributed and, owing to its coarse growth, is not eaten with the other grasses, as is the death camas.

\section{Water Hemlock (Cicuta occidentalis, C. maculata.-} This plant sometimes is called cowbane or wild parsnip. It is a smooth perennial from two to five feet in height. with several slender tapering roots in a cluster at the base of the main stem. The similarity of the roots to the ordinary parsnip accounts for the term "wild parsnip." The leaves are doubly compounded with narrow separate leaflets two to three inches in length. The flowers grow in clusters at the ends of the stem and are of a dull greenish white color. The flowers have an umbrella-like appearance similar in shape to the umbrella tree of the Southwest. The stems are hollow and whistles made from them have poisoned children.

The plant grows along the banks of streams and ponds and in wet vegas and marshes. It is found all over the West and is injurious to all stock and also to man. It is deadly in its action, and the operation of the poison 
is so rapid that full-grown cattle have been known to die from its effects within half an hour after eating it. The plant is easily recognized. It is not so common but that it can be eliminated from a range by a little systematic work in cutting or grubbing up the roots with a hoe or other suitable tool.

Aconite (Aconitum columbianum).-Known locally as monks hood or wolfbane, this pretty flowering plant is found all over the western stock ranges, and has been held responsible for many deaths among stock. It is believed, however, that these losses were due to larkspur, which is a near relative of aconite. It has the same blue flower of the larkspur and the same poisonous qualities, but as it grows in rough inaccessible places, and is not largely distributed, the losses from it are doubtless small.

Scrub Oak (Quercus gambelii Q. undulata).-Known also as "shin oak." This is the scrub oak of the western ranges, especially in the Southwest, where it forms as on the Texas staked plains great areas called "shinneries." In the higher foothills it grows to a considerable height in dense thickets, there known as scrub oak. It is an important article of forage for all kinds of stock, especially cattle at certain times in the spring. When there is plenty of other feed and the buds and young leaves are eaten in connection with other feed, no injurious effects are observed, but when feed is scarce and cattle browse almost exclusively on the oak, serious losses ensue. In New Mexico, Colorado, and parts of Arizona the losses from oak-poisoning are heavy among cattle in cold backward springs, when other feed is scarce.

The symptoms of oak poisoning are high fever; the lips and noses of the animals become scabby and sore; the flesh cracks; the eyes are deep-set; the hair all turns 


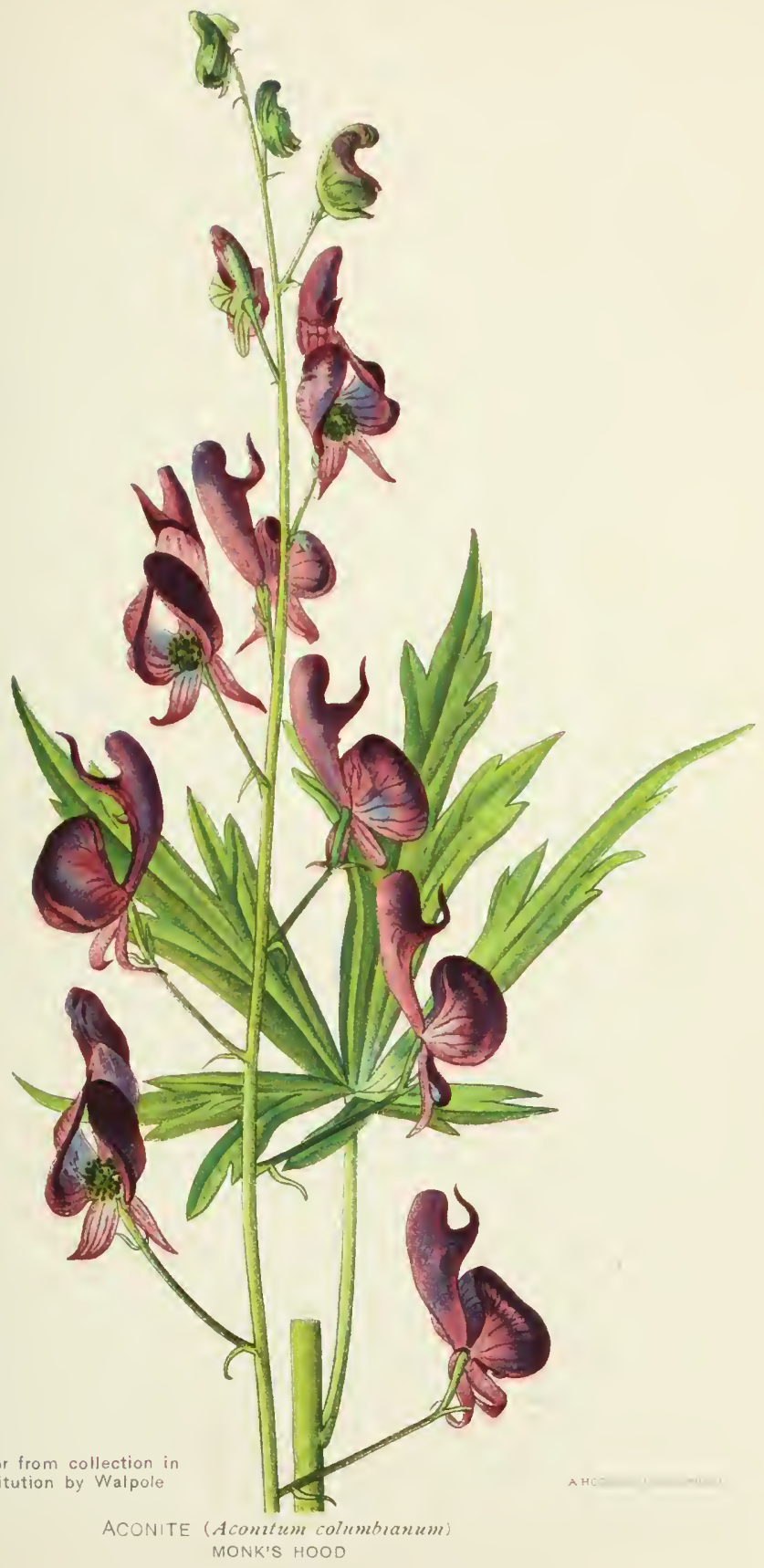



the wrong way. The breath comes with difficulty and in many respects the appearance is similar to loco poisoning. l'ost mortems show the stomachs to be very badly compacted, the contents appearing dry and burned.

The only known remedy is liberal doses of linseed oil given as a drench and injected. One quart for a drench if given early enough will bring good results, but if the case is not taken in hand promptly, nothing seems to do any good. It is possible that the use of a permanganate of potash drench in such cases would give excellent results, although it has never been tried to my knowledge. When cattle begin to die of this trouble the best remedy is immediately to remove then to some range where the oak is not found.

Pingue or Rubber Weed (Hymenoxys floribunda).In northern New Mexico and southern Colorado in the upper Rio Grande region there has been for several years past more or less loss from some disease known locally among the sheepmen as "pingue," from the Spanish name of the plant which is presumed to be responsible for the trouble. The rubber weed is a small plant, bearing a bright yellow flower about three-fourths of an inch in diameter, growing in the semi-desert ranges. Under commercial treatment it produces small quantities of a rather low grade of crude rubber. The story goes that the way the rubber in the plant was first discovered was due to the death of a ram whose stomach was opened in an effort to discover the cause of death. In the animal's stomach was found a mass that the investigators reported to be almost pure rubber. The sheep had been eating the bush or shrub, and the deductions were that the rubber came from the shrub and the animal died from the effects of the mass of rubber in its stomach. 
The matter is now undergoing a careful investigation at the hands of competent men, with a view to determining just what causes the trouble known as pingue, and whether or not it is due to the supposed presence of rubber. There is great doubt as to the entire question apart from the fact that many sheep die of the disease known as pingue. But that it is due to the rubber in the plant is believed at present to be very doubtful.

The pingue plant may be easily recognized in the spring by its black stems with small white seed heads at the ends. The green leaves show close down to the ground at the roots of the tufts and the whole area covered by the plants resembles a burned-over spot on the range.

For symptoms and remedies for pingue see page 280 .

Ergot (Claviceps purpurea).-This is a parasitic fungus which is found principally upon the heads of wild rye (Elymus condensatus) and bluestem grass (Agropyron Smithii). These two plants are found practically all over the western range country. The fungus which does the injury to animals is a small black spur-like growth between a quarter and a half inch in length which is attached to the seed heads of these grasses. The fungus growth contains the ergot and is eaten with the grass. Many stockmen believe the fungus to be part of the seed head of the plants. The loss of stock from eating the growing plants appears to be slight, the injurious effects being mostly confined to hay-feeding. when it is eaten with the seed heads and not noticed by the animals.

The losses are mainly confined to horses, although cases of death in both cattle and sheep have been known. Ergot-poisoning is deadly in its effects, acts quickly and 
owing to the paralysis of the muscles of the throat, making swallowing extremely hard, it is generally difficult to administer remedies.

\section{Sneeze Weed (Helenium montanum H. autumnale).}

-A smooth branching perennial, growing from eight inches to three feet high, sneeze weed has long lanceshaped leaves, with yellow flowers, and is generally classed by stockman as a species of sunflower. It is only dangerous where other feed is not available, hence is seldom eaten by animals unless they are extremely hungry. So far as is known, no domestic animals excepting sheep have ever been seriously affected by sneeze weed. The plant is found all over the West, mainly in the higher mountain regions. Old abandoned fields and pastures heavily overgrazed are generally full of it-in some places to the complete exclusion of all other kinds of plants.

The water contained in stock-tanks and reservoirs which have large amounts of sneeze weed in their vicinity has been known to poison sheep, and in two instances a number of men camped on small tanks or ponds of rain water otherwise pure but covered by the pollen from this plant were all made dangerously sick from using the water.

Choke Cherry (Prunus demissa).-This is the ordinary choke cherry of the West. It is not a dangerous plant, excepting when animals like sheep are driven for long distances over a range with little forage on it, and then reach thickets of the cherry. The hungry animals eagerly browse on the leaves and twigs which, taken into the empty stomach, develop prussic acid in sufficient amounts to kill them.

Heavy losses of sheep have occurred in Utah and 
other western states in which post mortems proved beyond all reasonable doubt that the deaths were caused by eating the leaves of the choke cherry bushes through which the trail-hungry sheep were driven. Sheep in this condition should never be driven through such thickets, if it is possible to avoid it.

Sleepy Grass (Stipa vaseyi).-This is a plant peculiar to the high mountains of Arizona and New Mexico. In appearance it is not unlike wild rye, growing to a height of from three to four feet. Local stock will not touch it, except when but a few inches high, and the only animals affected are those driven through the ranges and unfamiliar to the country. There are no records of cattle or sheep being affected by it, horses being the only stock on which any observations have been made.

I once saw a six-horse team belonging to a party traveling through the country turned out to graze near a large patch of this grass. The horses were very hungry, and the grass looked good to them. When the teamster tried to hitch up his animals some of them began to fall asleep as they stood in the harness. Their heads would drop lower and lower and sometimes the animals would sink to the ground, there to sleep soundly. If touched sharply they would jump all over, as if awakened from a dream, but drop off to sleep again at once, if left alone. This sleepiness disappears in a few hours, and to all ontward appearances the animals are none the worse for the experience.

Foxtail (Hordeum) and Squirrel Tail Grass.-The injurious effects of these grasses are entirely mechanical in their nature. The sharp awns or spikes of the plants work their way into the inner lining of the animal's lips and mouth, also affecting the tongue. They 
frequently work into the eyes and nostrils, forming festering spots wherever they enter. Death often ensues, owing to the injury to the tongue and mouth, preventing the animals from eating. In sheep the sharp awns also work into the wool and often into the hides, sometimes even causing death. 


\section{CHAPTER XIV.}

\section{SYMPTOMS AND REMEDIES.}

In order to make definite comparisons between the symptoms of various plant poisonings it has been deemed best to locate them all in one place. In this way it is believed the particular case may be more readily discovered. A general discussion of the various remedies will be found at the beginning of this chapter, page 246.

Bloat.-General symptoms: huge swelling on the left side of the paunch below the hip bone; animal groans and grunts as if in pain; labored breathing; animal seeks place like an irrigating ditch where it can stand with forefeet up-hill, thus throwing the paunch back from the lungs and throat.

Remedies: In first stages large doses of common baking soda given as a drench may give relief. Shove a section of a garden hose down the throat; this allows more or less of the gas to escape. Tie a short piece of hoe or pitchfork handle in the mouth like a bit; this keeps the mouth wide open and allows gas to escape. Run the animal around a field for twenty minutes at good speed; this works the gas off the stomach. Perform the operation known as "paunching" or "rumenotomy." To do this stick a trocar or long knife blade into the stomach about five inches below the left hip bone and the same distance back from the last small 
rib. There is no danger at all in this operation and it should be done promptly on account of the rapid progress of trouble. Sometimes the hole may be opened to about four or five inches in length and a portion of the contents of the stomach pulled out by hand. This, however, is seldom necessary, as, the pressure of the gas being removed, the ordinary operation of the stomach will soon clear out the mass of green feed to which the trouble is due.

Loco.-The following summary of the remedies covers the entire question of remedies. It is taken from Bulletin No. 112 of the Bureau of Plant Industry- "Loco Weed of the Plains"-by Prof. C. D. Marsh:

1. Some locoed animals will recover if taken from the weed and fed well without any treatment.

2. Most locoed animals will recover if they are taken from loco, fed carefully and treated on the lines indicated by our experiments.

3. In all cases care should be taken to relieve constipation, either through the character of the food or by use of magnesium sulphate.

4. Horses are best treated with Fowler's solution in daily doses of 15 cubic centimeters continued for at least a month.

5. Cattle are best treated with daily doses of strychnine, not exceeding three-twentieths of a grain, given hypodermically and continued for one or two months. It is especially important that the dose should be small, as locoed animals are very susceptible to the bat effects of over-dosing.

This then should be borne in mind: Use Fowler's solution of arsenic for horses, and strychnine for cattle.

To those who desire to study the matter more care- 
fully the bulletin mentioned would be extremely interesting as giving the experience of practical experts in handling this trouble.

Of course to the open-range stockman, apart from saving his saddle horses, it looks as if there was at present no help for him. To gather and dose large numbers of locoed range stock for two or three months would be too expensive and in most cases, owing to the nature of the animals, wholly out of the question. The only solution of their troubles is some sort of Government control whereby they may be guaranteed a certain range, exclusively, for a period of years. When this is done each man can easily afford to undertake to clean out the loco from his own range and thus be freed from the losses caused by the plant.

Larkspurs.--Symptoms: Similar to aconite poisoning. The animal walks with a stiff, awkward, straddling gait, often walking backward, and falling down repeatedly; is very stiff and clumsy and finally, in the extreme stages, falls to the ground in violent spasms, with convulsive kicking.

Remedies: Hurrying or moving the animals increases the effect of the poison, and they should not be disturbed, except that the head may be placed higher than the body, which prevents choking.

A strong drench to move the bowels will often save an animal. Frequently bloating accompanies the trouble, which is relieved by paunching (page 254), in fact the writer believes bloat causes death in this trouble as often as the poison itself.

Dr. Marsh* who has studied this plant carefully, rec-

*Farmers' bulletín No. 531 Dept. Agriculture. 
ommends this remedy for animals up to 600 pounds weight; over that, double the dose:

$$
\begin{aligned}
& \text { Physostigmin salicylate } \ldots \ldots \ldots \ldots 1 \text { grain } \\
& \text { Pilocarpin hydroclorid } \ldots \ldots \ldots \ldots 2 \text { grains } \\
& \text { Strychnin sulphate } \ldots \ldots \ldots \ldots \ldots 1 / 2 \text { grain }
\end{aligned}
$$

These can be found in any drug store. For either dose mix with 8 ounces water. Use the ordinary metal hypodermic syringe.

Lupines.-Symptoms: Great frenzy and mental excitement. Animals, especially sheep, will run about butting into anything they touch, as well as one another. This is followed by spasms and falling-fits, similar to those seen in strychnine poisoning. Death comes very soon-often within an hour. One of the principal symptoms is the increased amount and bloody appearance of the discharge from the kidneys.

The only known remedy that can be called at all useful is the permanganate of potash drench.

Camas.-The symptoms of camas-poisoning are similar to those noticed in cases of strychnine-poisoning. There is no wild frenzy of the afflicted animals but they are very restless and uneasy, with rapid breathing, slobbering and frothing with greatly increased amounts of saliva in their mouths. Regurgitation is frequent through the mouth and nostrils.

In the majority of cases death follows very quickly, and remedial measures must be taken as soon as the symptoms appear, if the animals are to be saved. So far as is known the only remedy is in the use of the permanganate of potash drench.

Water Hemlock.-Animals poisoned by this plant are subject to most severe pain. There is great cerebral frenzy with hard, irregular breathing, and violent mus- 
cular spasms. The animal will run wildly in any direction in which it gets started, never going far, owing probably to the severity of the pains. Death comes quickly, sometimes in fifteen minutes after eating the plant. Any efforts toward saving the animal must therefore be immediate.

If available give hypodermic injections of morphine in one-fourth grain doses, or one-half ounce chloral hydrate divided into three fifteen-minute doses. Also give the permanganate of potash drench. Where medicines are not available, and this is usually the case in this trouble, open the stomach of cattle as for bloat, and with the hands pull out the contents. This simply removes the poisonous matter from the stomach and if done soon enough may save the animal. After this has been done, give injections of melted lard, oil or even warm water, to move the bowels and carry off any remaining poisonous material.

Opening the stomach is not a serious matter, and this rough and ready surgery may save some valuable milk cow which would otherwise be lost. A few stitches in the cut to draw the sides together and a little tar or grease on the wound to keep flies away are all that need be done. It is remarkable how quickly an animal thus treated will recover and go to grazing again as if nothing unusual had happened.

Oaks.-Symptoms: The animals are weak and stand in one spot for hours, unless forced to move. In appearance they resemble locoed animals; the sunken eyes, grinding teeth and hair all set the wrong way being very like the conditions in loco. There is high fever with hard, labored breathing. The skin on the lips and nose is cracked and blistered from the fever. 
Post mortems show the contents of the stomach to be very dark, dry and impacted, due to the tannin in the oak. The gall sack is greatly distended with a clear syrupy liquor and the urine is generally quite bloody.

Remedies: The only remedy I have seen tried is the use of large drenches and injections of oil, linseed being usually the most available. Melted lard will probably bring equally good results. If available the drench of permanganate of potash might be used to advantage, although the progress of this disease is so slow that in all probability the poisonous matter is too thoroughly incorporated into the system to make its use effective.

The trouble does not begin to slow itself until the animals have eaten a large amount of the oak leaves, and they generally linger in their misery for ten days before dying.

Ergot.-Symptoms: Paralysis beginning at the throat and mouth; the action of the animal is similar to cases of strychnine-poisoning. The victim is unable to use its limbs, staggers and falls about; appears very tired and disinclined to work. Horses sweat profusely about the neck and head. The paralysis, which starts with the mouth and tongue, gradually extends to the entire body. Owing to this paralysis the animal is unable to swallow, hence remedies are very hard to give, excepting as injections. There is no excitement or hard breathing, the respiration being slow and deep, as if in a stupor.

Remedies: Any stimulant, such as alcohol, ammonia or strychnine, may be used. The action of this poison is rapid and deadly, and any efforts to save the victim must be prompt. Permanganate of potash should be 
tried, although no cases are known to the writer where it has been used.

Sneeze Weed.-Symptoms: Continual sneezing and coughing. This appears to bring about vomiting, which becomes serious, frequently ending in death. No remedies are known. A drench of a quart of melted lard or any oil may be useful. The most important thing is immediately to remove the animals from the range where the sneeze weed is found.

Choke Cherries.-Symptoms: Severe pains with acute frenzy and early death. The sickness is due to prussic acid contained in the leaves; the action is rapid and there is little time in which to administer remedies. A permanganate of potash drench should be used, together with an injection or drench of oils to assist in carrying off the matter from the stomach.

Pingue.-The symptoms of this poison are not very well known at present. The disease is confined entirely to sheep. The animals appear drowsy and with no desire to eat. They finally lie down and unless forced to rise will seldom get up again. The progress of the disease is rapid, and losses are heavy. The only remedy known at present is the use of a drench of hot strong brine, given every hour until the animals recover.

Kafir Corn and Sorghum.-Cattle and sheep turned into fields of Kafir or sorghum often die very suddenly. This is due to the presence of prussic acid, which appears to develop in these plants whenever their growth is checked in its early stages by either frost or unusual drouth conditions. Thus the young growth of both of these plants is a very dangerous feed; and stock 
should never be turned upon it when it has been frosted or its growth checked by dry weather.

The greatest losses usually follow the turning of stock into ficlds in the fall, from which the crop has been harvested. The young growth that always springs up from the stubble is exceedingly dangerous at such a time, and what feed there is in the field may better be wasted than to risk the losses that are sure to follow. Hogs, however, seem to be perfectly immune to this poison and may use such feed without danger.

There is no known absolute remedy for prussic acid poisoning, unless it be the permanganate of potash drench, and generally the animals are dead before anything could be done, as it is one of the most deadly and active poisons known. 


\section{DISEASES OF LIVE STOCK.}

While it is impossible within the limits of a short article to cover all the diseases to which livestock is heir, there are several which affect domestic animals throughout the WVest. These might be called "standard diseases" because of their general prevalence. Some of the diseases from which stock suffer are caused by eating poisonous plants, and have been considered elsewhere in this work. Not only should the Western man be able to recognize the common diseases that affect his stock, but he should also be able to administer or suggest the necessary simple remedy.

Where a veterinary surgeon is available, he should be called. There was a day when the village "horse doctor" generally was a "quack," with little or no scientific or professional knowledge of the work which he undertook to do; but the veterinarian of today is as much a professional man in every sense of the word as is any doctor of medicine. A graduate from any of the well-known veterinary colleges-is fully as competent to take care of the health of dumb animals as the doctor is to care for a family.

Many a valuable horse or cow has been lost by its owner following the advice of every one who came along, thus burdening the poor animal's stomach with a variety of remedies, all more or less antagonistic to 
one another. Who has not seen a cow dosed with soda by the advice of one man, and ten minutes later. on the advice of some one else, given a quart or two of vinegar-one an alkali and the other an acid? Better by far no medicines at all, excepting salts or oil to move the bowels-an excellent measure in all cases of sickness.

Do not be coaxed by the village sage into having the "eye" or "blind" teeth of a young horse knocked out on the theory that they cause sore eyes and blindness. No graduate veterinarian will recommend such procedures or admit that they have the least connection with the eye trouble. Do not let the same wise man talk you into taking a red-hot iron and burning out a horse's upper gums in the belief that he has "lampers" and that it is going to cure it, for it will not. Do not decide that your horse is suffering from "bots," because there is really no such disease. In almost every healthy horse the larvae of the bot fly (Gastrophilus equii) will be found in the intestines where, excepting in extreme cases, they apparently do no great injury.

Because a cow will not eat, fails to chew the cud (ruminate) and seems sick, do not let the village "knowit-all" make you believe she has "lost her cud." Do not shove down her throat with a pitchfork handle a wad composed of a slice of salt pork as large as your hand with some pieces of laundry soap wrapped inside it, in the fond hope that it will cure her by replacing the cnd which the aforesaid "know-it-all" assures you she has lost. The cow is a ruminant, that is, she eats a lot of feed, stores it up in her first stomach temporarily, then goes off to a comfortable spot, regurgitates (literally vomits) it back into her mouth and proceeds 
to chew it into shape to be digested. When she has fully masticated one lot it is swallowed and goes into the second stomach while, if she is undisturbed, she raises another cud and repeats the process. This is chewing her cud. If a cow fails to chew her cud she is simply out of sorts, her digestive apparatus is wrong somewhere, and the only remedy is something that will cure the indigestion.

As in the human, loosen up the bowels with a dose of salts or oil, give her an injection of warm, soapy water, change her feed, give nature a chance to effect a cure and let her alone as much as possible. Bots, blind teeth, burning for lampas, hollow horn, wolf tail and several other old-fashioned stock diseases have given way before modern scientific investigations and are not now part and parcel of the veterinarian's diseases.

There are two books published by the United States Department of Agriculture, "The Diseases of Cattle" and "The Diseases of Horses," which should be in the hands of every stockman. They may be secured through Congressmen. In these two volumes the various diseases from which horses and cattle suffer are most admirably treated and the remedies are those which every stockowner should have on hand, ready for emergencies. The easiest manner of administering medicines to animals is of course through the medium of feed.

Bran, corn chop, or other soft feeds may be used if the medicines are not injurious to the linings of the throat or mouth and have no disagreeable taste. This is the most satisfactory method. Generally, however, a sick animal is one that is not eating, hence the commonest method is by means of drenches through the mouth or injections through the rectum. A beer bottle 
is the most available vehicle for the purpose, and care must be used not to allow the neck of the bottle to get between the grinding teeth of the animal, lest the bottle be broken and the animal injured by glass.

If a cow which is being treated coughs, the head must be lowered at once, lest the animal choke or some of the liquor be forced down the windpipe into the lungs, causing serious injury and possibly pneumonia. Raise the animal's head gently to an angle of about 45 degrees, push the bottle neck into the right side of the mouth so that it rests on the middle of the tongue and allow the contents slowly to run out. Usually between a pint and a quart of fluid is all that is necessary to carry the medicines into the animal's stomach. In impaction of the stomach, however, the dose may be as much as a gallon or even more.

See that all crystals are completely dissolved in the liquor before giving it, so that they may be carried into the stomach and not be left in the mouth. If it is desirable to administer through the bowels it may be done with a syringe or by means of a picce of common rubber hose four or five feet long. Oil or soap the hose and push it carefully into the rectum, leaving a foot or eighteen inches outside. Elevate this and use a tin funnel through which the medicine may be poured and it will find its way by gravity into the bowels.

Do not give liquid medicines through the nostrils. Nany a valuable animal has been killed by this practice. 


\section{CHAPTER XVI.}

\section{THE DISEASES OF CATTLE.}

There are but three diseases among western range cattle which can be considered general: Big jaw (actinomycosis), bloating (tympanites) and black-leg. Bloating has been fully considered under the head of poisonous plants. Big jaw, also called lumpy jaw and wooden tongue, is an infectious disease found generally all over the West. It is a chronic disease and due to the formation and action of a fungus growth. It is not carried from one animal to another by mere contact but must be taken into the system through some abrasion of the skin in the lining of the mouth or decayed teeth. The fungus is found on grasses and the sharp awns of barley and other grains. These work into the membrane of the mouth, the tongue and gums of cattle.

In certain stages of the disease animals with huge, running sores on their jaws drink from troughs, pools and tanks into which the matter from the sores drops, and it is an easy matter for the fungus which carries the trouble to find its way into the system of a healthy animal. It is not very probable that the disease is often spread by this means. While the tumors may appear on various parts of the animal, it is generally on the lower jaw bones that they are found. The trouble begins with a small swelling which gradually grows until it assumes considerable size, finally breaking out with a running sore which spreads and grows until the 
entire jaw is frequently covered. It also works back into the inner part of the jaw, attacking the bone itself as well as the tongue, when it is called "wooden tongue."

An animal in an advanced stage of the disease will show a peculiar honeycombed appearance of the jaw bones when the flesh is opened to the bone. In a few cases animals affected with this disease recover without treatment and probably about 75 per cent of the afflicted can be cured if properly treated. The cause, progress and peculiarities of this disease are little known to veterinarians, and there is much ignorance as to the facts in regard to it.

The most common nethod of treating big jaw has been to cut away tumors where this is possible, even to scraping the diseased bones. This, however, is seldom a permanent cure and the disease soon reappears. Recently veterinarians have discovered that a treatment of iodide of potassium will in most cases effect a permanent cure. The iodide is given as a drench in doses of from $1 \frac{1}{2}$ to $2 \frac{1}{2}$ drams dissolved in water, once a day. The dose should vary with the size of the animal and the effect of the medicine. In the course of a week or ten days signs of iodism appears. The skin is scurfy, there is weeping from the eyes, catarrh of the nose and loss of appetite. When these symptoms appear the doses should be stopped for a few days, and then resumed. The remedy will generally effect a cure in four or five weeks. If it does not it is a sign that the particular animal is not subject to the influence of the drug and cannot be cured.

The disease is not considered injurious to the meat of the animal excepting in extreme cases and those of long standing. However, all cattle buyers look care- 
fully for animals with small swellings on the jaw or side of the face, and reject them on suspicion. At the market animals with the disease are thrown ont by the Jovernment inspectors and given a careful examination, with the result that a large number of them are allowed to go to slaughter as fit for human consumption.

Blackleg.-This is a discase of the blood. It is infectious but not contagious, and confined almost wholly to animals between the ages of eight months and two years. Probably 80 per cent of all the deaths from blackleg are confined to animals between ten and fourteen months old. Cases where cattle over two years old have died from it are extremely rare and the number dying under eight months is not large.

The disease has certain well-defined peculiarities. There are seldom any outbreaks of blackleg during a wet season, hence a certain area will be free from the trouble for several years. During a dry year when the dust about watering-places and salt-grounds is deep and blown about by the wind, stockmen prepare for a loss by blackleg. As a general thing, the fall is the favorite time for the appearance of blackleg, although a dry spring will develop it under certain conditions. These conditions depend upon the physical condition of the animals. As a rule, the disease attacks the flower of the herd. The fatter and better bred the animal, the more likely it is to have blackleg. Seldom does the disease attack a poor animal, and as most range cattle are far from fat in the spring, it doubtless is due to this fact that the losses are more common in the fall. After the summer season everything is fat and in excellent condition to contract the trouble.

Another thing that seems fairly well established 
through years of observation is that blackleg was seldom known in the early days of the range business when the herds were bred altogether from the old long-horned animals of the Southwest. It will hardly do to say absolutely that the scrub will not contract blackleg but it is very likely that if a careful watch were kept of the progress of the disease in a bunch of 100 pure-bred yearlings and 100 scrubs, all grazing on the same range, and under identical conditions, a large majority of the losses would be among the pure-breds.

Blackleg is not what the medical fraternity calls a sporadic discase. It cannot originate through certain physical conditions on a range where it was never before known. It must have been conveyed there through the death of some afflicted animal which, dying, carried into the ground the bacilli of the discase. Just how long the bacilli lie dormant in the ground is not known. I know of one case in Arizona where a yearling dying of blackleg was buried several feet deep on the banks of a creek near a watering-place. Six years later the caving of the bank along the creek uncovered the bones of the animal and not long after there was an outbreak of blackleg in the adjacent pasture. As there had never been but one known death from the disease before, and since the cattle were in the habit of lying along the creek in the shade of the high banks, there was little reason to doubt that the disease was taken into the animals' systems through small cuts on their bodies coming in contact with the ground, or perhaps licking themselves or one another, and thus carrying the deadly bacilli into their circulation through sore places or cuts upon the inner parts of the lips or tongue. That this is possible has been repeatedly proved by experi- 
ments made by several institutions, notably the Oklahoma Experiment Station.

Calves were kept under identical conditions. Earth taken from the spot where an animal had died from the disease was placed in their feed in such a way that they must swallow it. Those with mouths free from all cuts or injuries whereby the bacilli could enter the system suffered no harm, while those having such cuts or injuries died. Again, two animals were taken and one given several gashes in its hide, deep enough to go through to the flesh. Soil from the same place was rubbed all over each calf, working it down into the hair close to the hide. The animal with the cuts in its side died of blackleg, while the other showed no signs of the trouble.

Every stockman knows that there are certain places upon the western ranges where the disease is apt to occur, while just over a mountain range or across a river it never has been known. Again, in fenced areas like northern New Mexico pastures and in the Texas Panhandle fifty animals will die of it in a week, while in the next pasture, only separated by a wire fence, stock will graze in perfect health. The simple explanation is that the second pasture has never been inoculated by having an animal with the disease die inside of it.

If every animal that died of blackleg could be burned or buried in quick lime it is probable that the disease could be stamped out in time, but the trouble on open ranges is that they die in the canyons and other unnoticed spots where the escaping juices from the decaving body run out over the ground, scattering the seeds of the disease. Years after a calf lies on the spot and through some cut or open sore the dust from the 
earth gains entrance into the circulation and the animai lias blackleg.

The disease is also scattered by buzzards, ravens and other carnivorous birds that feast upon the dead bodics, carrying pieces to distant places and thus infecting other spots. The disease does not affect the meat, at least not to the extent of conveying the discase, for in New Mexico the natives, both Mexican and Indian, eagerly seize upon the body of an animal dead from blackleg and eat it with no resultant injuries.

The symptoms of blackleg are a slight lameness growing rapidly worse; disinclination to travel and death without any particular struggle or suffering.

The disease incubates rapidly and the time between the first visible signs and death is short, gencrally not more than twelve hours and sometimes not more than five or six.

There can be no mistaking an animal that has died of this discase. An hour after death the body is swollen to the uttermost stretch of the hide. The legs are distended at full length, standing out from the body like sticks; the mouth is wide open; the eyes bulge out; and the openings of the body forced far out. On pressing the hand upon the body it feels like a drum and if the finger be pushed into the fleshy part of the shoulder or leg a dry crackling sound will be heard, caused by the gas formed between the skin and flesh. Drive the blade of a knife into the flesh and a frothy pale liquid will ooze out, but the blood does not flow as in ordinary cases of death.

It is not known whether the disease can be transmitted to man, but I know of one case where a cowboy had skinned several calves dead from blackleg. He used 
his pocket knife for the work, placing it when done, wet with blood, in his pocket. The following day in a fight he was shot through the leg and the bullet struck the knife, burying it deep in the flesh. The leg was amputated soon after but in spite of all that could be done the man died in a few days of blood poisoning which many afterward thought to be blackleg. Unfortunately no one thought at the time to watch the symptoms carefully nor were any tests made of his blood to ascertain whether or not the bacilli of blackleg were present. That this man died of blackleg was and still is the conviction of nearly every one in that region acquainted with the facts.

Remedial Measures.-When there is an outbreak of blackleg it is too late to save stock already affected. Veterinary science can protect the well but cannot save the sick. The immediate removal of the stock from the infected pasture or vicinity is the first thing to be done. A common method of fighting it is for the men to mount their horses and run the whole herd around the pasture or range for some time. In this case the theory is that it starts the blood to circulating and stops the coagulating process which is the effect of the disease.

I have known men to spend a whole day driving a herd of cattle about on the range and not lose one from blackleg. Of course there is nothing settled by this statement, because it is impossible definitely to state that any of the animals so handled were suffering from the disease when the chasing process began. In addition to this setons formed of strips of cotton cloth soaked in assafoetida, turpentine and the like are placed in the skins of the suspected animals. Some men run them through the dew-lap and others through the tail. 
close against the body; and still others, through the shoulder where one places a seton in a sweenied horse. That these remedies do any good is doubtful. No trials have ever been made with animals positively known to be affected with the diseasc, so that it can neither be denied nor affirmed.

The only known remedy or rather preventive that has been tested and approved by careful experiments both in the United States and Europe is inoculation. This is done by various means. The most successful is the method employed by the Government which is by means of hypodermic injections of a solution prepared by mixing a certain quantity of the finely pulverized dried muscle of an animal that has died of blackleg with distilled water. This is forced by the syringe into the cavity between the outer skin and the flesh, preferably on the shoulder. Animals thus treated are immune from attacks of blackleg if it is done after the calf is eight months of age. If clone earlier the animal seems to outgrow the immunity and if exposed will contract the disease.

Animals so treated seldom die of the disease, the percentage being extremely small, and then it is not always certain that vaccination was properly performed. It is estimated that on many western ranges on an average fully 10 per cent of all the calves die of blackleg. I have known forty calves out of sixty to die in ten days in one pasture in spite of all the remedies used. On the other hand where vaccination is regularly followed the loss is almost wholly wiped out. the few that die probably being cases where the dose was wasted through carelessness on the part of the operator in not getting the needle in the right place. In 
the rush of doing the work the needle can very readily be stuck through a fold of the hide in such a manner that it will come out on the other side of the fold unnoticed in the hair, and the dose never enter the animal's body at all.

I have vaccinated my thumb at least twice, and jabbed a dose into one man's leg through accident, with no harm, except a close call for a good drubbing at the hands of the enraged cowboy. There are several patent remedies on the market for blackleg, the most of them being some form of administering the powdered muscle without going to the trouble of mixing up a liquid and injecting it through a hypodermic syringe. I'dubtless those manufactured by responsible firms are as efficacious as the powders furnished free by the Government. The main thing to be looked after in them all is that they are fresh. Most of them are dated, showing the day they were made and the extreme length of time which they may be kept and still be effective.

Texas Fever.-While this disease is not general over the West, it is well that the grazier should know something about it. Broadly speaking, it is confined to all the coast country of the United States which lies below the 1,500-foot level, south of Cape Hatteras and clear around to the Gulf Coast. This level is not an exact line but the ticks do not survive very cold weather, and above the 1,500 -foot line the winters generally kill them. Texas fever is found in nearly all of the southern states and along the coast counties of southern California.

Nany years ago when the Texas trail was in full swing the cattle grazing along the trails followed by the Texas herds died of some mysterious disease. The outbreaks seemed unaccountable. The disease did not 


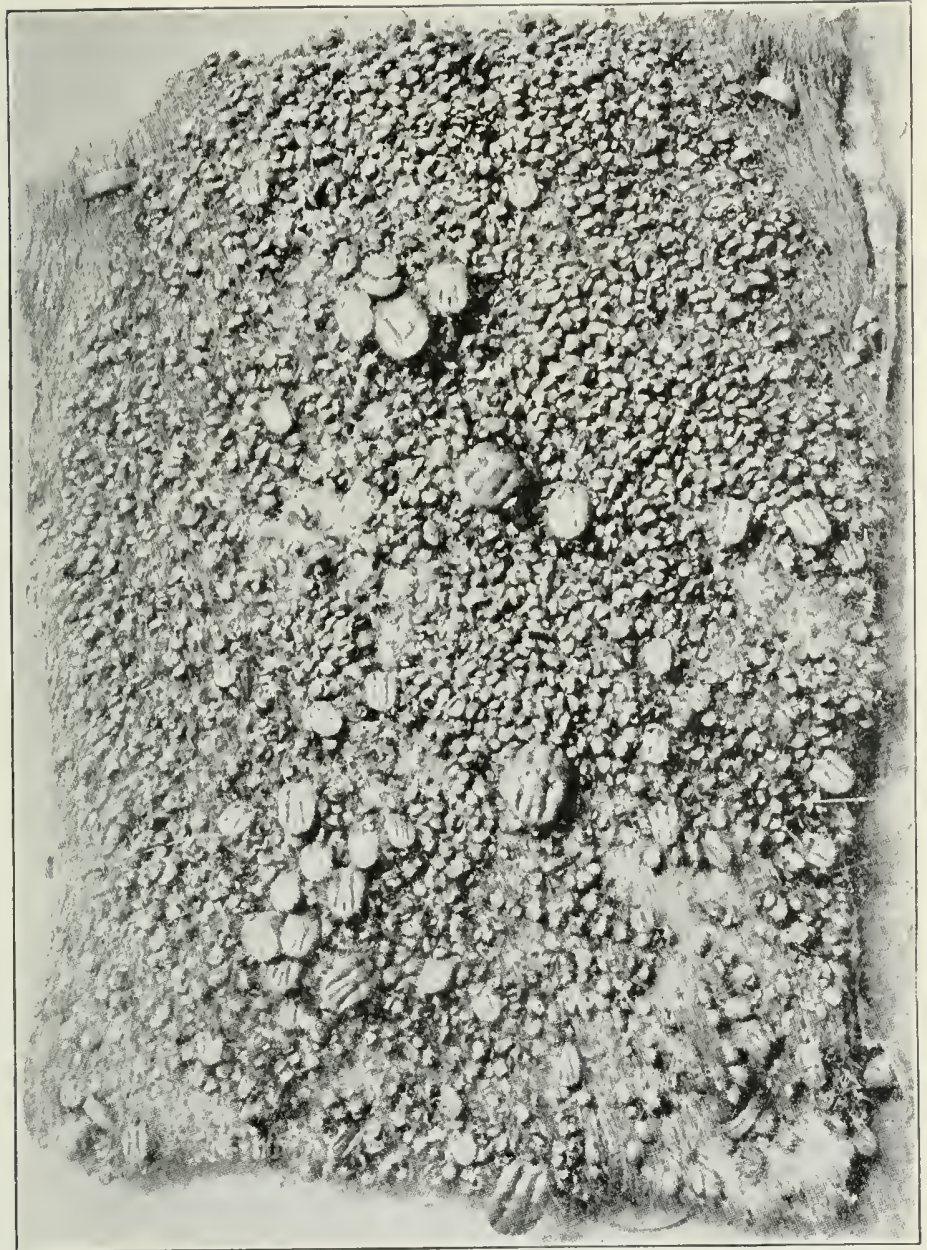

Portion of a Steer's Hide, Showing the Texas-fever Tick. 
last long and did not seem to spread beyond the animals first attacked. The settlers soon discovered that the victims were all northern stock and that none of the Texas animals died. They also realized that the losses were confined to the cattle which grazed about the old bed-grounds where the trail herds had been bedded down for the night. The disease was attributed to many causes. The droppings of the trail animals were supposed to convey it in some manner. Again it was the slobber of the animals grazing on the grasses by means of which the trouble was caused. In fact, dozens of theories were adranced for the cause of the deaths.

The settlers arose in their wrath and met the trail herds with their rifles and in some sections strict guard was kept that no trail herds entered certain districts. For years no amount of investigation seemed to solve the problem until a veterinarian took up the question of the ticks which were carried upon the bodies of all Texas cattle. At first his theories were ridiculed. "All cattle had ticks." "The buffalo had them; all the northern cattle had them in their ears; deer had them; horses sometimes had them." But the veterinarian persisted in his studies of the matter and eventually proved that the ticks which infested the Texas cattle were different from the common ear tick and that their bodies filled with blood drawn from the Texas cattle conveyed the disease to healthy cattle.

Still the Texans doubted. "Their cattle were the healthiest in the world." "If the ticks were so deadly why didn't their cattle die?" This side of the question was one which took nany years of painstaking investigation thoroughly to clear up, but it was finally 
done to the satisation of even the Texans. For several years the "bull tick" theory was the basis for many a shot at investigating reterinarians. The gist of the matter was that lexas cattle through long years of infection had become immune to the disease, and while still carrying in their blood the deadly bacilli of the disease did not themselves succumb to it.

The Federal Government in order to prevent the spread of the disease has drawn a line called a quarantine line which extends from the Atlantic Coast clear across the South and southwest, running as far north as the northern line of Oklahoma and southwest across the northwest portion of 'Texas to the Mexican line. From below this line 110 cattle may be removed excepting for immediate slaughter. At the present time the Government is experimenting in the dipping of tick-infested animals with excellent results. A campaign is also being carried on looking to the complete eradication of ticks from the lands. This process is a long one and to be successful must have the hearty co-operation of interested parties.

By means of changing pastures, moving the cattle back and forth and keeping all stock off certain areas for definite periods, the ticks may be starved out and the land freed from their presence. Twenty years ago all of California south of San Francisco was infested with ticks and under quarantine. Today by these methods the state is free from ticks.

The life-history of the tick furnished the means of its extinction. It was found that the tick lived on an animal for a certain time, then dropped off, laid its eggs and died. The eggs so planted developed, according to the weather, in the course of thirty to sixty days. The young 
seed ticks then began crawling about looking for some animal to which to attach themselves. At the first opportunity this was done, and they crawled upon the unsuspecting beast and began to derelop immediately into good-sized ticks. In from fifteen to twenty days, if the animal is not immune, the disease breaks out. In three weeks the insect grows to adult age, drops off and begins to lay its eggs under some convenient chip or piece of dung, and so the process is repeated indefinitely.

The ticks may generally be discovered inside the thighs and on the escutcheon and belly where the hide is tender and the hair is short. While most all cattle have ear ticks, and some body ticks, it is not difficult to recognize the true fever tick.

Place a fever tick upon the hand and if it is fullgrown it will be all day crawling across it. An ear tick of the same size will do it in a few minutes. The full-grown female tick is of a slaty blue color, about as large and much the shape of a grain of corn, and with eight legs. The male is smaller, rather triangular in shape and in color a brick-red. The male's legs are much longer than those of the fumale. The seventeenth anumal report of the Bureau of Animal Industry contains a full and finely illustrated story of the Texas ferer tick which should be read by every one interested in the subject.

Scabies or Mange.-This is a cattle disease similar to scab in sheep. The mites, however, are a different rariety of the same species, and the sheep mites will not attack cattle nor will cattle mites make a host of sheep. The symptoms are the same in each case. The constant desire to scratch, raw bleeding necks and shoul- 


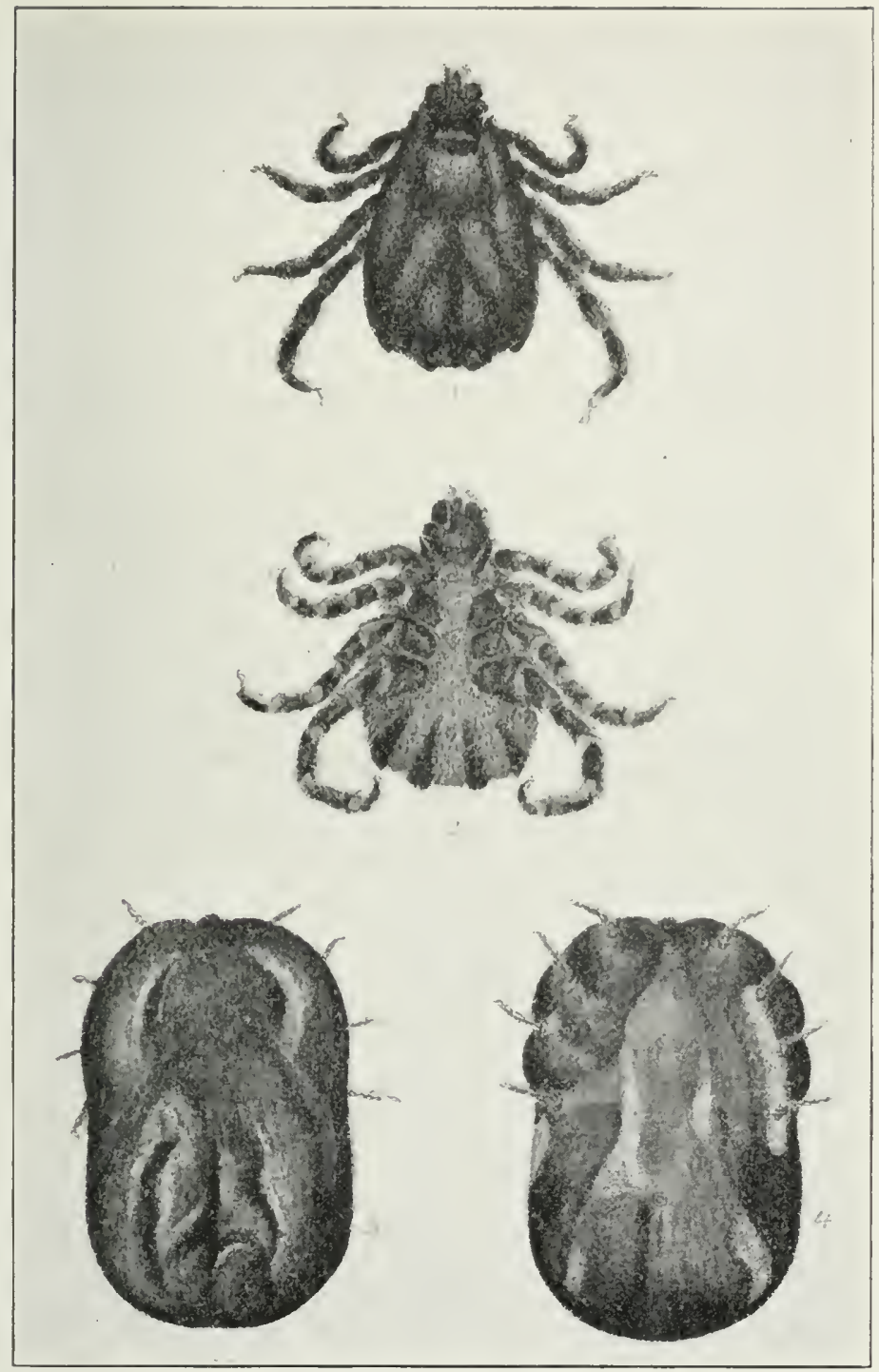

1 and 2, Male. 3 and 4, Female.

Dorsal and Ventral Views of the Texas.Fever Tick. 
ders where the animals have scratched till the flesh is torn and a falling off of the hair until in extreme cases the victims are almost bare-all these conditions point to the trouble.

The disease, which has existed in the western ranges for many years, did not reach any serious stages until about ten years ago, being contagious but very slow in spreading. Mange does not primarily cause the death of cattle but simply cuts their vitality down and saps their strength till they fall easy victims to bog holes or hard winters. So long as the animals are in good Hesh they seem able to withstand the attacks of the mites and the disease makes but little if any headway. With the coming of a hard winter, short feed and long storms, animals rapidly lose flesh, and then the mange mites begin to thrive.

Some veterinarians think that the mites are repulsed by the excess of fat in the animals' skins and lie dormant until this excess is lost, when they emerge from their hiding places to feast on an already suffering and debilitated animal. Thus it is that the disease may exist in a herd for a long time and then during some hard winter when the cattle lose flesh the mange makes its appearance and the owner wonders where they "caught" it. Western stockmen made no serious fight against the mange until through shipping it had spread all over the country west of the Mississippi River, especially on the eastern slope of the Rockies and out into the great plains country to the east. Then the United States Department of Agriculture took hold of it, and in six years has been able greatly to reduce the infected area and in some states has completely eradicated it. IJad the Government from the first secured 
the co-operation of the states and stocknen interested, as it should, the disease would not exist torlay anywhere in the Wrest, excepting in isolated cases.

The same methorls of fighting mange are used as with scabloy sheep and the losses from dipping are very light-no more than the losses in dipping sheep.

Dipping a herd of cattle is no light task, and the ontlay for a dipping plant is much greater than for sheep. However, the ridling of the cattle of lice, ticks and other parasites that worry them makes the operation one from which the stockman gets good returns, and many fond it a wise plan to (ip their herels at least once every two years for this purpose alone.

A successful spraying machine is now used with excellent results. The animals are driven through a long steel cylinder large enough to let them walk through readily. Inside this cylinder thousands of needle-like nozzles spray a hot liquid dip, the basis of which is Texas crude oil. This is forced out at tremendous pressure and the animal is thoroughly covered with the solution by the time it reaches the exit.

The cost of dipping cattle by any methorl is about 15 cents per head for each operation, but this may be reduced by luandling a large number of cattle at one plant. Is with sheep, where the animals are gentle and can be handled, they may be doctored for mange by swabbing them over with the solution, giving the rubbed and bare places a vigorous scrubbing with a stiff brush dipperl in the "medicine."

In the spring. when they are shedding: cattle are likely to look as if mangy, but they are simply losing their winter coats and rub to get rid of the hair. If one is fearful of the presence of mange mites, take hold of 


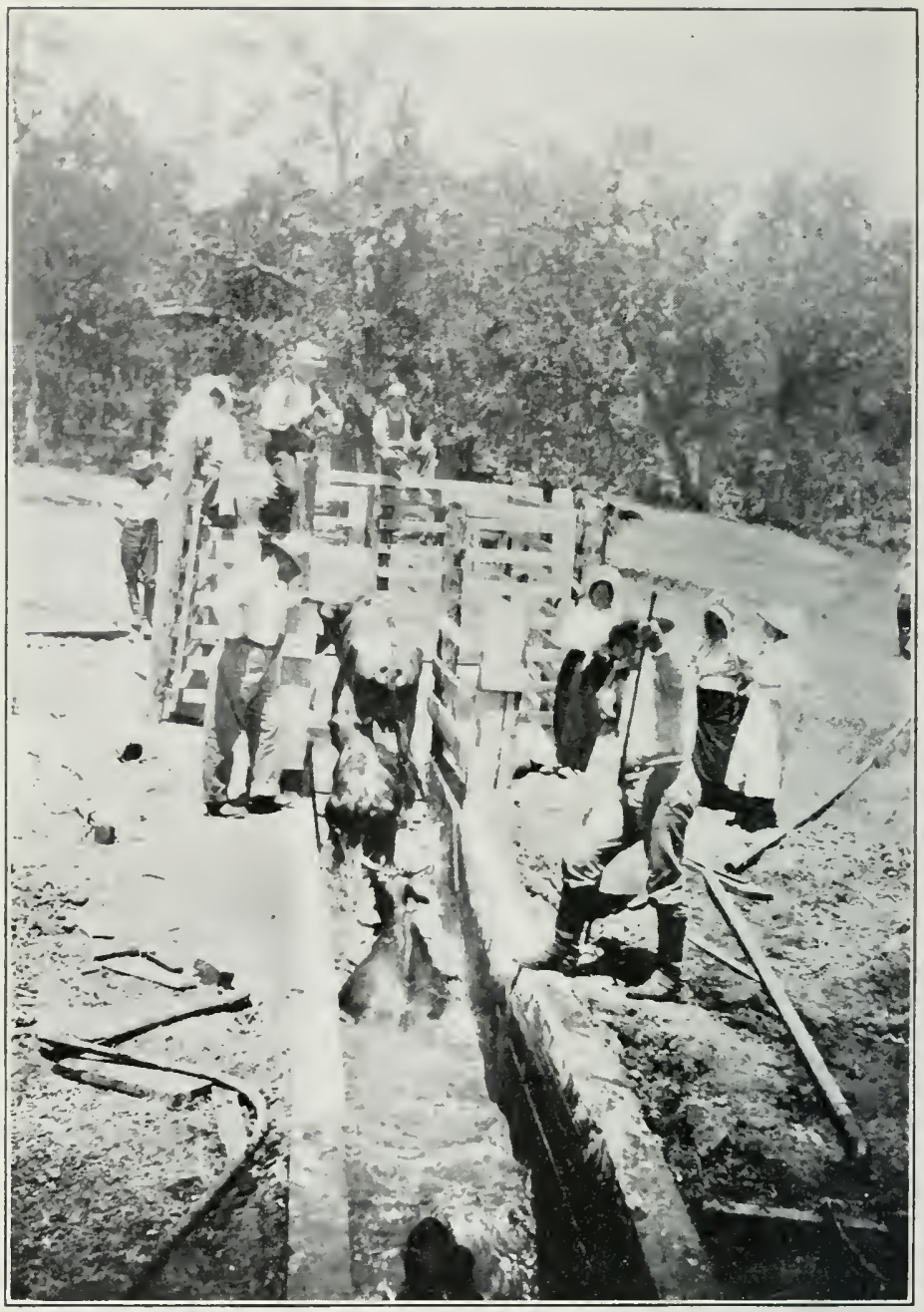

Dipping Cattle in Oklahoma for Texas-fever Ticks. 
the hair where they are seen to scratch and pull off a flake of it. Py placing the lock of hair nnder an ordinary glass, such as almost every Western man has handy, and examining it closely at the roots, the mites, if there are any, will readily be discovered, very much alive.

In mange scurfy scale-like stuff comes away with the hair, which is but the dead tissue where the mites have burrowed in the skin and the scab which forms sticks to the roots of the hair. The disease annong horses is much the same in all its symptoms and can be similarly handled.

A few years ago in northern New Mexico mange obtained a footing and spread among the range horses nuntil with a very hard winter thousands of horses died. Probably many of them would have died anyhow but any one seeing a bunch of the horses, some of them as bare of hair as a picked chicken, with great raw places on their necks and shoulders where they scratched on the rocks and trees, had little doubt that mange did much to hasten the coming of the end. A strenuons campaign of dipping the next season carried on by the territorial authorities stopped the spread of the disease and, so far as can be seen torlay, completely cradicated it. 


\section{CHAPTER XVII.}

\section{THE DISEASES OF SHEEP.}

Practically scab is the only disease which bothers the western sheepmen. Foot rot, intestinal worms and those diseases which are a blight on the sheep industry east of the Mississippi River are unknown in the regions west of it. This is due doubtless to the high dry atmosphere which offers no climatic conditions favorable to the progress or eren inception of these diseases.

Scabies.-Thanks to the tireless work done by the Bureau of Animal Industry, this trouble has been so successfully combatted that it is practically eliminated from many of the range states and is found in very isolated cases in the balance. This work was not done without considerable friction and criticism from the very men whom it was intended to help. Naturally the progressive go-ahead sheepmen eagerly welcomed the coming of the government men with their constant inspections and never-ceasing vigilance; but to many it seemed an unnecessary hardship: as well as an invasion of their individual liberties.

Some of the states had fought the scab through their local officials but no great headway was made until the Federal Government took a hand in it, and by virtue of its authority to supervise interstate shipments of stock compelled those who would not dip to protect themselves 
to do so to protect others. The Federal authorities could not go on the ranges and (fuarantine the sheep, but as soon as offered for interstate shipment it could quarantine and thus force the owner to take care of them.

The states were generally quick to co-operate with the Government in this matter, and in the most of them they worked hand in hand, with very satisfactory results. Naturally where a state has mee leen freed from this disease a molerate amount of supervision and watchfulness on the part of the local authorities will prevent any further spread of the trouble.

Scab is one of the oldest of animal diseases. Mloses in his voluminous instructions to his followers, speaking of sheep offered as sacrifices to the Lord. says in L,eviticus $22: 22$ :

"Blind or broken, or maimed, or having a wen, or scury or scabberl, ye shall not make an offering."

Scab exists almost everywhere where sheep are raised. In Europe. Asia and Africa it is common. Australia fought it with success and very little of it is to be found among the millions of sheep there. The cause is a species of mite known as Psoroptes communis. Psoroptes is a Greek word meaning "mites that hide under the skin." Horses and cattle also have scabies, but the mites are different, and the disease cannot be carried from a sheep to a cow. or vice versa. It can, however, be contracted by man. Sheep have been known to contract the disease after being bedded down on a bed-ground which sheep had not used for more than a vear. As the disease is carried entirely by the mites they must have lived in the ground for that long at least. 
These mites on obtaining a position on an animal begin at once to bore into the hide. This creates the intense itching. a crust or scab is formed, the mites move onto the adjoining healthy flesh and thus the disease spreads.

sheep afflicted with scabies are easily discovered in a flock. The animals are restless, scratch and rul, against posts and walls and bite the itching places until in severe cases their noses will be all bloody and the flesh torn and bleeding. It generally shows first about the neck and shoulders, because the suffering animal can more easily reach that part to scratch. The wool has a peculiar tagged or tufted condition and bare spots appear on the animal where it has fallen off, due to the work of the mites. After being driven or heated up, the animals are worse, as the increased heat of the body tends to aggravate the desire to scratch.

Remedies.-Fortunately scab is a disease that can be readily stamped out. In snall herds where the animals are under close control, by catching each animal and "doctoring" it with a commercial dip smeared on with a swab or rag soaked in the fluid, wherever there are signs of it, the trouble can be checked. In large herds. as on the western ranges, dipping plants are used. These plants are sometimes owned by the sheepmen, in some cases they are built and maintained as commercial enterprises, a small charge being made for their use. Under usual conditions a large number of sheep can be sent through a dip each day, and with a good crew there is little delay in the operation. The swim generally is so timed that each sheep is in about one minute. The men in charge see to it by means of forked sticks that each animal is "ducked" completely under at least once during the swim across. 
Dips in Use.-There are sereral different dips in use known from their ingredicnts, as creosote, tobacco with carbolic acid, lime and sulphur. The latter (lip) is generally used by Govermment officials. The majurity of these (lips must be used when heated to get the best effects, and in order that the disease may be absolutely cured

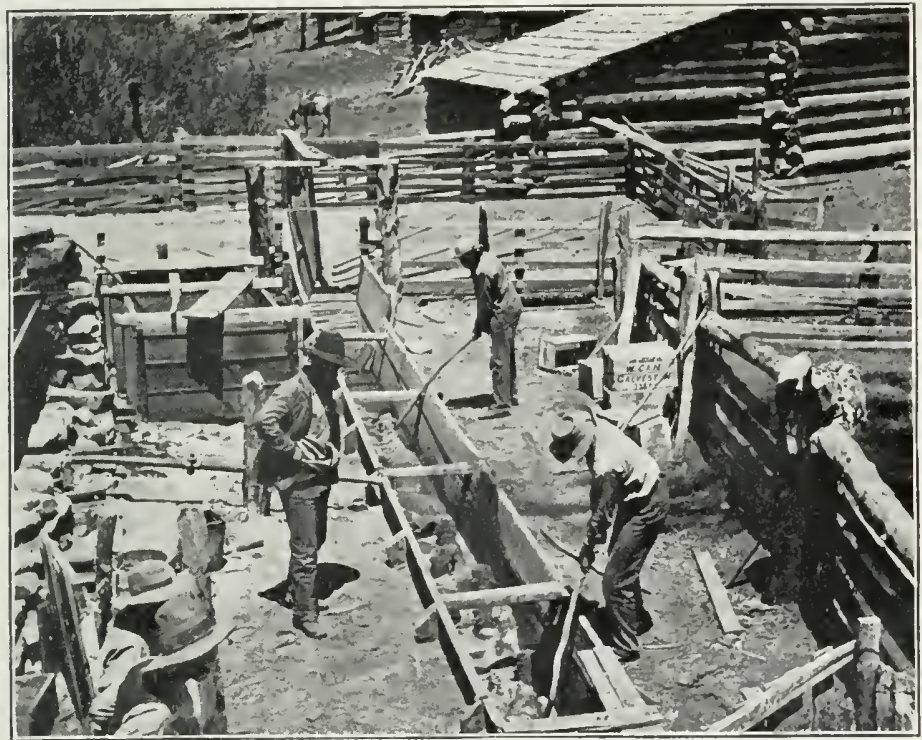

After Being Dipped, the Sheep Fass Through a Dripping Pen at the End.

it is necessary to use it twice at periods of about ten days. This allows time for any nits or eggs deposited on the animals to be hatehed out and killed, as few of the dips will affect them before that time.

The cost of dipping sheep raries according to the dip used, but on an average it costs about 3 cents per head to dip a band wi sheep once. In fighting the dis- 
ease on the ranges it is absolutely necessary that all old corrals and bed-grounds be either burned or disinfected. Posts near such places and also tree trunks where the affected animals may have rubbed and thus left a starter for a new outbreak, should be well treated with.strong solutions of the dip. Like all such troubles it is a case of eternal vigilance, and the wideawake sheepman dips his herd each spring, no matter whether the sheep show signs of the disease or not. The dipping is good for the sheep, they are rid of all ticks and such insect pests for the time and as a general thing the growth and staple of the wool are improved by the operation.

Lip and Leg Ulceration.-This disease is local in its geographical extent at present, being confined to certain well-defined areas in Wyoming and Montana, where it has existed for many years in a mild form, but finally through shipping and moving the herds about, on the ranges, it became epidemic over a considerable area. These areas have been quarantined and by co-operative work between the Bureau of Animal Industry and the board of sleep commissioners of each state is in a fair way to be stamped out.

The disease, like scab, does not always kill the animal affected but lowers its general condition and keeps it in poor flesh. It is a highly infectious disease, sheep apparently picking up the germs on the range as they feed. Ranges having a great deal of cactus, so that in feeding the animals get their lips and noses pricked, are the most dangerous, for the disease seems to be carried from one sheep to another by the deposit on the feed of the pus or discharged matter from the sores, on the animal's body, legs or lips. On such ranges it is difficult to eradicate. 
The symptoms are lameness in one or all of the feet, and the animal shrinks rapidly in flesh. The little sores on the nose and lips and other places discharge an offensive greenish pus, which is characteristic of the disease. It is through this pus dropping on feed that the disease is spread over the ranges.

The disease yields to almost any of the better elass of sheep dips, or to a 1-to-5 solution of water and nitric acid. In some cases the victims can be treated by wading them through shallow pans or dips containing enough of the medicine to cover the hoofs. The only way to get at the sores on the body is to take each animal and doctor it with a swab, taking care to have every sore cleansed of all pus before the treatment is applied. In some serious cases where the animals have been neglected the disease affects the hoofs, and they drop off.

The infection also enters lambs through the freshlydocked tails or the scrotum after castration; in fact, it is ready to locate in or on any wound, however slight. The infection of the body or in such places as are mentioned comes doubtless when the animal lies on the ground. The germ is apparently very tenacious of life, and sheep using a range infected with it must be constantly inspected. At present the disease is not thoroughly understood but it is being earefully studied by Government veterinarians. 


\section{DISEASES OF HORSES.}

It is not possible in a work of this size to give a full and complete list of the diseases to which horses are subject. But we may properly note some of the most common maladies which at one time or another are likely to attack every horse. The fact that under ordinary conditions of use horses are apt to be taken sick at places where it is impossible to obtain the services of a veterinary surgeon makes it necessary that all men who own horses should know something of the best methods to be taken to relieve them when sick.

Of the many diseases to which horses may at times be subject the following have been selected as those most likely to trouble the average western stocknian. In all of these if a veterinarian is to be had, call him in, but if not, study the symptoms carefully before deciding what remedy to use. If the animal assumes unusual attitudes, as sitting up on its hindquarters like a dog, rolling onto its back with feet in the air, or resting on the knees while standing on its hind feet, and sweats profusely, it is safe to look for colic or some trouble with the digestive organs.

If the horse has been standing in the stable for several days, fed full rations of hay and grain and given little or no exercise, it may when led show lameness in one or more legs, heavy sweating, general stiff- 
ness all over, loss of control over the hindquarters, sometimes falling to the ground, trembling of limbs and body, passing ropy and deep-colored urine under considerable strain. It is then safe to suspect azoturia, due to a lack of exercise and heavy feeding.

If the animal's head or neck is swollen to twice the natural size, the eyes almost closed, high fever, no appetite, a tendency to giddiness, sometimes falling, as in a faint, the trouble is likely to be due to a snake bite.

Colic.-Two-thirds of the troubles of horses are due to colic. Veterinarians recognize several kinds of colic: engorgement colic, obstruction colic, wind colic, or bloat, spasmodic colic, and worm colic. To simplify the work of the layman who is called on to doctor a sick horse, I shall reduce these to two heads under which most of the cases will fall.

The symptoms of engorgement and obstruction colic are to the ordinary stockman much the same and the remedies available about the average home or ranch may be used in each case. The stomach has been overloaded, the bowels and large intestines are obstructed and the functions of the digestive system at a standstill. The remedies therefore are similar to those which would be used in the same trouble in the human. Open the bowels get rid of the accumulated mass in the stomach and intestines, and relieve the pain.

Engorgement or Obstruction Colic.-Symptoms: The animal shows it is in great pain, although it may be intermittent in character and at times the animal is apparently not suffering. It rolls, bites its sides, lies flat on the side with feet and head extended, looking back at its flanks occasionally as if there was the seat of the 
trouble; gets up and roams about the stall, then lies down again, sweats profusely at times, switches its tail, tries to urinate frequently; sometimes sits up on its haunches like a dog, or kneels down like a trick horse. Again it will try to roll so as to get on the back, with all four feet in the air. These positions seem to give some case from the pain. Often it groans loudly, as if to show the pain it is suffering.

For the bowels there are many home remedies available, as one pound of Glauber's or Epsom salts; or a pint to a quart of linseed or castor oil with 15 drops of croton oil added; or one ounce of powdered aloes, two drams of calomel, one dram of powdered nux vomica mixed thoroughly. A gallon or more of warm, soapy water administered as an injection twice-at hourly intervals-should always follow any of the other remedies because of the difficulty of reaching the trouble through the stomach.

An entire bottle of Jamaica ginger or any of the various pain killers or cholera remedies that are to be found in almost every country home or store will very materially allay the pain. Dilute them with a pint of water. Do not give all of these remedies at once; do not give a second dose for at least twenty-four hours, as it takes that long for the boweis of the horse to move. Give a full dose at one time rather than two small seperate doses. Don't kill the animal with kindness; give the medicine a chance to work, and the animal a chance to get well. In bad cases the hand and arm may be greased or soaped and inserted in the rectum and the hard pieces of fecal matter removed. This will materially assist the medicines.

Wind Colic.-In wind colic many of the symptoms are 
similar to those of impaction of the stomach. The cause of this colic is over-heating and over-feeding, going without feed for a long time and then being too heavily fed; too much green feed; new hay and grain, especially oats and corn or sour grain or feed.

In addition to the symptoms already given, the belly is considerably enlarged and bloated and if struck in ront of the lips and back of the ribs it gives forth a hollow drum-like sound, due to the accumulated wind or gas. In serious cases there is profuse sweating, intense pains with violent twitchings of the stomacls; trembling of the limbs and staggering from side to side. In fact, the symptoms are quite like those in man when suffering from a bad attack of stomach ache. The sure symptom is the drum-like sound of the stomach when struck, and the tightly strctched skin over the stomach walls.

The same physics should be given, and the same medicines for alleviating the pain as in the other form of colic. A tablespoonful of ordinary morphine or opium will ease the pain. Rub the flanks with turpentine, covering a spot about eight inches across just behind the ribs and rather low down on the body. If the animal is down lay heavy pieces of blanket wet in very hot water on the body, changing them as they cool.

For this colic one of the best remedies I have ever used is chloral hydrate, mentioned in the Government work alluded to on page 284 of this book. This is used in a drench, one ounce to a pint of warm water. See that every particle of the drug is taken up by the liquid, as it is a strong irritant to the mouth and throat. It is an inexpensive material to keep on hand and does not seem to lose strength when kept bottled. We always 
kept an empty ounce bottle for a measure and never failed to get good results from its use.

As it also relieves pain, the use of other drugs like morphine or painkillers is not necessary when this remedy is to be had. One dose generally did the work but in severe cases we gave a second dose after an hour or two, but no more.

In both kinds of colic I have seen excellent results from kneading or working the stomach so as to help the bowels work off gas and accumulated feed. Where the animal is standing on its feet, take a smooth pole. like a pitchfork handle, or a neck yoke, pass it under the animal's belly and with a man at each end slide it slowly back and forth on the belly, pressing upward as much as possible. This will stimulate the bowel action and give great relief to the animal.

Finally, in all kinds of colic, do not over-dose the patient; give the medicines a chance to operate; and remember that, as a general thing, the symptoms of the trouble and the remedies for it are much the same as in the case where a man is treated, only on a larger scale.

Azoturia.-This trouble always puzzles the ordinary stockman. His horse has not been used, has been standing idle in the stable, has been fed regularly and apparently was in the best of spirits when led nut to be used. Yet inside of the first 100 vards or so he began to limp on one or more legs: his fire was all gone: he seemed dull and heavy-eyed; his flanka were heaving and the sweat came from every pore. He seemed unable to use his hind limbs they wabbled as he staggered along and finally he dropped in the road, a pitiful sight. The urine that is passed is rery dark-col- 
ored, being sometimes almost brown or black, like thick coffee. The rictim may die in a few hours or may recover as soon. Again there may be a partial paralysis of the hind limbs which lasts for montlis, and possibly the animal may never fully recover.

The cause of azoturia is overfeeding with rich feeds, as grains, especially oats, cottonseed-meal and alfalfa, with lack of exercise. Where animals have the run of a small lot or barnyard the disease seldom is found. The animals attacked are those confined in close stalls for several days, fed regularly and given no exercise to aid nature in digesting the feed.

Remedies.-In the beginning something to loosen up the bowels is necessary, a dose consisting of four to six drams of powdered aloes or a pound of Glauber's salts being advisable. Follow this with a dose consisting of four drams of bromide of potassium with one ounce of sweet spirits of nitre given every five or six hours. for three or four times, until the nervous conditions are relieved. The bromide quiets the nerves and the nitre increases the urinary secretions. A well-known veterinarian recommends a tablespoon of powdered saltpetre in a quart of water given as a drench.

Get the animal home as soon as possible and give it moderate dailv exercise. keep the bowels open, and cut down the feed to the minimum. If the paralysis of the limbs comes the advice of a good veterinarian will be needed if a recovery is hoped for.

Snake Bites.-Symptoms: If the attack by a snake is seen. the remedies to be used can he applierl immediatelv. but probably nine-tenths of all such injuries take nlace when animals are grazing in pastures and nothing is known of it. A horse comes in with its head or neck 
swollen to twice the natural size; the eyes are shut and running water; there is high fever with dry parched lips; the appetite is gone; there is a tendency to giddiness, the beast sometimes falling as in a faint. Possibly the point where the fangs entered may be seen, due to the small holes left from which the blood or suppurated matter is running.

Where the conditions are so far along very little can be done except to keep the horse up and give it large doses of aqua ammonia, alcohol or whiskey diluted in two quarts of water. These reemdies are simply to stimulate and revive the animal, and give it life enough to overcome the effects of the poison. Opening the point where the swelling indicates the wound or bite to have been made, and letting the blood flow, will do considerable good. A poultice on the opening will also assist in a cure. If the bite is received on the limbs, and is noticed immediately, a ligature or tourniquet about the limb above the place, made by using a handkerchief or cord tightened sufficiently to stop the circulation, should be used. Then with a knife open the wound if it can be found, and allow the blood to flow, being careful to keep it out of any sores or wounds on the hands. In fifteen minutes loosen the ligature a little and allow the blood to circulate for a moment; then close it down again. Repeat this operation four or five times. By this means the poison gradually finds its way through the body and its action is not so deadly. Quart-doses of whiskey or six ounces (a teacupful) of ammonia diluted with a quart of water should be given to stimulate the animal. Few horses or cattle dic of snake bites and in ordinary circumstances will recover in from ten to fifteen days.

Glanders or Farcy.-Many cases of this disease occur 
among horses all over the country, and one cannot be too careful when buying a horse to make certain that it is not suffering from the disease. Again, in bringing valuable animals into contact with other horses it is well to be on the lookout for signs of the affliction. This is especially true in using corrals, stables and feed yards throughout the West, where there is a constant stream of horses coming and going all the time, eating from the same feed-boxes, and watering from the same troughs.

There are two forms of the disease; glanders and farcy. It is called glanders when the disease makes its outbreaks in the nostrils, throat and lungs. Farcy comes in the shape of small ulcers or boils which appear most frequently on the lips, neck, shoulders and inside the thighs, and may also be found elsewhere. These are called farcy "buds" and may be from the size of a pea to that of a walnut.

The average horse dealer and country "hoss" doctor talks of "fearcy" as a trouble quite apart from glanders, and also affects to laugh at glanders, calling it simply chronic catarrh, influenza or cold in the head, and assures one that it is easily cured and not contagious. The truth is that glanders and farcy are one and the same disease. Both are highly infectious not only to horses but to man. Both are incurable, and may exist in an animal for years without causing death, while spreading the trouble far and wide among other horses with which it comes in contact.

If a horse has a bad discharge from the nostrils, keep it away from all other stock, feed and water it separately and in every way protect the others from it. One should be careful how one handles it, as if glanders is 
present the infection from the discharge in a sore on one's hands, or blown by the animal from the nostril into a corner of the eye or a sore on the body, it will convey the disease.

If the horse has small nodules or sores like little angry ulcers inside the nostrils, especially on the division between the two sides of the nose, look out for it. Feel under the jaws on the outside about at the base of the tongue and see if there are several hard lumps there about the size of a hickory nut. Tlisse are the swollen glands and in connection with the discharge from the nose indicate the possibility of glanders. Sometimes when the disease is quite advanced the nose will bleed more or less, which is in itself a suspicious matter. Be careful in investigating the nostrils that the animal does not snort or blow into your face. Veterinarians are unusually cautious in handling this disease and when about it, especially in looking into the nose, will wear heavy rubber gloves and a mask to protect the face and eyes. The gloves should be carefully washed after using in a 2 per cent solution of carbolic acid and water.

In farcy the little buds or buttons that appear are similar to small boils with a discharge of sticky yellow matter of the consistency of the white of an egg and like heavy castor oil in appearance. These sores will often run for some time and then heal over, only to break out on some other part of the animal. The harness or blankets which touch these sores become infected and carry the disease to other horses which may use the same articles.

Where the animal is thought to be suffering from glanders it should be at once separated from all other horses or animals, fed separately, watered in a separate 
bucket and every piece of harness that has tonched it, ropes, halters, bridle, blankets, neckyokes and especially curry combs and brushes, should be carefully washed in a 5 per cent solution of carbolic acid. Whitewash the stalls and all about the stable where infected animals have been with 5 per cent of carbolic acid in the whitewash. A clear wash will be as good but the whitewash shows wherever it has been used, and thus aids in making the work cover every bit of the exposed surface.

Unscrupulous horse dealers do more crooked work with glandered horses than any other disease from which horses suffer. An animal with the disease will be doctored 11 p and worked off on the first innocent purchaser, although in many of the states there are severe penalties for such tricks. There is a certain test for glanders called the Mallein test, in which, by means of an injection under the skin on the anmal's neck, an experienced veterinarian can determine with great certainty from the reaction, whether or not the animal is cliseased. When a horse is suspected, do not buy it until it has been so tested and where it is already your property have it tested yourself.

But above all beware of the man who calls it "fearcy" and says it is curable. 


\section{CHAPTER XIX.}

\section{INSECT PESTS.}

Insect Pests. - There are three varieties of flies which bother range animals throughout the IVest. First in the list is the little black horn fly (Hoematobia serrata) so-called because of its habit of settling in great masses on an animal's head about the base of the horns. The top of the withers is also a favorite camping-place for them. They are so persistent in their blood-sucking attacks that often the base of the horn will be all raw and sore.

These flies were first noticed in the United States in 1887 in New Jersey and later in Maryland and Tirginia. They are well known in Europe and were doubtless imported from there either in dry hides or on live cattle. The report of the Secretary of Agriculture for 1887 mentions them as new arrivals. Now they are to be found all over the Lnited States.

Like all flies, they breed in horse or cow manure, and little can be done to prevent their increase. Gentle cattle, like milk cows, may be protected from their attacks by using fish or train oil as an emulsion to be sprayed over the animals or daubed on with a swab. There are several kinds of patent mixtures on the market intended for this purpose; most of them are based on fish oil and a slight amount of carbolic acid. These are all good and sprayed over the animals every day will relieve them of an immense amount of worry. This is especially true of 
milk cows, whose supply of milk is noticeably increased when the spray is used on them.

Another fly pest is the common serew worm fly (Compsyomia macellaria), a good-sized fly with a bluish green borly and a red front to its head. It lays its eggs in any place where the slightest spont of blood is to be found. The eggs hatch very rapidly, often in an hour, yielding "screw worns." On many ranges great care has to be taken in branding calves, lest they get screw worms in the wound nade by the burning. If a roundup in the mountains is fullowed by a rainy spell, almost every calf that was branded will have to be caught and doctored, or else it will be eaten up by the worms.

If the wound is not too deep, and in a place where she can reach it, the mother will cure it with her rough tongue. Frequently fresh-born calves beconte infected about the navel and die because the worms working inside the body cannot be reached by the cow. A rainy season appears greatly to increase the attacks from screw worms and, as a general thing, it is dangerous to brand calves in the higher ranges during the rainy season. In the Rocky Mountain region this is usually during July and August.

There are several patented preparations for killing screw worns, and on ranges where they are known to be bad every rider carries a bottle of one of them in his saddle pockets, ready to care for any animal he may rum across on the range. The animal must be roped and thrown, and, by means of a little wooden paddle, every worm is dug out that can be reached; then the wound is filled with the medicine. which kills any worms left, heals the sore and keeps the flies from again depositing their eggs in it. Any of the ordinary sheep dips will 


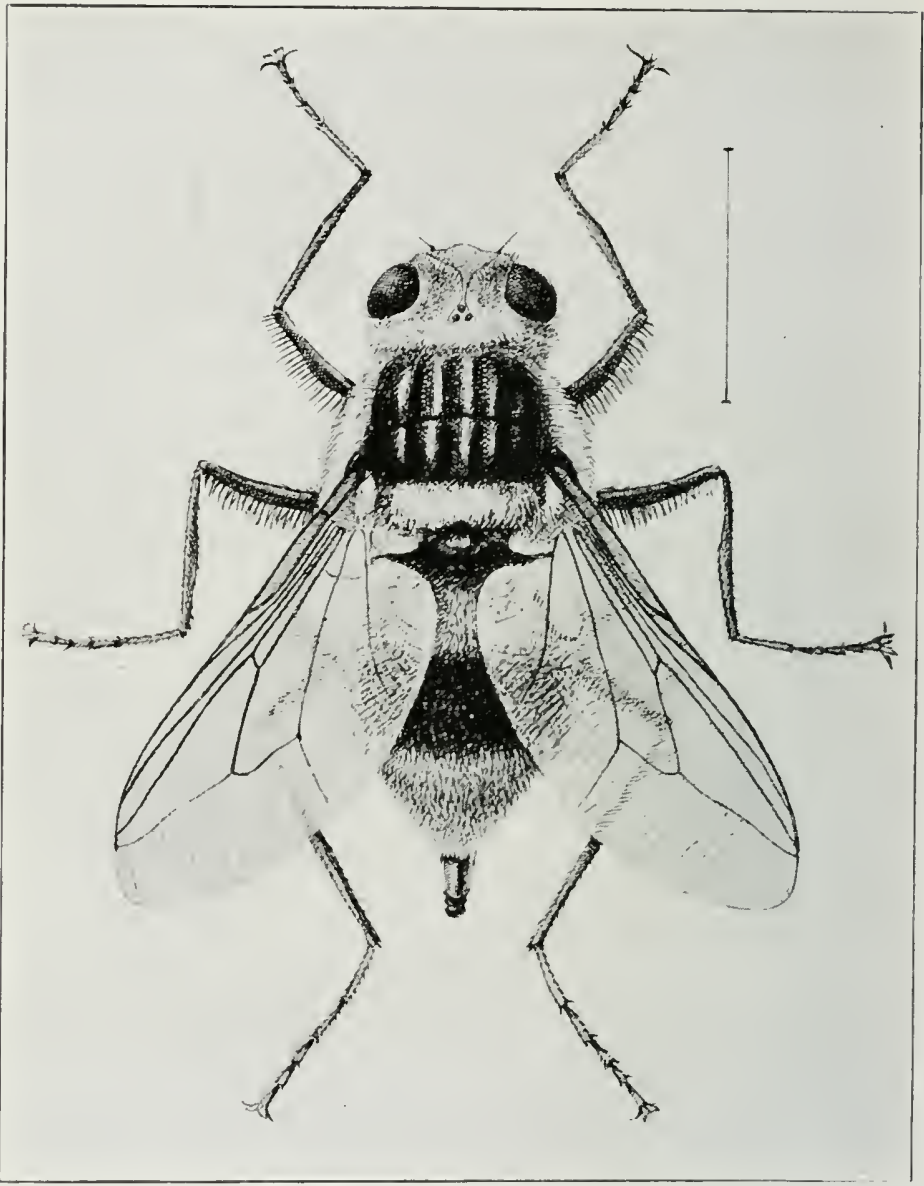

The Heel Fly (Hyporderma Lireata).

kill screw worms. Chloroform is often used, although it is very severe in its action. An animal suffering from screw worms can generally be identified by the little trickle of pale watery-looking blood that discharges from the wound. 
Heel flies (11ypoderma bovis-11. Lineata).-These flies do an immense anonnt of clannage to cattle, both domestic and range, every year. They are also locally known as "bot" flies and "warble flies." They are about half an inch long and resemble ordinary honey bees. In March a rider will see a bunch of cattle all "shaded up" under a bank or a tree and standing quietly. Suddenly

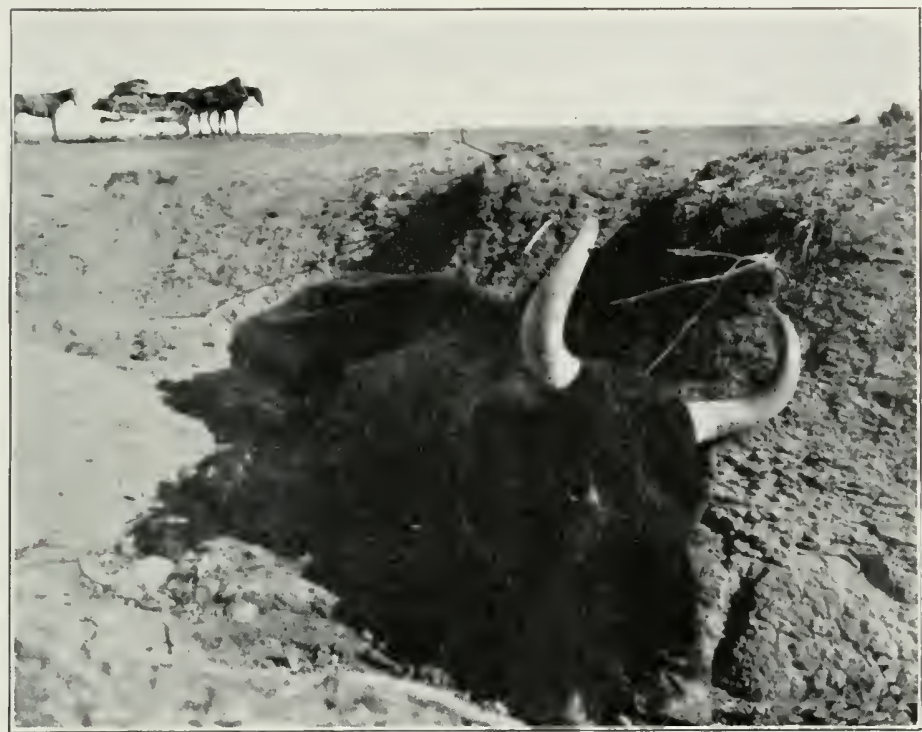

A Bogged Down Cow Overlooked by the "Bog Riders."

out darts a cow, tail and head high in the air, a wild look in her eyes and kicking out vicionsly with her heels. She charges at full speed for the nearest waterhole, into which she plunges as deep as she can. It is "heel fly" season in that ricinity and many an old weak cow finds her final resting place in some sticky mudhole, driven there to escape the attacks of this fly, too weak to drag herself out again. 
The supposition is that the heel flies sting animals on the heels or hind legs. They also trouble horses but seem to attack them only in front, and a horse will strike out vigorously with his front feet and go almost crazy over a single fly. Time after time have men placed their hands where the heel flies could strike them, but I never knew anyone to be stung or feel the least pain or pricking from the touch.

The heel fly is known to fame as the fly that brings the great "warble grub" in the backs of cattle. There are many skeptics as to the warble part. The activities of the heel or bot fly are confined to depositing its little yellow eggs on animals. These one can easily find, as they are deposited on the hairs of the shoulder or neck and chest just back of the shoulder, low down on the ribs. From there they are taken into the animal's mouth, as it licks itself. It would seem that the instinct of the insect led it to lay the eggs in those places which can be most easily reached by the animal's tongue.

Once in the animal's body, the egg hatches out, and the grub works its way through the flesh and finally locates under the hide and between it and the flesh on the back, generally forward of and between the hip bones and shoulder blades. There it rests, growing rapdily. finally forcing a little hole through the hide, out of which it eventually passes and drops to the ground. The grubs can readily be discovered by feeling over the animal's back for the lumps which they form. With a little pressure on either side of a lump the grub will pop ont of its resting-place through the little hole, doubtless very much to their host's relief. By means of an ordinary oil can, such as is used by mechanics, a little turpentine or coaloil squirted into the hole will also destroy the grub. 
It took scientific men a long time to convince stockmen that this is the way the huge warble grub finds its way under the hide of a steer or cow, and there are those who yet doubt it and belicre that the grubs are deposited directly in the animal's back by a large horse fly, almost an incli long, that is found all over the country, and which has a bite like a pair of red-lot pincers. But the scientists did not make the statement until they had carefully investigated and studied the subject, and felt very sure of their deductions. The tiny hole made by the warble grub is estimated to cost stockmen millions of dollars every year through the injury to hides resulting from the holes, and apparently there is no practical way to prevent the loss, so far as range stock is concerned.

IVestern stockmen believe very generally that many a sore-backed horse obtained the start for its trouble through a warble in its back, which grew there while the aninual was not being used, and then when saddled up it quickly developed into a bad sore. The scientists believe, however, that the heel fly develops the warble only on cattle and not on horses.

In the high mountains of the 11 est, "deer" or "green head" flies make life miserable for all four-footed animals for a few weeks in the hot weather each year. Fortunately they thrive only in dry weather and with the first rains are gone. June is generally the worst month for them, and during that time all grazing animals, both wild and domestic, lose flesh rapidly because they cannot feed or rest, utilizing nearly all their energy fighting flies from daylight until dark. Saddle animals or milk stock can be protected by any of the fish oils rubbed or sprayed over them.

Take a piece of bacon rind in the morning as you 
saddle up, and rub your horse's head, shoulders and neck with it, if you have not the regular prepared oil to use, and the flies will give him peace for that day. Some horses suffer more than others from their attacks, a white animal seeming to be an especial object of their attentions. On the round-ups or in pastures where horses are running loose, a fire of green wood that makes a heary smoke will bring every animal in from feeding to stand in the very thickest of the smoke all day long and thus obtain some slight relief from the pests. A darkened shed or stable will also give them much protection. The Indians always keep a smudge fire burning during the fly season in the mountains to protect their ponies. 


\section{PREDATORY ANIMALS IN THE WEST.}

No book on the western stock business would be complete without some mention of the various kinds of animals which prey on the stockman's herd. While each class of stock suffers to a greater or less degree, the sheepman is probably the heaviest loser. It is impossible of course to accurately estimate the losses caused by such animals, but it is scarcely stating it too broadly to say that each year the stockraisers of the United States suffer a financial loss of mure than $\$ 5,000,000$ from this source. These figures were obtained by taking an average of the known losses from such animals in specific cases and thus securing definite information as to the damage done by the various animals. For example, a conservative estimate made by well-posted stockmen places the damage done by each full-grown wolf at $\$ 1,000$ per year; for a coyote, $\$ 100$.

Coyotes.-In 1911, 6,487 coyotes and 241 wolves, as well as hundreds of bear, bob cats and the like. were killed by forest officers within the boundaries of the various National Forests in the United States, whose area covers perhaps about one-third of the grazing lands in the WTest. Probably three times this number were killed by private parties during the same time.

The predatory animals of the United States are coyotes, wolves, bear, wild cats or bob cats, mountain lions (congars), and lynxes. Of these the coyote is far 
and away the worst enenly of the stockraiser. Moreover, it is not repulsed by civilization, as are the other animals in this class.

The settling up of a country generally leads to the rapid extinction of almost all the wild animals, unless they are carefully guarded by law. The coyote, on the contrary, rather enjoys the coming of the settler, makes himself very much at home with him, raises its young

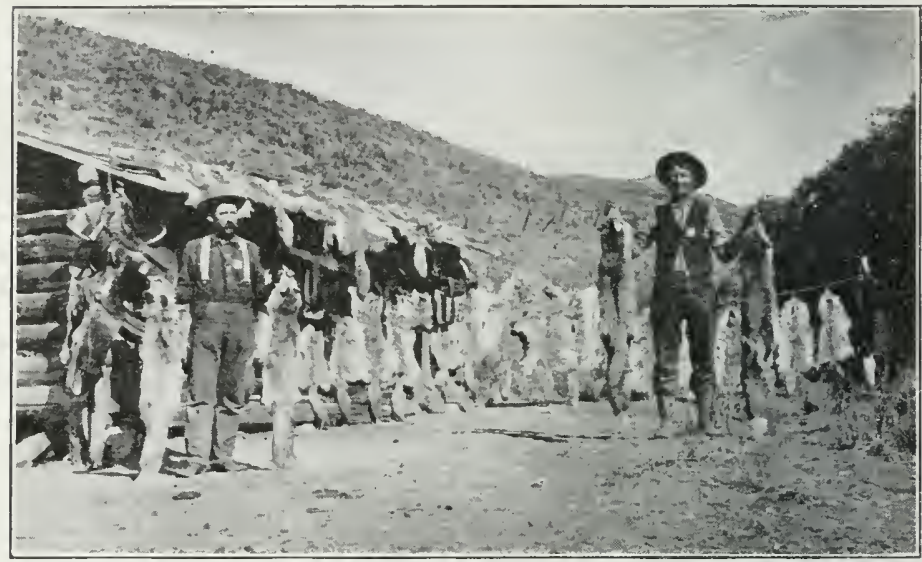

The Camp of Two Government Hunters in the Boise National Forest.

right under his nuse and, in spite of bounties, poison and traps, manages to increase. In the spring, it follows the sheepmen's herds up into the mountains, there to prey on the little lambs or even the older ewes. In the fall it comes down with them and winters close to the farmer's feedlot and chicken coops, or moves along to the winter ranges of the sheep.

The coyote takes an occasional meal at the cattleman's expense too, when it finds a small calf lying under the shelter of some bush, where it has been left by its 
mother while she grazes or goes to water. But the sheepman's lambs and the farmer's poultry are the coyote's chief sumres of food. The animal is a good feeder and, when other provender is not to be had, will hunt jack rabbits or prairie dogs. Some years ago California paid a bounty of $\$ 5$ per head on coyotes with the result that over 75,000 scalps were turned in to the

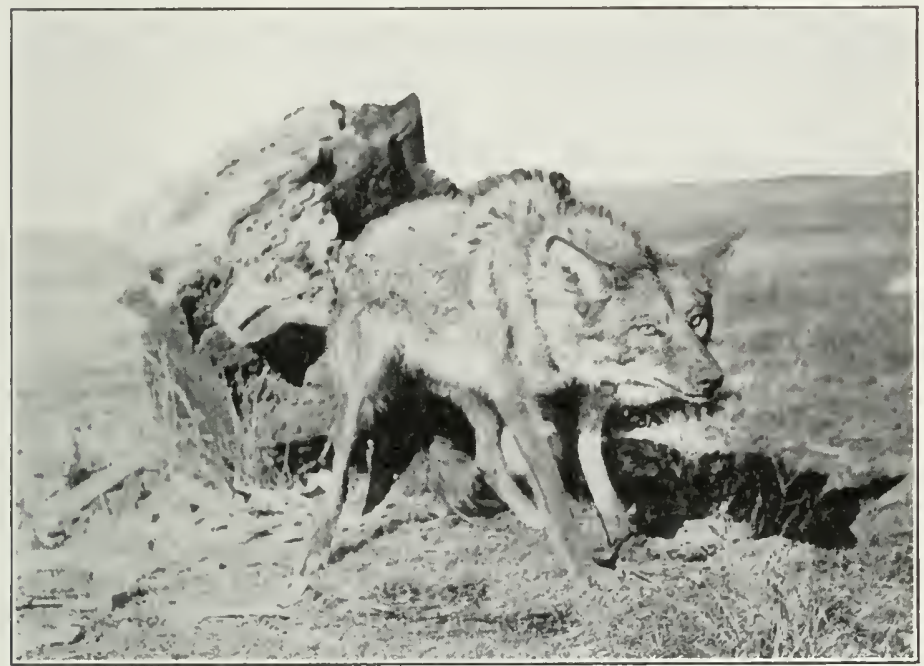

A Coyote in a Trap.

state authorities within the first year. Then the law was repealed by a unanimous vote. In a year or two California farmers began to complain of the increasing numbers and depredations of the jack rabbits. Careful investigations by well-posted men proved beyond doubt that the increase of jack rabbits was largely due to the decrease of their greatest enemy, the coyote. Thus nature seems to maintain a balance between the species. 
The coyotte breeds rapidly, the average litter being between six and nine each year.

Wild Cats and Lynxes.-Next to the coyote the wild cat and lynx, commonly known as "bob cats," cause sheepmen much loss. Unlike the coyote these animals seem to kill for the pure lust of blood-shedding. In an Arizona sheep camp some years ago a single wild cat killed ninety sheep in one night. None of them was eaten or injured beyond having the throat torn open by the sharp teeth of a cat, which was treed by the dogs early the next morning, and killed.

Wild cats and lynxes are easily exterminated both by traps and by hunting them with dogs. They are not dangerous animals, and I have seen quite as many killed by being chased into trees and there knocked out by rocks and clubs and beaten to death as in any other way.

Wolves and Mountain Lions.-These animals do more damage to cattle and horses than to any other class of domestic animals. Neither of them seems to prefer the taste of mutton but both are fond of horse flesh and beef. There are places in the Rocky Mountain region where, due to the inroads of lions, it is almost impossible to raise horses on the open ranges, as the lions kill the young colts as fast as they are born.

The lion is very shy in its way, keen of scent, hard to trap, but rather easy to capture with hounds. Its principal diet when available consists of colts and deer. They, too, like the rest of the cat family, are cowardly and will not fight, unless cornered.

The wolf, however, is the most dangerous enemy of the cattleman. Like wild cats, wolves seem to kill for the pure lust of blood, as well as for food. I have known a single male wolf to kill sixteen yearlings in one night 
in a morthern New Mexico pasture. Not one of the animals was touched, the wohes foing no injury except to tear the body somewhere to let out blood to lap. The wolf is one of the hardest of the wild animals to capture, either by traps or puison. The ingenuity of the animal in evaling traps set by the most experienced trappers, or poison placed with the greatest care and cunning, is

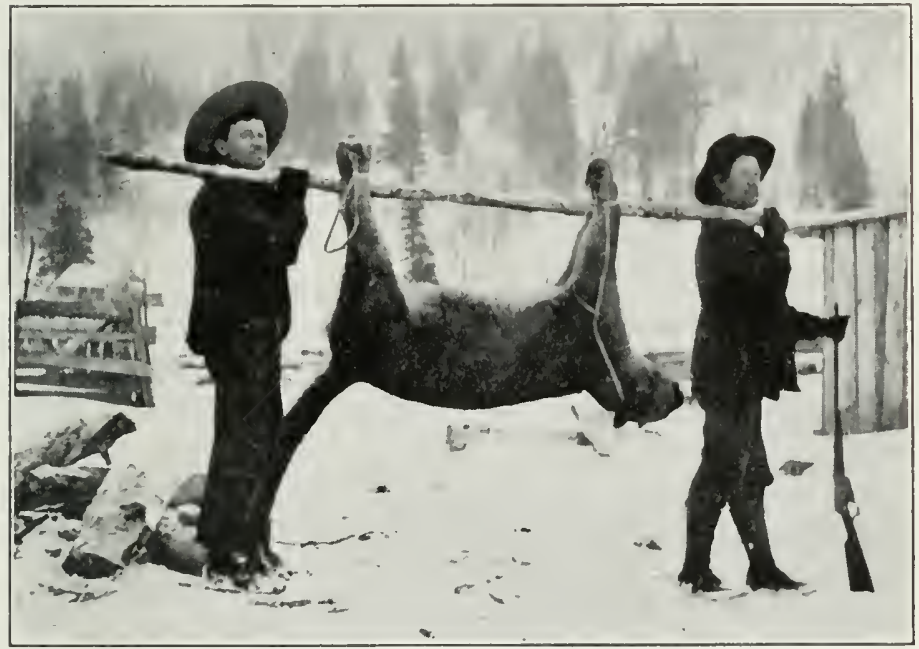

"The Lion is Difficult to Trap But Easy to Capture with Hounds."

almost beyond belief. Nolves will travel the roughest places so as to leave no trail, while their scent is so keen that it is almost impossible to place a trap or poisoned baits without leaving some scent of the trapper that they will detect and profit by.

Fortunately the wolf, wnlike the coyote, does not thrive with civilization, and with the settling up of the country it gradually declines in numbers until but few are left. In such circumstances they are unusually keen. They 
will travel in pairs, often going twenty-five miles in a night to make a kill, and return to their dens before daylight. A pair of wolves located in the breaks along the Red River in northern New Mexico some years ago and raided on the cattle for twenty-five miles in every direction. At first from the damage done it was supposed there was a large band of them, but eventually by the trails it was determined that there could not be more than four of them at the most. Every stockman in the region was on the lookont. The orders given to the cow. boys were to drop everything, no matter how important it might be, and go after that bunch of wolves, if ever they were sighted. Besides the territorial reward of $\$ 20$ the stockmen offered $\$ 100$ extra for each grown wolf scalp taken in that country, with $\$ 10$ for every pup.

Poison was scattered over the whole country until about all the dogs within reach had been killed. Traps were set in every trail and wash wherever the wolves had left a footprint, and the few dogs not poisoned were some of them caught in the many traps which decorated the landscape. Finally one of the most experienced "wolfers" in the whole region was called from some distance to try his hand. He spent a week studying the country, sitting for hours on top of the high peaks watching with a powerful glass every moving thing below him. The first peep of daylight found him up on some cliff or peak listening for the howl of a wolf. Finally one day about sunset he drove a burro down into a small flat below a cliff and shot it, then he rode up to the body of the burro and dropping a piece of dry rawhide on the ground stepped with the utmost care from his horse to the hide. He drew on his hands a pair of new buckskin gloves and with his knife cut from the burro's hind 
quarter a piece of flesh. To several of these pieces he tied with a light threal about six inches long a dose of strychnine done up in tissue paper. Ilis idea was that the wolf was able to detect the smell or taste of the poison when placed in the meat, but by wrapping it in tissue paper and then attaching it to the bait it would follow the meat down the animal's throat with none of the bitter taste of the poison, and thus get clear down into the stomach.

When poison was placed in the meat he believed the animal tasted it as it went down and was able to eject it before it reached the stomach. All this time he did not leave the piece of hide or touch a thing that was not absolutely necessary. Having arranged everything to his satisfaction, he mounted his horse, stooped down and took up the piece of hide and left the place. The next morning at daylight we found the dead wolf not fifty yards from the burro. It was the male and the trapper spent three days more locating its partner. She was finally found in a den so situated that after traveling over a trail for some time she could step off onto a rocky ledge and then drop off a little bench to where she had found a lair so nicely hidden that even within ten feet it was hard to see.

Having located her den he watched from a safe distance and shot her as she came in from a foraging expedition with a jack rabbit for her little ones. In the den we found twelve pups, two of which were taken to the ranch and raised on milk. They became the most playful of pets.

These two old wolves were known to have gone twenty-five miles in a night to make a killing. That they were the evil-doers was proved by the fact that with 
their extermination the losses of cattle in that vicinity from wolves ceased.

The average litter of a wolf is between eight and ten, so that they increase with tremendous rapidity, if allowed to breed.

Bears.-Bruin, which is probably considered one of the worst of all predatory animals, is more the victim of a bad name than of its own acts. While there are cases where bears are responsible for the death of cattle and sheep, as a general thing, considering their numbers, they do not do any great damage. Here and there a bear will be found that, like a sheep-killing dog, has learned the taste of mutton or pork, and makes heavy forays on the stockman's herd.

Occasionally a cow will be found deep in some mountain canyon which, by the signs, has undoubtedly been pulled down by some bear, and a few mouthfuls taken from her flank or legs; but these are individual cases and not general. The sheepman is often damaged by a bear that comes snuffing about the corral some night, more likely looking for something in the camp than anything else. Its strong animal odor fills the air and the frightened sheep stampede across the pen and pile up in their mad rush and smother one another.

It is unfair to class the bear as a predatory animal in any sense, especially the black and brown bear, which do little harm either to man or beast, beyond robbing some camper's outfit of sugar and bacon. Apart from the giant grizzly, the average western stockman does not believe in classing bear as pests to be slaughtered as fast as possible, but he is willing to have them preserved and hunted as game animals.

The grizzly is of course a dangerous animal, to be 
aroided unless one is ready for a fight; hence, it should be exterminated as rapidly as possible.

Trapping and Poisoning Predatory Animals.-For wolves or mountain lions the best trap is a double spring No. 4, with an extra heavy chain; for coyotes and wild cats a No. 3 will be strong enough. The best results will be obtained if the trap is not fastened to a stationary object but to some heary block of wood or a rock. If, owing to the nature of the country it is best to fasten it to some stationary object, there should be a swivel in each end of the chain, lest the animal in its turning and twisting winds itself up until the chain is all tied up and there is n1ore or less possibility of the captured animal escaping.

If a clog is used, wire the chain to it by taking some light wire like a piece of No. 12 or 14 telephone wire, or even baling wire, passing each round of the wire through the link of the chain and abont the clog, so it will not slip off. Fewer aninials will escape from traps fastened to a movable object than to something stationary. The trail left by the drag is easily followed, and even if the clog eventually gets caught in some tree root or brush, the animal by that time has become so tired that it is unable to make much of a struggle to escape.

Beaver, mink and muskrat and other similar animals will gnaw their feet off to escape, unless the trap is set so as to pull them into deep water as they struggle and thus drown. I believe none of the larger animals, like wolves, coyotes or cats, will do this.

Traps should always be set so that the animal in order to reach them must approach from a certain side; that is, by setting it with a log or stone at the rear, or between two logs, so placed that the trap is at the sharp end of 
a $\mathrm{V}$, or in a trail where it passes between two stumps or stones, so that the animal must under ordinary conditions pass over it. If a bait is used do not place it on the ground; hang it up so that the animal as it approaches will naturally be looking up and thus take no notice of what has been placed so cunningly for it to step into. For bait a freshly-killed rabbit or young chicken, prairie dog or almost any wild bird split open and hung over the trap will be satisfactory. Many trappers use no bait at all but depend entirely on scent to bring the animal to the trap. The scent excites them and they paw and dig about the trap and finally get caught.

Set the trap flush with the ground, burying the chain and everything of a metal nature so as not to be visible. Spread a small piece of paper or a few leaves over the pan of the trap, and then sprinkle enough soft dirt carefully over it to cover it. A handful of soft grass will answer the purpose also. Leave everything about the trap in as near its original condition as possible. Don't spit on the ground, smoke or throw cigarette stubs about the vicinity.

If the trap is set near to the house see that the dogs are tied up carefully; also the house cats. It is astonishing how far afield these domestic animals will go, especially in the country. I once knew the pet milk cow at a ranch to be caught by the tongue in a huge trap set for a mountain lion. A handful of grass was strewn over the trap and it is supposed she was attracted by the scent used or by the grass, and in licking about the spot her tongue touched off the trap and she was captured. The chase she led the boys with the trap fast to her tongue and a twenty-five pound club dragging over the ground and the fight that followed when they tried to 
take the trap off will never be forgotten. Moreover, by the time she was discovered she was distinctly "on the prod" and had to be roped and tied down before she could be relieved of her unwelcome burden. Her tongue was badly lacerated but she eventually recovered.

Scents.-Many professional trappers use scents of various kinds to attract animals. Several scents are manufactured and for sale by druggists and others, but the average trapper makes his own from some formula to which he ascribes great virtues.

One of the commonest methods of making a scent is by taking a wide-mouthed bottle like a fruit jar, and placing in it a piece of beef or meat of almost any kind as large as one's fist. Set the bottle in a warm place, out of the rays of the sun for two or three weeks, until thoroughly decayed; kcep the top on to retain all the odor from the decaying meat, opening it occasionally to let the gases escape; then add a quart of sperm, or neat's foot oil, or any animal oil that is available. The oil made from half a dozen fat prairie dogs is unusually good for this purpose. Skin them and try out the fat in a fry pan; to this add one ounce of pulverized assafoetida and one ounce of castoreum or the common musk, sold in drugstores for perfumery. Oil of anise is also good.

Many trappers take the bladder from a female coyote or wolf and use its contents in the mixture, believing it unusually attractive to the animals. Bottle this mixture and use it in a smaller bottle when needed. After setting the trap scatter the scent about the place by means of a little stick or straw so as to get it on the ground near, but not directly on the trap, as the first thing an animal does is to roll in the scent and thus it might set the trap off and not get caught. 
Poison.-The only poison that is successful with such animals is pure sulphate of strychnine. A dose large enough to kill a coyote or wolf is easily measured by taking the large blade of a pocket knife and thrusting it into the bottle of poison. TWhat will easily ride on the end of the blade, say for half an inch, will be sufficient for the purpose and not enough to cause the animal to vomit.

Strychnine is bitter to the taste and must if possible be placed so as to get into the animal's stomach before the taste is detected, otherwise it is rejected.

There are several ways of preparing baits. Fat bacon cut into inch-squares makes an excellent bait. Fresh liver, kidney or meat of any kind, cut into pieces somewhat larger, will do, but these are apt to soak up the bitter taste of the poison and not be quite so efficient. Take these pieces of meat and with a knife open a little pocket hole down into the center of the piece. Into this slip the poison and carefully close up the gap. One of the most successful plans is to dip each bait into a pot of hot beef tallow, which gives it a coating that effectually covers the bitter taste of the poison and is also very attractive to the animal.

If you desire to make a "drag" to toll the animal to the trap or poison, make a bucketful of these baits and, having procured a piece of old beef, a fresh raw hide, or killed a jack rabbit and split it open, or even take an old coat, or banket. and dose it well with the scent. fasten it to a saddle rope and, mounting a horse or riding in a wagon, pull the drag behind on the ground. Drop a bait occasionally where the animal following up the scented trail will find it. In making the "drag" it is well not to follow a road or trail but "ather to cut across 
several trails and roads, as the coyote is specially fond of following down a trail in the soft dust and coming to the scent will immediately turn off and take it up.

Make drags so they can be followed the next day, and you will probably pick up a dead animal or two. Sometimes the animals will drop inside of ten feet and again they will go a long distance. It is due no doubt to the condition of the animal's stomach. If the stomach is full when the poison is eaten it acts much slower than when it is empty.

Where domestic animals are likely to be caught the baits should be dropped at certain places and carefully gathered up the next morning by count, to be sure none is left out. It is ahmost impossible to get a mountain lion to take a bait of any kind. A young colt is the most attractive bait to it. If a foal can be found freshly: killed, by poisoning it in various places and also making a few baits from the flesh and dropping them on and near the body, one may catch the lion. But it is very shy and wary of either traps or poison, due probably to its exceedingly keen sense of smell.

Prairie Dogs.-These may not be called predatory animals in any sense of the word, but as they are a range pest and do a lot of damage each year to the stock interests they may as well be considered under this head as anywhere else. Probably there is no other animal in the region west of the Missouri, that attracts more attention from those new to the country than these little animals. Yards of rubbish have been written about them; how they divide up their residences in the earth with owls and rattlers; how a village of them is a sure sign of water below the ground, because, forsooth, "they must have water and so dig for it." Certainly it is true 
that one of the common sights in a dog village is an owl, generally one of the small species, perched on top of the dirt thrown out by the dogs. Again, it is even more true that many a rattler is found in the holes or prowling about in the vicinity of the villages. They are there, however, not as welcome guests, but like the lion, "seeking whom they may devour." In this case it is the young dogs they are after. Both rattlers and other snakes find many a meal in the prairie dog holes, when the young dogs are small enough to capture.

Another venerable story about prairie dogs is the one which endows them with the wisdom to watch a snake crawl into a hole and then push dirt in the entrance with their noses and thus seal his snakeship up in a tomb, the victim of his own gluttony. I have carefully watched a dog hole for hours to see if anything happened when a rattler crawled lazily down into it. All that did happen was the hasty scuttling out of the dogs which were caught in the place and their taking up a position on a nearby mound and hurling all sorts of unkind remarks at their unwelcome visitor in their little piping voices. As to any efforts made to secure revenge, there were none, nor do I believe it was ever done.

As for the water theory (and I have heard old-timers vouch for its truth), there appears to be absolutely no foundation for it. Prairie dogs use but little water. Like rabbits, they secure what moisture they need from the roots and grasses on which they feed, and can go for days without any actual drinking. If one will only stop to think one will recall many a village located on spots where from the very nature of the country, an underlying layer of rock for instance, water could never be found by even the most improved methods of well dig- 


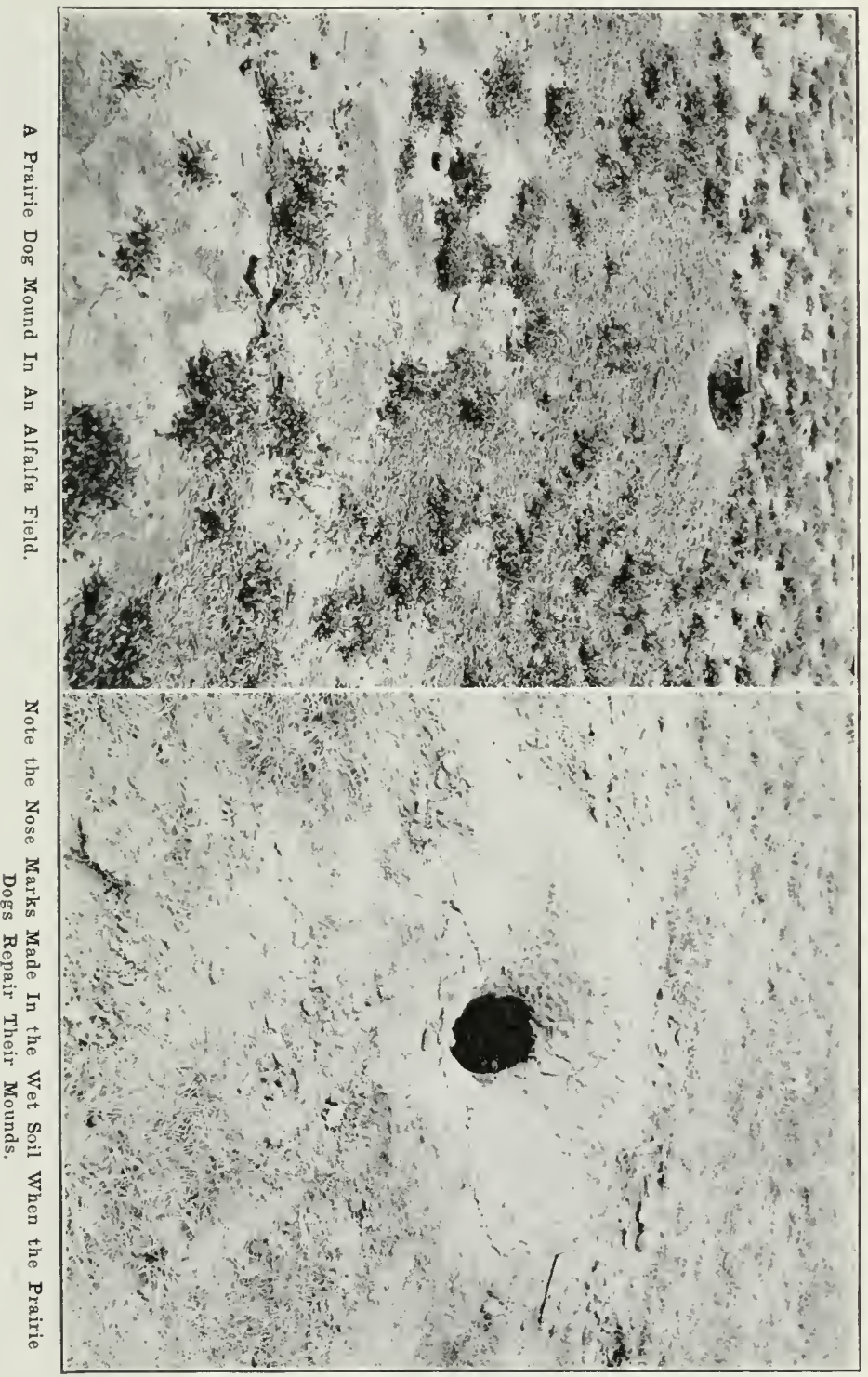


ging. Moreover, hole after hole has been dug out with great care, and as a usual thing they seldom go down into the ground beyond four feet and some of them not more than two and a half. The dogs show considerable ingenuity or instinct, however, in the digging of their holes. Almost all of them are so constructed that the nest in which the young are born is some higher than the lowest place in the tunnel leading down to it; that is, the dogs dig down for some distance and, turning the tunnel up a little, probably a foot, the bore is widened out into a little room or chamber where the nest is located. If this is done for anything at all it is done to give the water that naturally runs down into the holes a chance to settle and not drown them out.

Another piece of work which is creditable to their instinct is the banking up of their monnds after a heavy rain. No sooner has a rain ceased than the whole village is at work chattering and barking like a lot of children at play. With their noses and front paws they roll up little balls of wet earth, pushing them ahead up the mound. Using their noses for trowels much as a beaver does his tail, they skillfully plaster the wet earth about the entrance so as to raise the walls and repair any damage done by the storm. When the mud has dried the print of their little noses and feet where they have patted it into shape and molded it together is plainly seen. Any one who has lived in a Mexican village will recall seeing the old women and boys at this very same sort of work after a rainstorm. Like the dogs, as soon as it has cleared off out they come and, using the mud made by the rain, they roll up little balls and proceed to patch up the adobe walls where the rain has eaten into them. Like the dogs they also keep up a constant chattering and gabbling. 
The ravages of the prairie $\log$ on a range are well known. The experts of the United States Biological Survey after a careful study of the question estimate that 250 dogs will consume as much grass as one cow and 32 will equal one sheep. The effect of their work is easily seen about any of their villages, for the grass and everything living is cleared off for some distance around each hole as if clone with a hoe. As soon as one vicinity is well cleaned up, the dogs migrate to a fresh spot, thus carrying their devastation over a wide range. On such a spot the grass comes lack very slowly. There is a short wiry grass which comes first, known locally as prairie dog grass (Aristida fasciculata), which nothing will eat except when the leaves are young and tender. In time, however, with a few good years of rainfall, the cleared spaces about the village again resecds and eventually the old grasses come into their own.

I know of one such place, a pasture covering several thousand acres, where all the dogs were poisoned out, and in about eight years the grasses had all reseeded and the range was quite as good as ever, barring the holes, which were still there-pitfalls for the unwary cow ponies. Of late years stockmen have given the question of the extermination of these pests much attention. Down in the Texas Panhandle the situation became so bad that the stockmen set to work to clean them out. After a few experiments it was found that it could be easily done through the agency of poisoned wheat. The state of Kansas also took hold of the matter, and in two or three years spent about $\$ 100,000$ fighting the dogs. Whole counties there were almost useless for stockgrazing purposes, while damages to farmers were almost 
as great. The result of the campaign was that the ranges were practically cleared of prarrie dogs, and with a little watching they have not again obtained any foothold worth mentioning.

The prescription given here for the preparation and use of the poison for this work has been used all over the West, both by stockmen and the United States Forest Service. 71 ith wheat at $\$ 1$ a bushel and strychnine at the same price per ounce, the cost of this poison by the bushel will be around $\$ 5$. I bushel of wheat will make about 4,000 doses.

Poison for Killing Prairie Dogs.-For one bushel of wheat take 3 ounces of sulphate of strychnine; $1 / 2$ pound of cyanicle of potassium: l teaspounful of oil of anise, and 2 quarts of molasses. (The heary New Orleans molasses is the best.) Put the strychnine into one can and the cyanide into another; add one quart of water to each; put over fire and bring to a boil, stirring so that it will dissolve. Care should be taken not to inlale the fumes of the cyanide. The strychnine will seldom dissolve complately. Pour the two into a can large enough easily to hold two gallons: add two quarts of molasses; put on the fire and bring to a boil. Set off, allow it to cool a few minutes, pour in oil of anise and stir thoroughly. Then pour the mixture over the wheat a little at a time, stirring the grain as you pour the mixture over it, so that every individual grain will be coated. Set it aside for a couple of hours to dry, put in boxes, barrels or sacks, and use as desired. If it is to be hauled or shipped, use double sacks to avoid danger of leakage. A few quarts of bran or cornmeal scattered in the wheat as it is stirred will keep the grains from sticking together or balling ap. 
Do not think when you start in that this mixture will not go over a bushel, for you will find it ample. An iron tub to mix the wheat in or a box such as plasterers use in which to mix plaster is most satisfactory. Stir it with a shovel, mixing it carefully through and through, as you pour in the mixture. Be careful where you put

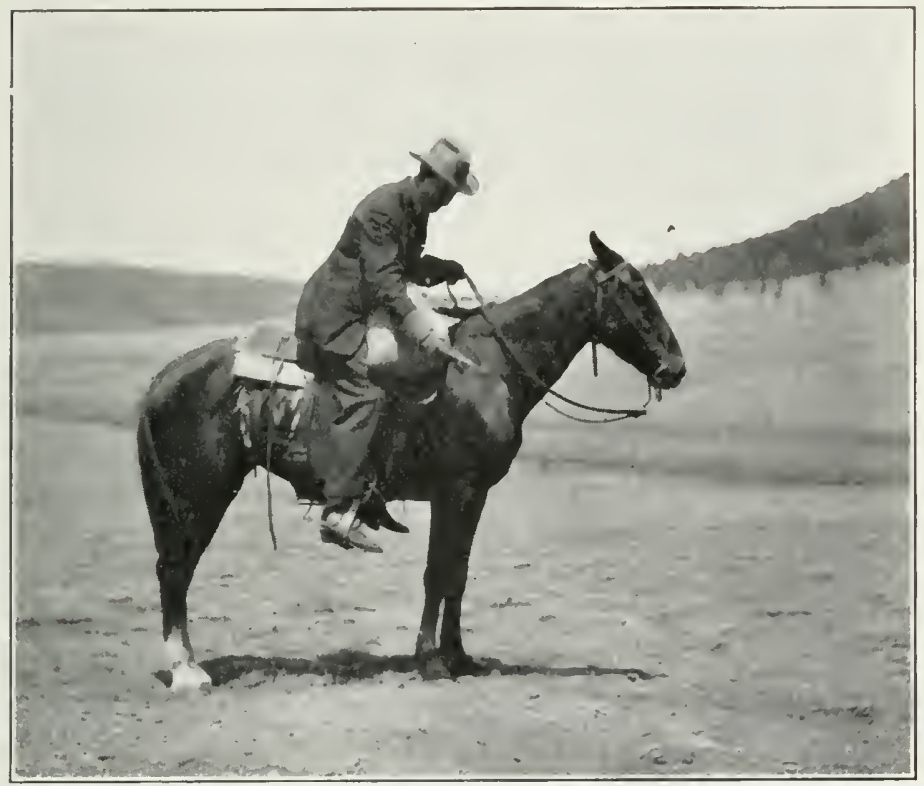

Distributing Prairie Dog Poison.

the wheat after this. Pet horses, pigs and any number of chickens have been killed by leaving the tub exposed with the wheat in it. After you are all through, take an ax and chop up every utensil used excepting the shovel and burn them, so as to make sure they will never be used again for other purposes. 
The best time to use the poison is in February, March and April. The dogs are then hungry and will eat anything. As soon as green grass comes they are not so apt to eat the wheat. The best plan for using it is as follows:

Take a light wagon as a base of stpplies; put into it about four bushels of wheat; drive out on the range and, beginning at a definite point, work a regular system of covering the country. The driver can leave his team in the middle of a thickly settled village and, taking a bucket and teaspoon, drop a spoonful at each hole, from one to three feet away, and always on the same side of the hole. This prevents duplication of doses. The rest of the party on horseback, each with a bucket of wheat and spoon, rides rapidly from hole to hole in the scattered places, working up to certain trails, roads or other natural boundaries. It is surprising how rapidly one can cover a country. One can keep a horse on a good jog trot and fire the wheat with unerring aim at the holes and not stop moving unless the holes are too thick.

Nothing seems to be gained by placing the wheat in the holes, as from experience in its use the dogs seldom eat it when thrown inside the holes. A most convenient way to carry the wheat for this work is to take a gunnysack and sling it over the right shoulder, resting it on the left hip; then slip a ten-pound lard bucket into it in which to carry the wheat. This leaves the left hand to guide the horse, and the right to use the spoon. Three men can easily put out four bushels a day, or 16,000 holes. They work across the country and back, just as a farmer would sow wheat. Sometimes stakes set up for guides are of assistance. Select a period of pleasant 
weather if possible, as wet snow or rain weakens the poison. It acts at once. Dead dogs have been found in thirty minutes from the time the poison was distributed. You will find lots of them on the ground and, of course, the largest number are dead in the holes. You may also get a number of skunks and badgers.

In a month after a storm ride over the country again and whenever you find signs of the dogs leave a fresh dose and you will surely get them. It is well to watch the ranges during the summer, and a year later work over the same area, and with another dose spot the holes that show signs of occupancy. 


\section{SADDLE HORSES ON THE RANGE.}

In selecting a horse for range work one must be guided more or less by the nature of the country in which it will be used, and the weight it is expected to carry. If intended for mountain work with considerable climbing up rough steep trails, to carry a man weighing more than 160 pounds, the horse should weigh not less than 950 pounds. A good all-roind weight is 1,050 pounds in good flesh. For work on an open prairie country an animal of less weight will be satisfactory.

One of the toughest little cow ponies I ever knew weighed but 850 pounds when hog-fat, but he could climb the steepest mountain and carry the heaviest man equal to any horse in the outfit, and he kept it up till he was 21 years old, when he was honorably retired.

A small light-weight horse will not knock himself out in the knees so soon as a heavy animal will. He will also pick up more quickly on the range, get about better with hobbles and take less feed to keep in equal condition.

Type of Horse for Range Work.-For general allround range work, on every kind of country and taking his chances for feed as he hobbles about at night after the day's ride, get a short-coupled, round-barreled animal, with good stocky legs, the front pair coming out of his body wide enough apart to give lim plenty of chest 
room, a short neck, clear kindly eyes with plenty of room between them, small well-set ears, broad open nostrils, withers not more than an inch higher than the hips, hips well-rounded, not sloping down like the steep roof of a house, tail carried high and coming out of the body well up on his hips, hoofs solid and well shaped and not taking more than a number one shoe, weighing fat between 875 and 1,000 pounds, not pigeon-toed-for such horses stumble - any color he happens to be, with a good flat-footed walk, a square trot and a free easy lope. He should be not more than eight nor less than four years old, and his back should be free from old saddle sores, bare scars, or "set fasts." Do jot let the seller assure you that such places are all healed up and will never be any trouble, for they will. A scar on a horse's back where the hair is gone will always be liable to break out into a sore place any time the conditions are just right.

I do not say that a horse without some of these points will not be a useful animal but these are the things which the young buyer wants to look for and the more he gets of them the better horse he will have.

In the age matter, no horse can be well broken to range work before he is four years old, and every year after he passes eight is just that much gone from his best age. So by getting between these one will secure the best there is in his horses. Look also to his tongue, lest at some time a heavy bit has cut it half in two, so he feeds with difficulty.

Gaits.-Some men will pay fancy prices for pacing horses because on a smooth road they will shuffle along at a good rate and carry their riders easier than at a trot. On a rough trail, however, or over a broken coun- 
rry they are constantly stumbling, owing to the way they carry their feet, that is, close to the ground. A man riding a pacer over a rough piece of road must be mighty even tempered or he will be everlastingly engaged in a "horse fight," until every time the poor animal stumbles it will break and run in expectation of being "worked over," as the cowboy says.

A man riding a pacer at the head of a line of mounted men can certainly deal them an immense amount of misery. The pace he sets is just a little too fast for them to keep up on a walk and not quite fast enough to let them trot, and thus they are continually alternating between the gaits. For range work a horse that will strike a good flat-footed walk and make about five miles an hour is worth a corral full of pacers.

A good rider can train his horse greatly to improve his walking gait by forcing him on a tight rein until he breaks into a trot. The instant he does this, pull him down to the walk again. By continually crowding him with the spurs and holding him carefully in hand just at the breaking-point, he will soon learn the fox trot trick and unless very tired will always take it of his own accord. A little patience along this line and one can make a gaited horse out of almost any horse.

In testing out a horse, see how he jumps out from a dead standstill, a slow walk and a trot into a lope. If he has been well trained for cow work he should, when struck sharply with the quirt or spurs, and feeling his rider lean slightly forward, jump into a good lope right from a walk. He should pull down from a dead run to a standstill in not more than twice his own length, stopping on his hind feet. With a very slight pressure on his neck from the bearing rein he should swing round 
on his heels like some racing yacht with the helm hard down and be off the other way with a dash the instant the reins are eased up, his side feels the touch of quirt or spur and the body of his rider bends forward over the horn.

When the reins are thrown over his head to the ground, he should stand there as if hitched. If he does not, wrap the reins about one of his front feet so as to hold his head down and keep him from stepping. This will educate him to stand. Sometimes a spoiled horse will hang his hearl to one side so that the reins drag free from his feet and thus travel off and leave his ricler in the lurch. It is hard to break a horse of this trick and the best way, when you can not tie him, is to slip the reins through one stirrup and from there to the horn. Tie them there just so that the weight of the stirrup keeps his head on one side and he can not travel but in a circle, and a horse wise enough to play the first trick will soon learn that he is helpless when thus fastened, and stand still. Also teach him to stand still as you go to mount until you are firmly in the saddle, and have given the signal to move off.

Learn to mount your horse like a cavalryman or cowboy. Do not, with one halnd on the horn and the other on the cantle, clamber up into the saddle as if you were getting into a farm wagon. Stand just in front of the horse's shoulder, facing the rear; take the reins, drawn up fairly tight, so as to steady the animal, and a lock of the horse's mane in your left hand. With the right hand take the stirrup and turn it to you far enough so you can put your toe into it. Then grasp the horn with your right hand and swing up into the saddle with a quick movement. If your horse is restless and not in- 
clined to stand, his forward lurch will set you into the saddle all the easier. By this method of mounting you are in command of the horse at all times, and do not have to let go with the right hand just at the critical

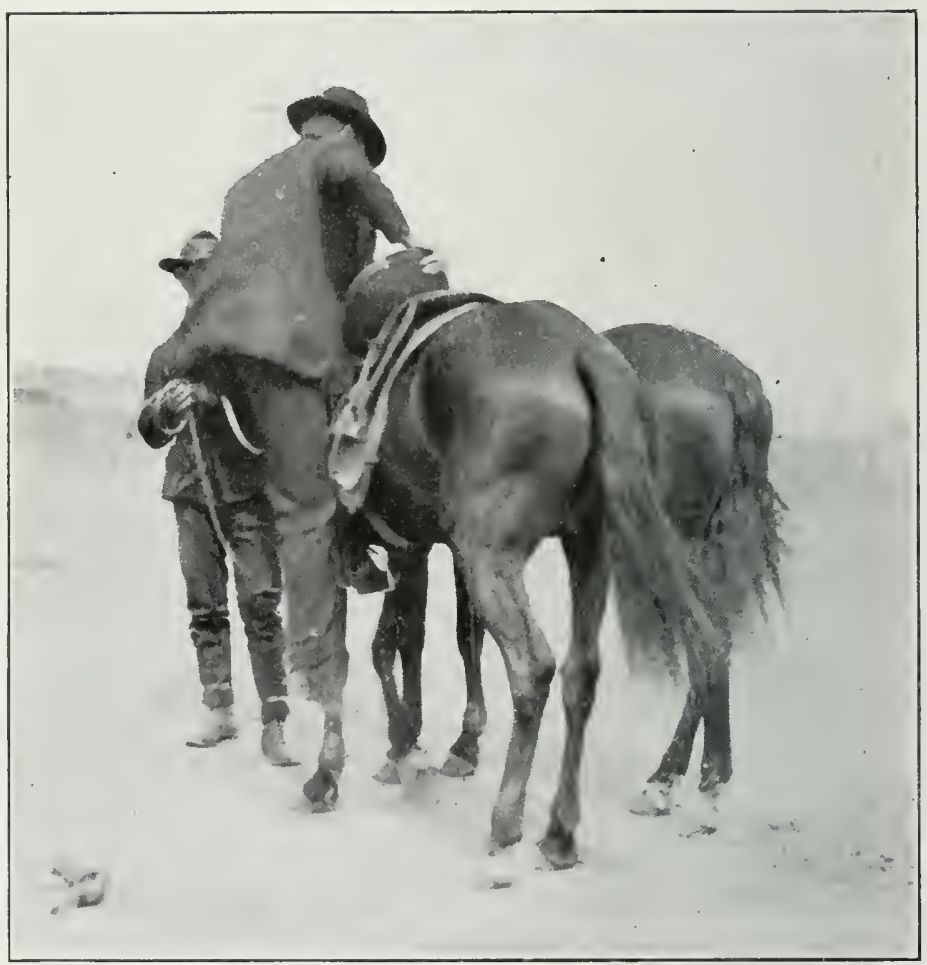

An Awkward Way to Mount.

time, as is the case when a man monnts with one hand on the horn and one on the cantle.

In dismounting as a preliminary learn to always draw your left foot back in the stirrup so as to leave only the toe in it. This will save you from being dragged some 
day when a nervous horse catches you with one foot on the ground and the other hung to the heel in a close stirrup. As a general rule ride with your feet clear in to the heels, but on a trot it will ease you greatly to slip your foot back, so that the ball of the foot rests on the

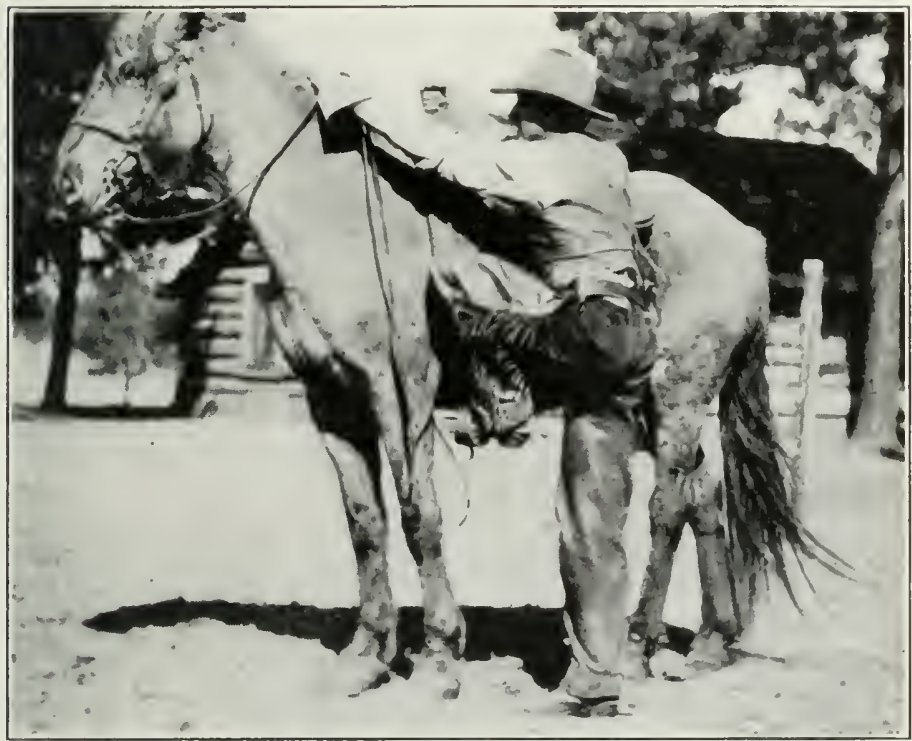

The Proper Way to Mount-"Ready to Swing Into the Saddle."

stirrup and takes up the jar with a sort of spring in the foot.

On a fast trot lean forward in your stirrups, standing clear of the saddle, and place a hand on the mount's mane, so as to steady and keep you on the balance. This eases the horse and rests the rider. Notice how the jockeys ride their racing mounts; they lean away forward, standing up in their stirrups. Ride from your 
knees and thighs; that is, hug the saddle with them, using the knee as if it were a ball and socket joint fastened tight to the saddle.

Learn to ride this way and you will never have any trouble with your trousers working up above the knees, as happens to most beginners.

If your knees and legs tire, turn slightly in the saddle, resting your body on the flat of the thigh, one foot remaining in the stirrup, the knee slightly bent, and let the tired foot hang free for a while. 'This takes the "kinks" out of the knees and ankles of a beginner and helps even an old rider.

The American Saddle Horse.-The true American saddle horse dates back to 1839 . In that year Denmark, a Thoroughbred stallion whose sire was an imported English Thoroughbred, was crossed with several wellbred Kentucky mares. This was the foundation of the American saddler, and the Denmark strain has come down through successive generations and is as jealously guarded by the Kentucky breeders as the Arabs guard the breeding of their horses. The Thoroughbred is simply a highly developed racing machine, with but one gait, while the saddle horse is a many-gaited animal. The average Kentucky saddler weighs about 1,050 pounds and is $15 \mathrm{1} / 2$ or $153 / 4$ hands high, bred, built, trained and used exclusively as a saddler. 


\section{HORSE EQUIPMENT FOR RANGE WORK.}

To the beginner the question of saddle, bridle, bit and spurs is a momentous one. Shall be buy a saddle with a horn or ricle a "muley"? Shall he have a "center-fire" or a "rimfire"? Shall it be a Texas or a California tree?

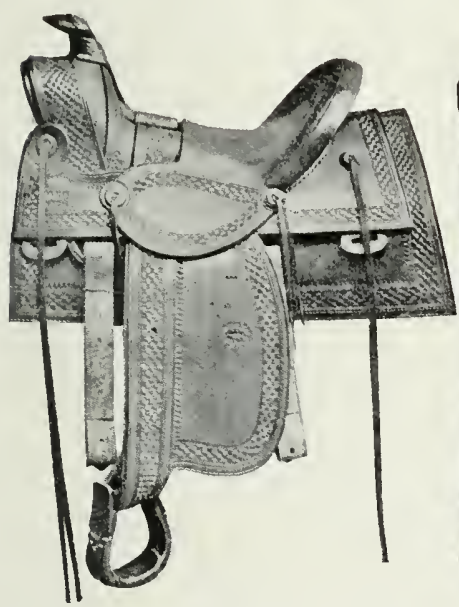

The Low Horn Texas Tree, Weight, 40 Pounds.

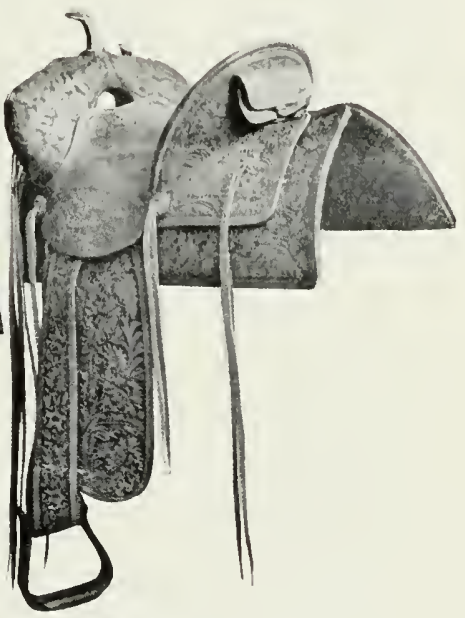

The Swelled Fork Tree.

Shall it have the huge eagle-billed "tapaderos" of the Pacific Coast or the simple narrow, iron stirrup of the Texan?

Saddles.-There are but two types of saddles to be considered: the McClellan or Government saddle, and the western stock saddle. The former weighs from nine 
to fourteen pounds; the latter thirty to fifty. Each has its merits, but for the use of a forest ranger, or for stock purposes the stock saddle is undoubtedly the better. The horn offers a handy place for hanging things, to say nothing of roping. while the skirting protects from contact with a sweaty horse any coat tied behind. Then the high cantle and pommel make the seat nuch easier especially in traveling over a rough country.

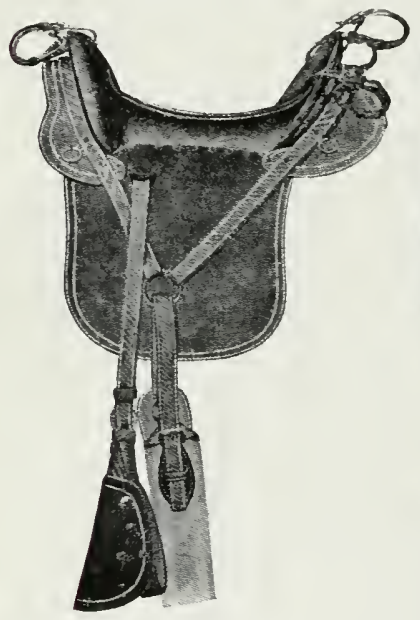

The McClellan or Government Type of Saddle.

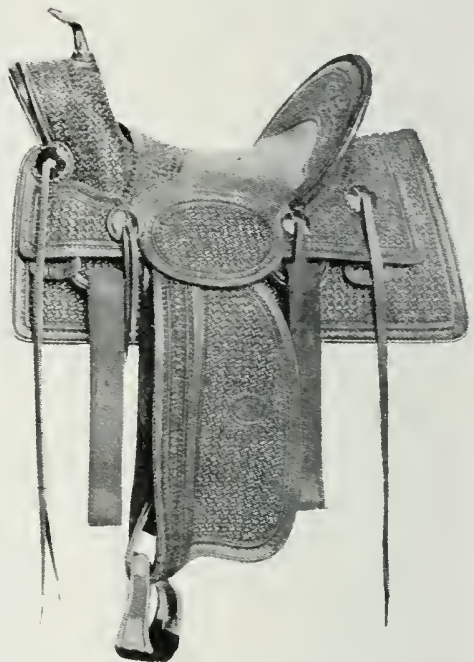

The High Horn California Visalia Type.

As for the rigging, the question of single cinch or "center fire," vs. double rig or "rim fire," is one that "starts something" every time it is discussed about a western campfire. The "double rig" is a Texas trademark, while the Californian is the defender of the single cinch. Both sides will quarrel over this matter for hours and neither convince the other. The Texan swears there are more sore-backed horses in one Cali- 
fornia county than in all Texas, and the Californian knows to a certainty that "every double rig saddle covers a kidney set fast as big as a biscuit." The truth is that there are plenty of single rig saddles that fairly "eat "1)" horses' backs, while on the other side there are as many double-rigged saddles doing the same thing. In my julgnent, apart from the (puestion of roping, both rigs are on the same footing in this matter.

In roping on a single cinch saldle the tendency when the rope is straight out in front or behind is to tip the tree up on end and dig it either into the animal's kidneys or withers. 'This does not occur with a double-rig saddle.

For use in a rough country there is certainly no comparison between the two styles. The double-rig saddle "stays put" all day long, even on a comparatively loose cinch, while the single-rig cinch must be pulled up until the animal is fairly cut in two, and yet at every hill the rider must stop to reset his saddle. The Californian will meet this by arguing that it is hard on the horse to keep the saddle in the same place, and hence to change it frequently relieves his back. But as between a singlecinch and a double-rig when it comes to general range work, just buy a double-rig saddle weighing not over thirty-two pounds and neither you nor your horse will regret it.

To my mind the low Texas tree known as the Friesseke is to be preferred to the California tree of the $\mathrm{V}$ isalia type, with its sky-scraping four-inch horn. Stop and think for a moment of the immense purchase it brings to bear in roping. In the higl arch Tisalia tree the rope with a 1,000-pound steer dancing at the end of it is probably seven or eight inches above the animal's 
withers. In the low Texas tree it is not over four, making a tremendous difference in the leverage against the animal in a side or even an end-pull. No wonder they have to stand in one stirrup to keep the single-rig highhorned tree from turning onto the horse's side when the strain comes on the rope.
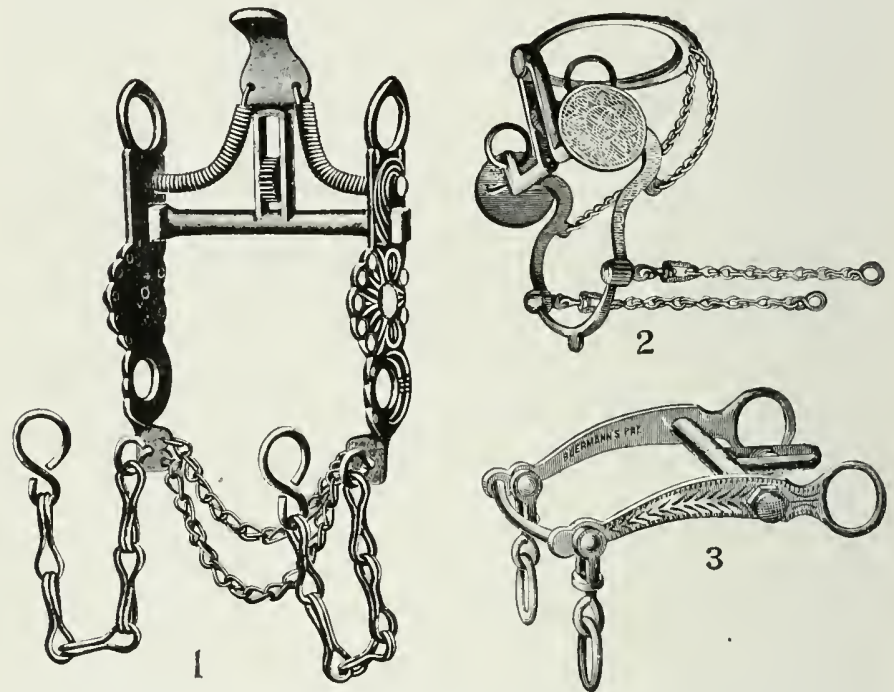

1. Spanish Spade Bit. 2. Spanish Ring Bit. (Both are brutal and of no practi. cal value in stopping a horse.) 3. A Modified Spanish Bit That is First Class For All Work.

Being California-bred, with five years' army experience in a Government saddle, and finally twenty years on a range where a man could not use a single-cinch saddle and hold his job. I feel competent to compare them all.

Bits and Bridles. - The California vaquero rode with a heavy silver-mounted spade bit with a lige burr or roller in it which made music when the horse rolled it with his tongue. These were and are an abomination. They 
were needlessly cruel and no more able to check a headstrong "bull-necked" horse than an ordinary cavalry bit. Moreover, if a horse fell with one, the great sharp spade sticking up in the roof of his mouth frequently cut him badly, and I have known at least two fine cow ponies to bleed to death from such accidents.

A good solid-made bit with a $U$ in it not over two inches at the best, with a burr or roller if one cares for it, and with shanks about five inches long, is good enough for any rider to use.

For reins there is plenty of choice. If you will once break yourself in to the use of then, "open" reins are the best; that is, the two reins are not tied together or fastened at the ends. The adrantage of this is that if you are rumning and your horse falls with you, the reins drop to the ground of their own accord and the animal stops; while tied reins frequently hang up over the animal's neck and away he goes. Again, in dismounting, in a hurry you simply drop your reins as you go down instead of stopping to strip them over his head. It is a little trouble at first to learn to handle open reins but once done you will never tie a knot in your reins again.

Blankets.-Have enough, and not too much. Too much is likely to scald a horse's back. Any loosely-woven wool blanket like the Navajo Indian blanket, folded so as to be about two inches thick, will do. The point is to keep the saddle blankets clean. One of the best ways is to wear a gunnysack between the animal and the blanket. A heavy coffeesack is the best but an ordinary burlap grainsack opened at the seams will do. This takes up the sweat and dirt from the horse and when dirty can be thrown away and a new one procured almost anywhere. 
A sore-backed horse is one of the worst things possible to use and heal up the sore at the same time. In this matter the ounce of prevention is worth the pound of cure every time. One of the easiest ways to insure a sound back is to throw a few cupfuls of cold water on his back when you strip the saddle off, loosening up the hair so that water and air will get through it. If you are near a stream or spring give the back a good washing, so that all the sweat and heat is taken out. This process also gives you early notice of an approaching sore spot.

In saddling, slip your left hand under the arch of the saddle between the horse and the blankets as you place it on the horse, and give the blankets a little lift so that they are clear from the withers; then when the saddle is cinched down, the blankets do not pinch the withers as the tree settles down over them.

Rope.-Always carry a grass or sisal rope about thirty feet long. You may not want to rope anything with it but a rope is always handy on the range, no matter what your business. The old days of the sixty-foot rawhide "riata" are pretty well gone. For ordinary use in roping, a three-eighths hard twisted Manilla or sisal rope will do the best work. If you are wise you will learn to rope with the rope tied "hard and fast to the nub" instead of trying to "take your dallies" or turns about the horn. This, like the question of saddles, is something over which much campfire talk is wasted. To the Californian it seems like inviting instant death to tie the rope. Per contra, the Texan cannot understand how a man can take the turns and keep his fingers clear from the entanglements of the rope.

Each is a matter of education. With your rope tied you are free from all bother in getting the turns at the 
right time. All you have to do is to manage your horse and keep the rope clear from his feet. Occasionally there will be a "mix up," your horse gets a leg over the rope and then something is doing in the vicinity. At the end of the deal, however, if the rope is strong you will come out of it with the animal still swinging to the end of the rope. In the same circumstances the Californian or "dally-welta" (Spanish-English for "dar la Vuelta," "give the turns") man will be minus a sixtyfoot riata which has "gone yonderly" with the steer. I have seen many more men hurt by taking their turns than by "tying 'em hard and fast."

To tie your rope about the horn so it will never pull up tight, and can be immediately cast off with the very least slack, take the knot end in your right hand, and the loose end in your left; pass the knot end around the horn, bring it back across the running or loose end on top, then back under and take one twist around itself, leaving the knot on the end under the rope between it and the horn. By drawing it up against the horn the knot will jam or bind between the rope and the horn so it cannot slip out, no matter how great the pull, and yet the instant the pull is eased off plenty of slack can be had to get the knot out and "turn her loose."

A tie made this way can never pull up tight enough that it will not easily slip off when the need occurs. Some men tie a regular loop in the end of their ropes, made just large enough to slip over the horn. This is dangerous, as it is apt to hang on something as you are using the rope on foot and catch a spur or your hand.

Spurs and Quirts.-Excepting in roping, one can get more out of a tired horse with a good cowboy quirt than with a pair of spurs. The quirt wakes him up, does not 
cut the skin and makes a more effective instrument for getting a quick move out of a horse. On a tired horse a man with a pair of spurs, especially the "pet-maker." kind, is very likely to keep "jabbing" all day long until at night he is surprised to find he has worn the hide and
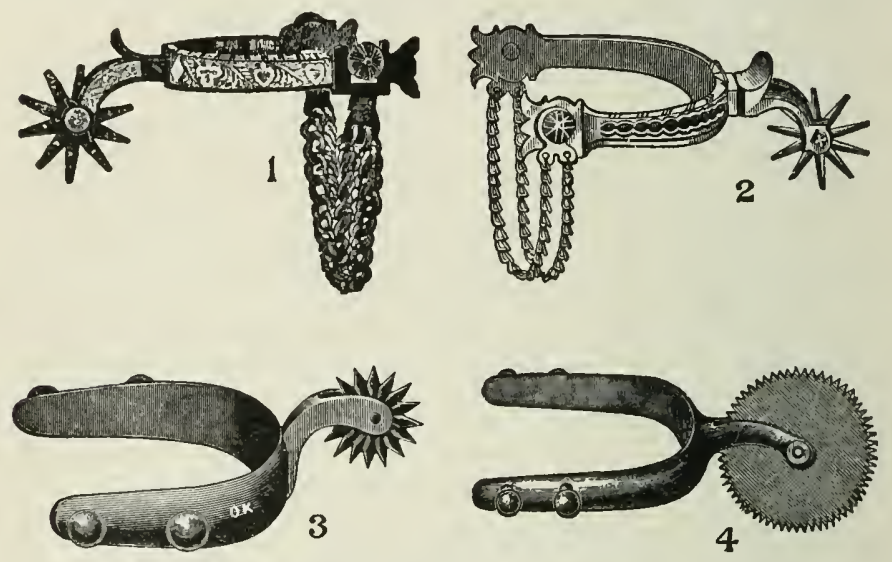

1. Spanish Spur, Silver Inlaid, 2. A Good Sensible Spur. 3. The O. K. or Petmaker Spur, 4. The "Buzz Saw."

hair off in each side where the spurs have dug. Some horses seem to get used to the constant touching up and finally ignore it altogether.

Hobbles (Hopples).-When knocking about on the range, depending on the grass for horse feed, don't carry along heavy leather hobbles. Instead, buy a piece of ordinary $1 / 2,5 / 8$ or $3 / 4$-inch sisal rope. Throw this in your pack, and at night when ready to "hobble out" unstrand it about five feet back. Most cowboys measure around their waists once and about two feet over, which is liberal for almost any horse. With unusually large or undersized horses, this measure may have to be changed a little, and this is easily done by the knot. 
Take a single strand, double it and tic the ends together in a conmon knot, just as a woman ties the knot in her thread. Stoop down, throw the knot end around the off front leg of your horse, bringing the knot

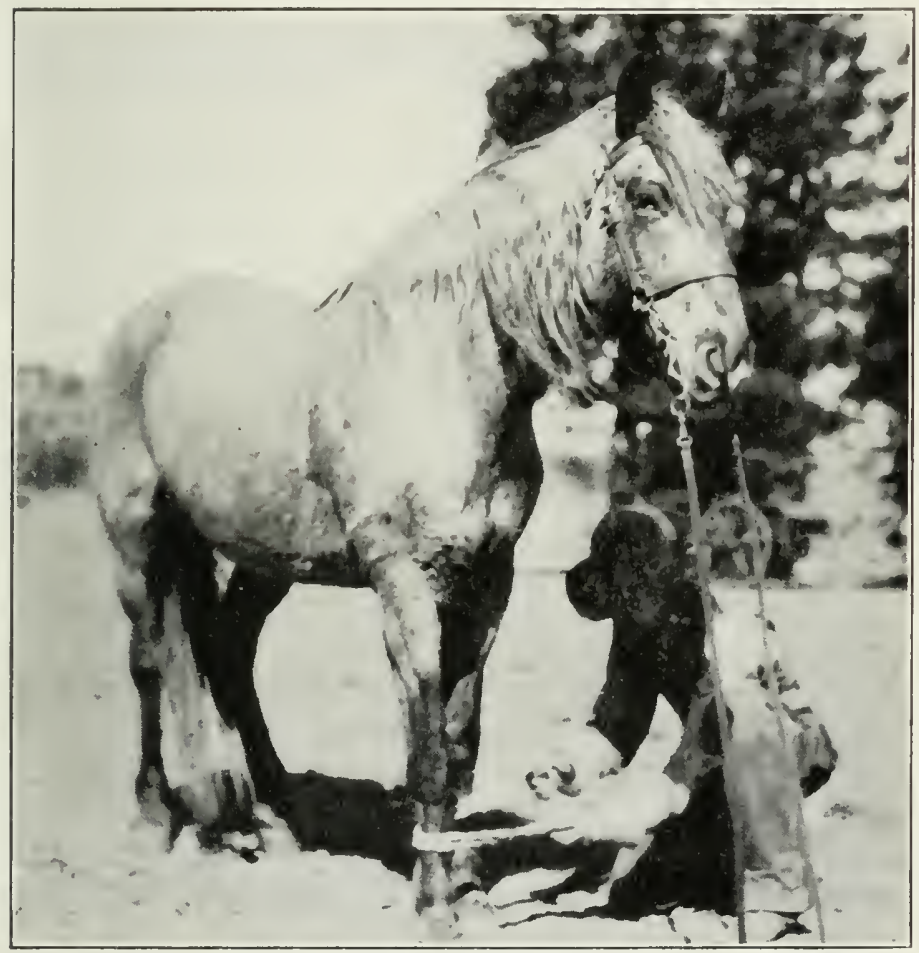

The First Step in Hobbling: "Around the Off Front Leg, Bringing the Ends Even in the Hands."

and loop end back even in your hands, and twist one about the other, generally four or five times. Leave enough to go snugly around the near leg, and fasten on the outside. 
To fasten, slip the knot end through the loop end from the inside out, then lay it over and alongside the lower strand of the loop, passing it up between the strand and the animal's leg. coming out between the two strands of the loop end. This will hold it effectually, and is easily unfastened the next morning when the rope is wet, frozen or covered with mud.

Tie each horse's hobble about his neck as you take it off, and he will carry it there all day, or, when you reach

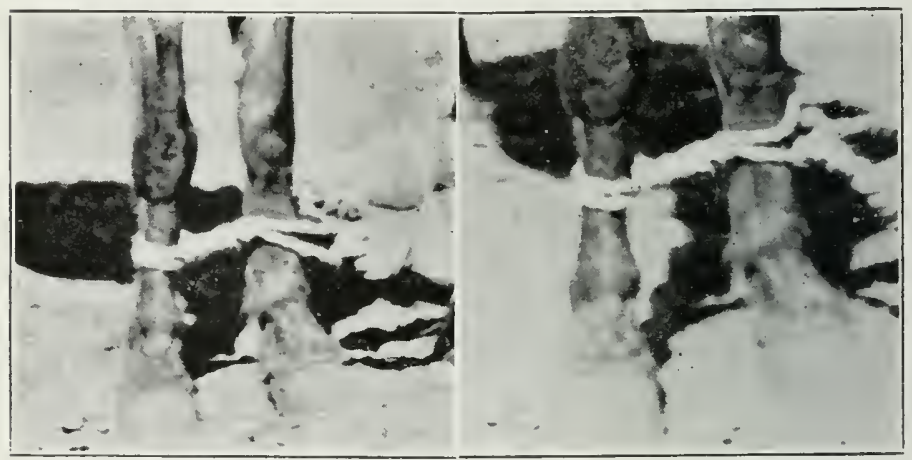

The Second Step in Hobbling: Twist One About the Other Four or

The Third Step in Hobbling. Five Times.

camp, it can be taken off and thrown into the pack or wagon. If the horse is not used to hobbles, and there is a tendency to skin his legs, place them above the fetlocks one night and below the next. If he is mean to run off with the hobbles "side line" him also by the same method, that is, a front and hind foot together, and he cannot go far.

If there is anything handier about a pack outfit than these hobbles for lengthening a lash rope, tying on a forgotten coffeepot or a thousand and one unexpected 
things where a bit of rope is needed, I do not know what it is.

Pack Saddles.-Two general types of pack saddles are used in the West; the aparejo and the sawbuck. The aparejo (ap-ah-ray-ho) is used exclusively in Government pack trains or where the work is done by experienced men who are constantly packing and will keep the

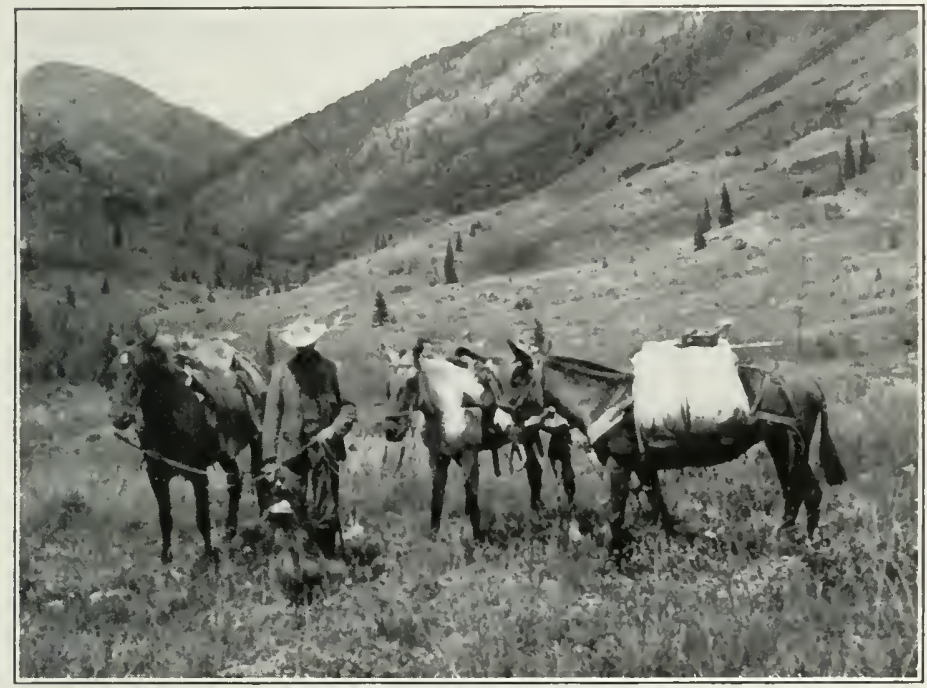

A First-Class Job of Packing.

rigging in order and well set up. For use with large trains handled by experienced men, the aparejo is by far the most humane and satisfactory method known for carrying all kinds of materials on a mule's back; but for occasional trips in the hands of the ordinary western man, the sawbuck patteru is the one in general use.

There are some modifications of it. The most successful is where the cross trees are carried down on the 
animal's side some distance, with the idea of keeping the pack off its ribs. The "cross trees" are simply the cross pieces which are bolted to the "bars" or flat parts which bear on the animal's back. In the improved form they come down below the bars about eighteen inches but do not touch the blankets at all, being curved to follow the lines of the barrel or ribs and hang clear of the animal. The effect is much the same as that gained by the use of the Basquo hitch, mentioned under the head of "hitches."

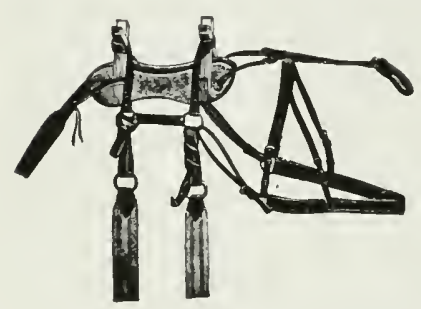

Double-Rigged Pack Saddle.

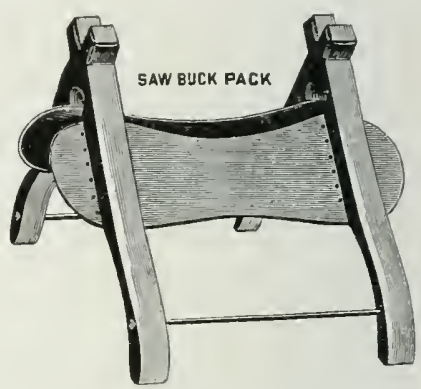

The Shape of the Tree Keeps Load Off a Horse's Ribs.

The cross tree or sawbuck saddle in the hands of a careless man is undoubtedly about the most satisfactory and ingenious method of torturing a poor animal that has ever been invented. I have seen pack trains in the Sierras and in Nevada packing cordwood down a steep mountain trail day after day, each mule with a sixth of a cord of heavy pitch pine on its back, with the sawbuck saddle used by careful humane packers, without a mule in the train showing a sore back. I have also seen similar trains where one could not walk on the lee side of the mules in the corral, so offensive was the odor from sore backs. I have also seen a tenderfoot packer 
load threc blankets and ten pounds of grub on such a saddle and tear a horse's back all to pieces inside of three days. It is all in the packer.

See to it that the saddle sets just where it should; not too far forward where it will dig into the withers, nor too far back so as to eat up the kidneys. See that

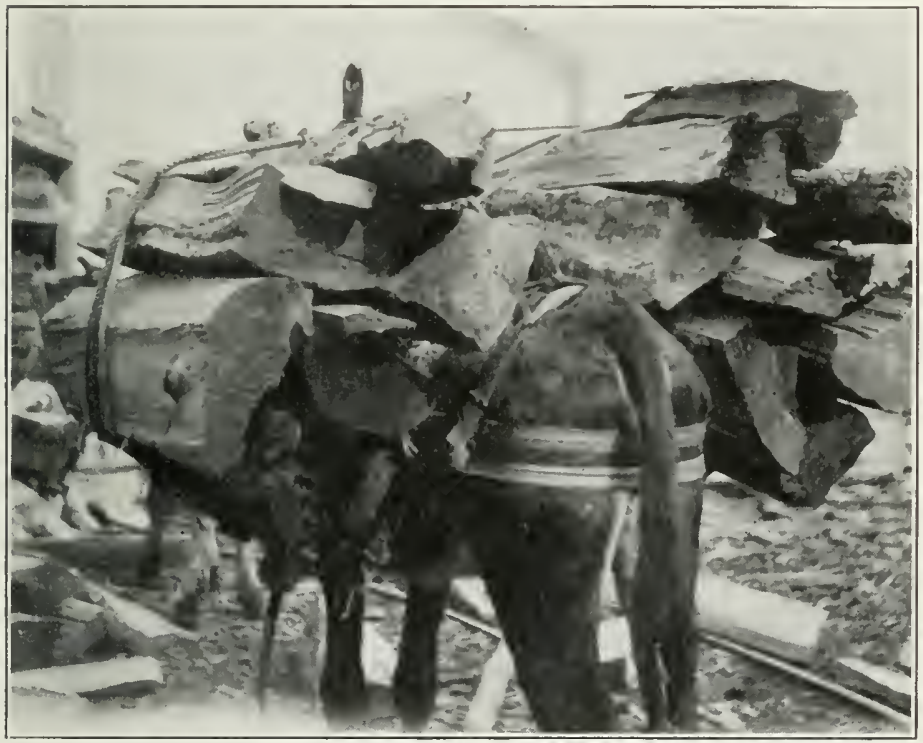

Packing Wood Down a Nountain Side; Six Loads to the Cord.

the breeching and breast straps are fastened so as to keep the saddle in place and still not choke the animal going up hill or wear the hide all off his hindquarters going down.

Have it double-rigged, no matter what may be your private opinion of that rig for a riding saddle. See that a fork or knife does not work through the kyaks and 
dig into the horse's back or ribs all the day long. Do not be so lazy that when you stop at noon you allow the animal to wear the pack for an hour or so instead of taking it off and giving him a rest too. If you can do it, make your journey all in one march and get it over with and the pack off for the day. Keep the ropes tightened up. After going a mile or two in the morning, make it a plan to stop the outfit and go over the packs and see how everything is riding. With this overhauling the average pack should ride all the rest of the day.

For regular traveling in the mountainous country 200 pounds is all an animal should ordinarily carry. Its pack is a dead load and carries heavier than the load your saddle animal carries.

Hitches.-There is a good deal of glamour about the "throwing of the diamond hitch." To many people it is believed to be a sort of patent of frontier nobility. This may be so to a certain extent, but there are many old-time westerners who never knew how to throw the diamond and still have spent many years of their lives in handling pack outfits. The truth is that the diamond hitch is rather a professional tie to be used with an aparejo. It can be and of course is used with other packs and outfits, but to learn it is not an easy matter and unless one is using it all the time and in constant practice one is apt to get mixed on it and end up with what is frequently called an "Oregon wind." (Make that word rhyme with "find.") There are an endless number of hitches used by western men, as the squaw, the stirrup, the bed and the basco; all are good and for their purposes quite as satisfactory in every way as the diamond. Of these there are but two to which I shall call at- 
tention. One is to be used in packing simply a bed from camp to camp. Lay the bed canvas on the ground and place the blankets in the center of it at full length but folded once, so as to make the pack about $31 / 2$ feet wide and the length of the blankets. Fold the canvas over the blankets and then lay the pack across the animal's back, allowing it to hang down on each side. Pass each end around the body of the pack animal so as to

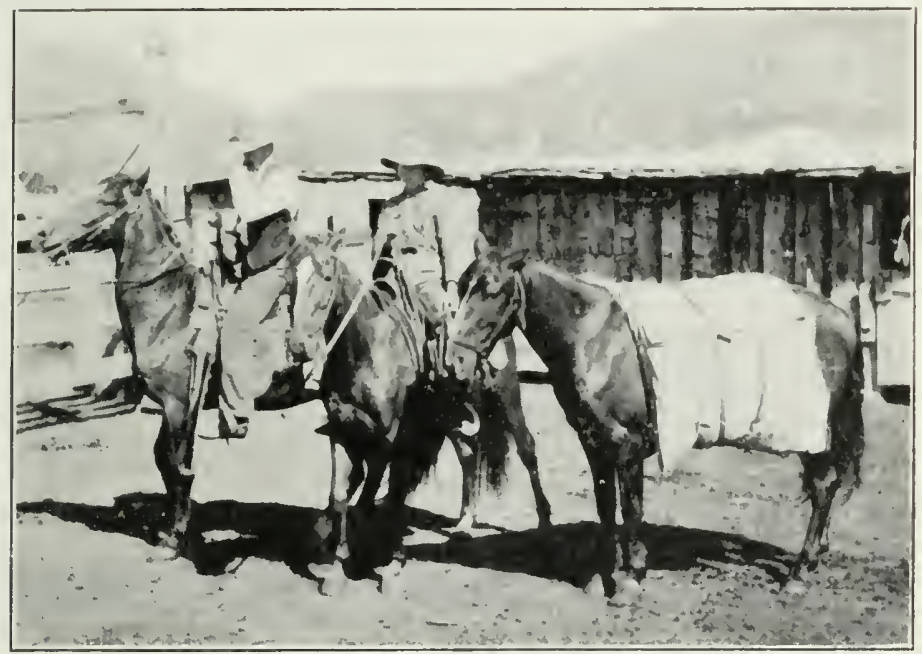

A Handy Bed Pack Sometimes Called "The Oregon Wind,"

form a belt about him. Then open the loop of your rope large enough to allow the horse to step into it and bring it back around the blankets about six inches from the front edge. Slip the hondo or loop up until when pulled tight it will come right back of the withers and just over the backbone. Draw it as tight as possible, then carry the loose end back about a foot, carry it around the animal, bring the end through the rope so as 
to make a hitch about the pack and draw it as tight as possible. Repeat this again another foot back and make the end fast.

This pack will ride all day long but like any other pack it will need tightening following the natural loosening up of the rope, due to the settling of the load. The beauty of it is that it can turn over and do no harm. Going up a steep mountain trail, if it is not pretty tight it is likely to be shed over the animal's tail, in which event you will have a stampede and some scattered bedding to pick up. With a mixed pack, however, a lot of bedding, cooking utensils and grub, one must either have them done up into bundles, tied in sacks or packed in "kyaks" or pack pockets. In California they call them alforjas (al-fork-has). These are either heary canvas or leather bags or made by taking ordinary ten gallon coaloil cases or other wooden boxes about the same size, and stretching over them a fresh rawhide. The hide of a yearling steer is the best for this purpose.

With a pair of leather or rope ears these are swung over the pack saddle, filled with the easily broken or "losable stuff" and the blankets spread over them. On top of this place the canvas and you have a mighty good pack to carry almost anything that a man wants to pack in the mountains.

Now for the Hitch.-Of all the many western hitches for pack purposes the one used in California by the Forest rangers in the Sierras is to my mind the most easily learned, the easiest to remember after being out of practice for a year or so and the easiest for one man to handle alone.

With two men, the man on the "off" side takes the 


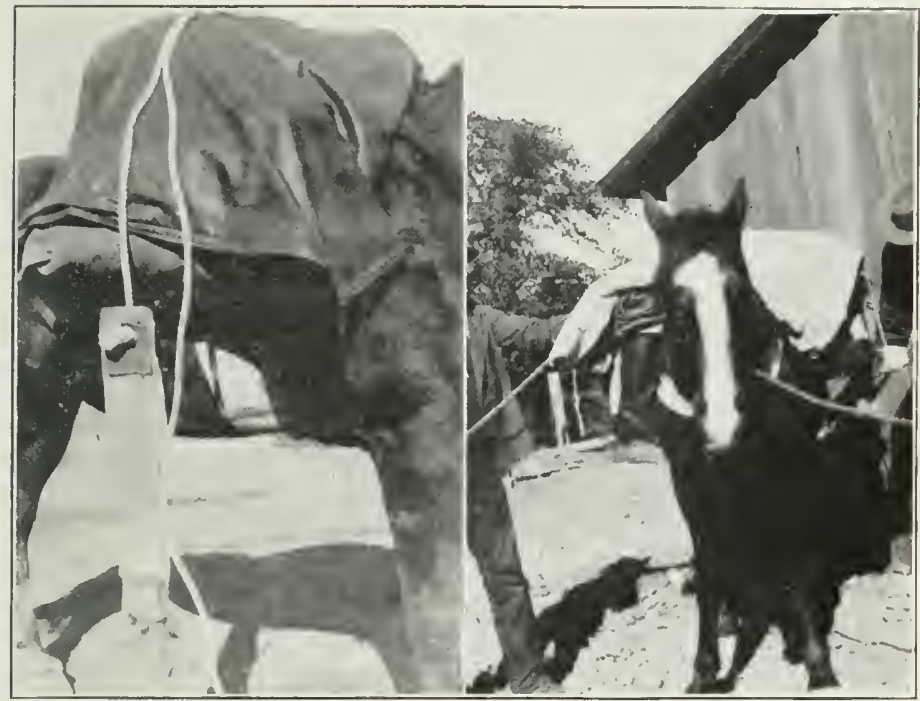

Fig, 1. - The "Off" Man Throws Over Fig. 2.-The "Near" Man Pulls on the Top of the Pack a Loop of the Rope. the Running Part of the Rope.

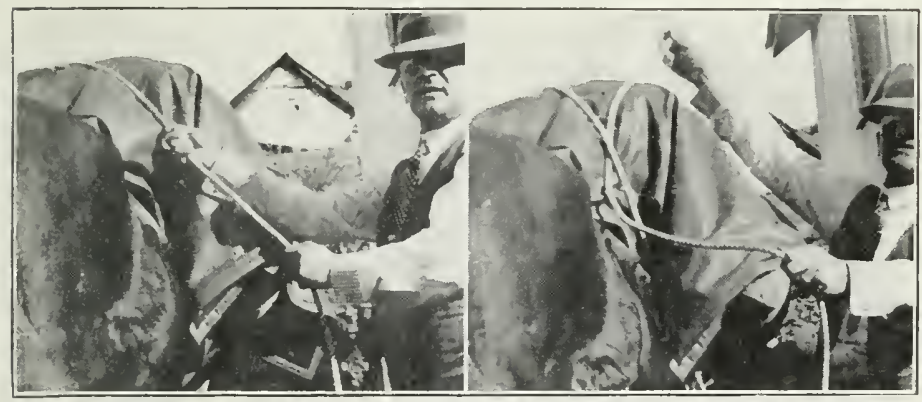

Fig. 3.-The "Off" Man Passes It to Fig. 4.-With His Left Hand Slips a the Left and Rear of the Pack. Loop Under From the Rear. 


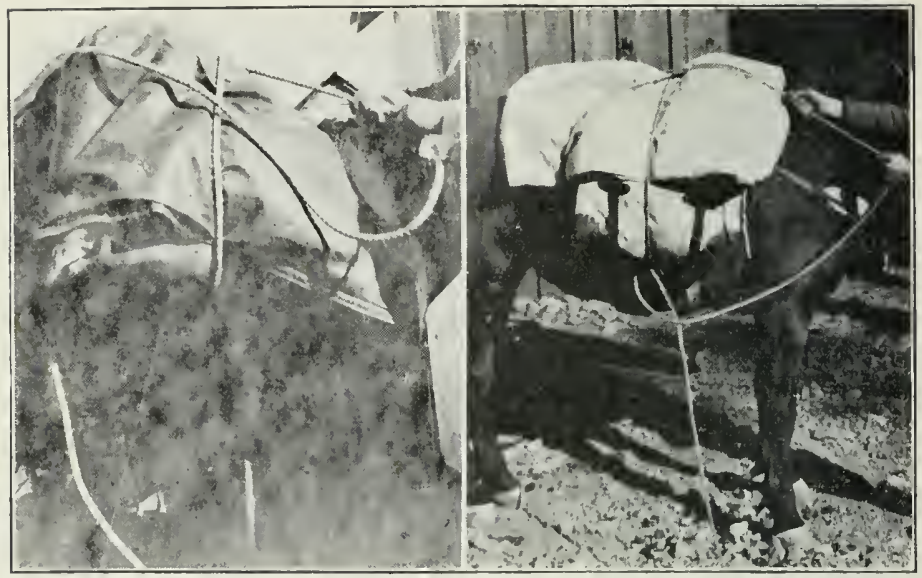

Fig, 5,-Draw Out More of the Run. Fig. 6.-Work the Running End Down ning End, Making a Large Loop. along the Main Rope Around the Rear Corner and Forward Until It Is In the Center of the Pack.

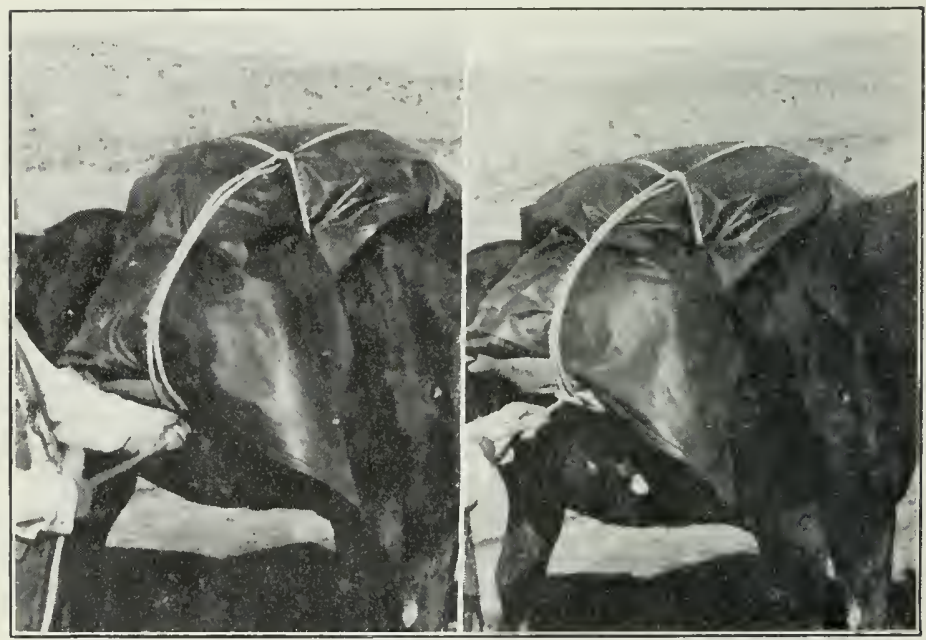

Fig. 7.-Pulling Down So It Rests Fig. 8,- "Give a Good Pull on the Against the Pack. Running End, Pulling Up." 
lash rope and cinch, keeping the coil of the rope on his side. He throws over the top of the pack a bight or loop of the r.pe (Fig. 1), which the "near" man takes, places the loop in the cinch hook which the "off" man pushes to him under the animal's belly, and slips the hook far enough under the animal so that when tight it will pull up just below the lower edge of the pack. The "near" man then shouts "take," and pulls on the running part of the rope until the cinch is tight enough (Fig. 2.) The "off" man takes the slack as it comes, passes the rope to his left and the rear of the pack (Fig. 3) ciear down under the corners and well back, then across to the right well under the pack, around and under the front corner, and up again to the center and top of the pack.

He holds this from slipping back by his right hand. while with his left he slips a loop of the rope under the rope that came over to him from the "near" side, pushing it under that rope from the rear as shown in Fig. 4. This all takes place on top of the pack.

Take the right hand side of this loop in the right hand, and hold it from slipping back, while with the left hand draw out more of the rumning end, making a much larger loop (Fig. 5). Then work the lower end of this large loop down along the main rope under the rear corner of the pack, around towards the front until it is in the center of the pack about where the cinch ring comes, but still under the main rope (Fig. 6). Then tighten the rope by pulling on the part in your right hand (Fig. 6). Pull it forward in line with the animal's backbone, never out to one side. This is an invariable rule in good packing; pull in line with the animal, never sideways.

This should bring the "twist" of the lash rope about in the center and somewhat on the side of the pack; 
then while holding it from slipping with the right hand take up the slack in the running end with the left hand, pulling down so it rests closely against the pack (Fig. 7). When this is done, give a good pull on the running end, pulling up on it (Fig. 8). This draws the rope tight and, if the job has been well done, the lower edge of the pack will be drawn up and away from the animal's body, swinging clear-a most satisfactory way for a pack to ride. Then throw the running end of the lash rope over to the man on the "near" side who repeats the process on his side and finally makes the end
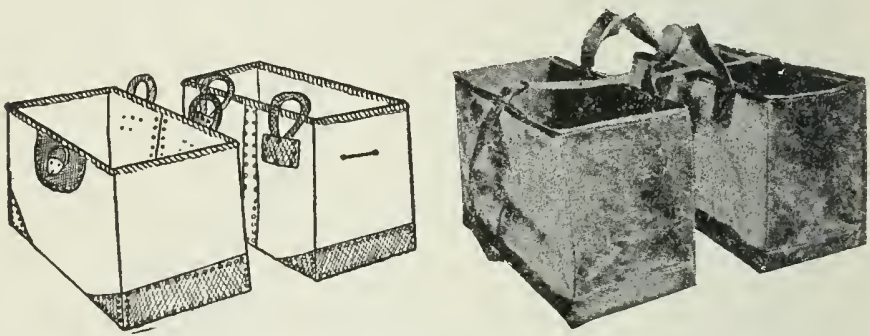

Kyaks (Alforjas in Spanish) or Pack Pockets. The Loops Hook Over the Tops of the Pack Saddle, A Light Wooden Box in One Is a Great Advantage.

of the lash rope fast on the top and the job is done. At this point if packing alone, slip a little loop of the loose end you have thrown over, under the tight rope on top, so it cannot run back and loosen up. Then when you get on the other side a quick jerk will pull it from under the tight rope and you can go ahead on that side.

Such a pack rides well, is readily tightened, can be handled nicely by one man, is quickly cast off to unpack, takes any 35 feet of lash rope, is readily learned and not easily forgotten. There is nothing so disagreeable in packing as a wet lash rope, hence it should be kept dry 
in camp and if possible when wet at unpacking should be dried out before the campfire at night.

When laying out your packs care must be used to have the two sides as nearly equal in weight as possible. If you use kyaks take along plenty of gunny-sacks with which to wrap things and keep them from rattling. Of all disorderly affairs a kyak full of cooking and eating utensils all rattling and jingling like a tin pedder's wagon is the worst. Besides it is apt to wear holes in the kyaks and break some of the contents. I have seen both Gen. George Cook and Gen. Mackenzic, two of the old-time Indian fighters of the army, stop a pack train passing in review before them, as it left camp for the field on an Indian scout, and make the packers pull a certain mule out of the train, unload a noisy pack and remedy the trouble right there before them, with possibly 250 cavalry men and the packers of a 100-mule pack train "guying" the unlucky packer as they rode past. 



\section{APPENDIX.}

\section{A BILL.}

For the improvement of grazing on the public lands of the United

States, and to regulate the same, and for other purposes.

Be it cnacted by the Senate and House of Representatives of the United States of America in Congress assembled, That the unreserved, unappropriated public lands of the United states shall be subject to the provisions of this Act, and the President of the United States is hereby authorized to establish from time to time, by proclamation, grazing districts upon the unreserved, unappropriated public lands of the United States, conforming to State and County lines so far as practicable, whereupon the Secretary of Agriculture, under rules and regulations prescribed by him, shall execute or cause to be executed the provisions of this Act, appoint all officers necessary for the atministration and protection of such grazing districts, regulate their use for grazing purposes, protect them from depredation, from injury to the natural forage crop, and from erosion; restore and improve their grazing value through regulation, by the eradication of poisonous plants, and by the extermination of predatory animals and otherwise: eradicate and prevent infectious and contagious diseases injurious to domestic animals; issue permits to graze live stock thereon for periods of not more than ten years, which shall include the right to fence the same, giving preference when practicable to homesteaders and to present occupants of the range who own improved ranches or who have provided water for live stock grazed on the public lands; and charge and collect reasonable fees for such grazing permits, based upon the grazing value of the land in each locality: Provided, That for ten years after the passage of this Act such charge for grazing shall not exceed four cents per acre nor be less than one-half cent per acre, or the equivalent thereof on a per capita basis, and the Secretary of Agriculture shall revise and re-establish maximum and minimum rates of charge for grazing for each succeeding period of ten years.

SEC. 2. That homestead or other settlement, location, entry, patent, and all other disposal of public lands under the public-land laws shall be in no wise restricted, limited, or abridged hereby; nor shall anything herein be construed to prevent bona fide settlers or residents from grazing their stock used for domestic purposes, as defined under the regulations of the Secretary of Agriculture, on the public lands affected hereby: Provided, That after the establishment of any such grazing district no form of location, settlement, or entry thereon shall give a right to grazing privileges on public lands except when 
made under laws requiring cultivation or agricultural use of the land: Provided further, That permits to graze live stock upon land which is subsequently appropriated under any public-land law shall not be affected by such subsequent appropriation, except as to the land actually appropriated, until the end of the current annual grazing period: Provided further, That no permit shall be issued which will entitle the permittee to the use of any bulldings, corrals, reservoirs, or other improvements owned or controlled by a prior occupant until he has paid such prior occupant a reasonable pro rata value for the use of such improvements. If the parties interested can not agree, then the amount of such payment shall be determined under rules of the secretary of Agriculture: And provided further, That when buildings, corrals, reservoirs, wells, or other improvements, except fences, shall have been established on any forty-acre tract to the value of more than one hundred dollars, as determined by rules of the Secretary of Agriculture, such forty-acre tract shall not be subject to settlement or appropriation under the public-land laws during the permit perlod without the consent of the owner of such buildings, corrals, reservoirs, wells, ol other improvements.

SEC. 3. That all water on public lands or subject to the jurisdiction of the United States within such grazing districts may be used for milling, mining, domestic, or irrigation purposes under the laws of the State or Territory wherein such grazing districts are situated, or under the laws of the United States and the rules and regulations thereunder.

SEC. 4. That no grazing permits issued under this Act shall prohibit settlers, prospectors, and others from entering upon such grazing districts for all proper and lawful purposes, including the use and enjoyment of their rights and property and prospecting, locating, and developing the mineral resources of such districts; and wagon roads or improvements may be constructed thereon in accordance with law, and all persons shall have the right to move live stock from one locality to another within such grazing districts under such restrictions only as are necessary to protect the users of the land which will be driven across.

SEC. 5. That the users of the public lands under the provisions of this Act may select a committee of not more than four members from the users of any such grazing district, which committee shall represent the owners of different kinds of stock, and, with the officer appointed by the Secretary of Agriculture in charge of such grazing district, shall constitute an executive board, which shall determine whether the permits for such grazing districts shall be issued upon an acreage or upon a per capita basis, shall make such division of the range between the different kinds of stock as is necessary, and shall decide whether the distribution of the range shall be by individual or community allotments. The executive board shall also determine the total number of animals to be grazed in each grazing district, and shall decide upon the adoption of any special rules to meet local conditions, and shall establish lanes or driveways, and shall preseribe special rules to govern the movement of live stock across the public 
lands in such districts so as to protect the users of the land in their rights and the right of persons having the necessity to drive across the same. The executive board, after thirty days' notice by publication, shall also determine the preference in the allotment of grazing privileges provided for in section one of this Act, and shall, under rules of the Secretary of Agriculture, determine the value of the improvements and the use of the same whenever that may become necessary under the provisions of this Act in the administration of the same. Fences, wells, and other improvements may be constructed with the permission of the Government officer in charge, who shall record the ownership and location of such improvements. Any differences between a majority of the executive board and the officer in charge shall be referred to the Secretary of Agriculture and shall be adjusted in the manner prescribed by him. Any interested party shall have the right to appeal from any decision of the board to the Secretary of Agriculture. If the users of the land fail to select the committee as herein provided, the President of the United States shall name such committee from such grazing districts, representing the owners of the different kinds of stock, as above provided.

SEC. 6. That the Secretary of Agriculture shall fix a date which shall not be less than one year from the establishment of any grazing district, and after such date the pasturing of any class of live stock on public land in said grazing districts without a pernit, or in violation of the regulations of the Sccretary of Agriculture, as herein provided, shall constitute a misdemeanor and shall be punishable by a fine of not less than ten dollars nor more than one thousand dollars, or by imprisonment for not less than ten days nor more than one year, or by both such fine and imprisonment, in the discretion of the court.

SEC. 7. That twenty-five per centum of all moneys received from each grazing district during any fiscal year shall be paid, at the end thereof, by the Secretary of the Treasury to the State or Territory in which said district is situated, to be expended as the State or Territorial legislature may prescribe for the benefit of the pubiic schools and public roads of the county or counties in which the grazing district is situated: Provided, That when any grazing district Is in more than one State or Territory, or County, the distributive share to each from the proceeds of said district shall be proportional to its area therein The sum of five hundred thousand dollars is hereby appropriated, to be available until expended, for the payment of expenses necessary to execute the provisions of this Act.

SEC. 8. That the President is hereby authorized to modify any proclamation establishing any grazing district, but not oftener than once in five years, to take effect in not less than one year thereafter, and by such modification may reduce the area or change the boundary lines of such grazing district. 


\section{A FEW DEFINITIONS.}

Following is a list of definitions of words and expressions in common use among stockmen:

Arroyo.-(Spanish). Small dry wash, small river. Used in the Southwest generally to designate a dry wash.

Ialdy, Bald-Faced.-Horse with a white face.

Bed Ground.-The place where a herd is held for the night.

Hig Jaws.-Animals showing signs of the disease known as lump jaw or big jaw (actinomycosis). Dogies, dwarfs, swaybacks and big jaws are generally mentioned in all steer-buying contracts as not to be received by the purchaser and not to be considered as part of the percentage of cut allowed the buyer.

Bog Rlders.-Men whose duties are to ride the ranges in the spring and look out for weak cows that get into mud holes and have not sufficient strength to get out again.

Broken-Mouthed.-Applied to a e:we or sheep which after reaching the age of seren generally loses some of the front teeth: an old sheep.

Bronco.-Wild horse; any unbroken horse.

Bronco Buster, Bronco Twister.-A man hired to break bronco horses.

Euckaroo.-Southern California corruption of Spanish word "vaquero," cowboy.

Bucklng Up.-Placing the bucks with the ewes. A band of sheep is sold "bucked up" to lamb on certain dates.

Caballado.-(Cah-val-ya-do). The horse herd.

Camp Tender, Camp Rustler.-A man who accompanies the sheep herd, looks after the packs, locates camp and relieves the herder from such matters.

Cantlnas.-A pair of saddle bags that hang over the saddle horn.

Caporal.-(Cap-o-ral.) The foreman in charge of a sheep outfit. Cavvard, Carvy.-(Spanish). A bunch of horses.

Chamlsal.-(Cha-me-sal.) Applied by Mexican sheep-herders to a range where the majority of the feed is browse and weeds.

Chaparnjoes, Chaps.-(Shaps.) Leather covers for the legs when riding in brush. From Spanish chaparral, thlek brush. Properly pronounced chap-ar-rer-as.

Chupo, Chapo.-(Spanish.) A short-coupled chunky-bullt horse.

Cienaga.- (Se-en-ega.) From the Spanish cien, meaning hundred, and agua, meaning water. A wet, swampy place with many springs.

Coones.-A raw hide slung under the rear axle and reach of the chuck wagon in which the cook carries his iron dutch-ovens and other heavy utensils. Often the brands are carried in it also. 
Coulee-(French). Used in the Northwest much the same as Arroyo in the Southwest.

Counting Chute.-A V-shaped fence into which the shcep are crowded and as they escape through a small openlng at the point can be readily counted.

Crop.-To cut off the end of the ear.

Cross-bred.-A product of Merino and mutton blood. A type of sheep producing a fair grade of medium wool, together with a large carcass for mutton purposes.

Culls or Cutbncks.-Those animals in a herd which for his own reasons a buyer rejects.

Cut.-In sheep-herding, a small number of anlmals that get separated from the main herd; in cattle, a bunch of cows or steers that are cut out from the herd to be driven off.

Cutter.-Slang for six-shooter.

Cutting Ilorse.-A horse used especially for the work of cutting out; a "carver," a "chopper," chopping horse.

Cutting Out, Prating Out, Carving, Chopplng.-All cowboy expressions to cover the operation of removing from the herd such animals as are needed, like cows, calves and steers. Cutting "double barreled" is done by two men; usually but one man works.

Day Iferd.-The animals carried along with the roundup outnt into which those animals that are wanted for shipping or other purposes are placed.

Dilkey. - A saddle mare.

Docking.-Cutting off the tails of lambs. Done primarily for sanitary reasons but also for breeding reasons in the casc of the ewe. In the wethers it is more or less a fancy that it makes a better looking animal, trimmer and more symmetrlcal.

Doctoring Sheep.-To go over a sheep herd and "doctor" by hand such as show signs of scab.

Dodge Grte.-A gate in a corral generally in a lane down which animals are driven and "dodged" or separated as they come, by swinging the gate back and forth so as to classify them.

Dogle.-(Dough-gle). A motherless calf on the range. Generally applied to those calves whose mothers have died or been separated from them. A pot-bellied calf.

Double Rig Saddle.-A saddle with two cinches; a "rim fire" saddle.

Downers.-Cattle and other stock which have been down in the cars during shipment and arrive at the stockyards bruised, dirty and unfit for sale as beef.

Drop Band.-Ewes that are just ready to drop or are dropping their lambs.

Dry Stufi.-Cows or ewes without young.

Dwarfs.-Undersized anlmals; those which have been stunted in some way; runts.

Flly.-A female horse under two and one-half years.

Fine-wooled, Close-wooled.-Applied to the Merino breed, whlch includes Delaines and Rambouillets.

Freemartin.-Generally applied to the female born twin with a bull. Commonly supposed to be sterile but many instances are known where this is not the case.

Gelding.-A castrated horse.

Grafting Lambs.-The operation of coaxing a ewe to mother a strange lamb. 
Gotcho.-(Mexican.) A droop-eared or lop-eared horse.

Grub.-To cut the ear off close to the head for an ear-mark.

Grullo (Grew-yo).-(Spanish or Mexican.) A dull slate or smoke-colored horse; a "smoky."

Hackamore.-(Jaquima). A headstall used in breaking saddle horses. A Spanish word taken from the Arabian.

Helfer.-A female of the bovine species before she has aropped her first calf. After that she becomes a cow.

Hinny.-The offspring of a stallion and a jenny or female ass.

Hogglng Rope.-Short piece of rope for use in hog-tylng an animal.

Hog Tle.-To tie an animal down by all four feet.

Hoodium Wagon.-The extra wagon taken with the chuck wagon on the roundup to haul grain, extra bedding, and at times wood and water.

Hospital Hunch.-On a sheep range those animals that are slck. injured in some way, or ewes with lambs which are not thrifty and therefore need more care than they get in the large herd.

Jack.-A male of the ass species.

Jennet.-(Genet.) A small Spànish horse in range language.

Jenny.-A female of the ass species.

Jingle Bob.-An ear-mark made by cutting the ear on the upper side, so as to break the back of the ear. This allows it to hang down along the side of the face much as do the long ears of the Angora goat.

Jug Handle.-A mark made in cattle by slitting the dew lap about 4 inches so that the outside strip hangs free from the animal.

Lasso.-(Spanish.) To snare; to rope; rope used by stockmen to catch cattle.

legging out.-The act of pulling sheep out of a bunch by the hind legs, catching them either with the hand or the crook.

Lepple.-A southwestern name for dogie. Taken from the Spanish.

Loafer.-Western corruption of the Spanish Lobo; a wolf.

Mare.-A female of the horse species over two and one half years of age.

Markers.-The black sheep in a herd. Every herder knows exactly how many of such he has and by running over them occasionally he feels fairly sure that if they are all there he has lost no sheep.

yarerick.-An unbranded calf or colt not following the mother. The name goes back to early days in Texas when a man named Maverick ran cattle on a small island, and hence neither branded nor marked them. Occasionally one or two would swim to the mainland and when found in the herds were known as maverick cattle, and soon the name was adopted for all such animals.

Mecate-(Me-cah-tee). A hair rope used as a tie rope for horses: often called "Macarty," used with hackamore rig. In Mexico, a maguey rope.

Mlllng.-A herd of stock held under guard where the anlmals keep walking round and round in one direction.

Morphodlte, Hermaphrodite-An animal having the generative parts of both sexes. This name goes back to the old Greek story of the son of Hermes and Aphrodite, who, while bathing one day, became united in one body with a water nymph. 
Mule.-The offspring of a mare and a jackass.

Mulley.-A hornless animal; a saddle with no horn.

Nester.-A small farmer generally located within the limits of some stock range.

open-wooled, Coarse-wooled.-Applied to sheep of the mutton breeds, such as Lincolns and Shropshires.

Orejann.-(Oh-ray-hah-na). From Oreja, the ear, Spanish. A maverick; a long-eared calf.

Outiaw.-(In Spanish a "Cimarron.") A range animal that does not travel nor associate with others of its kind.

Over Ifnlf Crop, Upper llalf Crop.-The upper or lower half of the ear is taken off at a point about half way to the head.

ox.-Generally applied to work cattle. Correctly a steer that works in yoke or collar. Both bulls and steers are used for work purposes.

Palomlllo, Inlomlno.-(Mexican.) A cream-colored horse, a buckskin.

Parrot-mouthed Horse-A horse whose front teeth, generally through age but not always, project unusually far forward beyond the jaws. "Buck-toothed," like the beak of a parrot; hence "parrot-mouth."

Pelon.-(Pay-loan.) A mulley animal; hornless; from spanish, bald.

Reata.-Same as lasso. Generally made of rawhide.

Remuda.-(Spanish). Remounts, exchange horses, saddle horses. The horse herd with a roundup.

Ridgling. - A male horse one or both of whose testicles have not "come down" where they can be reached for castration. Such animals can serve mares. As their testicles are very hard to find, the castrating operation should be performed by some one well acquainted with the work. Frequently called an "original," also "ridgal."

Shrinkage.-The reduction in welght allowed the buyer in receiving cattle fresh from the range or pasture. A 3 per cent reduction or an over-night's stand in the corral without feed or water is generally considered a fair allowance to each side.

Side Winder, Steru Wheeler.-A pacing saddle horse.

Single IRIg Saddle.-A " center fire" saddle; saddle with one cinch.

sit-fnst.-A hard callous place that comes upon a horse's back where there has been a saddle sore.

sleeper.-A calf that has been marked but not branded. Thls is a favorite trick of the cattle rustler who finds on the range a large unbranded calf following its mother. The cow belongs to some one else. The rustler catches the calf and places the owner's ear-mark on it but does not brand it. Such a calf is very likely to be overlooked in a big roundup, and if it is and becomes weaned the rustler who has kept his eye on it ropes it again, cuts out the ear-mark and places hls brand on the calf.

Sprlnger.-Market name for a milk cow about ready to calve.

Squeeze Chute, Branding Chute, Snapplng Turtle.-A place where animals are forced through a narrow passage-way until they reach the end, when the side is drawn against them, holding them securely while they are branded or dehorned. Called a "snapping turtle" when the holding arrangement is a heavy pole or timber which works on a hinge at the bottom and by means of a rope running from the top over a pulley is drawn against and just in front of the hip bones, holding them securely while the operation is performed. 
Stag.-A male animal that was not castrated until late in llfe.

stallon.-A male of the equine species. Often called an "entire" horse.

Steer.-A castrated male of the bovine specles.

Swallow Fork.-A V-shaped plece taken out of the point of the ear.

Swaybacks.-Animals whose backs are unusually bent or swayed. A sign of physical weakness.

Tapaderos, Taps.-Heavy leather covers or hoods to go over stirrups of saddle.

The Drags.-Those animals that are found at the tall end of the herd as it travels.

Under BIt, Over Blt.-A V-shaped piece taken out of the lower or upper part of the ear.

Varruga.-(Spanish.) Wattle. A distinguishing mark for both sheep and cattle made by cutting a strip of hide down about 2 inches, allowing it to hang like a tassel or wattle. Usually made on the cheeks or necks.

Vega-Spanish for meadow; also a rafter in an adobe house.

Wet Band, Lamb Rand.-Ewes whose lambs are old enough to follow their mothers on the range.

Wether.-A castrated male sheep.

Wrnngler.-The horse herder for a roundup outfit. 


\section{INDEX.}

Aberderin-Angus catíle, 95.

Aconite, 264 . called monk's hood, 268 .

Age of live stock, $\mathbf{1 6 9}$.

Albuquerque, New Mexico, loco growth near, 258.

Alfalfa, 253 .

causes bloat, 252 .

killing out, 245.

Alfileria, 39,65 .

origin of, 72 .

Angora kids, staking system, 162.

nuttou, 111 .

venison, 111.

Aparejo, 365.

Arizona, cost of handling sheep, 200.

loco in, 262 .

loco year in, 259 .

Merino sheep in, 104.

Azoturia, 311.

symptoms and remedies, 314.

Aztec Cattle Co., 115.

Baits, poison, how to prepare, 338 .

Baking soda, use of, 249,254 , 274.

Basco hitch, 370 .

Bears, not dangerous to stock, 334.

Bed ground, use of, 173.

Bell Ranch in New Mexico, 114.

Bermuda grass, 49 .

Big jaw, symptoms and remedies, 286.

Bits, riding, 358 .

Black bunch grass, 43.

Black grama grass, 49.

Black leg, 286 .

symptoms and remedies, 288 .

veccination against, 293.

Plankets, saddle, 359.

Blanket weaving, 102.

Bleeding of stock unwise, 249.

Blind teeth of horse, 283 .

Bloat, $249,286$.

how caused, 252.

symptoms and remedies, 252 . $254,274$.

Bloating in larkspur, 276.

Blue grama grass, 49.

Rlue grass, Kentucky, 70 .

Blue ioint grass, identification of, 65.

B? ue stem grass, $61,70,270$. identification of, 65 .
Bog rider, the, 120 .

Bogging of cattle, 122.

Boots, high heeled, I18.

liot fly, 283, 323 .

liot fly' (see heel flies).

Bots, no such disease, 283.

Brands, altering of, 196.

Bland books, I86, 187, 189, 190 , I91.

Branding calves, 129.

Branding fluid, A ustralian, 181.

Brand inspectors, 134 .

Brands, names of various characters, 192.

picking of, 198 .

specimen of, 192 .

Bridles, riding, $35 \mathrm{~s}$.

Brine, used for pinguc, 280.

Broken-mouthed ewes, 172. sheep, 201.

Brome grass, 242, 265.

Bronco grass, 72 .

Buck brush, 61,65 .

Bucks, handling of, 155.

time to place with ewes, 155. when too old, 202.

Buffalo grass, $49,65$. how recognized, 49. herds, 24.

Bulls, dehorning of, 180 . number required, 179. on range, 179. question of age, 179 .

Bunch grass, 43 .

13urning over a range, 226 .

Button sage, 63 .

California sheep ranges, 104 , $2 \mathrm{I} 4$.

Calves, dehorning of, 180 .

Camp rustler, 157. tender, 157 .

Canula, use of, 255.

Carrying capacity of ranges, 77 .

Castrating, 183. lambs, 151.

Catclaw, 39 .

Cattle and sheep, grazing ratlo between, 78 .

determining age of, 164.

diseases, 286 .

Chamiza, 21, 61 .

Changing class of stock, 214.

"Chaps," 118.

Chloral hydrate, use of, 278, 313.

Chloroform, use of, 322 .

Choke cherry, leaves kill sheep, 248 . 
Choke chel'y", losses from, 271. poisoning, symptoms and remedies, 280.

Chuck wagon, the, $116,125$.

Chutes for branding, 130 .

Climatic changes, $\$ 5$.

Close grazing, 244.

of ranges, 236,238 .

Colic, remedy for, 311 .

various kinds of, 311 .

Colorado, average shearing of sheep, 206.

Coming of the settler, 81 .

Control of Government ranges, bill for, 377 .

Coronado's expedition, 97.

Corn smut, 246.

Cost, of running sheep, 200.

of running stock, 199.

Cotswold sheep, 106.

Cow bane (see water hemlock), 267.

Coyotes, in California, 329.

killing of, 327 .

Crow Creek reservation, 222.

Cud, failure to chew, 283 .

Cups in teeth, 169.

Curly mesquite grass, 43,49 .

Curtailment of the open range, 31.

Cutting out cattle, 129.

Death camas, $247,248,266$. poisoning, remedies for, 277 . valieties of, 267.

Deer flies, 325 .

Definitions, 380 .

Dehorning cattle, 180.

Delaine sheep, 106.

Desert range, 40 .

Developing water in quick sands, 123 .

Devons, the, 92 .

Diamond hitch, 368 .

Dipping sheep, 149,306 .

Diseases, of cattle, book on, 284.

of horses, book on, 284 .

Docking lambs, 151.

Dog-town grass, 43.

Double-wintered steers, 34 .

"Downers," 136.

Drags, how to use, 338 .

Drenches, use of, 284 .

Drop band, the, 153 .

Dry farmers, the 89.

limits to advance, 116. success of, 90 .

Ear marking, 183.

Ear marks on horses, 184.

Early horses of the plains, 97.

Early settlers of the plains, 82 , $84,226$.

England, cost of raising sheep, 207.

Epsom salts, use of, 312 .
Era of readjustment, 26 .

Erosion due to stock trails, 228 .

Ergot, losses from, 270. poisoning, symptoms remedies, 279 .

Esta-fi-etta, 57 .

Ewes, broken-mouthed, 172.

Fye teeth of horse, 283 .

Farcy (see glanders), 316.

Fenced enclosures for raising sheep, 160 .

File weed, 236.

Flies, protecting horses from, 325 .

Foot rot, among sheep, 304.

Forest Iiangers, 213.

Forest Service, example of system, 234.

success of, 233 .

vs. sheep men, 215.

Fort Collins lamb feeding, 36 .

Iowler's solution, use of, 275 .

Foxtail grass, 72, 246, 272 .

Galleta grass, $43,49$.

Galloway cattle, 96 .

Geranium, wild, 264

Glanders in horses, 316.

Goats, 79.

Angoras, 108, 161.

Angoras, handling of, 161.

Angoras, kids very tender, 161.

Angoras, shearing average, 111.

Angoras, shipment from South Africa prohibited, 109.

Angoras, shipment from Tur key prohibited, 109.

common breed best, 163 .

dipping, 163.

Mexican, 107.

shearing, 163 .

trained to load sheep, 156

Government control of grazing: lands, $29,233$.

ranges, destruction of, 233 .

rules for handling stock, 173.

Grama grass, 43, 49.

Grease wood, 57.

Grass, burning of, 226.

Grasses, destruction of, 236 .

of the southern jange, 38 .

Grazing lands, railroad, 202 .

Grazing on public lands, bill for control of, 377 .

Hair ropes, spinning of, 119.

Hampshire sheep, 106.

Hay, black grama, 50 .

fed cattle, 138 .

hoe-cut, 50 .

rule for measuring, 138.

Heel flies, 323 .

Hemlock poisoning, 250 . 
Herders, monthly cost of provisions, 205.

Herds, size of, 126.

Hereford cattle, 93.

Higher ranges of the southwest, 43.

Hitches, packing, 368 . the Basco, 370.

Hobbled horses, how to approach, 124.

Hobbles, how made, 363 . use of, 362 .

Hogs, branding and ear marking, 112.

objection to on ranges, 112. on the ranges, 111.

llollow horn, 284.

Hopples (see hobbles), 362 .

Horn flies, history of, 320 .

Horns, buttons on, 167. of cattle, telling age by, 167 . rings upon, 167.

Horse, cups in teeth, 169 determining age of, 169

Horses, diseases of, 310. hard on ranges, 77 .

Hutchinson, Kansas, 85 .

Indian reservations, charge for stock upon, $200,221$.

Indians skinning cattle, 123.

Insect pests, 320 .

Iodide of potassium, use of, 287.

Jack rabbits devoured by coyotes, 329 .

Johnson grass, 65.

Kafir corn poisoning, danger of, 280.

Kansas, prairie dogs in, 343 .

Kemp, description of, 110 .

Kentucky blue grass, 70 .

Kyaks, 370,374 .

Lamb erop, average of, 144 .

Lamb feeding, 141.

Lambing, critical period, 154. grounds, $73,150,225$.

in tents, 153.

tine of, 149.

Lambs, care of, 151.

castrating, 151 .

docking, 151.

increase of, 205 .

marking, 151.

prices paid for, 142 .

weight of, 154 .

Lampass, cure for, 283 .

Lands, exchanging use of, 223 .

Lard, use of, $249,278,279$.

Large cattle outfits, 114.

Larkspur, 248.

eradification of, 265 .

losses from, 264.

purple, 264.

symptoms and remedies, 276.
Larkspur, tall, 264.

Lash rope, length of, 374

Leasing of grazing lands, 143.

Lime and sulphur dip, 307.

Lillsted oil, use of, 312 .

Lip and leg ulceration, symptoms and remedies, 308.

Livestock, diseases of, 282. number of, 91 .

Loading stock on ears, 135.

Lobelia, sometimes taken for camas, 266 .

Loco, area covered by plant, 256.

remedies, $250,263,275$.

silvery, 265 .

symptoms, 260 .

years, 258 .

Locoed animals easily drowned, 262 .

horses, peculiarities of, 262.

mule, story of, 261 .

Long horn cattle, 92.

Lupine causes bloat, 252 .

dry seeds of deadly, 266 .

elimination of 266 .

lay, 266 .

identification of, 265 .

poisoning, symptoms and remedies, 277 .

lump jaw (see big jaw), 286.

Lynxes, 330 .

Mallein test for glanders, 319.

Nallow, red false, 264 .

Magnesium sulphate, use of, 275 .

Mange among horses, 303 .

in cattle, 298 .

Manti National Forest, 210.

Marking lambs, 151. stock by tattoo process. 182.

Marsh, Prof. C. D., 263, 275, 276.

Matador Cattle Co., 114.

Maximum limits, meaning of, 217.

Meadows, damage of, 230 . hay, 244 . reseeding of, 242 .

Merino foundation desirable, 106.

Merino sheep, 104, 106.

Mesquite beans, 38 .

Mexican sheep herders, 203

Milling of eattle, 132 .

Mistletoe, feeding of, 58 .

Mohair, length of, 110 . value of 110.

Monk's hood (see aconite), 268.

Montana cost of grazing sheep, 200 .

herders required, 204 .

Mormons, $87,92$.

coming of, 84.

expedition, 22 .

Morphine, use of, $278,313$. 
Motherless calves, 88 .

Mountain bunch grass, 70 . forage, 61 .

lion, best bait for, 339 .

lions, hard to trap, 331 .

mahogany, $43,61,65$.

meadows, 70 .

parks, 66.

Moving ewes and lambs to mountains, 154.

Mules, killing young stock, 78 .

Mustangs, $98,99$.

Mutton eating in America, 106. sheep, hard to herd, 106. type of sheep, 106.

National Forests, cattle vs. sheep, 215.

competitive bids for use of, 221 .

exchange of land, 223 .

fencing privileges, 219.

free grazing on, 211.

grazing fees low, 220 .

grazing fees on, 200.

Government not forced to

fence, 219 .

improvement of ranges, 212.

lambs grazed free, 225 .

livestock upon, $20 \mathrm{~S}$.

number of stock upon, 224.

permits for more than one year, 219.

permit system on, 216.

policy liberal, 211.

private lands in, 223 .

protective and maximum limits, 217.

purchase of stock using, 218 .

ranges, comparison of fees, 221.

reductions in numbers, 217.

stock losses in, 224 .

stock permits not salable, 218.

use of by stockmen, 209.

value of permits, 218 .

Navajo blankets, 102 .

Indians as sheep owners, 103.

Needle grass, $43,246$.

Neighbors not desired, 82 .

Nesters, the, 87.

New Mexico, cost of grazing sheep, 200.

introduction of sheep into, 103 .

loco in, 260 .

pastures, charges for, 199.

sheep herders required, 204.

Night herding, 131.

of sheep, 152 .

North Park, Colorado, 66.

Northern range, 33,64 .

Oak poisoning, stock losses from, 268 .
Oak poisoning, symptoms and remedies, $269,278$.

Ohio, cost of raising sheep, 206.

Oil, linseed, use of, 279 .

Orchard grass, $242,265$.

Oregon wind, 368 .

Overgrazing, 244.

Overstocking, damage from, 231.

Pack pockets, $370,374$.

Pack saddles, 365 .

saw buck type, 366 .

Packing, 365 .

Pacing horses, peculiarities of, 350 .

Panhandle of Texas, $\$ 9$.

Parsnip, wild (see water hem$10 \mathrm{ck}), 267$.

Paunching, 254, 274.

how accomplished, 255.

Pea rine (see lupine), 265.

Per capita systern of grazing, 216.

Permanganate of potash, use of, $250,269,277,279$.

Permit system on National Forests, 216.

Pike, Captain, 97.

Pingue plant, losses from, 269. poisoning, symptoms and remedies, 280 .

Poisoning predatory animals, 335.

Poisonous plants, choking out, 242.

do animals know them, 246.

losses from, 246.

injurious to sheep, 247.

symptoms and remedies, 249 , 274.

Polled Angus cattle, 95.

Porcupine grass, 43, 246.

Poverty grass, 72.

Prairie dog grass, 343.

Prairie dogs and rattlesnakes, 340 .

damage to range from, 339 .

digging to water, 340 .

grass destroyed by, 343 .

poison, how placed, 346 .

preparing poison for, 344.

Prairie June grass, 64.

Predatory animals, 224. losses from, 327 .

Prickly pear, feeding of, 57 . spineless variety, 58 .

Private lands in National Forests, 223 .

Protective limits, 217.

Prussic acid in kafir corn and sorghum, 280.

Public ranges, bill for control of, 377 .

Pueblo Indians, 102. 
Quick sand, 123.

Quinine bush, 61 .

Quirts, 119, 361.

Rambouillet sheep, 106.

liams (see bucks), 155.

liange, conditions past and present, 116

horses, 97.

methods, 124.

wars, 27.

lianges, carrying capacity, 232 . close grazing of, 236.

rotation system, 238 .

Tattlesnakes in prairic dog holes, 340 .

Reclamation service, 210 .

red desert, the, 61, 143 .

Red-top grass, 242 .

Reseeding, harrowing land, 243 . ranges, 238 . use of sheep in, 243 .

Restoring original condlions, 235.

Riatas, 119.

Roosevelt dam, 210.

Fope, how to use, 360 . on saddle, 360 .

tied to horn, 361 .

Rotation system, 238.

Round-up herds, size of, 126. outfit, work of, 124.

Rubber weed, 269.

Running irons, 198 .

liussian thistle, 63 .

liye glass, 242 . wild, 270.

Sacaton, $5 \ddot{4}$

Sildle blankets, 359.

hor'se, gaiting, 350 .

horses, gaits of, 349 .

history of American, 354.

how to mount, 351 .

selection of, 350 .

sore backed, 360 .

tricks in riding, 353 .

Saddles, double rigged, 356 .

McClellan, 355.

pack, 365 .

Texas, 356 .

types of, 348,355 .

Sages, 57 .

Sialt and sulphur for stock, 174.

danger of using, 175.

hungry stock, 177.

kind to use, 174.

lakes, 175 .

licks, 174 .

lick, maliing of, 176 .

petre, drench, $\mathbf{3 1 5}$.

petre, use of, 28 .

rock, making sore tongues, 176.

rock vs. fine, 175 .

sage, 57,63 .
Salting stock, 174, 178.

siample attack, 28 .

Santa Fe, railroad, old trails along, 229

trail, 230 .

San Joaquin Plains, 72.

Scabies, dipping cattle for, 300 . in cattle, 298. spraying cattle for. 301 .

Scents, how made, 337 .

Screw worms, danger from, 321. tlies, 321.

Serub oak, 268.

injurious to cattle, 61 .

stock losses from, 268.

Seeds, how to test, 244.

Siervice berry, 65.

Settlers, majority cattle raisers, 216.

second attack. on arid region, 85.

Sex, keeping track of in branding, 184 .

Shad scalc, 57,63 .

Shearing, blankets for sheep after, 147. time of, 147.

Sheep, avelage weight of fleece, 205.

bedding down at night, 158. coarse wooled, 106.

cost of raising, $203,205$.

cost of running, 206 .

deterioration of, 201.

determining age of, 172 .

dipping, cost of, 307.

dips, for killing screw worms, 322

diseases of 304

double profit from, 144.

first in United States, 100.

goats used in loading, 156.

grazing, value of, 214 .

herders, average number "of sheep to each, 205.

herders, wages paid, 204.

herder, work of, 150 .

increased cost of production. 143.

in fenced enclosures, 160 .

loading in cars, 156 .

loss from bloat, 253 .

maintenance cost, 206 .

men, advent of, 26 .

men, find fault, 211.

on range, handling of, 140 .

open wooled, 107, 140.

percentage of increase, 144, 211.

ranch, investment for, 202 .

report of Tariff Board, 203.

scab among, 304 .

seab, dipping for, 306 .

scab, doctoring for, 306 .

scab, in Bible, 305.

scab, remedies, 306 . 
Sheep scab, work of Government in controlling, 306 .

shearing by hand, 143.

shearing by machine, 143 .

size of bands, $156,157$.

teeth of, 172 .

value per head, 205.

versus cattle, 215 .

water for, 154 .

Shin oak, 268 .

Shinneries, 268.

Shipping sheep, 156. stock, 136 .

Short-horns on the range, 91.

Shropshire sheep, 106.

Sleepy grass, peculiarities of, 272 .

Small stock owners, position of, 234 .

Snake bites, symptoms and remedies, 315 .

Snake weed, 236.

Sneeze weed, injurious to sheep, 271.

poisoning, symptoms and remedies, 279.

water poisoned by, 271.

Silver City, New Mexico, good goat region, 109 .

Single-wintered steers, 33 .

Sorghum, 65.

poisoning, danger of, 280 .

Southern lamb trade, 36.

range, 33 .

steer trade, 33.

South Palk, Colorado, 66.

Southwestern grasses, 49.

Spade bits, 119, 358.

Spanish bayonet, $39,49$. ring bit, 358 .

Spring ranges, 72 .

Spurs and quirts, 361.

Squeeze chutes, 130.

Squirrel tail grass, 272 .

Staked plains, origin of name. 49.

Stampedes, 132.

State lands, use of, 222, 223.

stock cars, number of animals to a load, 136.

Stock, driveways, 213.

Government rules for handling, 173.

medicines, how given, 284.

number of National Forests, 224 .

ranges, Government control of, 233 .

Stocking the ranges, $\$ 2$.

Strawberry Valley Project, 202, 222 .

Strychnine, use of, $250,275,338$. Success of the settlers, 86.

Sulphur for stock, 174.

Supra-orbits in horses, 169.

Swamp camas, 267 .
Sweet sage, 57 .

Teeth, telling age of stock by, 164.

Tennessee Pass of Colorado, 66 .

Texas fever, history of, 294.

losses from, 296.

pastures, charges for, 200 .

quarantine against, 297 .

tick, how to recognize, 298.

ticks, life history of, 297 .

Ticks, Texas fever, 294.

Timothy, 61, 242.

Tonto Basin War, 27.

Trails, cattle and sheep, 228.

Tramp stockmen, 214.

Traps, steel, how to set, 336 .

Trocar, use of, 255.

Trapping predatory animals, 335.

Tumble weed, 63.

Turpentine, use in colic, 313.

Twins among stock, 147.

Two years before the mast, 22.

Utah state lands, 222.

Veterinary surgeon, shouid be called, 282.

Warble flies, 323 .

Warbles, in cattle, 324.

life history of, 324 .

losses to stockmen from, 325 .

Washington, average shearing of sheep, 206.

Water, for stock, 79 .

hemlock, description of, 267 . hemlock, poisoning, symptoms and remedies, 277.

sheep need little, 154 .

Weeds eaten by sheep, 80 .

Western wheat grass, 65.

Wheat grass, 64,70 .

White bunch grass, 61 .

White clover, 70 .

Wild cats, losses from, 330 . oats, 61 .

pea (see lupine), 265. rye, 61 .

IVind colic, 312 .

Winter fat, 57 .

Wolfbane (see aconite). 26is.

Wolfers, employment of, 332 .

II olf tail, 284.

Wolves, characteristics of, 330 losses from, 327 . poisoning of, 333 . size of litter, 334 .

Tirooden tongue, 286.

Wool, advance in prices, 142. average weight of clip, 148 , 205.

cost of production, 206.

Wrong use of names, 99.

Yucca, 43.

Zuni, pueblo of, 100. 



University of British Columbia Library DATE DUE

\begin{tabular}{|c|c|c|c|}
\hline ANQ I & 895 & 201 & 9 TES? \\
\hline$m=1$ & 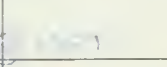 & $D E C$ & 171974 \\
\hline LEL 19 & 1961 & DEC & 16 REपा \\
\hline 0671 & (1) 1962 & SEP & 89197 \\
\hline OCT & 261562 & $\begin{array}{l}\text { SEP } 1 \\
\text { SEP }=?\end{array}$ & $\frac{6}{2.9-15 \sqrt{3}}$ \\
\hline $\begin{array}{l}\text { NOV } 1 \\
\end{array}$ & $\frac{24}{171966}$ & EEf 17 & fieste \\
\hline NuY & 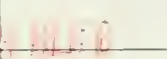 & 0156 & d. . . \\
\hline & & LE & . \\
\hline & & OCT 7 & -1970 \\
\hline WoV & 1868 & $\sqrt{61} \mathrm{~B}$ & T. Rete \\
\hline & & & \\
\hline . & & & \\
\hline $2+15 y$ & & & \\
\hline$y$. & & & \\
\hline
\end{tabular}

101-40M-4-58. V.S. 
AGRICUILTURE

A.GR!CULT,URE -

FORESTRY

L!BRARY
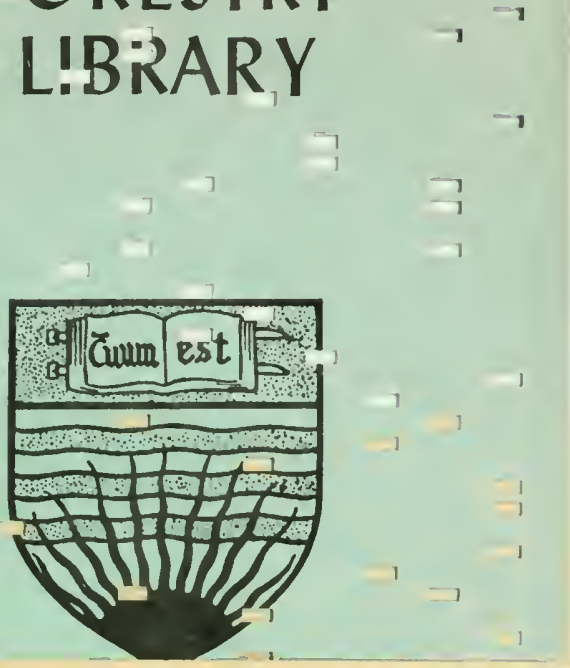
(1)

16) Whing

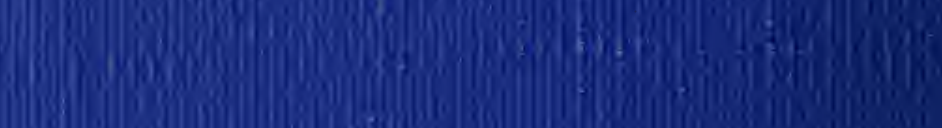

(1)

1119

FI

ion

Ro.

$3(\mid-1)$.

(1)

gom

I.

5.

If

ab.

fos.

H.

9.

(3) $3(90)$

(1) 1 ||

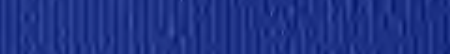

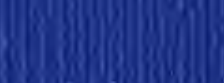

(1) 